
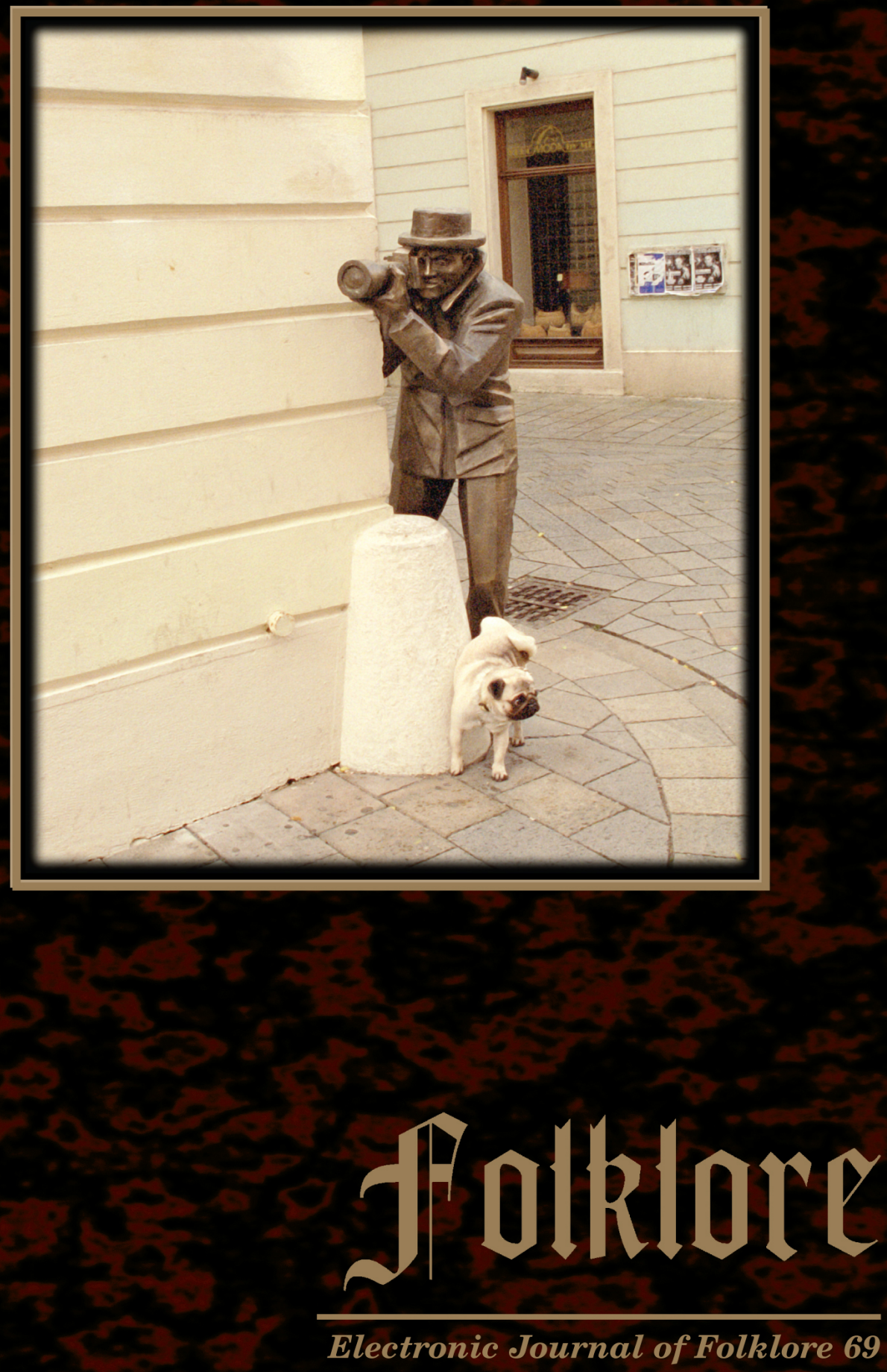


\section{Folklore}

Electronic Journal of Folklore

http://www.folklore.ee/folklore Printed version

Vol. 69

2017 
Folk Belief and Media Group

of the Estonian Literary Museum

Estonian Institute of Folklore

\section{Folklore}

Electronic Journal of Folklore

Vol. 69

Edited by Mare Kõiva \& Andres Kuperjanov

Guest editor: Eda Kalmre

ELM Scholarly Press

Tartu 2017 
Editor in chief

Co-editor

Guest editor

Copy editor

News and reviews

Design

Layout
Mare Kõiva

Andres Kuperjanov

Eda Kalmre

Tiina Mällo

Piret Voolaid

Andres Kuperjanov

Diana Kahre

Editorial board 2015-2020: Dan Ben-Amos (University of Pennsylvania, USA), Larisa Fialkova (University of Haifa, Israel), Diane Goldstein (Indiana University, USA), Terry Gunnell (University of Iceland), Jawaharlal Handoo (University of Mysore, India), Frank Korom (Boston University, USA), Jurij Fikfak (Institute of Slovenian Ethnology), Ülo Valk (University of Tartu, Estonia), Wolfgang Mieder (University of Vermont, USA), Irina Sedakova (Russian Academy of Sciences).

This issue is dedicated to the 70th anniversary of the Department of Folkloristics of the Estonian Literary Museum.

The journal is supported by the Estonian Ministry of Education and Research (IUT 22-5), the European Union through the European Regional Development Fund (Centre of Excellence in Estonian Studies), the state programme project EKKM14-344, and the Estonian Literary Museum.

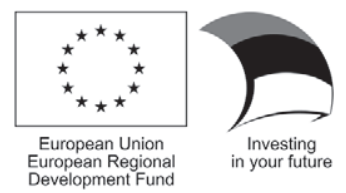

Indexed in EBSCO Publishing Humanities International Complete, Thomson Reuters Arts \& Humanities Citation Index, MLA International Bibliography, Ulrich's Periodicals Directory, Internationale Volkskundliche Bibliographie / International Folklore Bibliography / Bibliographie Internationale d'Ethnologie, Open Folklore, C.E.E.O.L., Scopus

\section{Editorial address:}

Folklore: Electronic Journal of Folklore

Vanemuise 42-235

51003 Tartu

Estonia

phone: $\quad+3727377740$

fax: $\quad+3727377706$

e-mail:_folklore@folklore.ee

home page: http://www.folklore.ee/folklore

All rights reserved

(C) Estonian Literary Museum

Estonian Institute of Folklore

Authors

Design Andres Kuperjanov

According to Creative Commons licence BY-NC-ND 4.0

ISSN 1406-0957

doi:10.7592/FEJF2017.69 


\section{CONTENTS}

Introduction: The Social and Political Dynamic

of Conspiracy Theories, Rumours, Fake News, and

Belief Narratives

Eda Kalmre

Rumor, Humor, and Other Forms of Election Folklore

in Non-Democratic Societies: The Case of Belarus

Anastasiya Astapova

The Image of the West in Conspiracy Theories in Slovakia and

Its Historical Context

Zuzana Panczová

The Beast Computer in Brussels: Religion, Conspiracy Theories, and Contemporary Legends in Post-Soviet Culture

Alexander Panchenko

Rumour and Humour in \#WhereIsPutin and \#PutinUmer:

Global Media and the Cult of Putin

Liisi Laineste, Eda Kalmre

Women-Snipers from Chechnya to Ukraine:

A Post-Soviet War Legend

Amandine Regamey

Representation of the Snowden Scandal in the Estonian Media:

The Construction of Threats and Fear

Mari-Liis Madisson

From the Editorial Board

Zeroing in on Performance 2.0: From Serialization

to Performative Enactments

Antti Lindfors 
Riddles and Humour

Annikki Kaivola-Bregenhøj

NEws IN BRIEF

Scientific Symposium on Folklore Heroes. Saša Babič

Folklore and the Public: Estonian Folklorists' 12th Winter Conference.

Katre Kikas

212

Cultural Scholars Gathered in Tartu. Liisi Laineste

Book Review

Mutual Interaction of Tourism and Cultural Heritage on the Example of Dracula Lore. Reet Hiiemäe 


\title{
INTRODUCTION: \\ THE SOCIAL AND POLITICAL DYNAMIC OF CONSPIRACY THEORIES, RUMOURS, FAKE NEWS, AND BELIEF NARRATIVES
}

\author{
Eda Kalmre \\ Department of Folkloristics \\ Estonian Literary Museum, Estonia \\ e-mail:eda@folklore.ee
}

This special issue of journal Folklore: Electronic Journal of Folklore focuses on the research of conspiracy theories, contemporary legends, and rumours sets of ideas and practices, their spread, consistence, and models, spreading as newslore, fake news, and communication styles - which strongly influence today's society and often create insecurity. The potential of this material as an influencer of human thinking and history, of political and cultural values and illusions, is big. Rumours and their related genre, legends, have a significant role in today's social and everyday communication. Articles presented here proceed from these two genres as cultural matrixes, by means of which folkloristics and its neighbouring fields can study creativity and the complexity of human speech acts throughout history, cultures, and numerous determined and undetermined circumstances (Harris-Lopes 2003; Fine 1997).

Rumours have been defined as transmitters of suspicious information or beliefs, which represent society's peripheral side and the prejudices hidden therein (Allport \& Postman 1947; Anderson 1926; Shibutani 1966; Kapferer 1990; Neubauer 1999; etc.). The study of some rumours and legends in Estonia allows us to realise the potential of folklore to influence people's thinking, behaviour, memories, and even history. These legends and rumours represent different political and cultural values, illusions, and hopes on personal and community levels (Kalmre 2013a, 2013b; see also Turner 1993; Fine \& Turner 2001 ; etc.). Rumours and legends can be part of a person's or even nation's identity creation process (Kalmre 2005, 2013b; Møllegaard 2005), and they can be used as mechanisms of attack, offense or subjective protection. 
One of the important features of rumours and legends is that "they are told as true, factual, or plausible and therefore assume a level of authority; they provoke dialogue about the narrative events, their interpretation, and their plausibility; they both articulate and influence beliefs and attitudes towards the subject matter; and they have the capability of affecting the actions and behaviour of the listening audience" (Goldstein 2004: 28). Indeed, the majority of these traditional texts affect us one way or another and call us to express our opinion, discuss and debate, and thus inevitably have an impact on our collective consciousness.

By reflecting the community's collective values, these narratives interpret reality in their own way, and often have political nature. They are based on transmitting dialectical tensions of the community, focusing on the norms, values, and expectations of concrete cultural groups. On the other hand, there is nothing static in the prejudices and beliefs in these narratives. Transmitting the truth inherent in these narratives should be viewed as a process characterised by a constant discussion about different cultural ideologies (Tangherlini 2007; Valk 2008, etc.).

Today beliefs and ideas often spread in the form of negatory rumours, resulting in various conspiracy theories (Barkun 2003; Madisson 2014). A characteristic feature of negatory rumours and legends is hypercritical thinking, which is expressed in strong suspicion, in considering real-life events as rumours, and in exposing them as another reality. It means that each negatory rumour is coupled with an assertive rumour, replacing the denied reality with a new reality. Yet, it is difficult to provide evidence for this other reality, and this is not because this other reality is an illusion, but because proofs are systematically suppressed or hidden, as adherents of negatory ideas claim (cf. Renard 2005). Sketching an immoral, malignant, and very powerful enemy, acting undercover, makes it possible to present the interpreter's own views as something ethical, transparent, and justified (Madisson 2016).

In today's social life, the influence of written and spoken text on human thinking and opinions is stronger than in the pre-Internet era. Therefore, the present study of fake news, rumours, legends, and conspiracy theories also involves the study of the media in its original performance. Researchers have often struggled with how to record short-lived rumours that are passed on by word of mouth, and have found it even more difficult to trace the origin and development of the hearsay; today the Internet with its social media, digital journalism, and search engines greatly facilitates the process (Blank 2007, 2009; Shifman 2007). The internet communication environment where rumours, belief messages or longer belief narratives (legends) multiply and spread like 
lightening across many channels validates this belief and expands the circle of believers (Barkun 2003). The newslore assuming different forms around a concrete alarming rumour or a scandal - jokes, urban legends, parodies, fake news, digitally processed photographs, political and commercial announcements, etc. - allows for observing the whole similar discourse in the operational practices of today's media (Frank 2011).

The dynamic of rumours, fake news, and belief stories in oral communication, on the Internet, in the media, and in today's culture in a wider sense is related not only to the truth and power on the personal and collective level, but also to propaganda and politics on the state level (Astapova 2015; Regamey 2011; Kalmre 2013a).

Power plays a crucial role in written discourse because it controls the social beliefs, attitudes, and behaviours of people of any society or group (Nycyk 2015; van Dijk 2001). These can occur in any documents, but particularly so on the Internet. Power is a complex strategically driven phenomenon produced through social interaction from many directions and by human actors, often resulting in the maintenance of inequitable social relations (Foucault 1980, 1981). People use it in specific ways in social situations to control outcomes, and as a persuasive device through the use of language to cause the inequality and marginalisation of others. Gossiping and spreading rumours are types of power tactics used on the Internet, particularly social media sites such as Facebook and Twitter, to persuade others to believe information about themselves or others.

The idea of a special issue of journal Folklore dedicated to rumours, contemporary legends, and conspiracy theories was born at the end of 2015, half a year before the conference of the International Society of Contemporary Legend Research in Tallinn. This society, established in 1988 and dedicated to the study of contemporary legends and rumours, today unites folklorists, social scientists, journalists, and psychologist from all over the world, and organises annual conferences. Unfortunately, the idea of a special issue was not realised before the conference in the summer of 2016. But I am glad to say that two articles of this issue were written on the basis of presentations made at the Tallinn conference.

The first one is Anastasiya Astapova's article about presidential election folklore in Belarus. Belarus is a non-democratic country and the results of the elections are known in advance. But at the same time, the election rumours and jokes circulating in the oral communication and on the Internet question the existing hegemony. Anastasiya Astapova shows, based on her fieldwork examples, how the genres of rumours and jokes are interconnected, sometimes 
to the point of being indiscernible. Belarusian elections folklore has become so widespread and creative that its genres intermingle to the extent that it is impossible to tell one from another; they move from one election to the next whether through oral communication, news, or the Internet.

Another participant in the Tallinn conference, Zuzana Panczová, presents in her article one of the typical features of conspiracy theories - a dualistic worldview, which explains important events as a consequence of a hidden struggle between 'Us' and the dark forces. An example of this characteristic also presents the dichotomous terms 'West' and 'East'. As a political and moral concept, the 'West' is very much used in the conspiratorial discourse in Slovakia. The author points out the functions of this concept as an 'enemy' in rumours and conspiracy theories. Her sources of research include the mass media, internet discussions, and social networks. The author shows that in Slovakia the negative image of the West is based on historical memory, which has been passed on from one generation to another, used by the propaganda of different political regimes, and supported by the authority of important personalities in the Slovak national history.

Alexander Panchenko's article deals with the role of conspiratorial motifs and themes in the formation and transmission of what is known as 'contemporary legend'. The discussion of empirical data focuses on apocalyptic narratives about 'the Beast of Brussels'. The author shows how and why the present-day conspiracy theories and practices of 'conspiratorial hermeneutics' are inspired by particular combinations of emotional, moral, and epistemological expectations.

Eda Kalmre and Liisi Laineste write about the cult of president Putin and the media behaviour related to the recent rumours concerning Putin's disappearance from the public eye during a ten-day period in March 2015. The data analysed here consist of two equally important sources: global news coverage of Putin's disappearance, and the information spread in social media via Twitter hashtags \#WhereIsPutin and \#PutinUmer. The authors describe how the news spread on the global arena, what the differences are between English- and Russian-language social media sources; what the reoccurring and more influential belief motives are in the stories told about the political leaders in Russia, and how they reappear in present-day internet folklore, especially humour. The analysis sheds light on the inner workings of rumour and humour in social media and its effect on the dissemination and content of folklore.

Amandine Regamey writes about a very influential story, a rumour and contemporary legend, which accompanies all military conflicts provoked by Russia. The rumour surfaces once again in Ukraine. It talks about womensnipers, former biathlon champions from the Baltic states, who allegedly fought 
alongside Chechen militants or in the military forces of Ukraine more than ten years later. The article explores the different aspects of a war legend that was born among soldiers, was embodied in fiction and popular culture, and was used in Russian official propaganda. It shows that the focus on Baltic mercenaries allows for presenting Russia simultaneously as the successor of the Soviet Union fighting against fascism, and as a state besieged by Islamic terrorism and American expansionism.

Mari-Liis Madisson in her article "Representation of Snowden's scandal in the Estonian media: The construction of threats and fear" explicates how the leakages concerning the details of the top-secret United States government mass surveillance programme PRISM were contextualised in the Estonian public information space. The Snowden affair received strong public feedback because this topic addressed even those people who had normally kept their distance from politics. It touched the cornerstone of contemporary identities the right for free Internet. The Internet is frequently associated with the freedom of expression, horizontal relations between citizens and state authorities, transparent governing, etc., and those characteristics are often interpreted as signs of the progressive and democratic nature of the medium. This study tries to explain how such positive connotations start to resonate with cultural fears of unregulated surveillance and non-transparent control.

In conclusion it could be mentioned that, although not planned in the beginning, this issue became more focused on the Eastern material. I sincerely hope that it offers the readers excitement and new ideas as well as thoughts for further discussions, as similar studies on the connections between rumours, legends, and conspiracy theories as well as humour and belief stories in the former Soviet Union and Eastern Europe have not been published extensively. Finally, I would like to thank all the authors for their contributions and good collaboration.

\section{REFERENCES}

Allport, Gordon W. \& Postman, Leo 1947. The Psychology of Rumour. New York: Henry Holt and Company.

Anderson, Walter 1926. Die Marspanik in Estland 1921. Zeitschrift des Vereins für Volkskunde. Begründet von Karl Weinhold. Berlin: Julius Springer, pp. 229-252. Available at http://www.archive.org/stream/zeitschriftfrv30t38verbuoft\#page/n5/ mode/2up/search/Die+Marspanik+in+Estland+1921, last accessed on July 11, 2017. 
Astapova, Anastasiya 2015. Negotiating Belarusianness: Political Folklore Betwixt and Between. Dissertationes Folkloristicae Universitatis Tartuensis 22. Tartu: University of Tartu Press. Available at http://dspace.ut.ee/handle/10062/49509, last accessed on July 11, 2017.

Barkun, Michael 2003. A Culture of Conspiracy: Apocalyptic Visions in Contemporary America. Berkeley \& Los Angeles \& London: University of California Press.

Blank, Trevor J. 2007. Examining the Transmission of Urban Legends: Making the Case for Folklore Fieldwork on the Internet. Folklore Forum, Vol. 37, Nos. 1-2, pp. 15-26. Available at https://scholarworks.iu.edu/dspace/handle/2022/3231, last accessed on July 11, 2017.

Blank, Trevor J. (ed.) 2009. Folklore and the Internet: Vernacular Expression in a Digital World. Utah: Utah State University.

Fine, Gary Alan 1997. Rumor. In: Thomas A. Green (ed.) Folklore: An Encyclopedia of Beliefs, Customs, Tales, Music, and Art. Santa Barbara \& Denver \& Oxford: ABC-CLIO, pp. 741-743.

Fine, Gary Alan \& Turner, Patricia A. 2001. Whispers on the Color Line: Rumor and Race in America. Berkeley \& Los Angeles: University of California Press.

Foucault, Michel 1980. Power/Knowledge: Selected Interviews and Other Writings 1972-1977. New York: Pantheon Books. Available at https://monoskop.org/ images/5/5d/Foucault_Michel_Power_Knowledge_Selected_Interviews_and_ Other_Writings_1972-1977.pdf, last accessed on July 11, 2017.

Foucault, Michel 1981. The Order of Discourse. In: Robert J. C. Young (ed.) Untying the Text: A Post-Structuralist Reader. London \& Boston: Routledge \& Kegan Paul, pp. $48-78$.

Frank, Russell 2011. Newslore: Contemporary Folklore on the Internet. Jackson: University Press of Mississippi.

Goldstein, Diane E. 2004. Once Upon a Virus: AIDS Legends and Vernacular Risk Perception. Logan, Utah: Utah State University Press.

Harris-Lopez, Trudier 2003. Genre. In: Burt Feintuch (ed.) Eight Words for the Study of Expressive Culture. Urbana \& Chicago \& Springfield: University of Illinois Press, pp. 99-120. Available at https://muse.jhu.edu/book/22934, last accessed on July 11, 2017.

Kalmre, Eda 2005. The Saga of the Voitka Brothers in the Estonian Press: The Rise and Fall of a Heroic Legend. Folklore: Electronic Journal of Folklore, Vol. 29, pp. 97-122. http://dx.doi.org/10.7592/FEJF2005.29.voitka.

Kalmre, Eda 2013a. The Human Sausage Factory: A Study of Post-War Rumour in Tartu. On The Boundary of Two Worlds: Identity, Freedom, and Moral Imagination in the Baltics, Vol. 34. Amsterdam \& New York: Rodopi.

Kalmre, Eda 2013b. Rumours and Contemporary Legends as Part of Identity Creation Process. In: Liisi Laineste \& Dorota Brzozowska \& Władysław Chłopicky (eds.) Estonia and Poland: Creativity and Tradition in Cultural Communication. Vol. 2: Perspectives on National and Regional Identity. Tartu: ELM Scholarly Press, pp. 25-42. DOI: 10.7592/EP.2.kalmre. 
Kapferer, Jean-Noel 1990. Rumors: Uses, Interpretations, and Images. New Brunswick, NJ: Transaction.

Madisson, Mari-Liis 2014. The Semiotic Logic of Signification of Conspiracy Theories. Semiotica: Journal of the International Association for Semiotic Studies, Vol. 202, pp. 273-300. https://doi.org/10.1515/sem-2014-0059.

Madisson, Mari-Liis 2016. The Semiotic Construction of Identities in Hypermedia Environments: The Analysis of Online Communication of the Estonian Extreme Right. Dissertationes Semioticae Universitatis Tartuensis 23. Tartu: University of Tartu Press. Available at https://dspace.ut.ee/bitstream/handle/10062/52174/ madisson_mari-liis.pdf?sequence=1\&isAllowed=y, last accessed on July 11, 2017.

Møllegaard, Kirsten 2005. The Fairy-Tale Paradigm: Contemporary Legend on Hans Christian Andersen's Parentage. Contemporary Legend: New Series, Vol. 8, pp. 28-46. Available at http://collections.mun.ca/PDFs/clegend/ ContemporaryLegendVol.082005.pdf, last accessed on July 11, 2017.

Neubauer, Hans-Joachim 1999. The Rumour: A Cultural History. London \& New York: Free Association Books.

Nycyk, Michael 2015. The Power Gossip and Rumour Have in Shaping Online Identity and Reputation: A Critical Discourse Analysis. The Qualitative Report, Vol. 20, No. 2, pp. 18-32. Available at http://www.nova.edu/ssss/QR/QR20/2/nycyk2.pdf, last accessed on July 11, 2017.

Regamey, Amandine 2011. Les femmes snipers de Tchétchénie: interprétaions d'une légende de guerre. Questions de Recherche / Research in Question, Vol. 35. Available at http://www.sciencespo.fr/ceri/sites/sciencespo.fr.ceri/files/qdr35.pdf, last accessed on July 11, 2017.

Renard, Jean-Bruno 2005. Negatory Rumors: From the Denial of Reality to Conspiracy Theory. In: G. A. Fine \& V. Campion-Vincent \& C. Heath (eds.) Rumor Mills: The Social Impact of Rumor and Legend. New Brunswick \& London: Aldine Transaction, pp. 223-240.

Shibutani, Tamotsu 1966. Improvised News: A Sociological Study of Rumor. Indianapolis $\&$ New York: Bobbs-Merill.

Shifman, Limor 2007. Humor in the Age of Digital Reproduction: Continuity and Change in Internet-Based Comic Texts. International Journal of Communication, Vol. 1, pp. 187-209. Available at http://ijoc.org/index.php/ijoc/article/viewFile/11/34, last accessed on July 11, 2017.

Tangherlini, Timothy R. 2007. Rhetoric, Truth and Performance: Politics and the Interpretation of Legend. Indian Folklife, Vol. 25, pp. 8-12. Available at http:// indianfolklore.org/journals/index.php/IFL/article/view/257, last accessed on July 11, 2017.

Turner, Patricia A. 1993. I Heard It Through the Grapevine: Rumor in African-American Culture. Berkeley \& Los Angeles \& London: University of California Press.

Valk, Ülo 2008. Folk and the Others: Constructing Social Reality in Estonian Legends. In: Terry Gunnell (ed.) Legends and Landscape: Plenary Papers from the 5th Celtic-Nordic-Baltic Folklore Symposium, Reykjavik 2005. Reykjavik: University of Iceland Press. 
van Dijk, Teun A. 2001. Critical Discourse Analysis. In: D. Tannen \& D. Schiffrin \& H. E. Hamilton (eds.) Handbook of Discourse Analysis. Malden, MA \& Oxford, UK: Blackwell, pp. 352-371. Available at https://lg411.files.wordpress.com/2013/08/ discourse-analysis-full.pdf, last accessed on July 11, 2017. 


\title{
RUMOR, HUMOR, AND OTHER FORMS OF ELECTION FOLKLORE IN NON-DEMOCRATIC SOCIETIES: THE CASE OF BELARUS
}

\author{
Anastasiya Astapova \\ Department of Estonian and Comparative Folklore \\ University of Tartu, Estonia \\ e-mail: anastasiya.ast@gmail.com
}

\begin{abstract}
This article focuses on folk expressions on "the election without choice", as the state elections in authoritarian societies are often labeled. The research is based on the case of Belarus, where the electoral fraud has become a matter of common knowledge both for the Belarusians themselves and outside observers. Yet, even though the independent opinion polls are not exactly as positive for the Belarusian president as the official results of the election, they show that Alexander Lukashenko wins within the self-sufficient system he has created. This hegemony is nurtured, for instance, by various manifestations of the election sham reproduced by Belarusians. At the same time, the election rumors and jokes circulating in the oral communication and on the Internet question the existing hegemony. By means of fieldwork examples I show in this article how the genres of rumors and jokes are interconnected, sometimes to the point of being indiscernible. Rather than looking at the borders of the two genres, I will concentrate on their interplay, intertextual bridges between them, the ideologies they share, and new directions for understanding the non-verifiable folklore they provide.
\end{abstract}

Keywords: Belarus, election folklore, election fraud, genres, humor, intertextuality, jokes, rumors

On Sunday, October 11, 2015, I decided to discharge my civic duty of a Belarusian citizen by voting in the presidential election. As I live outside of Belarus with an Estonian residence permit, I went to the Belarusian embassy in Tallinn to vote. The personnel were very welcoming, and the procedure did not take long. The employees of the embassy asked me for a passport, filled out my data in their papers, and issued a ballot to me. I made my choice in the voting booth, put the ballot into the ballot box, thanked the personnel, and left - following the election procedure typical all over the world.

Once I had left the embassy, however, questions about how typical the procedure was started to rise in my head. The personnel of the embassy did not 
ask for my Estonian residence permit - how could they be sure that I lived in Estonia? They did not check it in any lists or databases; they only had tables on paper where they recorded my name. How did they know that I did not vote in the same way in the Belarusian Embassy in Latvia, Lithuania, Russia, and even in Belarus itself - taking into account the fact that the preliminary voting for those who cannot vote on the Election Day began five days before, on October 6? Had they later discovered my multiple votes by comparing their lists with other embassies, how would they have found which ballots were mine to make sure that their multiplicity would not have influenced the election results? Can the voters just purposefully "haul" from one poll to the next? These multiple questions were followed by the feeling of disappointment over how useless my voting might have been.

Posing these questions already required vernacular terminology to refer to potential fraud in such a situation. Multiple votes at several polling stations, until recently possible in the United States, were called "floating" or "boodle" (Sarvis 1998: 52). In Belarus, the practice of voting multiple times acquired the name of "merry-go-round" (karusel'), with people paid to take part in it called "merry-go-rounders" (karusel'chiki) (United Civil Party 2015). As I will show further, there is a broad vocabulary for the description of potentially fraudulent elections in its different aspects.

In addition to this vernacular terminology, I started to think about multiple rumors I had heard before the Belarusian presidential election, all accusing it of fraud. Since its 1994 declaration of independence from the Soviet Union, Belarus has had five elections, and at least the three of them that I remember were accompanied by rumors, bitter jokes about the situation, and many other forms and genres of folklore. For instance, at the 2015 elections, the opposition claimed that all the voices would be faked, and called for the boycott of the elections. Undoubtedly, this specific vernacular reaction appears due to the fact that at each and every election one and the same person - Alexander Lukashenko - has won, allowing many to consider Belarus an authoritarian society. Rich folklore, however, accompanies all elections, not only those conducted in dictatorships.

\section{ELECTION FOLKLORE}

Elections have been studied extensively in political science, both synchronically and diachronically. Folklorists, however, have not paid much attention to elections, apart from the random recognition of expressive culture associated with Election Days (Sarvis 1998: 42). The majority of existing works on elections 
are based on US materials. One may suppose that rich Election Day traditions emerged due to the strong narrative of American democracy. Indeed, works on American nationalism show how special the character of political engagement is in American elections (Dinkin 2002; Gamber \& Grossberg \& Hartog 2003; Patterson 2003; Schudson 1998). Due to this, American folklorists often analyze Election Day celebrations per se (Fabre 1993; Santino 1994; White 1993) or separate issues which become particularly important at certain elections (Granberg \& Burlison 1983). Meanwhile, as far as I know, only one piece of research concentrates on the rumors of election fraud (Sarvis 1998). Its author, writing about such rumors in postwar rural Missouri, claims that "election fraud is an appropriate subject for oral history and folklore in common with many other topics that involve truth, even though they will not pass the rigors of logics and 'proof' required in courts of law or in history articles" (Sarvis 1998: 69). In the United States, he argues, the great deal of reasonable doubt, the time factor, and the potential expenses keep election fraud testimonies outside of the judicial system, and thus beyond rigorous examination for truth, belief, and invention. "But truth, belief, and invention exist in the oral tradition, and the folklore legacy of election fraud in itself contributes profoundly to suspicion and distrust, even paranoia, around election time in certain locales" (Sarvis 1998: 69). Of course, the situation in Belarus is very different both from postwar Missouri and today's American elections. For instance, different reasons, such as fear and Soviet election tradition, keep Belarusians from examining election fraud rumors in court. Nevertheless, I will draw on the material provided by American researchers, who were among the first to recognize the potential of election folklore analysis.

There are some studies on elections that also go beyond the American focus. For instance, there is a 1994 collection of urban legends related to South-African elections. One of the most prominent stories in it is "Ink in the porridge". According to it, one of the opposition leaders claimed that the National Party offered porridge laced with ink to black voters. The intent was that the ink would show up under the ultraviolet lamps on the Election Day, and the black voters who consumed it would be disqualified from voting for the African National Congress - the main opposition to the National Party (Goldstuck 1994; Kaschula 2004: 867). Such conspiracy theories often become relevant at the elections. One of the most well-known examples is that following the election of the first US African-American president, a wave of conspiracy theorists rose to prominence through claims that Barack Obama was not a natural-born citizen (Gencarella 2010: 260). They argued that he had not been born in Hawaii, but rather in Kenya (there are other versions as well); thus, he is not a natural-born citizen of the United States and is ineligible to be a president of the country. These 
rumors became a tool for othering Obama and expressing discontent with him through the assumption of his illegitimacy as a president. Both African and American examples concern race, although this is not always the case in the election folklore in other societies.

Quite a bit has been written on the Iranian elections: folk expressions, postelection protests, and the Internet, among other driving forces (Honari 2014; Kamalipour 2010; Rahimi 2013, etc.). Several scholars concentrate on the voting cultures emerging after the Arab Spring (Davis 2013; Muravchik 2013; Weddady \& Ahmari 2012, etc.). Isolated studies exist on election humor and protest in post-Soviet bloc countries like Russia (Alekseevsky 2010; Arkhipova 2012; Arkhipova \& Alekseevsky 2014; Erpyleva \& Magun 2014) and Hungary (Varga 2015). The Soviet elections have become a matter of thorough analysis by many scholars, almost none of them folklorists. Among unconventional objects for analysis, archival research also allows for access to messages that non-conforming voters put in the ballot boxes or wrote on the ballots during Soviet elections (Kozlov \& Mironenko 2005; Merl 2011). These messages often openly address and criticize political leaders or carry complaints about how poor the citizens' lives are.

The list above is not, of course, exhaustive, but is meant to highlight the main research directions in the rather undeveloped field of election folklore analysis. Many other phenomena of electoral creativity in Western democracies remain unaddressed in the research: for example, non-human electoral candidates, practical jokes during elections (when the voters are informed that the election has been cancelled (Watts 2006: 125)), political parties and candidates created exclusively for frivolous purposes (parody, joke, hoax, etc., often successfully elected), various post-election protest tactics, the candidates' amulets and lucky omens, customs accompanying the closure of the polls, etc. (Pound 1959: 189).

One of the common questions asked by election research is how the voting behavior and narratives about elections reflect the voters' civil values. As Molly Anders notes, political narratives are not necessarily overtly about politics, but "these stories often reveal how individuals position themselves within the communities that they live" (Andrews 2012). Folklorist Paulina Latvala adds that narratives consist of emotions about everyday political atmosphere and many genres of political folklore represent the conflicting values - past and present - in the community (Latvala 2014: 121). It is undoubtedly within the domain of folklore studies to follow, ask about, and analyze individual positions and values of voters, expressed through different genres in various contexts. The context of the Belarusian elections may present particular interest for the folklorists, and below I am going to specify what is so distinct about it. 


\section{THE BELARUSIAN CASE}

The Belarusian case reminds us of the aforementioned idea of William Sarvis, who argued that folklore legacy of the election fraud in itself contributes profoundly to suspicion and distrust (Sarvis 1998: 69). Belarus became independent from the Soviet Union in 1991, and it is needless to say that its 70-year history within the Soviet Empire did not create a sense of honest elections (Jessen $\&$ Richter 2011). It should be mentioned from the beginning that Belarus has been undoubtedly the most Russified country within the Soviet Union, due to the similarity of the Belarusian language to Russian and the previous history of Russification within the Russian Empire. This Russification also resulted in a dedicated following of the direction sent from the Moscow center and a shock after the Soviet Union's collapse. In March 1991, 83\% of the Belarusian voters were in favor of retaining the integrity of the USSR - a higher percentage than in any other Soviet republic outside Central Asia (Blacker \& Rice 2001: 226; Rudling 2015: 2).

Still, after the Soviet Union's collapse, nationalist discourse emerged in Belarus, as it did in all the post-Soviet republics. It did not only promote the nationalist version of history, claiming that the Soviet Union had aimed to destroy the Belarusian consciousness and people, but also stimulated the replacement of the Russian language with Belarusian. The latter did not go so well, as in the post-Soviet 1990s most Belarusians could not speak their own language, and the language itself was not ready to be fully implemented: for instance, it lacked scientific and political terminology (Rudling 2015: 211). In addition, the new national symbols proposed were associated with World War II collaborationists who were condemned throughout the Soviet period. All these nationalist changes were imposed too hastily by the Belarusian Popular Front Party and its leader, Zianon Pazniak. Belarusians did not identify with the newly offered consciousness, and the surgical operation of the immediate separation of the Belarusian and Soviet ideology could not be successful (Bekus 2010: 80).

Small wonder that when Alexander Lukashenko, opposing radical nationalism and promising to preserve many Soviet Empire values in his "retro-project" (Bugrova 1998: 32), showed up on the political arena, he immediately won the hearts and votes of the Belarusians. He became a certain relief for the majority of Belarusians, doubting the hastily implemented and strange nationalist discourse. Challenging the nationalist inclination of the new Belarus, proposed by Zianon Pazniak, Lukashenko promised familiar stability. This was a much more important matter for the people who had experienced the uncertainty and economic difficulties of transitional post-Soviet years than the imagined return 
to Europe. Lukashenko beat Zianon Pazniak at the first, 1994 presidential election, gaining $44.82 \%$ of votes in the first round and $80.1 \%$ in the second one.

After this victory, Lukashenko gained more and more popularity by preserving what he had promised; this allowed him to hold a referendum in 1996 to change the constitution and to start his 5-year term count anew. The referendum was unacknowledged by Europe and the United States (BBC news 2006) and considered fraudulent by the opponents of Lukashenko. In 1999, opposition members declared Lukashenko's presidential term over, protested openly, and tried to hold an alternative election. Their major candidate was soon imprisoned and the protests were violently suppressed.

The 2001 election, at which Lukashenko won again, was characterized by the Organization for Security and Co-operation in Europe (OSCE) as undemocratic and unfair (BBC news 2001). Yet, according to the constitution, it seemed that this was Lukashenko's last term. To secure his place, however, he held a new referendum in 2004, offering the following question:

Do you permit the first President of the Republic of Belarus, Lukashenko A.G., to participate as a candidate for Presidency of the Republic of Belarus during the presidential elections, and do you accept Part I of Article 81 of the Constitution of the Republic of Belarus in the following wording:

"President is elected for the term of 5 years directly by the people of the Republic of Belarus by means of the universal, free, equal, and direct suffrage by voting by secret ballot"? (The Central Commission 2004)

According to the results of the 2004 referendum, the majority of voters allowed Lukashenko to change the constitution and to participate in an unlimited number of new elections. Despite multiple objections of the opposition, he used this possibility in 2006, winning his third election. The third election in 2006 and the fourth one in 2010 were accompanied by plenty of protests, which were violently suppressed by the government. The latest, fifth election (2015) included four candidates, a female candidate from the opposition among them. According to the official statement, the results were as follows: Alexander Lukashenko 83.47\%, Tatiana Karatkevich 4.44\%, Sergei Gaidukevich 3.30\%, Nikolai Ulakhovich $1.67 \%$, against all $-6.32 \%$ (Naviny.by 2015a). This election gathered only a few protesters in the streets of the capital.

Every election since at least 2001, including the last one, has been accompanied with accusations of fraud by the opposition and the disapproval of the international observers. It is hard to say whether fraud - the main topic of the Belarusian election folklore - has taken place, and if it has, then to what extent. Still, there is no doubt that there are many fundamental flaws in the electoral process, of which many are specific to the political situation in Bela- 
rus and recognized by the political science researchers. Undoubtedly, the current Belarusian state is not accustomed to opposition and does everything in its power to block it. The campaign environment seriously disadvantages the opposition candidates; oppositional activists are intimidated. State-controlled media is highly biased in favor of Lukashenko and the independent print media is censored. Extensive power of executive structures allows for the electoral environment to be arbitrarily changed; weak legislative framework fails to ensure independent legislative bodies and imposes excessive restrictions on campaigning and observers (Korosteleva \& Lawson \& Marsh 2003: 193-194). To conclude, the elections in Belarus are held "freely, but under unfair circumstances" (ibid.: 194). The authoritarian leadership wins at what is represented as democratic elections. Even if the opinion polls are not exactly as positive as the results of the election, one has to recognize that Lukashenko wins within the system he himself has created.

To imagine the situation better, one must keep in mind that Lukashenko gained power over a country which was still very Soviet, promised to preserve many Soviet values, and has been quite successful in it. Modern Belarus is often compared to the Brezhnev Era of Stagnation (Savchenko 2009: 188), the state of being stagnant, or not moving, not as horrifying as the Stalinist time, but still far from being a democracy. Further on I will show how the Belarusian voters reproduce the system, making it more and more self-sufficient. At the same time there is no contradiction between reproducing and defying the system, both of which coexist in Belarus.

As James Scott claims, subordinates react to what is imposed on them by power holders in different folk expressive ways, including rumor, gossip, jokes, and rituals, among others (Scott 1990: 19). What is more, if the domination is particularly severe, it is likely to produce folk expression of corresponding richness (ibid.: 27). Indeed, Belarusian election folklore has become so widespread and creative that its genres intermingle to the extent that it is impossible to tell one from another; they move from one election to the next whether through oral communication, news, or the Internet.

\section{METHODOLOGY OF FIELDWORK AND ANALYSIS}

The material collected for this article was drawn from two sources. First, in 2011-2015, I carried out over fifty informal, open-ended interviews about the issues of political and ethnic identity with Belarusians living in Belarus and those who had emigrated from the country. Most of the interviews were held in Vitebsk and Minsk; some were held among the Belarusian diaspora in foreign 
countries - Russia, the United Kingdom, the United States, Poland, Estonia, Lithuania, and China. I mostly interviewed those who volunteered for it. For instance, Belarusian friends posted information on social networking sites, announcing that there would be a native scholar coming to Belarus, researching political and ethnic identity. Correspondingly, those people who were interested in voicing their opinion on these issues contacted me. Also, whenever I went to a foreign country, I looked for Belarusians there through acquaintances in Belarus (and Belarusian diasporas) or through simply searching for Belarusians on the Internet in the countries I was visiting (these were mainly very active people I could find through googling, for instance, 'Belarusians in China'). Through these methods, I found and interviewed most of the respondents; these were mainly men aged between twenty-five to forty-five years, who volunteered to be interviewed on the subject of politics. It seems to me that they were representative of the politically aware and interested part of the Belarusian society and diasporas. Compared to many others, who were reluctant to speak about politics, they form a rather distinctive sample characterized by sensitivity towards, concern about, and awareness of political issues, as well as by openness to discuss them. At the same time, the interviewees were of different political mindsets, not necessarily oppositional to the current government. I have mentioned that the majority of the informants were males, and the position of many women regarding politics in Belarus, meanwhile, is well-characterized by the following excerpt from an interview:

- Do you think that the elections may have been falsified?

- Yes, there were many proofs, I think. Formerly I was younger and more passionate, but my parents laughed at me, understanding that we cannot change anything. Formerly I could not understand them; I asked, "Mom, why don't you go to protest?", but now I also think like they do, and I understand that many positive things are done in our country too. Culture is being developed now, journalists write about culture, handmade art develops. I am a girl and I do not interfere in politics.

(Recorded from a 21-year-old female in Minsk, 2012 (emphasis mine))

This interview is representative of a widespread position of women regarding the Belarusian political situation. They often claim that people themselves cannot change anything in the country, are satisfied with positive developments, and self-identify as women who are not supposed to deal with politics or even have a strong opinion on it. Undoubtedly, I cannot judge for the whole Belarusian female population, as I have not done any statistical research, but several interviews (as quoted above) and the general reluctance of Belarusian women to participate in the research on politics were quite demonstrative. At 
the same time, I had at least three interviews with females expressing their political position with confidence.

Due to anonymity promised to the participants, the interviews have only very basic references: I mention where and when the interview was recorded as well as the age and gender of the interviewees. Before the interviews, I prepared a basic plan of the main topics and questions to ask, including the general election and the possibility of frauds in its results. I did not always follow the interview plan, but let the interviewee speak more on the issues he or she was interested in. This means that some interviews contain large pieces on the election, while others carry almost no opinion on it at all. Many interviews also contain election jokes, which are among the most popular political jokes in Belarus, told not only around the time of the election.

Having conducted all these interviews, unfortunately, I did not have a chance to be in the country during the latest, 2015 election. That is why I decided to complement the interview data with distance fieldwork on the Internet. In addition to real-life fieldwork, this is the second source of my research. Firstly, the article is largely based on the election folklore my Belarusian friends shared via social networks. This is the approximate collection of rumors, jokes, and other genres accessible to the average Belarusian Internet-user, who can be both an active promoter and a passive receiver. They mainly appear in the internet statuses and reposts of certain groups from Facebook and its Russian-language analogue Vkontakte (www.vk.com). To guarantee anonymity to the informants who did not even know that they were my informants, I have omitted all their data; hopefully, by translating the material from Russian or Belarusian into English, I have made its search on the Internet more difficult. Secondly, I browsed the news and comments upon the 2015 election results on the main Belarusian online mass media. Thirdly, I went through the hashtags on Facebook and Twitter, all related to the Belarusian 2015 election: \#vybar_by ('election_by', the most widespread one),\#выборы_без_выбора ('election_without_choice'), \#выборытут ('election here'), \#БеларусьВыбирает ('Belarus elects'), \#Выборы2015 ('Elections 2015'), \#naziranne ('observation' in Belarusian), \#BSDP (the abbreviation for the oppositional Belarusian Social Democratic Party Hramada). Finally, I examined a comparatively new group that emerged in the Russian-language social network website Vkontakte. The group Grustnyi Kolen'ka ('Sad Kolen'ka') appeared before the 2015 presidential election (Vk.com 2015); it posts as if on behalf of the youngest son of Lukashenko, Kolya (born in 2004). The name of Kolya's mother is still unknown, but Kolya is obviously the apple of his father's eye, being brought to all sorts of official events and places, from churches to military parades. In addition to popular indignation over this, the figure of little Kolya is surrounded with rumors - not only who his mother really is and 
how terribly capricious, if not psychologically unstable, he himself is. According to recurrent half-joking folk statements, Lukashenko prepares Kolya for the presidency. Due to the fact that in an authoritarian society Lukashenko is the only widely known official actor of Belarusian politics (an average Belarusian will hardly even remember the name of the prime minister), another known figure, Kolya, also becomes a protagonist both of rumors and jokes.

The posts in one Vkontakte group (with more than 2300 members at the time of writing this article), jokingly attributed to Kolya, comment on Belarusian current events and his life with his father. It opened a few months before the 2015 election.

Just imagine, daddy snores the hymn of Belarus. (November 3)

Daddy is lucky. I always have to learn different poems at school, while he learns the same inauguration text every time. (November 1)

Today BATE [the Belarusian football club] plays with Barcelona. The intrigue is comparable to that at the Belarusian election. (October 20)

Many of Kolen'ka's posts are also about the elections, and I will further use them in the article. The Internet in general becomes a significant scene and a meeting ground for questioning the existing system - as the real protests are suppressed and the access to offline public space is limited and regulated.

Undoubtedly, a major source of the election folklore is the accounts people give on how they voted, although the Internet is now becoming an important environment giving way to new forms of communication. Among the most unusual and rare forms on the Internet, I should single out the game available on Google Play, dedicated to the Belarusian elections, with the following description:

Do you know there are "president elections" in Belarus this year? Unfortunately wind of change has blown all the candidates away. And they're leaving using air balloons. But no candidates - no elections... You're playing as Master Lida - well known belarusian [sic] elections wizard. And you must stop all the candidates from leaving the elections. So take your gun and start your job:) And remember: elections results depends [sic] on you now! Only on you :) (Google play 2015)

The irony of the description is first of all in calling Lydia Ermoshina, the chairwoman of the Central Election Commission of Belarus, often accused of arranging the election fraud, an election wizard. Secondly, the final sentences of the text mock the agency of Belarusians: the election results depend on them in the computer game only. It is a common phrase in Belarus that "everything 
has been decided for us", meaning that Lukashenko will be elected anyway, no matter how one votes.

Another comparatively old genre, which has now gone viral due to the Internet, is when people request their co-citizens to participate in the election and vote for Lukashenko. As many of my interviewees reported, people working in state organizations - schools, hospitals, universities - are usually forced to make those calls on the Internet. These videos are not funded in any way; people have to make them on their own, and they are usually very unprofessional. A typical video takes place in the street where a young speaker with the Belarusian flag is supposed to utter a text similar to the following: "I am going to the election because I have an active civil position, and I will vote for a strong and independent Republic of Belarus!" (Youtube 2015). It is mainly younger people who are involved in the voting campaign, for Lukashenko in particular. Similar to the Soviet Union (Tsipursky 2011), the election becomes a venue for the expression of youth agency, allowing the government to appear as if it conveyed the desires of the next generation, also teaching them how to behave according to the political requirements of the state. Finally, low level of professionalism in making videos is perhaps supposed to be a sign of authenticity - people themselves striving to agitate for Lukashenko with the sources at hand.

In response, however, the opponents of Lukashenko, also quite young, make videos calling for a different action. In a short film made by a Belarusian student, a young man comes to visit his grandmother, when two activists ring her doorbell to collect signatures for Lukashenko. After they have made the grandmother believe how good Lukashenko is, they ask her to bring her passport to sign for his candidacy. Her grandson immediately rushes to her bedroom and hides the passport. The video ends with the text: "19 December [the day of the Belarusian election 2010]. Hide grandmother's passport” (Ru.tsn.ua 2010). Elderly females are Lukashenko's main supporters, and the video suggests eliminating their votes. The video was created to go viral, attract Internet users, and make them further disseminate the link through reposting and sending it to friends. It has been reported, however, that the student who had made this video was fired from his state job (ibid.).

In addition to these rather random examples, the major part of the article below will be dedicated to the most recurrent themes and genres of the Belarusian election folklore. I have divided the article into several subchapters for the sake of structure, but, as the reader will see further, the borders between motives, genres, and issues are fuzzy as there are no clear-cut categories in the material. Constant tension between Lukashenko's followers and their opponents undoubtedly increases during the election, reinforcing a variety of existing intermingling political folklore motives. 


\section{FOODWAYS AND OTHER EXPRESSIONS OF POTEMKINISM AND HEGEMONY}

One of the major images of the Belarusian presidential election in 2015 was that of the food in the polling station in which Lukashenko himself voted. Figure 1, as also many other pictures on the Internet, demonstrates the abundance of dishes available in the buffet there, also at unbelievably low prices.

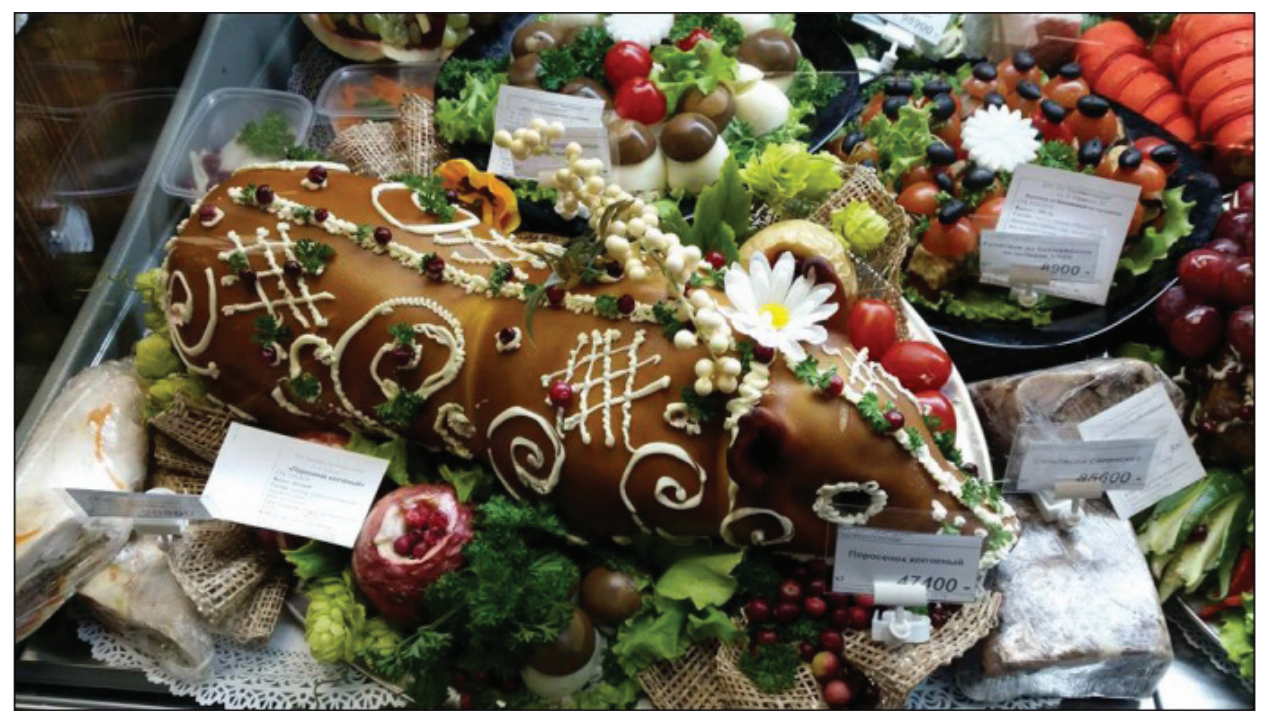

Figure 1. The buffet laid out at the polling station where Lukashenko voted (Grodno 2015). Source: http: / /grodno24.com/belarus / bufet-na-prezidentskom-uchastke-raduetizbiratelej-smeshnyimi-czenami.html.

This and other images of prosperity and plenty were paradoxically created by the citizens for the president of Belarus at the polling station where he voted. This goes in line with the general tendency of erecting false, "Potemkin" façades for the president as well as high officials in Belarus. The essence of the Belarusian Potemkinism is well conveyed by a joke in the Kolen'ka group: "Hearing the sound of daddy's helicopter, even broken combine harvesters start reaping" (Vk. com 2015). In Belarus, the common socialist phenomenon of Potemkinism was planted into the fertile ground of Soviet templates and the paternalist state with its set of reliable rules. In the Soviet period, the polling stations often provided goods otherwise not available, to attract people to participate in the elections. 
I have recorded multiple interviews about Potemkinism in Belarus, where people report about grooming special conditions when Lukashenko or other officials come to different enterprises and cities (Astapova 2015). The leader seems to provide peace, prosperity, and stability, and Belarusians, in return, play according to imposed rules. They reproduce the hegemony by participating in the offered system, which seems to be paid off by socialist guarantees and other benefits.

Many fragments of the interviews about the elections I recorded were also associated with pleasing the president: for instance, many interviewees employed by state-funded organizations reported on having had to collect signatures for Lukashenko before the election. They often had fewer signatures than expected, which was a matter of concern and caused fear of problems at work as a consequence. The modality of collecting signatures for the president is similar to making fancy foods at the polling station where Lukashenko voted, and to shooting videos agitating for the president or for the election. On the one hand, people are forced to do so by minor officials; on the other, they do not openly resist, thus supporting the existing hegemony.

Another similar act of the same modality is amateur performances organized at the polling stations to entertain the voters. In addition, farmers' markets, free souvenirs (pens, notepads, etc.), and cheap alcohol available at the polling stations (Minsknews 2015) are supposed to attract more voters to have a successful election. This has been a widespread Soviet practice too, when "thousands of shows, dance performances and concerts were put on in order to entertain the voters" (Jessen \& Richter 2011: 9), staging an "election without choice" - a common reference to the elections in the authoritarian regimes (Hermet \& Rose \& Rouquie 1978). Another common definition of the elections in non-democratic societies is "rituals of consensus" (Jessen \& Richter 2011: 14), underlining the affirmation of government legitimacy (Jessen \& Richter 2011: 20; Tsipursky 2011: 88) and mass obedience (Richter 2011: 103). The activities - from coming for a buffet to performing at the election stations - become the indicators of conformism, showing the citizens' preparedness to take part in the ritual demonstration of loyalty (Jessen \& Richter 2011: 23). Such elections buttress the regime by showing that the illegitimacies of its practices have been accepted and that no action to undermine it is forthcoming (Zaslavsky \& Brym 1978: 371). Choreographing such elections includes impression management to show that the regime is based on mass support (Patzelt 2011: 141) - in other words, erecting a democratic façade in front of the dictatorial regime.

This has been the legacy of many other post-Soviet countries, Central Asian ones among others, where elections legitimate power rather than provide an opportunity to challenge it (Ó Beacháin 2011: 209). They also perform politi- 
cal agency of the people rather than really cede it. A sham election, also called a 'rubber stamp election' or a 'show election', is held without any significant political choice. Interestingly, it does not have a stable name in Russian or Belarusian, and the terms pokazatel'nye vybory or pokazushnye vybory ('show elections'), which might suit, are rarely used. An alternative notion of vybory bez vybora ('elections without choice' - as vybor is an homonym for both choice and the elections) seems to be more widespread; it even led to the creation of a hashtag for the Belarusian election \#выборы_без_выбора. The lack of choice and the impossibility of change is one of the constant topics of discussions and conclusions about the presidential election results, also reflected in humor:

There is a high probability of a victory of a dude with a moustache. (Twitter 2015)

Kolen'ka: Daddy asked me to write 'Lukashenko' in cubes of ice. I say: "Perhaps, 'eternity'?” He: "Did I say something else?” (Vk.com 2015, August 20)

[This is a reference to Hans Christian Andersen's fairy-tale “The Snow Queen", in which the Snow Queen gives a task to the little boy she kidnapped, Kai, to form the word 'eternity' from cubes of ice.]

The election in Belarus resembles a game, in which the participants must run around a chair [musical chair game], but in Belarus somebody already sits on this chair. (Vk.com 2015, September 17)

On October 11, 2015, there is an election of my daddy. Oh, I mean, the president. Although... That is right... Of my daddy. (Vk.com 2015, July 3)

Belarus holds a referendum: "Do you want Lukashenko to become President again?" The answer choices are: "Yes, I am not against this"; "No, I am not against this”. (Recorded from a 35-year-old male in Tallinn, 2012)

The head of the Central Election Commission turns to A.G. [the abbreviation for Alexander Grigorievich - the first and patronymic names of Lukashenko]: "I have two pieces of news for you: a good one and a bad one." - "Start with the bad one." - "Nobody voted for you." - "And the good one?" - "You are the president anyway". (Recorded from a 24-year-old female in Vitebsk, 2011) 
The results of the beauty contest "Miss Belorussia 2002" amazed everyone; the jury was conferring for a long time, productively though. The winner was Lukashenko. (Recorded from a 28-year-old female in London, 2011)

The sham of the Belarusian election is even more visible in the function of the election foodways. In contrast to Belarusian food abundance described by the press, Joyce M. White describes the tradition of the Election Day Cake baked in the United States by American citizens on the Election Day. The cakes are baked at home and shared with the family and friends. According to White, baking the cake is associated with the pride of successfully completing a difficult culinary task and glory in symbolically representing American ideals of democracy and freedom (White 1993). Undoubtedly, both Belarusian and American Election Day foodways legitimize the systems in which they emerge through the citizens' involvement in them. The systems are, however, based on different values - the choice in one case and the picture of plenty in the other. However, the Belarusian sham, a part of the suppressive system, is often a voluntary act. As I will show further, people participate in the election show out of their own free will, and some even initiate their own endeavors.

Accounts of Potemkinist or sham elections - whether in individual reports on voting or in the oppositional press - often involve joking. According to the words of one Twitter user, "The question of the day is: are chips expensive in the canteen?" (Twitter 2015). The canteen is obviously at a school, where the polling stations are often housed, and, according to the joke, there is no intrigue in the elections per se: even trivial food, such as chips, is of more interest. The interest in food rather than election results is also described in the following Twitter joke:

A dialogue in a buffet:

"Why is it so cheap?"

"In honor of the elections!"

"Oh, I am going to vote for Karatkevich then [the second most popular candidate after Lukashenko]. I want a second tour and the same prices again." (Twitter 2015)

The low prices of alcohol at the election buffets became another matter of multiple Twitter jokes: "At one of the polling stations everyone who voted gets 1.5 liters of beer! And everyone who voted correctly also gets a dried fish" [typical snack to go with beer in Belarus] (Twitter 2015). Trading alcohol for votes has been a common practice in many countries (Sarvis 1998: 52; Watts 2006: 
125). The Belarusian case is certainly not a pure case of trading, but a way to attract more voters to support the legitimacy of the elections (as it was in the Soviet era). The incompatibility of two constituents - the location of polling stations in schools and alcohol - also becomes a target of humor:

One of the voters decides not to stint, buys a bottle of vodka, hides it under his jacket, and asks whether he can buy cigarettes too. "Of course not," the saleswoman answers, expressing her indignation. "We are at school after all!" (Pikabu 2015)

The incompatibility of different frames is exactly what produces humor in general. According to one of the leading theories of humor, laughter emerges at the point of bisociation - the combination of two ideas from different contexts, which did not seem compatible before (Koestler 1964). When these two contexts or scripts, which were extraneous to each other before, become associated, cognitive dissonance emerges, compensated with the reaction of laughter (Attardo \& Raskin 1991). In contrast to jokes in general, where two concrete scripts come together to produce jokes, in Belarusian jokes it is the incompatibility of window-dressing and reality that produces cognitive dissonance.

The state-orchestrated exhibitions are not openly defied by their citizens: conversely, Belarusians reproduce them by shaping their behavior around these representations. Judging from the interviews, however, such representations are realized to be false, incomparable with everyday real life, when everything is much more expensive and less fancy. The humor becomes self-mocking, as it exposes the tellers' own contradictory and self-duplicitous behavior (Oring 2004: 224). As in the Soviet period, the jokes expose "the coexistence of two incongruous spheres, official and parallel, and the subject's simultaneous participation in both" (Yurchak 1997: 180). I am reluctant to claim that these jokes are indications of either resistance or disregard of the election. Rather, they are logical responses marking the natural need to react to the overwhelming sensation of the election sham and the Belarusian political system in general, the product of reflection upon what is going on, and one's own attitudes towards these circumstances. Such jokes do not just express opinions, but crystallize them in aesthetic forms (Oring 2004: 227).

Political humor in Belarus, like in other countries, is closely interrelated with rumors. To understand all the nuances of previous jokes, one, for instance, has to know of a rumor, according to which the main aim of Lukashenko is to draw the voters to the polling stations - it is only after they have voted that the results may be falsified. Drawing people - who realize that the votes they bring will be falsified - to the polling stations with food becomes one more incongruity. Many other examples also show how interrelated jokes and rumors are with the mass media. 


\section{BELARUSIAN VALUES VS. EUROPEAN DEMANDS: LUKASHENKO UNDERSTATING THE ELECTION RESULTS}

It is not only personal accounts that transmit the oral history of the election. As early as 1994, Linda Dégh thoroughly analyzed the application of mass media to create or shape new folklore (Dégh 1994: 4). The press sometimes becomes inseparable from folklore expressions, and the news turn into a folk genre. A perfect example of this is the following declaration Alexander Lukashenko made at a press conference after the 2006 election:

Yes, we falsified the latest election - I have already said it to the Westerners. 93.5\% of people voted for President Lukashenko. It is said that this is not a European figure. We turned it into 83\%. This is the truth... This is because the Europeans told us before the election: "If you have approximate European figures in the election, we will recognize your election." We tried to make them European. But also, you see, it did not work. They promised that all will be fine if the figures are European. We made them Europeanand this is not fine. (Youtube 2006)

In this statement the president, perhaps, unintentionally (Lukashenko has been notorious for his slips of the tongue) confirmed the rumors about frauds circulating around the elections. The confession was shocking, although the manipulation of the election, according to Lukashenko, was to understate the high percentage of people who vote for him. Interestingly, this confession, reflected in the news, became associated with humor: when I asked the interviewees to tell Belarusian jokes to me, one of the informants retold Lukashenko's statement, among other classical political jokes:

I remember one more slip of the tongue. After the election, I think after the previous election... He said that he got the highest percentage, but nobody believed him. And the percentage of those who voted for Lukashenko was not to the taste of some observers, perhaps, from the European Union. Then he said: they did not like such a high percentage, and we changed it to, let's say, $75 \%$, and they are still not satisfied.

(Recorded from a 35-year-old male in Tallinn, 2012)

A piece of news supporting the rumors turned into a piece of humor. The comparison of these two texts evokes many other examples when a slip of the tongue becomes meaningful, and the border between the news, rumors, and jokes fluctuates. This is further complicated by the dubious nature of Belarusian official statements and lack of sources for reliable information. 
Whether characterized as a rumor, a piece of news, or a joke, Lukashenko's confession of election fraud evokes more conclusions of a different sort. It becomes an example of what is often ascribed to non-democratic elections: dictatorships have to work at creating a façade of democracy (Patzelt 2011: 135), similarly to other cases of Potemkinism discussed above. Here, Potemkinism takes place through Lukashenko's paradoxical understating of the number of votes he received. Small wonder that Lukashenko's statement becomes confirmed by a new wave of rumors: "You know, I heard the following fact from the election commission: they were forced to decrease the votes - to hold back, as there were too many for Lukashenko" (recorded from a 30-year-old male in Minsk, 2013).

Patzelt, quoted above, adds that "in dictatorship election results can of course be manipulated in many different ways. If manipulation becomes known or even highly visible, this leads to a loss of trust and support in the regime among the followers" (Patzelt 2011: 127). The official confirmation that the elections had been falsified, even if to understate the percentage of votes for the authorities, undoubtedly posed many more questions, leading to the understanding that fraud in the other directions is also possible, if it is so openly recognized by the leading power. This certainly leads to the appearance of many more rumors, mostly ones about the overstatement of votes for Lukashenko.

\section{PRO-LUKASHENKO ELECTORAL FRAUD}

According to the narratives I recorded, the election in Belarus was falsified in a number of ways: changing the ballots at night, faking the election protocol, throwing an extra pile of fake pro-Lukashenko ballots into the ballot box:

It is a hundred percent certain that all the elections since 1994 have been falsified to a various extent. During the latest election, a rumor dominated in the intellectual and expert circles that voters were now not even needed for falsification: while before the ballots were changed at night, at one point this became unnecessary. What they did was filling out the protocol at the polling station in pencil and, on the way to the district election commission, writing in necessary numbers with a pen. Somewhere the falsifications happened this way, somewhere - through a throw-in. There were comic cases too: the commission puts up a protocol, suddenly someone who is not even in the commission runs by, tears the protocol away, and the next day a new protocol is put up, but with completely different numbers. I am not saying that this happened everywhere, but there is a system and 
there is a task, and if you do not complete it-you are doomed. How you complete it is decided by the local governor, and there are certain useful well-developed schemes I have mentioned for that. To change the bulletins at night or to fill out the results in pencil.

(Recorded from a 27-year-old male in Minsk, 2012)

The electoral frauds described in the interview above represent cases of direct purposeful falsification. Another type of fraud described is associated with misunderstanding the system due to the lack of comprehensive explanation of how the election organization works. This is not understood as illegal fraud, but as a defect of the system, which nevertheless benefits the president:

As far as I know, if 40 people out of 100 vote "none of the above", we lose these 40 votes. As far as I know, I was told: these 40 votes are given to the one who was in power before. And we had had only one person in power before. (Recorded from an 18-year-old male in Vitebsk, 2012)

I consider that the high percentage of voters for Lukashenko was achieved by taking advantage of the villages. For instance, when there was a referendum [to allow Lukashenko to change the constitution and become a candidate for an unlimited number of terms], I do not remember how the question was formulated, but it was said that the referendum was about extending Lukashenko's presidential term. Elderly people did not understand the question. They thought that Lukashenko was being impeached or something, not that the constitution would be changed. People just did not understand the question: it was posed too slyly.

(Recorded from a 45-year-old female in Vitebsk, 2013)

Election fraud has become a topic for many jokes in general. For instance, the aforementioned social network group publishing in the name of Lukashenko's son, Kolen'ka, has many of them (see Vk.com 2015):

I was exploring daddy's table and found the results of the 2015 election. They are quite ok. I think daddy will like them. (June 26)

My hand is so tired of ticking off the ballots. (October 11)

I understood that daddy would definitely win, as he had ordered to bring 200 tubes of correction fluid to the election stations. (October 11)

Why the hell are the sacks with ballots supposed to be kept in my room? (October 11) 
Daddy asked me which number sounded more credible: $79 \%$ or $86 \%$. (October 11)

Daddy explained what the secret of his success was. It turned out that one vote for him is counted for two... million. (August 3)

Conversational jokes on this topic are also frequent in the interviews. The following piece, for instance, was labeled by the interviewee as a joke: "I have a friend, who has a friend. So his acquaintance knows someone who voted for Lukashenko" (recorded from a 32-year-old male in Minsk, 2012). The humorous genre, however, is hardly discernible from belief narratives occurring in other interviews, marking the incongruence between perceptions about the elections and the official results announced by the state. The following example, for instance, touches upon the same topic - the disbelief in the election results caused by the fact that only few acquaintances of the interviewee voted for Lukashenko:

The elections were falsified. I have not counted myself, but I consider it to be so. Out of my environment only a few mentioned that they voted for Lukashenko. That is why I consider the elections to be falsified.

(Recorded from a 20-year-old male in Vitebsk, 2012)

The counter-discourse of conspiracy and rumor was undoubtedly supported by anti-Lukashenko opposition in their press, but, as it often happens, it shaped a strong commitment to the perception that the elections were no longer a secure means of displaying public opinion (Rahimi 2013: 83). Since 2011, I have recorded more than 100 texts of Belarusian political jokes, and many of them touch upon this mistrust, even in between the elections. For instance, the fourth most popular joke in my collection is about the general election; a version of it presented below was recorded in December 2012, two years after the presidential election. The same joke is told in Russia about Putin winning the election over Sarkozi and Obama (Livejournal 2012).

Obama, Putin, and Lukashenko get on a desert island, but find a boat there. Nobody wants to row. Obama says, "Nation... The US is a great nation, I am the president of the great nation, I am not going to row." Putin says, "Mmm... Russia is a powerful country, I am the president, I am not going to row." Finally Lukashenko says, "Let's conduct elections then." And then the picture changes to what happens in two hours: Obama rows one paddle and Putin rows the other. Putin says to Obama, "Listen, we are three, how did it happen that two voted for you to row and another two for me to row?" (Recorded from a 35-year-old male in Tallinn, 2012) 
Another popular joke tells about Lukashenko being invited to Venezuela (alternatively, the United Sates or Russia) to help the leaders with organizing an election - and winning their election himself (recorded from a 27-year-old female in Vitebsk, 2013). Finally, the Belarusian jokes also employ the recurrent frame of three characters coming to see God:

Once God invited three presidents to the heaven: those of the United States, Russia, and Belarus; and he says to them: "Dear presidents, I have invited you to announce unpleasant news: the doomsday is coming in two weeks. I want you to inform my three favorite peoples about it in a dignified way".

The statement of Bill Clinton on the radio and TV: "Brothers and sisters, I have two pieces of news for you: a good one and a bad one. The good one is that God exists. The bad one is that the doomsday is coming in two weeks".

The statement of Boris Yeltsin on the radio and TV: "Ladies and gentlemen, I have two pieces of news for you. Both are bad. The first one is that God exists. The second one is that the doomsday is coming in two weeks".

The statement of Lukashenko on the radio and TV: "People of free Belarus, I have two pieces of news for you. The first one: God acknowledged that I am the president. The second one: I am going to rule till the doomsday”. (Recorded from a 25-year-old female in Tartu, 2013)

Although in this article I strive to show the interconnection and indiscernibility of election folklore genres and themes from each other, it is also obvious that general rumors and humor about pro-Lukashenko election fraud also have distinct and recurrent motifs.

\section{GLADIATORS FOR LUKASHENKO}

In his research on Central Asian post-Soviet elections, Donnacha Ó Beacháin links their peculiarities to other non-democratic regimes, saying: "Thus, rather than one candidate emerging as a serious challenger, the vote is relatively evenly divided between the contenders so that the margin between incumbent and loser is overwhelming" (Ó Beacháin 2011: 218). He compares the role of the contenders to that of the warm-up gladiatorial acts of old, providing an opponent for the star of the stage and dying gracefully before the public view (ibid.: 223). This product of the communist past combined with the communisttrained present (ibid.: 224) is also undoubtedly the case of Belarus, where, according to the results of the presidential election, the alternative candidates 
receive an extreme minimum of voices. Little wonder that there is plenty of vernacular joking on that:

Ulakhovich [an alternative candidate in the 2015 election] and his wife voted at one of the election stations. The first vote for Ulakhovich! (Twitter 2015)

Kolen'ka's posts (Vk.com 2015):

The wife of Ulakhovich refused to vote for her husband, now he has twice fewer votes. (October 11, 2015)

I offered daddy to vote for Karatkevich. We laughed for about 5 minutes. (October 11, 2015)

At every election, however, there is a leading candidate among the alternative ones, receiving somewhat more votes than the others. He or she becomes the protagonist of election folklore along with Lukashenko, as it happened to Tatiana Karatkevich in the previous joke. Tatiana Karatkevich, the first female presidential candidate in Belarus, gained the official result of $4.44 \%$ votes a majority after Lukashenko. Her relative popularity, soft oppositionness, and active campaign attracted plenty of attention, and also condemnation. According to many rumors, Karatkevich was a project of the KGB, a candidate created to fake democracy and honest election in Belarus. These rumors were spread by her political opponents, also oppositionists, reluctant to unite around her as an alternative candidate and condemning her activity. As I noted, plenty of negativity originated from the oppositionists in exile - political refugees who themselves were unable to participate in Belarusian politics. The logic is well explained by one Facebook status: "The General Consulate of Belarus in ... did not include me in their election commission. So will they falsify the election results?" Forbidden to participate in the Belarusian political system, they often denounce those who are allowed to do it, by definition reproducing the illegal system. "KGB hire" (statystka ad KDB), "political fake" (palitychny feik), "clown" - these are only a few negative labels people attach to her on her public Facebook page (Facebook 2015). In spite of this critique from active oppositionist, Karatkevich apparently won the sympathies of many people. In accordance with other posts on her page, one of the followers wrote:

Tatiana, I voted for you, and many of my friends did (in Pinsk). 1,5 people [poltora cheloveka, a colloquial expression meaning 'very few'] of the older generation voted for Lukashenko. The reports of observers also show this. (Facebook 2015) 
Opinions about Karatkevich ranged from negative to positive, and sometimes the fact that she was female was stressed, whether seriously or jokingly undermining her ability of being a president. Political scientist Pavel Usov, for instance, claimed that Karatkevich was not ready for serious struggle due to her vulnerability - being a mother, whose child may become "a hostage in the hands of authorities" (Naviny.by 2015b). Another symptomatic attitude was expressed in Twitter posts: "Karatkevich should not be elected just because one day she will refuse to govern the country as she has nothing to wear" (Twitter 2015). These beliefs and humor point not only to the attitude towards the alternative candidates, but also to the attitude towards women and their active participation in the political life of Belarus.

\section{LOCAL ENDEAVORS AND FORCED VOTING}

In this part, I will concentrate on what is called "polling place shenanigans" the fraud of dishonest workers employed at the election to alter an honest vote (Sarvis 1998: 55). The methods of altering may be different - from changing the protocols to spoiling ballots with the 'wrong' answer, stealing votes, manipulating absentee ballots, and the so-called nursing home vote equal to absentee voting. Political operators can manipulate on a wider level, or this may be reduced to a more localized endeavor, where individuals might contend for single polling stations and precincts (ibid.: 66). Such local endeavors are the main focus of this section.

According to the interviews, local endeavors are believed to be pushed from above, and local superiors are given different instructions to follow at the election. These are primarily state organizations that may be manipulated in such a way, and one of the most common plots is related to forced voting at universities, when the students are strongly recommended to take part in preliminary vote - being intimidated or promised an extra day off.

The intimidations of students who don't go to the preliminary voting started.

In BSEU [Belarusian State Economic University], the students who vote tomorrow will get a day off on Saturday.

There are rumors in Polytechnic University that classes will be cancelled starting from Friday, so that everyone could get home on Thursday to vote. (Livejournal 2015) 
The interviews I recorded point to even more intimidation:

When ... was the class captain [at university], the dean and a tutor tried to force her to make the students vote for Lukashenko, enter the voting booths and check how they vote. She refused, and they said they would expel her and her group; they started real terror. She was scared, but Poles were visiting her at the same time and they promised to take her and the student group to Poland if they get expelled, so they should not be scared. (Recorded from a 28-year-old female in Vitebsk, 2014)

I worked for the OSCE [Organization for Security and Co-operation in Europe] during the last election, that is how I know. There were humorous cases, when an observer from the OSCE comes and a university lecturer is telling someone in the corridor how today or yesterday she made her students vote at the preliminary election. How she threatened them and so on. Why all this is needed - it is clear - to change the ballots at night. That is why he [Lukashenko] has a boost of about $25 \%$ from this preliminary vote fraud.

(Recorded from a 27-year-old male in Minsk, 2012)

Human rights activists published lists of recommendations meant for the students who were intimidated to vote at the preliminary stage of the election and/ or for Lukashenko. They recommended coming to the polling station in person only on the Election Day, an hour before it closed, and recording the threats from university officials (Livejournal 2015).

The threats by the university officials are similar to the activities of those providing luxurious food and performances at the elections. On the one hand, they themselves are also forced to do so, on the other, they do not resist these illegal practices either. This is well described by one of the interviewees:

I think that in case of power domineering, there are always cases of election falsification, even in case there is no central directive to do that. There are always people at their places who want to curry favor [vysluzhitsya] or understand that this power is beneficial for them.

(Recorded from a 30-year-old male in Minsk, 2013)

The illegality of many election practices, such as forced - often on a local level preliminary voting, conspiracy theories, such as Karatkevich being a KGB project, and general disillusionment in the system brought oppositionists to call for a boycott of the election. According to many, the votes of those who did not come to the election station presumably cannot be falsified. But as soon as one votes, the vote goes to Lukashenko: 
All the authorities need is that people come and throw a piece of paper today; then it is a matter of skills. I am not going and hundreds of my acquaintances in Belarus will not. No reason.

(Facebook status of one of my friends, 2015)

Rumors become not just repertoires of discontent, but also rhetorical strategies (Rahimi 2013: 85-86). According to many social network posts, neither their authors nor their families will "participate in legitimizing the regime" and in "playing shell game with the power". Others recognize that even though there are cases of fraud, they are not determinative, as the majority votes for Lukashenko anyway.

Still, boycott of the election pushed through the Internet in Belarus gradually replaces open protests that become less and less frequent. Since the late 1980s Belarusian protests had their distinctive forms and dates. Among others, sanctioned and unsanctioned meetings have been held on the so-called Dziady, a day in the autumn, when ancestors are traditionally commemorated in Belarus. Rejected during the Soviet times, in independent Belarus this date acquired a new meaning - commemorating the victims of the Soviet power as a means of constructing Belarusian identity independent from, if not hostile to, Russian influence. Also, protests used to accompany every election too, although now it happens less and less often. First, recent post-election protests were too violently suppressed, with many beaten and arrested. Many of the previous years' election candidates were imprisoned, and the protests lost their leaders. Belarusian political attitudes were largely influenced by the Ukrainian example; it is often repeated now that revolution and resistance lead to war. Finally, many oppositionists and their followers are just tired of unsuccessful attempts with no possibility of change. As a result, the 2015 election, with one of the highest results for Lukashenko in his presidential history, brought together only several hundred protesters (Svaboda 2015). Both in Iran and in Belarus, the protests are transferred to the internet discussions and speculations, "where subaltern voices gain the opportunity to articulate and, through networking, interactively define a world upside-down, [questioning] authority and the claims to authenticity of a political order" (Rahimi 2013: 91). Unable to participate in political processes otherwise, the opponents of Lukashenko now rather post their opinions on the Internet and disseminate rumors through this. The call for action is now not about the general protest, but on the Internet, about boycotting the elections. 


\section{GENRE INTERPLAY}

The election fraud rumors "can have varying degrees of substance and sensation" (Sarvis 1998: 43), becoming a mixture of direct testimony and legendary accounts (ibid.: 45). Another mixture I have already mentioned is that of different generic expressions. It is not only that election rumors, based on traditional themes and modern motifs, can also easily fall into the categories of contemporary legends, conspiracy theories, or even gossip. As shown above, sometimes it is even hard to distinguish between a joke and a rumor, and there are even more cases when jokes are not understandable without the knowledge of rumor, or they employ similar themes.

Humor and rumor intertwine so often that scholars even have to search for the boundaries between seriously presented truth claims and practical jokes directed at an audience (Ciardy 1965: 18; Fine \& Ellis 2010: 125-127; Bennett 1988, 1993). The same narratives may be equally used for both purposes: to raise a laugh and to recommend others to be alert. Similar to rumors, jokes provide a vent for frustration and an outlet for emotions (Banc \& Dundes 1986: 10; Dundes 1971: 51), if not become a "tiny revolution" (Orwell 1945: 1) and the weapon of the weak (Scott 1985). As Linda Dégh proves, the jokes and legends do not only get well together: they also provide necessary living conditions for each other (Dégh 1995: 293).

In the Belarusian case, jokes serve as a means for seriously probing and potentially debating a group's fears voiced in the rumors.

This case of ambiguity is obviously not unique, as "all genres leak" (Briggs \& Bauman 1992: 149), and there is no need not to make strict distinctions between different texts. Yet, it is important to look at the practices used in creating intertextual relations with other bodies of discourse (ibid.: 147, 163). Intertextuality is a dialogue among several writings, a relationship between a particular text and a prior discourse (ibid.: 147). Reproducing the power system, and talking and laughing about it, are all intertextually connected in Belarusian political discourse, providing powerful means for national and political identity constructions. Whether characterized as jokes or rumors, Belarusian election folklore becomes a flexible product of an ongoing struggle for making sense of the situation. Both rumors and jokes become instrumental in shaping and negotiating the attitude to the situation. As Timothy Tangherlini argues, and this can be applicable to jokes too, it is the indeterminate and fluid nature of [group] ideology that requires group members to tell stories to each other to confirm, define, and shape it. As such, the telling of a rumor should be considered a deeply political act. These stories are also deployed to sway others' actions, according to the narrator's own goal (Tangherlini 2007: 7-8). 
Tangherlini's arguments are well illustrated by the modality that Belarusian oppositionists have for spreading the rumors and the cases of misunderstanding the system due to the lack of comprehensive explanation of how the election system works. In turn, based on Missouri postwar election accounts, Sarvis suggests that when we do not know what is normal and what is not, it gives rise to the atmosphere of suspicion, and, as a result, to a rich oral tradition (Sarvis 1998: 46). Applicable to the Belarusian situation, the lack of knowledge about what is legal or normal and what is not, what is fraud or potential fraud or what is not, the absence of official information, rules, and accountability produces plenty of questions and consequent vernacular theorizing, as my own experience of voting in the Belarusian embassy did. The complexity of the system and the lack of answers also engender skepticism and irony. The multiplicity of intertextual links and generic precedents results in mixed, blurred, ambiguous, and contradictory generic framings (Briggs \& Bauman 1992: 163). The fieldwork data from Belarus enables us to theorize about genres and their interrelationships in practice.

\section{CONCLUSION}

The potential of multiple voting, wherein a single voter could travel from precinct to precinct, casting as many ballots as possible on Election Day (Sarvis 1998: 42), was possible in some American states until recently and became one of the rich sources of the election fraud folklore. Multiple voting seems to be still possible in the twenty-first century Belarus, and many more narratives tell about other possibilities of sham and fraudulent election in the country. A mixture of direct testimony, legendry accounts, and irony over the whole situation emerges in the interplay of jokes, news, and rumors. As fieldwork records show, the borders between these genres do not only fluctuate; they become almost irrelevant. Instead, intertextual connections of these texts persist, also reproducing the power system. Whether rumors about Potemkinism or jokes, the Belarusian election folklore becomes an expression of paternalist culture and a ritualistic demonstration of loyalty, even when it is mocked at. A very similar situation has been described for the Soviet Minsk 1950s election (Bohn 2011: 317), and, after half a century, many of its elements have been preserved to a large extent. The rumors and jokes related to elections usually combine various other significant tensions existing in the society. They circulate in the country all the time, not necessarily around the time of election (many were recorded in the interviews in the period between elections). On the one hand, 
they reproduce distinct themes, on the other, election fraud practices, according to the accounts, often overlap with one another. The gap between reality and the official rhetoric with its democratic façade is too stark, and the experiencebased folk expressions around the election become intertextual bridges that bring two sides together, whether to make sense of the disparity or to laugh at it.

\section{ACKNOWLEDGEMENTS}

This research was supported by Institutional Research Project "Tradition, Creativity, and Society: Minorities and Alternative Discourses" (IUT 2-43).

\section{RECORDINGS}

Recordings of interviews conducted in 2011-2015 in possession of the author.

\section{REFERENCES}

Alekseevsky 2010 = Alekseevskii, Mikhail. Anekdoty ot Ziuganova: Fol'klor v sovremennoi politicheskoi bor'be. [Jokes from Zuganov: Folklore in Contemporary Political Struggle.] Antropologicheskii forum onlain, No. 12. Available at http:// anthropologie.kunstkamera.ru/files/pdf/012online/12_online_alekseevsky.pdf, last accessed on May 29, 2017.

Andrews, Molly 2012. What is Narrative? Connecting Micro and Macro Political Stories. Novella. Available at http://www.novella.ac.uk/documents/Connecting_Micro_ and_Macro_Political_Stories.pdf, last accessed on May 22, 2017.

Arkhipova, Aleksandra 2012. Anekdoty o Putine i vyborakh 10 let spustia, ili est' li fol'lor "Snezhnoi revoliutsii"? [Jokes about Putin 10 Years Later, or Does the Folklore of "Snow Revolution" Exist?] Antropologicheskii forum onlain, No. 16, pp. 208-252. Available at http://anthropologie.kunstkamera.ru/files/pdf/016online/arkhipova2. pdf, last accessed on May 29, 2017.

Arkhipova \& Alekseevsky 2014 = Arkhipova, Aleksandra \& Alekseevskii, Mikhail (eds.) My ne nemy. [We Are Not Dumb.] Tartu: Nauchnoe izdatel'stvo ELM.

Astapova, Anastasiya 2015. When the President Comes: Potemkin Order as an Alternative to Democracy in Belarus. Negotiating Belarusianness: Political Folklore Betwixt and Between. Dissertationes Folkloristicae Universitatis Tartuensis 22. Tartu: University of Tartu Press, pp. 1-23. 
Attardo, Salvatore \& Raskin, Victor 1991. Script Theory Revis(it)ed: Joke Similarity and Joke Representation Model. Humor: International Journal of Humor Research, Vol. 4, Nos. 3-4, pp. 293-347. http://dx.doi.org/10.1515/humr.1991.4.3-4.293.

Banc, C. \& Dundes, Alan 1986. First Prize: Fifteen Years! An Annotated Collection of Romanian Political Jokes. Rutherford, N.J.: Fairleigh Dickinson University Press.

Bekus, Nelly 2010. Struggle over Identity: The Official and the Alternative "Belarusianness". Budapest: Central European University Press.

Bennett, Gillian 1988. Legend: Performance and Truth. In: Gillian Bennett \& Paul Smith (eds.) Monsters with Iron Teeth: Perspectives on Contemporary Legend III. Sheffield, UK: Sheffield Academic Press, pp. 13-36. Available athttp://collections.mun.ca/PDFs/ clegend/MonsterswithIronTeethPerspectivesonContemporaryLegendVol.03.pdf, last accessed on May 29, 2017.

Bennett, Gillian 1993. The Color of Saying: Modern Legend and Folktale. Southern Folklore, No. 50, pp. 19-32.

Blacker, Coit \& Rice, Condoleezza 2001. Belarus and the Flight from Sovereignty. In: Stephen D. Krasner (ed.) Problematic Sovereignty: Contested Rules and Political Possibilities. New York: Columbia University Press, pp. 224-250.

Bohn, Thomas M. 2011. "The People's Voice": The Elections to the Supreme Soviet of the USSR in 1958 in the Belarusian Capital Minsk. In: Ralph Jessen \& Hedwig Richter (eds.) Voting for Hitler and Stalin: Elections Under 20th Century Dictatorships. Frankfurt \& New York: Campus Verlag, pp. 309-336.

Briggs, Charles L. \& Bauman, Richard 1992. Genre, Intertextuality, and Social Power. Journal of Linguistic Anthropology, Vol. 2, No. 2, pp. 131-172. DOI: 10.1525/ jlin.1992.2.2.131.

Bugrova, Irina 1998. Politische Kultur in Belarus: Eine Rekonstruktion der Entwicklung vom Groß-fürstentum Litauen zum Lukaschenko-Regime. Mannheim: FKKS. Available at http://fkks.uni-mannheim.de/publikationen/fkks18.pdf, last accessed on May 29, 2017.

Ciardy, John 1965. Manner of Speaking. Saturday Review, November 27, p. 18.

Davis, John (ed.) 2013. The Arab Spring and Arab Thaw: Unfinished Revolutions and the Quest for Democracy. Farnham: Ashgate.

Dégh, Linda 1994. American Folklore and the Mass Media. Bloomington \& Indianapolis: Indiana University Press.

Dégh, Linda 1995. Symbiosis of Joke and Legend: A Case of Conversational Folklore. In: Linda Kinsey Adams (ed.) Narratives in Society: A Performer-Centered Study of Narration. FF Communications No. 255. Helsinki: Academia Scientiarum Fennica, pp. 285-305.

Dinkin, Robert J. (ed.) 2002. Election Day: A Documentary History. Westport, CT: Greenwood Press.

Dundes, Alan 1971. Laughter behind the Iron Curtain: A Sample of Rumanian Political Jokes. Ukrainian Quarterly, No. 27, pp. 50-59.

Erpyleva, Svetlana \& Magun, Artemi (eds.) 2014. Politika apolitichnykh: grazhdanskie dvizheniia $v$ Rossii 2011-2013. [The Politics of the Apolitical: The Civil Movements in Russia 2011-2013.] Moscow: Novoe literaturnoe obozrenie. 
Fabre, Genevieve 1993. Election Day Celebrations. In: Wolfgang Binder (ed.) Slavery in the Americas. Würzburg: Königshausen \& Neumann, pp. 403-420.

Fine, Gary Alan \& Ellis, Bill 2010. The Global Grapevine: Why Rumors of Terrorism, Immigration, and Trade Matter. Oxford: Oxford University Press.

Gamber, Wendy, \& Grossberg, Michael \& Hartog, Hendrik (eds.) 2003. American Public Life and the Historical Imagination. Notre Dame: University of Notre Dame Press.

Gencarella, Stephen Olbrys 2010. Gramsci, Good Sense, and Critical Folklore Studies: A Critical Reintroduction. Journal of Folklore Research, Vol. 47, No. 3, pp. 259264. http://dx.doi.org/10.2979/jfolkrese.2010.47.3.259.

Goldstuck, Arthur 1994. Ink in the Porridge: Urban Legends of the South African Elections. London: Penguin.

Granberg, Donald \& Burlison, James 1983. The Abortion Issue in the 1980 Elections. Family Planning Perspectives, Vol. 15, No. 5, pp. 231-238. http://dx.doi. org/10.2307/2135282.

Hermet, Guy \& Rose, Richard \& Rouquié, Alain 1978. Elections without Choice. London: Palgrave McMillan.

Honari, Ali 2014. From Virtual to Tangible Social Movements in Iran. In: Paul Aarts \& Francesco Cavatorta (eds.) Civil Society in Syria and Iran: Activism in Authoritarian Contexts. Boulder, CO: Lynne Rienner, pp. 143-168.

Jessen, Ralph \& Richter, Hedwig 2011. Non-Competitive Elections in 20th Century Dictatorships: Some Questions and General Considerations. In: Ralph Jessen \& Hedwig Richter (eds.) Voting for Hitler and Stalin: Elections Under 20th Century Dictatorships. Frankfurt \& New York: Campus Verlag, pp. 9-38.

Kamalipour, Yahya R. 2010. Media, Power, and Politics in the Digital Age: The 2009 Presidential Election Uprising in Iran. Lanham: Rowman \& Littlefield.

Kaschula, Russell H. 2004. Southern Africa: Contemporary Forms of Folklore. In: Philip M. Peek \& Kwesi Yankah (eds.) African Folklore: An Encyclopedia. New York \& London: Routledge, pp. 866-870.

Koestler, Arthur 1964. The Act of Creation. London: Hutchinson.

Korosteleva, Elena \& Lawson, Colin \& Marsh, Rosalind 2003. Afterword: The Presidential Election of September 2001. In: E. Korosteleva \& C. Lawson \& R. Marsh. Contemporary Belarus: Between Democracy and Dictatorship. London \& New York: Routledge, pp. 193-196.

Kozlov, Vladimir \& Mironenko, Sergei (eds.) 2005. Kramola: Inakomyslie v SSSR pri Khrushcheve i Brezhneve 1953-1982 gg. Rassekrechennye dokumenty Verkhovnogo suda i Prokuratury SSSR. [Revolt: Dissidence in Russia in the Era of Khruschev and Brezhnev 1953-1982. Declassified Documents of the USSR Public Prosecutor's Office.] Moscow: Materik.

Latvala, Pauliina 2014. On Election Day the Husband Tied His Wife to a Table Leg to Stop Her from Voting: Political Narratives, Gender and Archived Heritage in Finland. Folklore: Electronic Journal of Folklore, No. 57, pp. 117-140. http:// dx.doi.org/10.7592/FEJF2014.57.latvala.

Merl, Stephan 2011. Elections in the Soviet Union, 1937-1989: A View into a Paternalistic World from Below. In: Ralph Jessen \& Hedwig Richter (eds.) Voting for Hitler and Stalin: Elections Under 20th Century Dictatorships. Frankfurt \& New York: Campus Verlag, pp. 276-308. 
Muravchik, Joshua 2013. Trailblazers of the Arab Spring: Voices of Democracy in the Middle East. New York \& London: Encounter Books.

Ó Beacháin, Donnacha 2011. Faking It: Neo-Soviet Electoral Politics in Central Asia. In: Ralph Jessen \& Hedwig Richter (eds.) Voting for Hitler and Stalin: Elections Under 20th Century Dictatorships. Frankfurt \& London: Campus Verlag, pp. 204-230.

Oring, Elliott 2004. Risky Business: Political Jokes under Repressive Regimes. Western Folklore, Vol. 63, No. 3, pp. 209-236. Available at https://www.jstor.org/ stable/25474676?seq=1\#page_scan_tab_contents, last accessed on May 29, 2017.

Orwell, George 1945. Funny, But Not Vulgar. Leader, July 28.

Patterson, Thomas E. 2003. The Vanishing Voter: Public Involvement in an Age of Uncertainty. New York: Vintage Books.

Patzelt, Werner J. 2011. Elections in Modern Dictatorships: Some Analytical Considerations. In: Ralph Jessen \& Hedwig Richter (eds.) Voting for Hitler and Stalin: Elections Under 20th Century Dictatorships. Frankfurt \& London: Campus Verlag, pp. 126-145.

Pound, Louise 1959. Nebraska Folklore. Lincoln: University of Nebraska Press.

Rahimi, Babak 2013. The Politics of Informal Communication: Conspiracy Theories and Rumors in the 2009 (Post-)Electoral Iranian Public Sphere. In: Greg Dalziel (ed.) Rumor and Communication in Asia in the Internet Age. London \& New York: Routledge, pp. 78-93.

Richter, Hedwig 2011. Mass Obedience: Practices and Functions of Elections in the German Democratic Republic. In: Ralph Jessen \& Hedwig Richter (eds.) Voting for Hitler and Stalin: Elections Under 20th Century Dictatorships. Frankfurt \& London: Campus Verlag, pp. 103-125.

Rudling, Per Anders 2015. The Rise and Fall of Belarusian Nationalism, 1906-1931. Pittsburgh, PA: University of Pittsburgh Press.

Santino, Jack 1994. All Around the Year: Holidays and Celebrations in American Life. Urbana \& Chicago: University of Illinois Press.

Sarvis, William R. 1998. The Folklore and Oral History of Election Fraud in Rural Postwar Missouri. Mid-America Folklore, Vol. 26, Nos. 1-2, pp. 42-70.

Savchenko, Andrew 2009. Belarus - A Perpetual Borderland. Leiden: Brill Academic Publishers.

Schudson, Michael 1998. The Good Citizen: A History of American Civic Life. New York: The Free Press.

Scott, James C. 1985. Weapons of the Weak: Everyday Forms of Peasant Resistance. New Haven: Yale University Press.

Scott, James C. 1990. Domination and the Arts of Resistance: Hidden Transcripts. New Haven and London: Yale University Press. Available at https:/libcom.org/files/ scott_dominationandresistance.pdf, last accessed on May 30, 2017.

Tangherlini, Timothy R. 2007. Rhetoric, Truth, and Performance: Politics and the Interpretation of Legends. Indian Folklife: A Quarterly Newsletter from National Folklore Support Centre, Vol. 25, pp. 8-12. Available at http://tango.bol.ucla.edu/ publications/A73.pdf, last accessed on May 29, 2017. 
Tsipursky, Gleb 2011. Integration, Celebration, and Challenge: Soviet Youth and Elections, 1953-1968. In: Ralph Jessen \& Hedwig Richter (eds.) Voting for Hitler and Stalin: Elections Under 20th Century Dictatorships. Frankfurt \& London: Campus Verlag, pp. 81-102.

Varga, Katalin 2015. Creativity and Humor in the Online Folklore of the 2014 Political Elections in Hungary. Folklore Fellows Summer School 2015. Oral presentation.

Watts, Linda S. 2006. Election Day. In: Linda S. Watts. Encyclopedia of American Folklore. New York: Facts On File, pp. 125-126.

Weddady, Nasser \& Ahmari, Sohrab (eds.) 2012. Arab Spring Dreams: The Next Generation Speaks Out for Freedom and Justice from North Africa to Iran. New York: Palgrave MacMillan.

White, Joyce M. 1993. Meaning and Cultural Expression: New England Election Day Cake. Digest: A Review for the Interdisciplinary Study of Food, Vol. 13, Nos. 1-2, pp. 9-15.

Yurchak, Alexei 1997. The Cynical Reason of Late Socialism: Power, Pretense, and the Anekdot. Public Culture, Vol. 9, No. 2, pp. 161-188. DOI: 10.1215/08992363-9$2-161$.

Zaslavsky, Victor \& Brym, Robert J. 1978. The Functions of Elections in the USSR. Soviet Studies, Vol. 30, No. 3, pp. 362-371. http://dx.doi.org/10.1080/09668137808411193.

\section{INTERNET SOURCES}

BBC News 2001 = Belarus Vote 'Neither Free nor Fair'. BBC News, September 10. Available at http://news.bbc.co.uk/2/hi/europe/1534621.stm, last accessed on May 30, 2017.

BBC News 2006 = Belorussiia: 1994-2006 [Belarus: 1994-2006.] BBC Russian.com, March 16. Available at http://news.bbc.co.uk/hi/russian/in_depth/2006/belarus/ newsid_4810000/4810062.stm, last accessed on May 30, 2017.

Facebook 2015 = Tatiana Karatkevich. Available at https://www.facebook.com/tania. karatkevich, last accessed on May 26, 2017.

Google play 2015 = Lida: Save the Elections. Available at: https://play.google.com/store/ apps/details?id=ru.lanaer.lida, last accessed on May 29, 2017.

Grodno 2015 = Bufet na prezidentskom uchastke raduet izbiratelei smeshnymi tsenami. [The Buffet at the President's Election Station Makes the Voters Happy with Its Preposterous Prices.] Grodno24, October 11. Available at http://grodno24. com/belarus/bufet-na-prezidentskom-uchastke-raduet-izbiratelej-smeshnyimiczenami.html, last accessed on May 30, 2017.

Livejournal 2012 = Tselibat, piraty i greshnye zaitsy. [Celibacy, Pirates and Sinful Hares.] Livejournal, December 1. Available at http://diak-kuraev.livejournal. com/267282.html?nojs=1\&page=2, last accessed on May 30, 2017. 
Livejournal 2015 = Nachalis' zapugivaniia studentov za neiavku na dosrochnoe golosovanie. [The Intimidations of Students Regarding No-Show for the Preliminary Voting Started.] Livejournal, October 5. Available at http://toxaby. livejournal.com/645170.html, last accessed on May 30, 2017.

Minsknews 2015 = Na izbiratel'nykh uchastkakh 11 oktiabria minchan ozhidaet massa priiatnykh siurprizoviu. [At the Election Stations on October 11 the Residents of Minsk Will Be Faced with Many Pleasant Surprises.] Minsknews, October 9. Available at http://minsknews.by/blog/2015/10/09/na-izbiratelnyih-uchastkah11-oktyabrya-minchan-ozhidaet-massa-priyatnyih-syurprizov/, last accessed on May 30, 2017.

Naviny.by $2015 \mathrm{a}=$ Vybory prezidenta Belarusi-2015: Onlain-reportazh. [The Election of the Belarusian President 2015: Online-Report.] Naviny.by, October 11. Available at http://naviny.by/rubrics/elections/2015/10/11/ic_articles_623_189997/, last accessed on May 30, 2017.

Naviny.by 2015 b = Pavel Usov. TEORIIA: Pochemu Tat'iana Korotkevich - feikovyi kandidat. [Pavel Usov. A Theory: Why Tatiana Karatkevich is a Fake Candidate.] Naviny.by, May 24. Available at: http://naviny.by/rubrics/opinion/2015/05/24/ ic_articles_410_188958/, last accessed on May 30, 2017.

Pikabu 2015 = Golosovanie prokhodit v tiazhelykh usloviiakh. [The Voting is Being Held in Hard Conditions.] Pikabu. Available at http://pikabu.ru/story/golosovanie_ prokhodit_v_tyazhelyikh_usloviyakh_3703814, last accessed on May 30, 2017.

Ru.tsn.ua $2010=\mathrm{V}$ tsentre Minska protivniki Lukashenko poprosili 'Sashu' uiti. [In the Center of Minsk the Opponents of Lukashenko asked 'Sasha' to Leave.] Ru.tsn. ua, November 24. Available at http://ru.tsn.ua/svit/v-centre-minska-protivnikilukashenko-poprosili-sashu-uyti.html, last accessed on May 30, 2017.

Svaboda 2015 = Spantannaia Ploshcha-2015: ad Kastrychnitskai da ploshchy Nezalezhnas'tsi. [Spontaneous Square-2015: From Kastrychnitskaya to Nezalezhnasc' Square.] Svaboda, October 11. Available at http://www.svaboda. mobi/a/27300520.html, last accessed on May 30, 2017.

The Central Commission 2004 = Ukaz Prezidenta Respubliki Belarus' 7 sentiabria 2004 g. N 431 g. o naznachenii respublikanskogo referenduma. [The Decree of the President of the Republic of Belarus from September 7, 2004, No. 431, about Conducting the Republican Referendum.] Available at http://www.rec.gov.by/sites/ default/files/pdf/Archive-Referenda-2004-Ukaz.pdf, last accessed on May 30, 2017.

Twitter 2015 = \#выборытут [electionhere.] Available at https://twitter.com/hashtag/\%D 0\%B2\%D1\%8B\%D0\%B1\%D0\%BE\%D1\%80\%D1\%8B\%D1\%82\%D1\%83\%D1\%82, last accessed on May 26, 2017.

United Civil Party 2015 = Sensatsiia: foto i video 'karusel'shchikov'! [Sensation! Photos and Videos of Merry-Go-Rounders!] Ob"edinennaia grazhdanskaia partiia, October 9. Available at http://ucpb.org/news/society/sensatsiya-foto-i-video-karuselshchikov, last accessed on May 30, 2017.

Vk.com 2015 = Grustnyi Kolen'ka. [Sad Kolen'ka.] Available at https://vk.com/kolyasik_ prod, last accessed on May 24, 2017. 
Youtube 2006 = Lukashenko: my sfal'sifitsirovali poslednie prezidentskie vybory. [Lukashenko: We Falsified the Latest Presidential Election.] Youtube, November 23. Available at https://www.youtube.com/watch?v=g982KGUcrKk, last accessed on May 30, 2017.

Youtube 2015 = "Ia idu na vybory, potomu chto..." ["I Am Going to the Election Because..."] Youtube, October 2. Available at https://www.youtube.com/ watch?v=TrmPuGZk2hs, last accessed on May 30, 2017. 


\title{
THE IMAGE OF THE WEST IN CONSPIRACY THEORIES IN SLOVAKIA AND ITS HISTORICAL CONTEXT
}

\author{
Zuzana Panczová \\ Institute of Ethnology \\ Slovak Academy of Sciences, Bratislava, Slovakia \\ e-mail: Zuzana.Panczova@savba.sk
}

\begin{abstract}
This paper presents one of the typical features of conspiracy theories the dualistic worldview, which explains important events as a consequence of hidden struggle between 'Us' and the dark forces. An example of this characteristic also presents the dichotomous terms 'West' and 'East', which have their set of geopolitical and cultural (as well as axiological) connotations. As a political and moral concept, 'West' is particularly highly utilised in the conspiratorial discourse in Slovakia. The paper attempts to discuss the functions of this concept in rumours and conspiracy theories with regard to the local historical context, and to reveal its ties to other images of the 'enemy', frequently used in rumours circulating on popular Slovak websites. Besides conspiracy theories as such, the focus of the analysis is set also on the narratives (among others also urban legends) supporting conspiratorial suspicions, as well as on various kinds of argumentation strategies leading to cooperation (or even fusion) of seemingly contradictory ideological worldviews (left- and right-wing supporters, Christians and white supremacists, etc.).
\end{abstract}

Keywords: alternative media, conspiracy theory, conspiratorial discourse, images of enemy, nationalism, rumour, Slovakia, West

\section{INTRODUCTION}

Conspiracy theories as a specific kind of rumour-based statements are interesting objects of research in social science because of their impact on group beliefs and acting. They often create specific narratives or narrative schemes with established topics and cycles, their contents spread mostly spontaneously through the 'conduits' of supporters and produce a complex system of conspiracy culture. Therefore, they are perceived as an interesting object of research also for contemporary folklore or narrative studies.

Conspiracy theories as an established type of public discourse in Slovakia are currently experiencing their peak period. In the framework of my ethnological 
and folkloristic specialisation, I have studied conspiracy theories as an ideological type of rumours based both on the current topics of social discourse and on handed-down images of the enemy.

The typical features of conspiracy theories have been summarised by many authors, among them Michael Barkun, who in his well-known work about the culture of conspiracy presents three basic characteristics:

Nothing happens by accident. Conspiracy implies a world based on intentionality, from which accident and coincidence have been removed. Anything that happens occurs because it has been willed...

Nothing is as it seems. Appearances are deceptive, because conspirators wish to deceive in order to disguise their identities or their activities. Thus the appearance of innocence is deemed to be no guarantee that an individual or group is benign.

Everything is connected. Because the conspiracists' world has no room for accident, pattern is believed to be everywhere, albeit hidden from plain view. Hence the conspiracy theorist must engage in a constant process of linkage and correlation in order to map the hidden connections. (Barkun 2013: 3-4)

Even though the beginnings of focused scientific and mass media reflections of conspiracy theories date back to the first years of the twenty-first century, it is not a completely new phenomenon. Distrust in the governing system, dissatisfaction with the current policies, changes in society, and fears from internal and external enemies (intensified mainly in the atmosphere of war conflicts) have encouraged the dissemination of (un)founded suspicions of conspiracies for centuries. ${ }^{1}$

Some experts have also observed the existence of certain contemporary trends. Véronique Campion-Vincent highlights the shift "from evil others to evil elites". According to her, "rumours accusing elites of sinister plots are not new, but they are more prominent, and especially more pervasive and complex, today" (Campion-Vincent 2005: 107). Together with Peter Knight she affirms that today's narratives "have become all-encompassing", reducing the gap between Them and Us (Campion-Vincent 2005: 109; Knight 2002: 5). In addition, Campion-Vincent highlights the changes of the impacts of these stories on society: "Extremists' views are ancient. What is new is the echo that stories of conspiracy theorists produce in the general public today" (CampionVincent 2005: 113).

Conspiratorial narratives elaborate on explanations of social phenomena as consequences of secret conspiracies, present images of enemies, traitors, and heroes. They are usually based on a bipolar perception of social processes deter- 
mined by the fight for power. This creates an ideal space for the production of ideological collages interconnecting topics from politics, religion, science or medicine.

At present, the most successful channel for the dissemination of conspiracy theories is the alternative internet media with the mainstream media as their discursive counterpart. ${ }^{2}$ Research on rumours and urban legends confirm their important role in the social organisation of trust: "In one sense, the presence of rumour reveals weakened trust in institutions" (Fine \& Ellis 2010: 111). When information from authoritative sources is considered untrustworthy and institutions are perceived as "deceptive, incompetent, and/or immoral", the facts are learned from alternate means (ibid.).

If we look at the trends in the topics of dozens of alternative conspiracysoaked media in Slovakia (with websites as the most available type of news sources), we can see that what stands out is articles that develop their theories on the basis of the division of powers into the East and the West. These terms, apart from their geographical meaning, also entail political and moral connotations. The public discourse of the last two years has been marked by the recent political events (the civil war in Ukraine, the war in Syria, the refugee crisis, terrorist attacks in Western Europe, etc.). In their interpretation of these events, the alternative news sources declare their efforts to balance out the allegedly unilateral pro-Western orientation of the mainstream media, depicting the policy of the West as the actual source of these crises and catastrophes.

In this paper, I aim to outline my efforts to seek the historical roots of this type of representations, assuming that many conspiratorial interpretations of the recent events are based on handed-down ethnic group images and stereotypes of Us and Them. Actual research on conspiracy beliefs indicates that "people are more likely to entertain as possibly true beliefs with which they are familiar and which they know are fairly widespread" (Crocker et al. 1999). I will demonstrate the issues mentioned above on the basis of sources reflecting both contemporary and historical discourses (actual news and discussions on the Internet, the nineteenth and twentieth century literature and press). This paper relates to the Slovak political and cultural context, although it is clear that this context can be very similar to the realities of other countries as well.

\section{THE IMAGE OF THE WEST IN THE CURRENT CONSPIRATORIAL DISCOURSE IN SLOVAKIA}

From the psychological perspective, conspiracy theories can be viewed also as specific verbal expressions of enmification (a term used by Rieber and Kelley (1991)), psychological factors leading to the process of 'enemy making'. 
Enmification develops through the psychological processes of stereotyping, selective perception, mirror-imaging of the enemy, dehumanization, biased attributions, attribution errors, and the psychological need to have an enemy (Fabick 2007: 74).

The image of the West as the source of conspiracy activities against Us (the nation) is sometimes interpreted as an effort to shift responsibility for (real or fabulated) negative phenomena and threats from the inside out onto the external enemy (Šebej \& Vašečka \& Nič 1998). On the other hand, the success of conspiracies depends on the actions of the 'internal enemy', an agent that disrupts our ideal world and manages to cross the border between Them and Us, unnoticed. Henri Zukier has described it as follows:

Conspirators, as the product and agents of a rupture in group solidarity, are typically internal rather than external enemies, who undermine society from within. International conspiracies are contrived within the bound of the land. The conspiracies reach far out, but unfold in the immediate proximity. The plots are hatched by strangers to society, but not by foreigners... (Zukier 1987: 99)

From the perspective of the political struggle, an important role in the construction of the story is played not so much by the conspiracy centre outside (because this is an unquestioned fact), but by its 'extended hands' - internal traitors, accomplices, and collaborators. It is them who are supposed to be the target: although physically easily reachable, the fight against them requires special public support. ${ }^{3}$ In anti-Western rhetoric, this refers to the 'henchmen of the West' or the 'cronies of Brussels', whose networks are spread mainly by pro-liberal non-profit organisations, 'homolobby', or - in the slang of internet debates - manipulated and naïve 'sunpeople' (slniečkári in Slovak).

Over the past two years, the events related to the political crisis in Syria and Ukraine, as well as the migration crisis, have been particularly reflected in Slovakia, in the narratives that had the nature of alternative news coverage, hoaxes, and conspiracy theories with a single objective - to find explanations and designate the culprits. Two opposite parties arose in the public discourse, as observed in politicians' statements, news reports, blogs, and internet debates. One of them, which we could designate as supporters of the West, defends Ukraine's efforts to join the European structures, rejects the occupation of Crimea, and usually also expresses support for help to war refugees. These attitudes are shared by the mass media considered as liberal mainstream (SME, DenníkN, ${ }^{4}$ etc.) and also by President Andrej Kiska. On the other side, there are currents of opinions refusing Slovakian membership of the European Union and NATO, the granting of asylum to refugees in Europe, and supporting Vladimir Putin's 
policy. This discourse is shared mainly by the alternative news sources (internet news websites such as Denník politika, Zem a Vek, Hlavné správy, ${ }^{5}$ etc.).

The most successful alternative media in Slovakia include the Zem a Vek magazine with Eliot Rostas as its founder and chief editor. ${ }^{6}$

In the article "Vládne nám tieňový establišment?" (Are we ruled by shadow establishment?), the image of the West is depicted as follows:

European values (often referred to by NGOs) mean one thing on the paper, and another thing in practice... What is the content of activities of uncontrollable non-governmental organisations paid by the West-so-called non-profit organisations, foundations, civic associations, institutes, etc.? If you think that it is human rights, women's rights or the rights of minorities, you are completely mistaken. These noble activities hide, in fact, cold careerism, the assumption of political and economic power accompanied by the implementation of neoliberal reforms and, especially, destruction of society in the Ukrainian way ('Maidanisation'). The parallel state that they have successfully created has its tentacles in the entire cultural sphere, and its activities include, for example, the dissemination of pro-Atlantic, neoliberal, anti-Russian, militant (officially security) propaganda against the alternative media and alternative concepts (officially called hybrid war); propaganda against the nation (artificial creation of the so-called European identity), against spirituality (mocking of believers, radical secularisation through consumption), against tradition (discontinuity), against the socialist ideas of co-operation (words like nationalisation are automatically associated with 'totalitarianism', 'lack of freedom'; this, naturally, relates to the official ideology of the unrestricted free market and neoliberalism); and against the questioning of the establishment and, in particular, for legitimisation of the establishment through all ideological structures of the system (as Noam Chomsky called them)... (Perný 2016)

In their politics-oriented agenda, alternative websites, which declare themselves Christian and present ultra-conservative and conspiracy-oriented attitudes, ${ }^{7}$ perceive the contrast between the East and the West in the apocalyptical rhetoric of the approaching open conflict. They share posts which see in Putin's Russia a source of protection of traditional values against the 'decadent West' - one of the popularly shared post is translation of the article by Patrick J. Buchanan, titled "Whose Side is God on Now?", which states, among other things: "With Marxism-Leninism a dead faith, Putin is saying the new ideological struggle is between a debauched West led by the United States and a traditionalist world Russia would be proud to lead." 
What is common to both sides is the blaming of the ideological opponents promoting foreign propaganda and, hence, conspiracy against their own nation. There are also several political studies that directly blame the Russian Federation for propaganda and the dissemination of conspiracy theories, bringing information about direct personal links between alternative media editors and Russian politicians, for example:

Russia is operating remarkable (wartime) propaganda machinery on the extreme right-wing and / or conspiratory online platforms and social media pages created in 2013 and 2014, which combine pro-Russian attitudes with conspiracy theories and anti-Western sentiments. One of the Russiafriendly media personalities is known to have close ties with the godfather of the Eurasianist ideology, Alexander Dugin. (Krekó et al. 2015: 12)

On the other hand, alternative news sources present with the same intensity theories about conspiracies by non-governmental organisations, NATO, the European Union, and the USA in provoking protests in the Ukrainian Maidan, the civil war in Syria, and the refugee crisis.

The anti-system and anti-Western rhetoric managed to combine seemingly antagonistic ideological groups - as, for example, right-wing nationalist radicalism and ultra-conservative Christian movements, ${ }^{9}$ as manifested directly during the elections to the Slovak Parliament on March 5, 2016. This cooperation was successful and thanks to the unexpectedly high number of votes, the right-wing Ludová strana - Naše Slovensko (People's Party - Our Slovakia), led by Marián Kotleba, entered the parliament for the first time.

During and after the campaign, this party was officially supported by Magnificat Slovakia (see endnote 7). This ultra-conservative party, originally aimed to promote the Marian movement (particularly apparitions of the Virgin Mary) is now focusing also on the fight against what they perceive as manifestations of the New Age movement, including freemasonry and the establishment of the New World Order. In his call to support Marián Kotleba, the founder of Magnificat, Anton Selecký, stated:

Quarter of a century after the Velvet Revolution we can notice that there has been no expected spiritual revival of the nation and economic development. On the contrary, Slovakia has lost its self-sufficiency in energy and food and its defence capability, and has become a semi-colonial outlet of foreign products. This situation is the result of external forces and treasonable activities of some domestic politicians. The only positive change was the restoration of Slovakia's independence. After economic and social destruction, our Western allies have forced us to accept moral perversion in the form of gender ideology and, lately, under the disguise 
of insidious solidarity, admit thousands of non-integrable Muslim immigrants. It is obvious today that the aim of controlled immigration is to destroy European nations and states and, in particular, the Christian roots of Europe. The invasion of immigrants continues hand in hand with the aggressive policies of the US and the West against Russia and distracts attention from them. The aim is to provoke a new global conflict, which would be beneficial mainly for the US... Let us not lose this unique opportunity. Much is at stake; it is about the survival of the Slovak Republic and of the Slovak nation, and about the future of our children. Let us decide according to our conscience, and not according to the propaganda of aggressive, hateful media or manipulated and bought election polls.

The most fervent issue in recent times that has turned the social debate in Slovakia towards a conspiracist discourse has been the issue of refugees seeking to get to Germany through the Balkans and Central Europe. The fact that the German Chancellor Angela Merkel demonstrated her willingness to admit refugees triggered a strong response among conspiracy theorists, for whom this represented a clear proof that Merkel was in the pay of conspirators who are now preparing, together with Brussels, the end of the European civilisation. ${ }^{10}$

The alternative news sources have tried to create an impression that the migrant influx is not caused by the war events in the Middle East, but that it is in fact merely a certain form of targeted efforts of the conspirators controlling global policy (USA) on Islamise Europe, undermine its traditional values and cultures, and bring about ethnic and economic destruction. In this connection, I would like to mention extremists' anti-migrant march that took place in Bratislava on June 25, 2016. Hundreds of extremists marched through Bratislava on Saturday afternoon in protest against the acceptation of what they called the "liquidation of Europe and Brussels' dictate". (A counter-protest called Anti-Fascist Mobilisation took place simultaneously with the protest of the extremists. Hundreds of people gathered there to march through the city, too.) During the march, extremists held banners reading "Together for Slovakia" and "Slovaks in Heart", and shouted slogans like "Slovakia to Slovaks", "We Don't Want Multi-Culti", and "We Are at Home Here". Marián Magát, who was running for Marián Kotleba's party in the March general election, moderated the event. In addition to Slovaks, Czechs, and Germans, Croatians and Serbs took part in the anti-migrant march. In their speeches, participants in the protest touched the issue of Brexit and expressed their interest in arranging a referendum on Slovakia's exit from the European Union. The event ended in an improvised trial of politicians (Slovak president Andrej Kiska and Prime Minister Róbert Fico) they wanted to hang. 
On the Internet, refugees have been depicted in numerous hoaxes as a threat which brings, in addition to thousands of culturally incompatible, socially dependent, uneducated, and naturally violent people, also dangerous exotic diseases (one of the internet hoaxes was about an outbreak of the West Nile fever epidemic in Vienna, illustrated by photographs of an immigrant boy with bleeding eyes, intentionally transferred from articles about a completely different type of disease - dengue fever). ${ }^{11}$ Rumours of this kind, naturally, excite public interest and support the traditional image of the 'Stranger' perceived as a kind of cultural and/or biological contamination. As summarised by Gary A. Fine and Bill Ellis (2010: 74) on examples from American narrative culture, "waves of migrants were targets of stereotypes that portrayed newcomers as the purveyors of disease, immorality, and even disloyalty". Their research points out the common tendency of anti-immigrant rhetoric to perceive immigrants as tools of the enemy's conspiracy. ${ }^{12}$ Rumours and urban legends often concentrate on depicting strangers as barbaric, immoral, nasty, and disgusting (bloodthirsty slashers, child kidnappers, animal abusers, etc.). In 2016, among many antiimmigrant hoaxes inspired by contemporary legends were particularly poignant allegations of assaults of children in Slovakia or the Czech Republic. ${ }^{13}$ As a reaction, a parody on a variant of a white (or, in this case, black) van was created and spread in the social networks in November 2015 (Fig. 1) ${ }^{14}$.

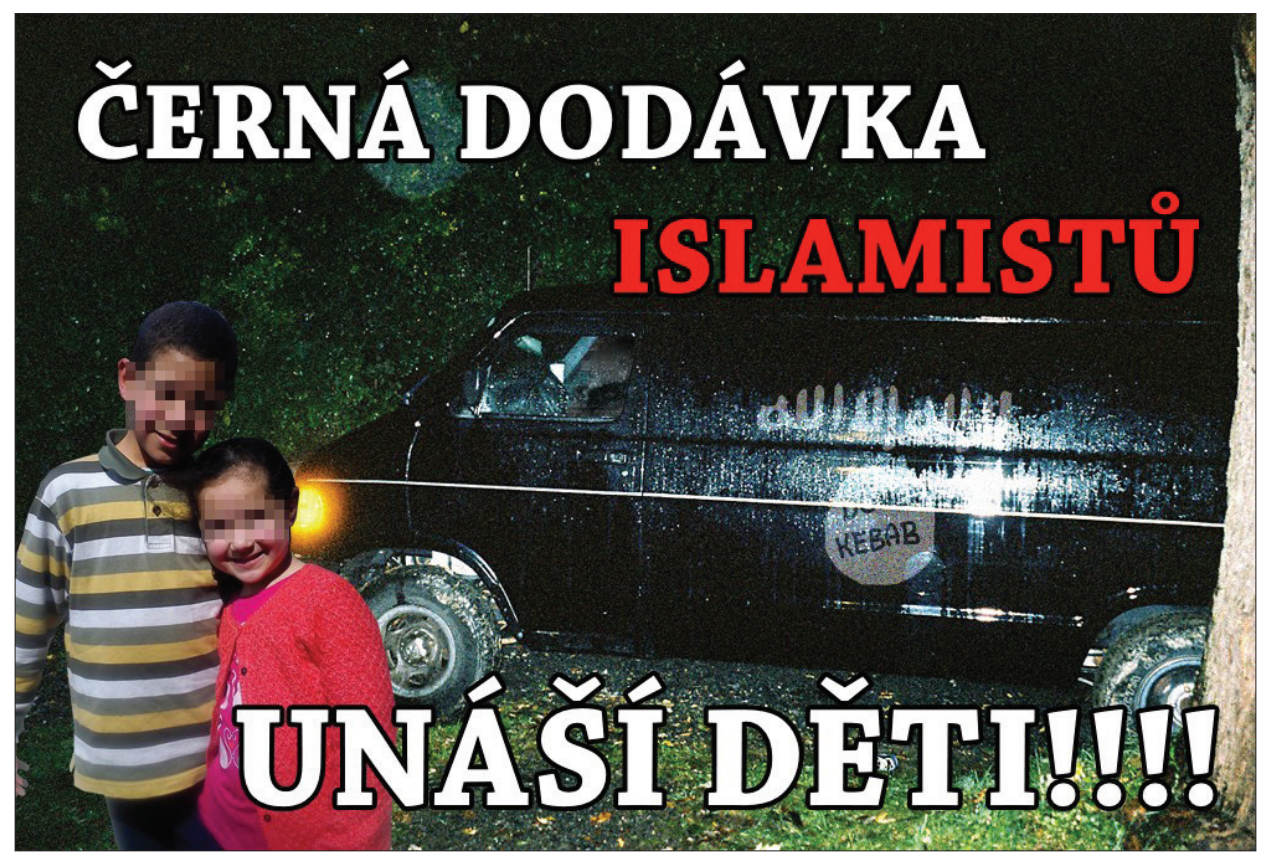

Figure 1. "Islamists' black van is kidnapping children!!!" A hoax spread via Facebook in November 2015. 


\section{THE IMAGE OF THE WEST IN SLOVAKIA IN THE HISTORICAL CONTEXT}

Interesting results arose from public opinion polls conducted among the citizens of the Visegrad Four (V4) countries (Slovakia, the Czech Republic, Poland, and Hungary), which were concerned, among other things, with trust towards the USA and the Russian Federation. According to the survey carried out from May to July 2015 (Gyárfášová \& Mesežnikov 2016), Slovak citizens showed the biggest trust towards the Russian Federation and the smallest towards the USA, as compared to the citizens of the neighbouring countries. The authors of the research report interpreted these data as follows:

The low level of trust towards the United States, which sets Slovakia apart from other V4 countries, can be interpreted as a result of a wide range of historical, ideological, socio-cultural and socio-economic factors, which shaped the public opinion in favour of Russia. These factors include attitudes of some representatives of nineteenth-century national intellectual elite (Ludovít Štúr, Svetozár Hurban Vajanský), leftist intellectuals in the inter-war period, and Slovak communists in the period of 1948-1989. (Gyárfášová \& Mesežnikov 2016: 22)

Similar statements describing the anti-Western attitudes in Slovakia towards the nineteenth-century political sentiments can be found on the Slovak Internet websites in the statements of the Slovak nationalistic ultra-right-wing movements, as well as in the political comments in Slovak dailies. On April 22, 2016, a Slovak daily DenníkN published a blog written by Michal Bábik, who raised the following question:

The blood conflict in Ukraine divides not only Ukraine, but also many of us - in the media, in blogs or social networks. Ukraine literally polarises us: Are we the West or the East, NATO or Russia, whisky or vodka? Where do we belong? It is not for the first time at all that we are raising this question - two hundred years ago, it was raised by our 'founding fathers'national revivalists. (Bábik 2016)

Let us look, for example, at the images of the West in the first half of the nineteenth century, when the Slovak nationalist worldview was being established. The most prominent personality of the Slovak national movement was Ludovít Štúr (1815-1856), professor and deputy of the Hungarian Parliament, who died 150 years ago. In his work Slavdom and the World of the Future, which is (somewhat exaggeratedly) considered his political testament, he depicted his political visions in the manner that became determining for the next generations 
of Slovak nationalists, whose basic ideological scheme was based on emphasising the opposition between the East and the West. The West was described by Štúr as follows:

As noted above, the West is willing to be free on all sides and exercise the principle of freedom which was regained or which arose from historic developments; it wants to be independent from the absolute power of the church, the state, etc., but what do these efforts look like?... The emancipated West... is running away from churches just like prisoners released from prison, rushes into all kinds of pleasures, and everyone fully enjoys the pleasures as if they wanted to compensate for their self-denial, previously enforced by religion...

Fun and pleasure are common words of the day; any means is good to achieve them; and then we see those horrific crime processes in France, trying people for the most barbaric devilries, the most condemnable crimes, such as poisoning, malicious murders because of marital issues, etc. There are devilries and immorality also elsewhere, but these are rather exceptions from the rule, seeking to hide in the darkness; however, in the West, such cases occur in broad daylight, and are even claimed to be right, seeking to be recognised by law, and many even show their pride in them....

Slavery is present also in the United States, and we know with what cruelty English and French colonialists treat their slaves, yet this paganism is equally condemnable, and humanity is raising its voice against it more urgently every time...

There is no peace and stability, everything is being moved and rushed forward, and all see their final, much-sought-for happiness-in perdition! One revolution will follow another, and each time the Western nations will be in a worse situation than before...

Where to turn our sight, from where to draw hope, if the heart that flamed up with love for humans vainly seeks help in the West? Over there, in the far East, because this is where the Slavic nation, the nation of the future lives!... Russians are the only ones among Slavs who preserved their independence and thus saved the reputation of the Slavic name... The only Slavs that feel hostility towards Russians and would act against them if they had the opportunity are the Polish. The Czechs have not shown very brotherly feelings towards Russia recently, which is regretful, indeed, and their books have even been filled with hatred. (Štúr 1993 [1853]: 67, $71,76,114)$

Just like in other countries, it was popular also among the members of intellectual elites in Bohemia and Hungary in the nineteenth century to pursue 
an authentic way of life, not affected by any modern Western influences. The seeking of authenticity in the framework of the romantic image of morally and culturally 'unspoiled' Slovakia as opposed to Bohemia marked by modernisation was part of the rhetoric of the Czech-Slovak cultural cooperation at the turn of the twentieth century. Hereby I would like to offer as an example a reflection by Alois Kolísek, a Czech Catholic priest and supporter of independent Czechoslovakia, written in $1918:{ }^{15}$

The fact that the nature of our nation is in its purity, free of foreign influences (i.e. influence of the Western culture - Z. G.) and basically the same as, for example, in Hungary, is proven by the moral attributes of our people... Not only our language and phraseology are eager to find pure sources of fresh revival. Our spiritual culture also requires it. Not having Slovakia today or tomorrow will be the same as petrifying the Czech spiritual crisis... (cited in Galiová 2003: 114)

Another example is a letter by a Czech intellectual, Marie Smolková, dedicated to Slovak folk art:

There are concerns that the flow of the era penetrating from the West, which has already destroyed so many original things here in Bohemia, dragged us into oblivion and also affected Moravia, extends its harmful effects to Slovakia in Hungary. (Smolková 1896: 50)

At the political level, the period of the Slovak State (1939-1945) and its authoritarian leadership regime following the example of Mussolini's Italy is characterised by the victory of Slovak nationalism and conservatism over the liberal-oriented inter-war Czechoslovak Republic (1918-1939). The official press supervised by the Propaganda Office brought topics of Freemasonry and Jewish and Jewish-Bolshevik conspiracies in the public discourse about the enemy of the nation and Christianity along the lines of German Nazism. The image of the West as morally rotten and leading to a moral disintegration of society, a warmonger allied with Jewish conspirators, is also typical of the rhetoric of Slovak nationalism during World War II. The images of an American and an Englishman, dominated by the features of a rich, greedy businessman, considerably overlap. There is a similar feel of resentment towards the financially successful 'other', just like with the image of a Jew. The moral rectitude of Americans is also discredited by the arms trade (Fig. 2); in the case of a Brit (or an Englishman) it is the attribute of a coloniser who has no moral right to pretend to be a human rights defender (Fig. 3). 


\section{Sviečku páli Bohu i čertovi.}

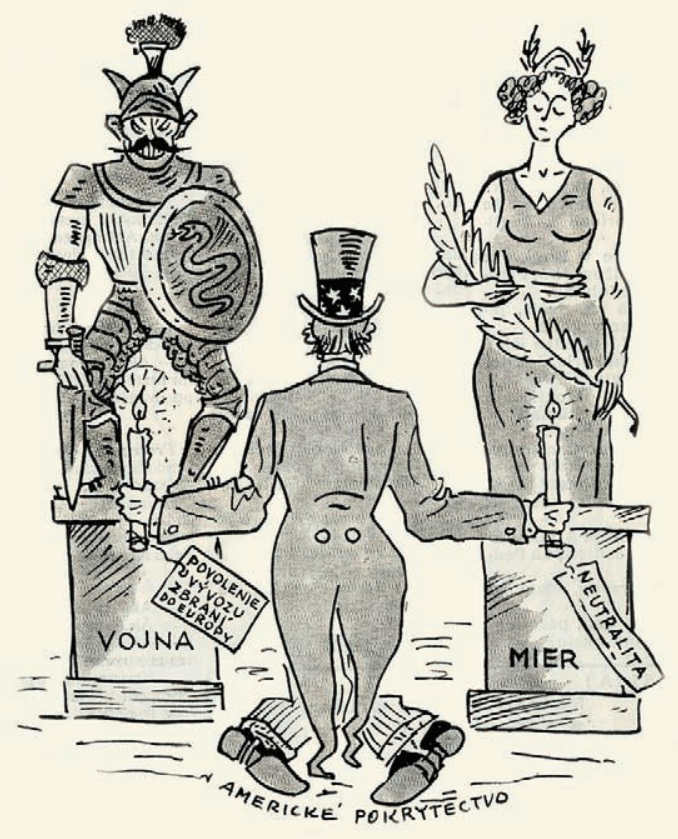

Figure 2. He is burning the candle both to God and the devil. (Kocúr, No. 9, 1939, p. 72)
Figure 3. A world ruler: "The existence and power of England depends on the balance." (Kocúr, No. 14, 1941, p. 168)

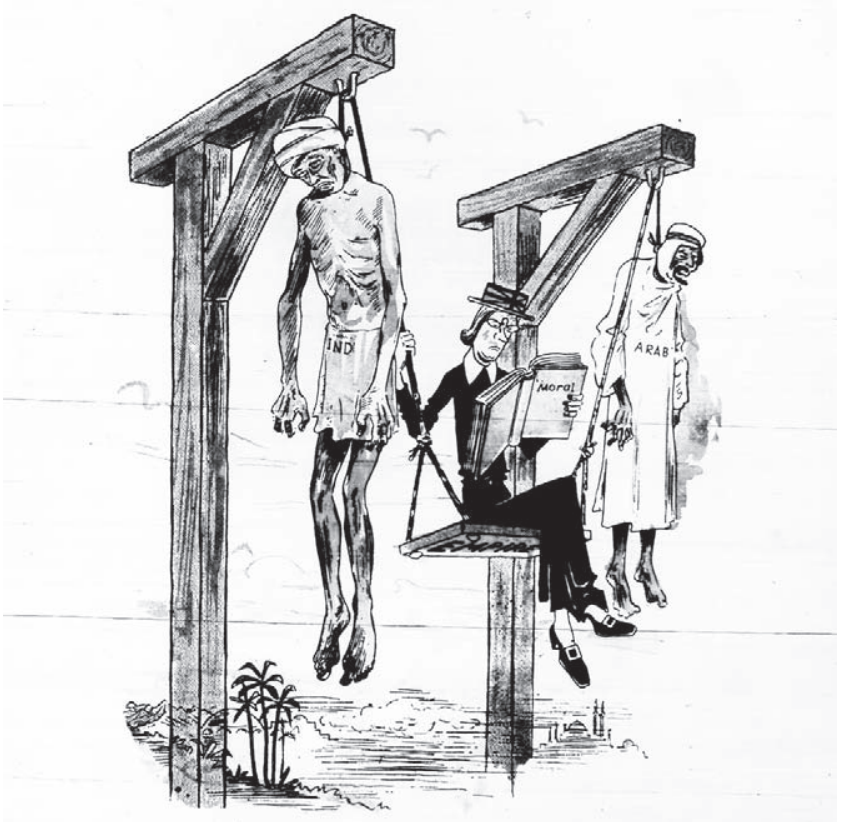

Svetovládca: „Existencia a moc Anglicka závisí od rovnováhy.“ 
In the non-Communist press published in the period immediately after the end of World War II and before the communist coup (from May 1945 to February 1948) we can rather observe neutral or positive images of the West, stressing its technological development. Especially in the case of the USA, we can read travel information bringing exciting stories about their achievements. (This fascination is probably reflected in a variant of the motif of the 'eaten-up granny'. The stories are about a family living in Czechoslovakia right after the end of World War II, receiving a strange mail - a tin filled with dust and bones, sent, according to the postwoman, by the humanitarian organisation of the United Nations Relief and Rehabilitation Administration (UNRRA) ${ }^{16}$. Thinking that it is a kind of a modern western way of instant food treatment, the family adds the tin content to the cabbage soup and eats it - though with disgust. A couple of days later the family receives a shocking message - a delayed telegram about the death of their American granny who wished to be buried in her home country. Hence, the mail was not about 'UNRRA', but 'urna' (Slovak expression for an urn, a vase for holding the ashes of the cremated dead) (Panczová 2013: 144-145).

The victory of the Communist Party in Czechoslovakia in February 1948 was accompanied by the establishment of a totalitarian regime and gradual consolidation of the ideological image of the West. In the next years, this image became the object of accusations of efforts to start a new global world conflict.

The first opportunity of the kind was the conspiratorial interpretation of the Marshall Plan, disseminated in the Czechoslovak press after 1948. Examples of this include newspaper articles such as "Dollar Bringing the West Together. Marshall Plan Approved. Potsdam Agreement Degraded”, which states:

The events, as they fit together, make it clear to every thinking person that it is about turning aside Western European countries, supported by millions of dollars against the Soviet Union as the biggest stronghold of eastern democracies... It is no exaggeration to think that these are the signs of a new war, a new global fire. (Týždeň 1948: 1)

In the official discourse, it is the USA, i.e., America, which became the absolutisation of the West in the political and moral sense. The image of America serves as the essence and source of everything, representing the opposite between the West and the East. In the 1950s, the press started to publish a deluge of articles and caricatures in which the image of the West (including America) was associated with attributes of violence, debauchery (prostitution, frequent change of life partners), lack of progress (superstitions), warmongering warmongers compared to the Nazi (Fig. 4), and social injustice (racism - the image of the $\mathrm{Ku}-\mathrm{Kl}$ lux-Klan, differences in property, unemployment, hunger). The personified 


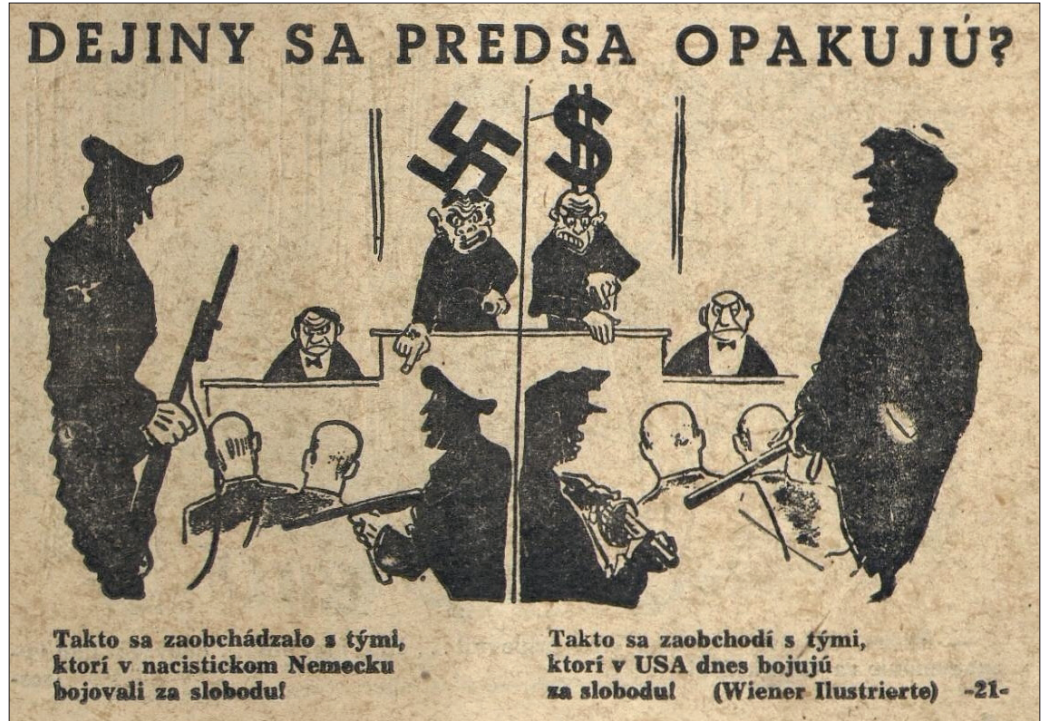

Figure 4. History still repeats itself. (Roháč, Vol. 3, No. 12, 1950, pp. 2-3)

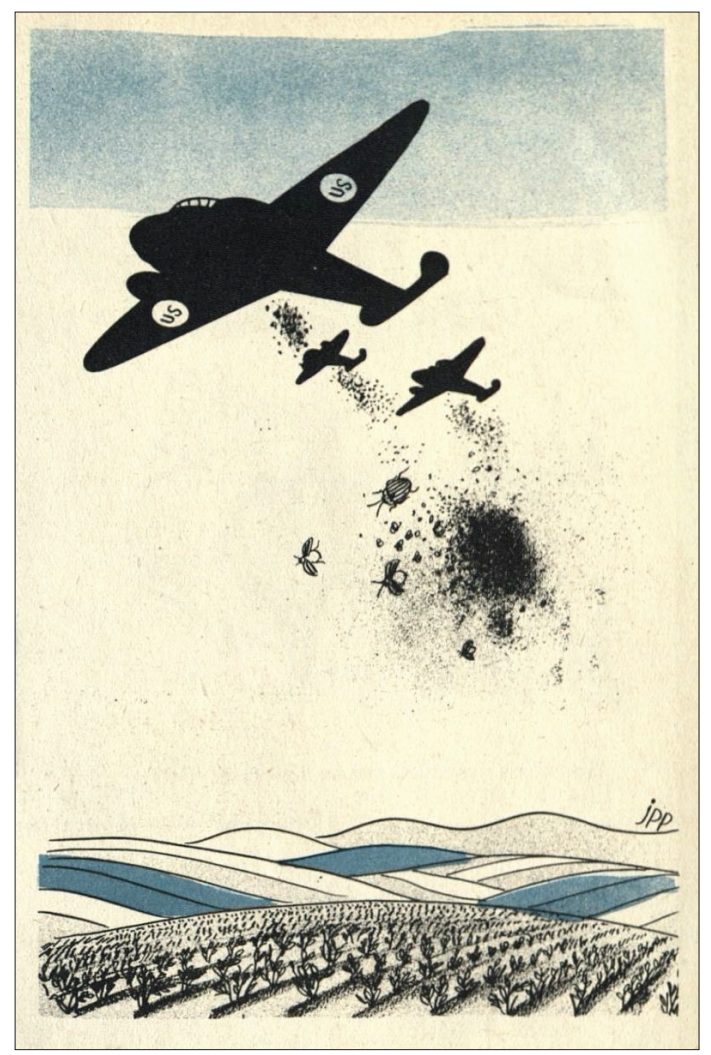

Figure 5. 'Western imperialists' intentionally dropping 'American bugs' (potato beetles) onto the fields of Central Europe, causing a plague. (Roháč, Vol. 3, No. 25, 
West was represented by comic figures of politicians - Churchill as an alcoholic, Eisenhower as a Nazi, and Truman or Acheson as warmongers.

This propaganda was nurtured by occasionally spreading conspiracy theories, such as reports about the use of a biological weapon - potato bugs (Fig. 5) - or support of conspiracy versions of the background of Kennedy's murder. The Czechoslovak press sought to use conspiracy theories concerning J. F. Kennedy's death in 1963 for its propaganda purposes. In its reaction to this event, the press jointly emphasised the "unhealthy violent atmosphere of the American society" with its deep-rooted "self-conceit and superiority", and hinted at the actual offenders from among ultra-right wing organisations and other political opponents of Kennedy's politics, stressing the role of the police and the FBI in concealing evidence:

Overall, there is no doubt that the same forces that have recently led to the actions against black people stand in the background of the assassination... If, however, they manage to present the offender as a madman or if there are even attempts to identify him with Communists, the situation can become very serious, as many observers pointed out... There are even rumours that the whole affair was an attempt of the extreme right to measure the forces, planning to use the heated atmosphere, etc. (Pravda 1963: 1, 3)

The period after 1989 was characterised by euphoria from the regained freedom and big expectations from improved standards of living; on the other hand since the key state institutions and their representatives were not prepared for the changes - we could witness 'wild' privatisation based on stealing the previously national assets, increasing trends of chauvinist nationalism, official emergence of unemployment, homelessness, and the birth of mafia organisations. At the same time, people could easily get into contact with different types of protest movements, radical nationalist and religious subcultures, which were based on conspiratorial ideological schemes and became, together with known stereotypes of national enemies, an inspiration for the conspiracy culture in Slovakia. Shortly after the political change, which ended the forty-year period of the communist totalitarian regime in November 1989, theories revealing the actual background of this event started to be disseminated (for more information see Panczová \& Janeček 2015: 161-162), linking the strings pulled from Washington to the Jewish-freemasonic profile of the main actors (as, for example, president Václav Havel). 


\section{CONCLUSION}

The analysis of the Slovak alternative news websites suggests that their resistance against the existing system is almost always linked to the negative image of the West. There are several reasons why this type of news is so successful in Slovakia at present. One of the undoubted factors is that they use the images and ethnic stereotypes that have been verified and refined through handing down from generation to generation, and used by the propaganda of different political regimes and, in addition, supported by the authority of important personalities in the Slovak national history. This article has shown that the attributes of the West, as spread by conspiracy theories in Slovakia, have been handed down for a minimum of 150 years. The stereotypical images of the USA and the West as societies full of violence, corruption, scandals, deep social inequalities, and moral and cultural decadence represent, even today, a valid principle, according to which the USA and the West act in the role of the enemies of the nation against the Messianic images of the East. The dynamics of the dissemination of conspiracy theories within the Slovak internet space today is characterised by the creation of two considerable rivalling platforms linked to different news categories (pro-Western mainstream vs. pro-Eastern alternative sources) and their mutual discursive interaction. The attitudes towards the West (or the East - which is, however, a less frequent topic) are among the main indicators of affiliation to the respective ideological platform in this rivalry.

Certainly, this paper presents this topic in a very simplified way, since the dissemination of conspiracy theories is influenced by many factors. Awareness about the historical specificities of the context in which conspiratorial attitudes towards the West have been spread in Slovakia forms the basis for the planned European-wide comparative research on this topic.

\section{ACKNOWLEDGEMENTS}

This article was supported by the grant project VEGA 2/0126/14, "Continuity and discontinuity in ethnological research regarding intangible cultural heritage".

\section{NOTES}

1 The historic forms of conspiracy theories and political rumours were studied, for example, by Ploux 2003 (according to Campion-Vincent 2005: 108); Zukier 1987; Poliakov 1987; Groh 1987a, 1987b; etc. 
2 The rivalry between mainstream and alternative in Slovakia has also acquired a form of producing lists of websites, articles or persons that seek to uncover, condemn publicly, and show the links between seemingly independent information sources from the 'other side' (see, for example, www.konspiratori.sk, http://www.poznanie.estranky.sk/ clanky/kto-za-koho-kope-cast-2.html, and http://prop.wz.cz/kto_za_koho.htm, all last accessed on June 16, 2017).

3 In the context of the Nazi propaganda, these were the domestic Jews, members or supporters of opposition parties, as well as 'white Jews', i.e., those members of the 'white'/Us' category, who were, for various reasons, convicted of sharing the Jewish identity (Panczová 2015: 249).

${ }^{4}$ See https://www.sme.sk, https://dennikn.sk/, both last accessed on June 16, 2017.

5 See http://dennikpolitika.sk/, http://zemavek.sk/, http://www.hlavnespravy.sk/, all last accessed on June 16, 2017.

6 The average annual circulation of this monthly magazine in 2015 was 25,000 copies; according to the chief editor, they have around 7,000 subscribers. Source: public debate Havranovo talk show (May 27, 2015); guests: Tibor Eliot Rostas and Juraj Smatana (record of the debate is accessible at https://www.youtube.com/watch?v=ONr6uHADhM, last accessed on June 16, 2017).

7 For example, Slovakian LifeNews (www.lifenews.sk, last accessed on June 16, 2017), medium of the conservative Institute of Leo XIII, inspired by the encyclical of this pope, Humanum Genus, against freemasonry.

Politically active is the Magnificat Slovakia - a citizens' association, publishing house, and since 2012 also a political party, originally aimed to disseminate messages from the alleged apparitions of Virgin Mary. Its webpage mainly publishes translations of articles from foreign alternative sources in the sections "Freemasonry" and "World governance", jointly included in the New Age category. The titles of the articles are, for example: "The essence of the totalitarian European Union", "Slovaks fight for Slovakia against Americans!", "President Kiska (crony of the US and their lies - comment) arrived in Kiev to attend the Pride" (see http://www.magnificat.sk/, last accessed on June 16, 2017).

8 See http://buchanan.org/blog/whose-side-god-now-6337, last accessed on June 16, 2017.

9 The questions about ideological links between these worldviews would be subject for a deeper analysis as it is a complex phenomenon deserving further study.

${ }^{10}$ See http://www.magnificat.sk/aktualne-vyzva-pre-slovensko/, last accessed on June 16, 2017. A similar spirit can be observed in the article by a Russian reporter Darya Aslamova in Komsomolskaya Pravda (August 25, 2015, see http://best.kp.ru/msk/ europe_migrants/, last accessed on June 16, 2017), the translation of which was shared by dozens of alternative websites in Slovakia and the Czech Republic.

${ }^{11}$ See Denník politika, September 15, 2015. Available at http://dennikpolitika.sk/voviedni-sa-siri-zapadonilska-horucka/, last accessed on June 16, 2017.

${ }^{12}$ For example, in US anti-immigration discourse Mexicans and Mexican Americans were sometimes depicted as 'bioweapons'. This term was used also in connection with 
the threat of the swine flu pandemic in 2009, which was interpreted as an artificial bioweapon manufactured by Islamic terrorist (Fine \& Ellis 2010: 75). There are many similar examples from other cultures, after all; we could mention the nineteenth and twentieth century anti-Semitic likening of Jews to cancer, insects or parasites (see, for example, Slovenský obrázkový antisemitský kalendár na rok 1886 (Slovak AntiSemitic Picture Almanac for 1886), pp. 18, 36, 44).

${ }^{13}$ For example, the story about a little boy allegedly assaulted by refugees in the asylum camp in Gabčíkovo (spread via Facebook in 2015; a dementi was published on http:// www.topky.sk/cl/10/1513359/Na-webe-sa-siri-obludne-klamstvo--Emotivny-pribehmatky--ktorej-utecenci-dobili-syna-v-Gabcikove, last accessed on June 16, 2017).

${ }^{14}$ See https://www.facebook.com/STOPxenofobii/posts/895415927172227, last accessed on July 11, 2017.

${ }^{15}$ In Slováci do státu československého (Slovaks to the State of Czechoslovakia).

16 The purpose and functions of the UNRRA were "to plan, coordinate, administer or arrange for the administration of measures for the relief of victims of war in any area under the control of any of the United Nations through the provision of food, fuel, clothing, shelter and other basic necessities, medical and other essential services" (see http://www.ibiblio.org/pha/policy/1943/431109a.html, last accessed on June 19, 2017).

\section{BIBLIOGRAPHY}

Humour magazine Kocúr (1919-1945)

Magazine Týždeň: prehl'ad svetových, hospodárskych a kultúrnych časovostí (1946-1951) Humour magazine Roháč (1948-1991)

Magazine Zem a Vek (2013-)

Daily Pravda (1944-1989)

\section{REFERENCES}

Bábik, Michal 2016. Ukrajinský konflikt z pohl'adu našich otcov zakladatel’ov. [Ukrainian Conflict from the Perspective of Our Founding Fathers.] DennikN, April 22. Available at https://dennikn.sk/blog/ukrajinsky-konflikt-z-pohladu-nasich-otcovzakladatelov/, last accessed on June 19, 2017.

Barkun, Michael 2013. A Culture of Conspiracy: Apocalyptic Visions in Contemporary America. Comparative Studies in Religion and Society 15. Berkeley \& Los Angeles \& London: University of California Press.

Campion-Vincent, Véronique 2005. From Evil Others to Evil Elites: A Dominant Pattern in Conspiracy Theories Today. In: Gary Alan Fine \& Véronique Campion-Vincent \& Chip Heath (eds.) Rumor Mills: The Social Impact of Rumor and Legend. New Brunswick, N.J. \& London: Aldine Transaction, pp. 103-122. 
Crocker, Jennifer \& Luhtanen, Riia \& Broadnax, Stephanie \& Blaine, Bruse Evan 1999. Belief in U.S. Government Conspiracies against Blacks among Black and White College Students: Powerlessness or System Blame? Personality and Social Psychology Bulletin, Vol. 25, No. 8, pp. 941-953. https://doi.org/10.1177/01461672992511003.

Fabick, Stephen D. 2007. Two Psychologically Based Conflict Resolution Programs: Enemy Images and US \& THEM. Journal for Social Action in Counseling and Psychology, Vol. 1, No. 2, pp. 72-81.

Fine, Gary A. \& Ellis, Bill 2010. The Global Grapevine: Why Rumors of Terrorism, Immigration, and Trade Matter. New York: Oxford University Press.

Galiová, Zuzana 2003. Alois Kolísek - kňaz, politik a propagátor slovenskej kultúry. [Alois Kolísek - A Priest, Politician, and Propagator of the Slovak Culture.] Ethnologia Slovaca et Slavica, Vols. 30-31 (1998-1999), pp. 113-128. Available at http://alis.uniba.sk/storage/uk/fif/acta/ID_354_146501.pdf, last accessed on July 12, 2017.

Groh, Dieter 1987a. The Temptation of Conspiracy Theory, or: Why Do Bad Things Happen to Good People? Part I: Preliminary Draft of a Theory of Conspiracy Theories. In: Carl F. Graumann \& Serge Moscovici (eds.) Changing Conceptions of Conspiracy. New York \& Berlin \& Heidelberg \& London \& Paris \& Tokyo: Springer Verlag, pp. 1-14.

Groh, Dieter 1987b. The Temptation of Conspiracy Theory, or: Why Do Bad Things Happen to Good People? Part II: Case Studies. In: Carl F. Graumann \& Serge Moscovici (eds.) Changing Conceptions of Conspiracy. New York \& Berlin \& Heidelberg \& London \& Paris \& Tokyo: Springer-Verlag, pp. 15-38. Available at https://archive.org/details/CarlF.GraumannSergeMoscovicieds. ChangingConceptionsOfConspiracySpringerVerlagNewYork1987, last accessed on June 16, 2017.

Gyárfášová, Ol'ga \& Mesežnikov, Grigorij 2016. 25 Years of the V4 as Seen by the Public. Bratislava: Institute for Public Affairs. Available at http://www.ivo.sk/buxus/ docs//publikacie/subory/25_Years_of_the_V4_as_Seen_by_the_Public.pdf, last accessed on June 19, 2017.

Knight, Peter 2002. Introduction: A Nation of Conspiracy Theorists. In: Peter Knight (ed.) Conspiracy Nation: The Politics of Paranoia in Postwar America. New York \& London: New York University Press, pp. 1-17.

Krekó, Péter \& Gyốri, Lóránt \& Milo, Daniel \& Marušiak, Juraj \& Széky, János \& Lencsés, Anita 2015. Marching Towards Eurasia: The Kremlin Connections of the Slovak Far-Right. Political Capital Kft. and Social Development Institute Kft. Available at https://www.academia.edu/19730490/Marching_towards_Eurasia._The_Kremlin_ connections_of_the_Slovak_far-right, last accessed on June 16, 2017.

Panczová, Zuzana 2013. Humor a strach v poetike súčasných povestí. [Humour and Fear in the Poetics of Contemporary Legends.] Slovenský národopis / Slovak Ethnology, Vol. 61, No. 2, pp. 142-154. Available at http://www.uet.sav.sk/files/ etno2-2013-text-web.pdf, last accessed on June 19, 2017.

Panczová, Zuzana 2015. Images of the Traitor and Enemy in Humour and Political Cartoons in War-Time Slovakia: Analysis of the Magazine Kocúr. In: Dagnoslaw Demski \& Liisi Laineste \& Kamila Baraniecka-Olszewska (eds.) War Matters: Constructing Images of the Other (1930s to 1950s). Budapest: Instytut Archaeologii i Etnologii PAN \& Estonian Literary Museum, pp. 244-273. 
Panczová, Zuzana \& Janeček, Petr 2015. Théories du complote et rumeurs en Slovaque et en Tchéque. Diogène: Les théories du complot aujourd'hui, Vols. 249-250, pp. 150-167. Paris: UNESCO-IULM-Presses Universitaires de France.

Perný, Lukáš 2016. Vládne nám tieňový establišment? [Are We Controlled by Shadow Establishment?] Zem a vek, March 9. Available at http://zemavek.sk/articles/view/ vladne-nam-tienovy-establisment, last accessed on June 16, 2017.

Ploux, François 2003. De bouche à oreille: Naissance et propagation des rumeurs dans la France du XIXe siècle. Paris: Aubier.

Poliakov, Léon 1987. The Topic of the Jewish Conspiracy in Russia (1905-1920), and the International Consequences. In: Carl F. Graumann \& Serge Moscovici (eds.) Changing Conceptions of Conspiracy. New York \& Berlin \& Heidelberg \& London \& Paris \& Tokyo: Springer-Verlag, pp. 105-113. Available at https://archive.org/details/CarlF.GraumannSergeMoscovicieds. ChangingConceptionsOfConspiracySpringerVerlagNewYork1987, last accessed on June 19, 2017.

Pravda 1963 = Svet oceňuje politiku prezidenta Kennedyho. [World Appreciates the Politics of President Kennedy.] Pravda, November 24, pp. 1, 3.

Rieber, Robert W. \& Kelly, Robert J. 1991. Substance and Shadow: Images of the Enemy. In: Robert W. Rieber (ed.) The Psychology of War and Peace: The Image of the Enemy. New York: Plenum Press, pp. 3-38.

Slovenský obrázkový antisemitský kalendár na rok 1886. [Slovak Anti-Semitic Picture Almanac for 1886.] Budapest: Tiskom Imra Bartalitsa.

Smolková, Marie A. 1896. O ženskom domácom priemysle na Uhor. Slovensku. [On Women's Domestic Industry in the Upper Hungary.] Dom a škola, February 1, Vol. 12, No. 2, pp. 48-51.

Šebej, František \& Vašečka, Michal \& Nič, Marián 1998. Pohl'ady predstavitel’ov slovenských politických a spoločenských elít na bezpečnost’ a vstup SR do NATO. (Kauzálne atribúcie v hodnotení nezaradenia Slovenska do prvej skupiny kandidátov na členstvo v NATO.) [The Opinions of Representatives of Slovak Political and Social Elites on Security and Entry into NATO. (Causal Attributions in the Evaluation of Slovakia's Non-Inclusion in the First Group of Candidates for NATO Membership).] In: Martin Bútora \& František Šebej (eds.) Slovensko v šedej zóne? Rozširovanie NATO, zlyhania a perspektívy Slovenska. Bratislava: Inštitút pre verejné otázky, pp. 219-226.

Štúr, Ludovít 1993 [1853]. Slovanstvo a svet budúcnosti. [Slavs and the World of the Future.] Bratislava: Slovak Institute for International Studies.

Týždeň 1948 = Dolár stmeluje Západ. Marshallov plán odhlasovaný. Postupimská dohoda znevážená. [Dollar Bringing the West Together. Marshall Plan Approved. Potsdam Agreement Degraded.] Týždeň, March 20, p. 1.

Zukier, Henri 1987. The Conspiratorial Imperative: Medieval Jewry in Western Europe. In: Carl F. Graumann and Serge Moscovici (eds.) Changing Conceptions of Conspiracy. New York \& Berlin \& Heidelberg \& London \& Paris \& Tokyo: Springer-Verlag, pp. 87103. Available at https://archive.org/details/CarlF.GraumannSergeMoscovicieds. ChangingConceptionsOfConspiracySpringerVerlagNewYork1987, last accessed on June 16, 2017. 


\title{
THE BEAST COMPUTER IN BRUSSELS: RELIGION, CONSPIRACY THEORIES, AND CONTEMPORARY LEGENDS IN POST-SOVIET CULTURE
}

\author{
Alexander Panchenko \\ Center for Anthropology of Religion, European University at St. Petersburg \\ Institute of Russian Literature, Russian Academy of Sciences \\ St. Petersburg State University, Russia \\ e-mail: apanchenko2008@gmail.com
}

\begin{abstract}
Conspiracy theory is a powerful explanatory model or a way of thinking, which influences many cultural forms and social processes across the contemporary world. Recent academic research into conspiracy theories provides a set of interpretations ranging from medicalization (social/political paranoids) to the concept of 'popular knowledge' as a specifically postmodern phenomenon. In modern and postmodern societies, conspiracy theories often motivate political action and social praxis, accompany the transformation of institutional and informational networks, and provoke moral panic and changes of identity. The paper deals with the role of conspiratorial motifs and themes in the formation and transmission of what is known as contemporary legend. The discussion of empirical data focuses on apocalyptic narratives about 'the Beast of Brussels'. Proceeding from the memetic approach in folklore studies as well as the concept of emotional communities, I try to show how and why present-day conspiracy theories and practices of conspiratorial hermeneutics are inspired by particular combinations of emotional, moral, and epistemological expectations.
\end{abstract}

Keywords: conspiracy theory, contemporary Christian eschatology, contemporary legend, emotional communities, meme theory, post-Soviet culture, the Beast of Brussels

\section{INTRODUCTION}

When we discuss the problem of the meaning of what we call folkloric texts, we can approach the issue from quite different positions and use a variety of explanatory models. It seems to me, however, that present-day debates on the meaning of folklore generally proceed from two general models which I would call semiotic and memetic. The first one, ranging from structuralism to psycho- 
analysis, implies that every text or theme or tale type possesses its own initial or immanent meaning that might be transformed through time and place but can still be investigated by means of proper analytical tools. The second one that proceeds from the concept of memes or cultural replicators, suggested by British zoologist Richard Dawkins in his book The Selfish Gene (1976), looks at texts and all other units of cultural imitation as essentially meaningless and as acquiring their particular meaning(s) depending on communicative context(s). In this perspective, survival or long historical life of folk narratives and other 'mind viruses' is provided by their adaptive potential or fitness, which, in turn, is related to the properties of human cognition, memory, and emotions rather than rationally understandable information. ${ }^{1}$ A very similar approach was recently elaborated by cognitive scientists of religion, who considered "religious concepts and norms and the emotions attached to them" to be "designed to excite the human mind, linger in memory, trigger multiple inferences in the precise way that will get people to hold them true and communicate them" (Boyer 2001: 329).

Roughly speaking, this point of view means that any folklore item engaged or employed by human beings or communities that will to connect or conflict does not in fact express or project attitudes or meanings but rather parasitizes on individual or collective emotions and cognitive devices that assemblage knowledge and power in a given social context. Our task as folklorists then is not to uncover any substantial structures of meaning related to this or that narrative but to understand which cognitive and/or emotional properties provide its adaptability in numerous contexts of social communication.

In this article, I try to demonstrate how this approach can be applied in the study of contemporary narrative culture, more precisely, of one particular group of motives or themes that combine religious eschatology with present-day conspiratorial thinking and easily migrate from one confessional subculture to another. Prior to the discussion of empirical data, I need, however, to look in more detail at how conspiracy theories are related to contemporary legend and why conspiratorial narratives appear to be so influential in present-day religious culture. Conspiracy theory is a powerful explanatory model or way of thinking, which influences many cultural forms and social processes throughout the contemporary world. Generally defined as "the conviction that a secret, omnipotent individual or group covertly controls the political and social order or some part thereof" (Fenster 2008 [1999]: 1), a conspiracy theory includes a number of principal ideas and concepts that make it adaptable for a broad variety of discourses and forms of collective imagination. Proceeding from the necessity to explain and localize evil as a social and moral category, conspiracy theories produce ethical models that oppose 'us' to 'them', 'victims' to 'enemies', 'heroes' to 'anti-heroes'. At the same time, conspiracy theories are extremely 
teleological; they do not leave any room for coincidences and accidents and explain all facts and events as related to intentional and purposeful activities of 'evil actors'. Quite often, conspiracy theories are grounded in the holistic worldview that leads, in turn, to particular hermeneutic style. Reality is always considered to be deceptive; simple, superficial, and obvious explanations must give place to more complicated intellectual procedures aimed at the disclosure of 'concealed truth'. From this perspective, the concept of mystery appears to be the most powerful element of conspiratorial narratives that operate in both preand postindustrial societies. Recent academic research of conspiracy theories provides a set of interpretations ranging from medicalization (social/political paranoids) to the concept of popular knowledge as a specifically postmodern phenomenon (Hofstadter 1965 [1952]; Wood 1982; Pipes 1997; Marcus 1999; Knight 2000; West \& Sanders 2003; Birchall 2006; Pelkmans \& Machold 2011). It is obvious, however, that social, political, and cultural power of conspiratorial narratives should not be underestimated. In modern and postmodern societies, conspiracy theories often motivate political action and social praxis, accompany transformation of institutional and informational networks, provoke moral panics and changes of identities.

One of the first theoretical explanations for a conspiracy theory (understood here as an epistemological model rather than a form of collective imagination) was suggested by Sir Karl Raimund Popper in the mid-1940s. It reads as follows:

In order to make my point clear, I shall briefly describe a theory which is widely held but which assumes what I consider the very opposite of the true aim of the social sciences; I call it the 'conspiracy theory of society'. It is the view that an explanation of a social phenomenon consists in the discovery of the men or groups who are interested in the occurrence of this phenomenon (sometimes it is a hidden interest which has first to be revealed), and who have planned and conspired to bring it about. This view of the aims of the social sciences arises, of course, from the mistaken theory that, whatever happens in society - especially happenings such as war, unemployment, poverty, shortages, which people as a rule dislike - is the result of direct design by some powerful individuals and groups. This theory is widely held; it is older even than historicism (which, as shown by its primitive theistic form, is a derivative of the conspiracy theory). In its modern forms it is, like modern historicism, and a certain modern attitude towards 'natural laws', a typical result of the secularization of a religious superstition. The belief in the Homeric gods whose conspiracies explain the history of the Trojan War is gone. The gods are abandoned. But their place is filled by powerful men or groups - sinister pressure groups 
whose wickedness is responsible for all the evils we suffer from - such as the Learned Elders of Zion, or the monopolists, or the capitalists, or the imperialists. (Popper 1966 [1962]: 94; cf. Popper 1962: 163).

In fact, the reasoning cited was intended to emphasize Popper's own indeterministic view on society and history. On the other hand, mentioning "the secularization of a religious superstition" and the gods who are 'abandoned', definitely refers to the progressionist conception of "disenchanted world" (in Max Weber's (1989) terms) if not historical determinism itself. It seems that presently we could hardly rely on this conception, especially after so many scholarly debates on desecularization as well as post-secular society (see, e.g., Berger 1999; Habermas 2006; Karpov 2010; Gorski et al. 2012). However, the very issue of how religion and conspiracy theory are related to each other (even if we approach both from the most radical constructionist positions) still deserves discussion.

At first glance it seems likely that anthropology of secularism (if not the theory of secularization itself) provides some explanatory perspectives in this context. One could suggest, for instance, that conspiratorial modes of thinking that are specifically characteristic of modernity are at least partly related to those configurations of private and public, pluralism and monism, belief and knowledge, which are in the core of 'classic' secular societies, and the gods after their return discovered that they have to share the world, to enter into alliances, or to be at war with secret powers and evil conspirators.

However, the very history of pre-secular Europe does not support this hypothesis. Generally speaking, the conspiratorial ideas and themes that became widespread in the period of the so called "persecuting society" (i.e., in the eleventh-thirteenth centuries; see Cohn 2005 [1973]; Frankfurter 2006; Moore 2007 [1987]), did not, despite their religious contexts, essentially differ from the conspiracy theories of the age of secularism. Moreover, we could trace back the genealogy of those themes and motives to more archaic types of agrarian societies. It is possible to recall, for example, the famous discussion of Azande witchcraft by Edward Evans-Pritchard. Proceeding from a story about an old granary that has collapsed, Evans-Pritchard (1976: 23) suggests that the very idea of witchcraft allows for explaining why "two chains of causation intersected at a certain time and in a certain place":

The Zande knows that the supports were undermined by termites and that people were sitting beneath the granary in order to escape the heat and glare of the sun. But he knows besides why these two events occurred at a precisely similar moment in time and space. It was due to the action of witchcraft. If there had been no witchcraft people would have been sitting 
under the granary and it would not have fallen on them, or it would have collapsed but the people would not have been sheltering under it at the time. Witchcraft explains the coincidence of these two happenings. (ibid.)

I would also recall here the concept of 'limited good' formulated in the 1960s by American anthropologist George Foster. According to Foster, peasant societies "view their social, economic, and natural universes - their total environment as one in which all of the desired things in life such as land, wealth, health, friendship and love, manliness and honor, respect and status, power and influence, security and safety, exist in finite quantity and are always in short supply". This means that "apparent relative improvement in someone's position with respect to any 'Good' is viewed as a threat to the entire community" (Foster 1965: 296-297), and every serious crisis endangering life, health or wealth of the group members often results in 'scapegoating', i.e., pursuit of individual(s) considered to be responsible for the imbalance of goods. From this perspective, the genealogy of the present-day conspiracy theories can be discussed not only with regard to the intellectual history of European modernity (see, e.g., Wood 1982) but also as related to social explanatory models typical of archaic agrarian societies.

At any rate, mutual relations between the conspiracy theories and religious imagination require further discussions and investigations by social scientists. These investigations could probably start with how evil is recognized and localized by various cultures and in different social or economic contexts. It is symptomatic that certain contemporary social phenomena and ideological tendencies that we usually label as religious demonstrate, so to speak, a specific valency towards conspiratorial explanatory models. Christian eschatology gives plenty of obvious examples in this context, especially in relation to present-day apocalyptic thinking. In his book dealing with apocalyptic visions in contemporary America and symptomatically titled A Culture of Conspiracy, political scientist Michael Barkun remarks:

Belief in conspiracies is central to millennialism in the late twentieth and early twenty-first centuries. That is scarcely surprising - millennialist worldviews have always predisposed their adherents to conspiracy beliefs. Such worldviews may be characterized as Manichaean, in the sense that they cast the world in terms of a struggle between light and darkness, good and evil, and hold that this polarization will persist until the end of history, when evil is finally, definitively defeated. (Barkun 2003: 1)

It seems then that religion in contemporary societies is not substituted by conspiracy theories, as it has been suggested by Popper, but absorbs them or is 
absorbed by them. Not accidentally, many religious subcultures today promote not only conspiracy theories, but also a larger group of parascientific beliefs and practices as well as key themes and motives of urban legends - UFO beliefs, spiritual healing, astrology, alternative history, and so on (see Barkun 2003; Birchall 2006). In his book, Barkun goes further to suggest that we presently deal with "a new and growing form of millennialism", which can be called improvisational:

Unlike earlier forms, which elaborated themes from individual religious or secular traditions, improvisational millennialism is wildly eclectic. Its undisciplined borrowings from unrelated sources allow its proponents to build novel systems of belief. (Barkun 2003: xi)

In terms of the history of religious ideas, this shift of religious thinking can be interpreted as a specifically post-secular condition, in which successful religions might and even should "draw upon science for their metaphors and inspiration" (Bainbridge 1993; Rothstein 2004), thus claiming for their own positions within socially valued systems of knowledge production. However, it is still not clear why these or those types of stigmatized or rejected knowledge, including conspiracy theories, are particularly attractive to religious audiences. What makes conspiratorial narratives and themes so popular and adaptable for various groups of believers throughout contemporary world?

\section{THE BEAST OF BRUSSELS: CONSPIRATORIAL NARRATIVES AND APOCALYPTIC IMAGINATION}

From this perspective, I would like to focus on a particular group of conspiratorial/eschatological themes of popular imagination, which make a certain impact on religious cultures in present-day Russia, Ukraine, and some other post-Soviet states, and at the same time have an interesting and analytically important history. It is necessary then to start with historical observations.

The 1970s witnessed the rise of apocalyptic fears and expectations in the United States. The wave of eschatology was mainly related to ideologies of the so called Christian ultraconservatives or the New Christian Right. Although this last term can be used in various ways (sometimes to point to those religious activists who take part in political life), it generally refers to the New Protestants - evangelical Christians oriented towards religious fundamentalism (i.e. literal interpretation of the Bible) and extremely conservative views on politics and society. The movement of religious conservatives involves an essential part 
of Baptist and Pentecostal congregations in the United States as well as numerous non-denominational evangelical groups. Besides social conservatism and certain anti-liberal views, the ideologies of the New Christian Right proceed from clearly formulated eschatological expectations. The mentioned apocalyptic wave of the 1970s was supported not only by theological writings and public sermons. In fact, it gave rise to particular eschatological genres including prophetic visions of the near future as well as apocalyptic fiction and movies telling about terrible events of the 'end times' (Boyer 1992: 115-290; Shuck 2005). In the last decades, these genres of religious fiction were mainly represented by The Left Behind novels and movies by evangelical writers Tim LaHaye and Jerry Jenkins (the first novel in the series was released in 1995, and its film version in 2001). However, the tradition started at the beginning of the 1970s with, for example, low budget evangelical prophecy films produced by Donald W. Thompson:

His four-part series included A Thief in the Night, A Distant Thunder, Image of the Beast, and The Prodigal Planet. The four films, especially A Thief in the Night, dramatized the End-Times scenario familiar to evangelical audiences and transformed it into a powerful conversion tool. (Shuck 2005: 7)

It is necessary to remark here that the aspects of apocalyptic future of the humankind are discussed by evangelical Christians in more detail than, for example, by Russian Orthodox believers, who never paid too much attention to the literal interpretation of the Bible. Attempts to systematize all the eschatological prophesies found in the Old and especially in the New Testament allowed the New Protestants to create several doctrines that describe the future of the mankind before the end of the world and the Last Judgment with some differences. Without going into details of these debates, I have to mention that the arguments mainly deal with the sequence of events related to the Millennial Kingdom of the righteous (Rev. 20), the Great Tribulation described in the Olive discourse by Jesus Christ (Matthew 24: 3-44; Mark 13: 3-33; Luke 21: 5-36), and the Rapture of the righteous (or the true church) to heaven (Paul's 1st epistle to Thessalonians 4: 14-18). According to the doctrine of Pretribulational (dispensational) Premillennialism, it will be Christ who comes back and performs the Rapture. Then the Great Tribulation will come, and the Millennium will start after it has ended. The doctrine of Posttribulational Premillennialism insists that the sequence of apocalyptic events will start with the Great Tribulation, and only those who survive it with true faith and righteousness will take part in the Millennial Kingdom (Boyer 1992: 80-112; Barkun 2003: 41-45; Shuck 2005: 30-41; Fenster 2008 [1999]: 205-206). 


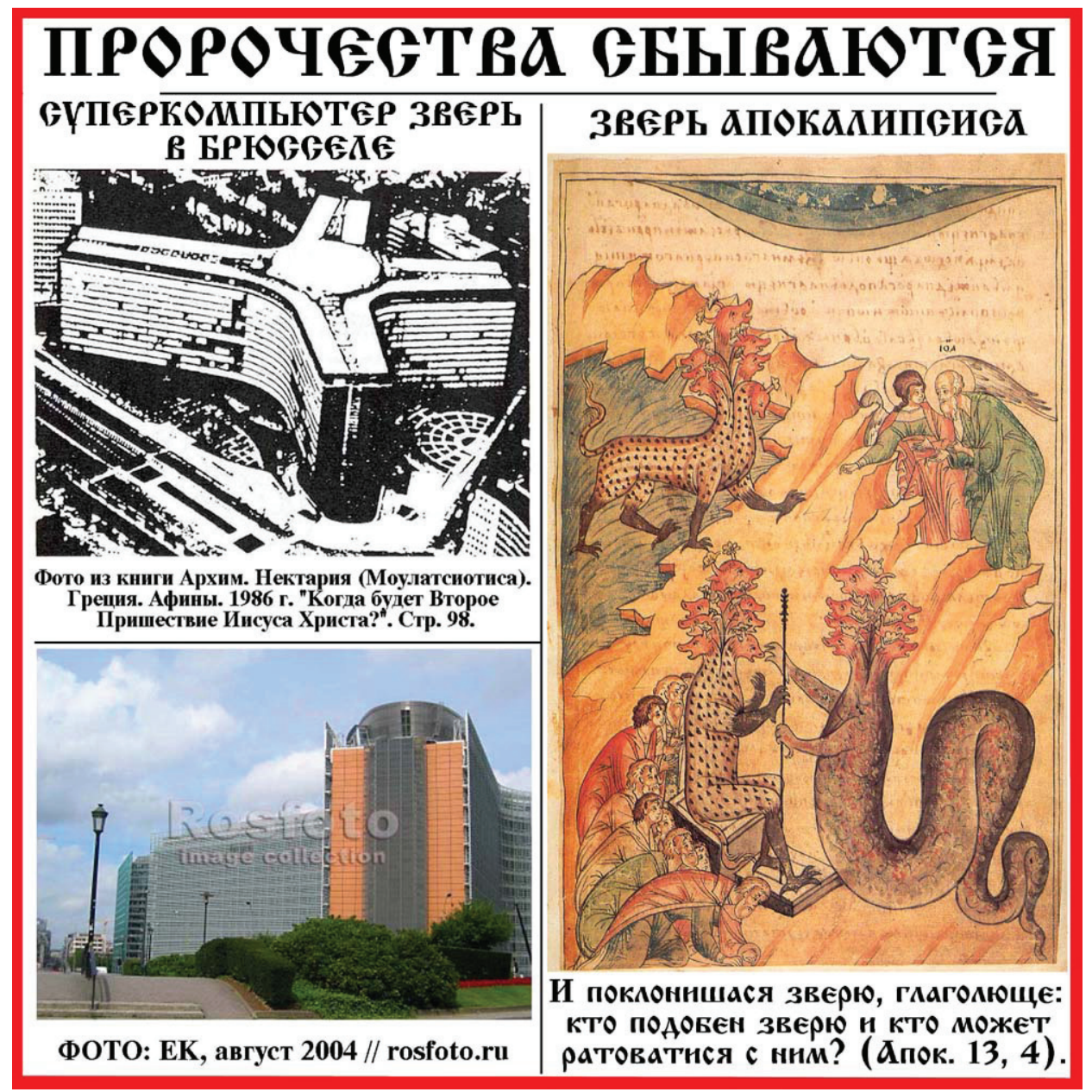

Figure 1. A Russian Orthodox leaflet: "Prophecies are coming true: The Beast supercomputer in Brussels" (http: / / www.zaistinu.ru / articles / ?aid=623).

At any rate, attempts to discover the signs of the Last Times ${ }^{2}$ in the prophetic culture of the New Christian Right did not avoid the discussion of current political events. Special attention in this context was paid to the foundation of the state of Israel in 1948. Although the details of the role to be played by the Jews in the Last Times can be debated by various groups of the fundamentalist Christians, all of them agree that "Israel is being gathered for conversion and redemption" (to use the formulation by conservative Pentecostals in Russia). ${ }^{3}$ 
At the same time, geopolitical scenery of the last decades of the Cold War provided American evangelicals with a spacious field for apocalyptic fantasies about the Antichrist, his allies and forerunners, appearance, activities, and so on. The old Protestant tradition of thinking about the Holy See and Roman Catholicism as somehow related to apocalyptic imagery was now supported by a new political agenda. The movement that started with the Rome agreement of 1957 and led to the foundation of the European Union in 1992 was interpreted by many ultraconservative Christians in the same eschatological context - as preparations for the coming of the Antichrist (Boyer 1992: 273-277). The union of European nations was considered to be the new incarnation of the Roman Empire or even the ten-horned beast from the Revelation (13) and Daniel's vision (7: 23); this was discussed when Greece became the tenth member of the Common Market (Boyer 1992: 277). On the other hand, American Christian fundamentalists were generally suspicious of international political organizations with global authority (the United Nations and others). This particular anti-globalism was one of the leading themes of American apocalyptic narratives of the 1970 s.

Another eschatological theme that was getting more and more powerful was the phobia of certain information technologies: first television that could be used by demonic forces and the Antichrist himself, and later on also computers (Boyer 1992: 106-107, 279-281). Those fears were related to the idea of total control and manipulation of all the human beings from the side of hidden and mysterious forces that use powerful and ubiquitous technical devices. In the 1970 s, this image of the 'surveillance society', to use the term by the Canadian sociologist David Lyon (1994; cf. Shuck 2005: 119-128), was discussed and interpreted with special attention in 1984, the famous dystopian novel by George Orwell. This literary text, although being purely secular, was read by many Christian conservatives in terms of their own apocalyptic prophesies and could be regarded by them as one of the signs of the Last Times coming soon or even as a precise description of the near future of the mankind. It is possible, however, to talk about more general social contexts that bring together the literary genre of dystopia and the conspiratorial eschatology of the twentieth century. According to an astute observation by Maria Akhmetova, apocalyptic narratives that became widespread in Russia in the 1990s and 2000s often depict the future tyranny of the Antichrist "in correspondence with the dystopian novel, a literary genre that was taken by late Soviet and post-Soviet readers as describing totalitarianism of the twentieth century" (Akhmetova 2010: 195). I would say, however, that it is not only totalitarianism (or specific Soviet experience) that influences both dystopian novels and apocalyptic narratives; the very image of the 'surveillance society' could be related to global processes of modernization, 
urbanization, and formation of consumer society. It seems that collective fears associated with anonymity, loss of social status, and control over one's own body are stimulated by those global factors and, in particular, represented by dystopian and apocalyptic narratives.

Fears and expectations of this kind seem to constitute the initial context for the story of the Beast computer that I am talking about. In the late 1970s, Christian prophecy writers in the United States started repeating a rumor "that a giant supercomputer is being created in Brussels for the purpose of taking over the world's banking system and creating a cashless economic system, as was prophesied in Revelation" (Fuller 1995: 181). Its particular sources can be debated, but it seems that the "canonic' version of the story was invented in 1975 by a certain person from the Southwest Radio Church, a non-denominational evangelical radio broadcast program in Oklahoma City. ${ }^{4}$ The most likely authors of the story were pastors David Webber (1931-2004) and Noah Hutchings (1922-2015), who later on published a special book titled Computers and the Beast of Revelation (1986). In 1975, "the Southwest Radio Church reported that this supercomputer, dubbed 'the Beast,' would link banks throughout the world and gradually force 'a socialistic economic leveling and a new money system in the 1980s.' In the same year Colin Deal (a prophecy writer especially known for his bestseller Will Christ Return by 1988? 101 Reason Why) informed his readers that 'Common Market leaders during a crisis meeting in Brussels, Belgium, were introduced to the 'Beast,' a gigantic computer that occupies three floors of the Administration Building at the Common Market Headquarters. The computer is capable of assigning a number to every person on earth in the form of a laser tattoo. Then, through infrared scanners, this invisible tattoo would appear on a screen"' (Fuller 1995: 181).

It is obvious that the rumor, on the one hand, proceeded from the images and ideas of Revelation 13, and, on the other, hinted at the commercial use of barcoding that in the mid-1970s was getting popular in the United States and later in Europe (the first item with a barcode was a pack of Juicy Fruit chewing gum sold in Ohio on June 26, 1974). Quite soon, the story about the Beast of Brussels became popular enough in the United States without any references to particular Christian authors. Its main version that can still be found on the web reads as follows:

Dr. Hanrick Eldeman, Chief Analyst of the Common Market Confederacy in Brussels, has revealed that a computerized restoration plan is already under way to straighten out world chaos. A crisis meeting in early 1974 brought together Common Market leaders, advisers and scientists at which time Dr. Eldeman unveiled "the Beast". The Beast is a gigantic three story computer located in the administrative building of the headquarters of 
the Common Market. That monster is a self-programming computer that has more than one hundred sources distributing entries. Experts in programming have perfected a plan that will handle by computer all of the world's trade. This master plan would imply a system of digital enumeration of each human being of the earth. Thus the computer would give each inhabitant of the world a number to be used for each purchase or sale, removing the problem of present credit cards. This number would be invisibly tattooed by laser, either on the forehead or on the back of the hand. This would establish a walking credit card system. And the number could be seen only through infrared scanners, installed in special verification counters or in business places. Dr. Eldeman pointed out that by using three entries of six digits each, every inhabitant of the world would be given a distinct credit card number. ${ }^{5}$

In the $1980 \mathrm{~s}$, the narrative gained international popularity and was translated into European languages. One of the books that especially promoted the rumor was the bestseller titled When Your Money Fails, by Mary Relfe, a Christian writer from Alabama. However, before discussing the book in more detail, it is necessary to point out the immediate political context of the story about the Beast of Brussels.

The mentioning of a crisis meeting in early 1974 in the narrative was not accidental. The fact is that 1973 witnessed the first (and still the hugest) global oil crisis. Eleven days after the beginning of the Yom Kippur (or October) war between Egypt, Syria, and Israel, the OPEC states announced suspension or shortage of oil supply for the United States and their allies supporting the Jewish state. Soon the oil prices grew four times, from 3 to 12 dollars per barrel. On November 6, 1973, the ministers of foreign affairs of the Common Market met in Brussels and signed a declaration stating that Israel had to implement the 242 resolution of the UN Security Council, i.e., to quit the Sinai Peninsula and the Golan Heights. Finally, those political debates led only to a split in NATO and the maintenance of high oil prices, so the state that benefited was the Soviet Union; the crisis laid the foundation for the 'Brezhnev prosperity'. At the same time, the 1973 war stimulated a new deterioration of relations between the United States and the USSR. When the Israeli army launched a counteroffensive and forced a crossing over the Suez Canal, Brezhnev threatened that the USSR would go into action directly and the United States announced alert of their nuclear forces.

For American evangelicals, the events of the October war directly corresponded with their apocalyptic prophecies and expectations. One of the main themes of the American prophecy narratives of the early 1970s was a future catastrophic war between Israel, Arab states, and the USSR. According to the 
political predictions made by one of the most famous American prophecy writers, Hal Lindsey, in 1970, the following 'players' will dominate the geopolitical scene in the Last Times:

Russia (equivalent to the 'Gog' peoples of Ezekiel), which is developing a vast army and confederacy and will march on Israel; the Arabs, who will join with Africans and be led by Egypt in a march on Israel; China and a vast 'Oriental horde' of more than 200 million soldiers; and the European Community, which will form a new Roman Empire and dominate the world under its leader, the Antichrist. (Fenster 2008 [1999]: 201)

However, Israel was not defeated by Arabs, the world economy did not collapse, the third world war did not start, and the story about the Beast of Brussels started living its own life, acquiring new meanings and contexts. From this perspective, its Russian biography appears to be quite interesting.

The narrative attempted to reach its Russian audience several times. As far as I know, all the Russian translations of the story were related to the book When Your Money Fails: The "666 System" Is Here (1981), by an evangelical writer and founder of the League of Prayer, Mary Stuart Relfe (1916-2011), who lived in Montgomery, Alabama. Proceeding from the idea that the number 666 was penetrating all realms of everyday life in America (the number was found even on sections of floor tiles and shirt labels), Relfe paid special attention to the development of international banking and spread of debit cards that would, she thought, be the principle device of the economic enslaving of the mankind. The story about the Beast computer and Dr. Eldeman was repeated in the book several times (Relfe 1981: 37, 42-46). Moreover, its readers learned that the "little 'Beast of Brussels' was giving way to the real Beast of Luxembourg, the most gigantic Computer Complex in the world, due to completion in 1980" (Relfe 1981: 46). Among other signs of the future reign of the Antichrist, she pointed to the rise of various international organizations, including the World Bank, the World Health Organization, the International Monetary Fund, and others. Some parts of the book focused on the future apocalyptic role of the Soviet Union, which was still believed to be the homeland of the 'Gog' peoples of Ezekiel. To prove that Russia would indeed be the army of horsemen that would come "in the latter years... against the mountains of Israel" (Ezekiel 38: 8), Relfe reprinted in her book a 14-kopek stamp "10 years of the First Cavalry", issued in the USSR at the beginning of 1930. According to Relfe, the stamp picturing armed horsemen with a red banner and the map of the Black Sea region with the cavalry raids marked, "prophetically commemorated" the coming invasion of Russians of Israel (Relfe 1981: 182-183). 
However, all those prophecies did not embarrass one of the first Russian translators of the story about the 'Beast of Brussels', a professor of the Russian language and literature at the University of South Alabama, Pavel Vaulin (1918-2007; see Aleksandrov 2005: 92). Vaulin was a Russian émigré, taken prisoner during the Soviet-Finnish War. After the end of the Second World War, he managed to escape from Finland to Sweden and later on to the United States. There he soon joined the radical religious and nationalistic wing of the Russian diaspora. In 1981, Vaulin translated the introductory part of When Your Money Fails and published it (without references to the original) in his Russian-language journal Niva ([Vaulin] 1981).

Another translation of the same part was prepared independently by either Russian Baptists or Old Believers in America and reached Russia in the late 1980s. A handwritten version of this text was discovered among the manuscripts left behind by an Old Believer from the Urals in 1989 (Ageeva 1997: 11, 16; Soboleva 1997; Pokrovskiy \& Zolnikova 2002). In the same year, the same text was printed in the almanac Put' Spaseniia (The Way of Salvation) published by Russian Old Believers in Oregon ([Tayson V.] 1989). The publication mentioned the author of the translation (a V. Tayson) as well as its sources. The latter included (besides When Your Money Fails) another book by Relfe published in 1982 as well as publications by Australian evangelical missionary Don Stanton (1977) and American Christian writer Willard Cantelon (1973). Yet, it seems that When Your Money Fails was the principal source for the translation. Later on, in 1993, the same text was published by a Russian Baptist publishing house situated in Sochi (Tayson 1993). Although the very name Tayson does not sound Russian, it is possible that the translator was another Russian émigré, Vera Tayson, who in the 1980s was employed as a translator and proofreader by the Russian language newspaper Nashi Dni (Present Days) published by the Pacific Coast Association of Slavic Baptist Churches in Sacramento. ${ }^{6}$ It seems then that this translation had been initially prepared by Russian Baptists in America in the mid-1980s but was also publicized by global networks of the Old Believers.

At any rate, the story about the 'Beast of Brussels' penetrated the borders of the USSR already in the second half of the 1980s. However, the mass spread of the legend in post-Soviet Russia was stimulated not only by the Old Believers' manuscripts and Baptist publications. In September 1991, the head of the publicist department in the journal Nash Sovremennik (Our Contemporary), Sergey Fomin, published a selection of apocalyptic 'prophecies about the destiny of Russia' (Fomin 1991). Later, this selection became part of a huge volume entitled Rossiya pered vtorym prishestviem (Russia before the Second Coming) and edited by Fomin as well. The volume was published repeatedly in Russia in the 1990s and 2000s. Both the 1991 collection and the later separate edi- 
tions included a letter written by monk Antoniy Chernov who at that time lived in the UK and was a member of the 'old calendarist' Genuine Orthodox Church of Greece (Matthewite Synod). The letter (Fomin 1991: 128) included the legend about the 'Beast of Brussels' (quoting the translation by Tayson) and informed its readers about the coming reign of Antichrist, the Jewish pseudoMessiah who had been already born in Israel. This last part of the text was openly anti-Semitic and clearly contradicted pro-Zionistic ideologies of American Evangelical millennialism, so it was obviously borrowed from other (most likely Greek Orthodox) sources. Finally, another independent translation of the story about the Beast computer was printed also in 1991 in the radical monarchist newspaper Zemshchina published in Moscow by the association Khristianskoe Vozrozhdenie (Christian Revival).

It seems that the principal mediators between American evangelical millennialism and post-Soviet high-tech eschatology were Orthodox Greeks. It is quite likely that official religious affiliation of Antoniy Chernov affected the themes of his apocalyptic prophecies. It is worth mentioning that the late 1980s witnessed a moral panic among Orthodox Greeks, the panic being related to the implementation of the Schengen Treaty. The Greek government had signed it in 1992 , but the national parliament ratified it only five years later. The principal 'anti-globalist' argument against the treaty from the side of Orthodox activists was the change of national passports for universal identification cards. The latter in particular were considered to be 'marks of Antichrist'. An additional stimulus for the panic was provided by a public discussion of whether the cards should have indication of the holders' religious affiliation on them (see Molokotos-Liederman 2003). The rumors about the 'Beast of Brussels' related to the panic were promoted not only by small and marginalized 'old calendarist' churches but also, for example, the Greek Orthodox monks from Mount Athos. The book by Relfe, which appeared to be extremely popular at least in some Athos monasteries, was translated into Greek in the mid-1980s (Meletiy 2001: 5-9). In 1987, an Athos monk, Paisios Eznepidis (1924-1994, known also as venerable elder Paisios of the Holy Mountain and canonized in 2015 by the Ecumenical Patriarchate of Constantinople), wrote a pamphlet titled Signs of the Times, 666, which said, in particular:

The secular spirit of contemporary 'freedom', lack of respect to the Church of Christ, to those elders, parents, and teachers who possess the fear of God mask spiritual enslavement, confusion, and anarchy that leads people into a dead end, to spiritual and physical catastrophe. The perfect system of 'convenient cards' and computer security also masks the global dictatorship, the reign of the Antichrist. [...] And all that goes on when the signs are so evident, when the computer 'Beast' in Brussels has nearly 
swallowed up all the countries. Cards, IDs, 'marks' - what do they mean? [...] After the introduction of cards and IDs and 'computer dossiers' they will try to introduce marks. And they will talk on TV how people steal somebody else's cards and get cash. And, on the other hand, they will advertise a 'perfect system'-invisible laser marks in hands and foreheads with 666, the name of the Antichrist. ${ }^{7}$

The popularity of this text and some other writings of this kind by the Athos elders among late Soviet and post-Soviet Orthodox believers seem to account for the 'explosive' transmission of the Russian versions of the story about the Beast of Brussels and Dr. Eldeman at the beginning of the 1990s (see Akhmetova 2010: 146-148). Soon this narrative became a part of the 'conspiratorial canon' shared by radical Orthodox groups protesting against barcodes, individual taxpayer numbers, and electronic cards (see Verkhovskiy 2003: 73-94; Serzhantov 2007-2008; Beglov 2014: 123-126; Russele 2015). Moreover, this very story served as a sort of a narrative foundation or even a trigger for the moral panic that influenced theological and ideological discussions in many religious communities, including the Russian Orthodox Church of the Moscow Patriarchate, the latter having to consider the problem of the individual taxpayer and social security numbers as well as passports with electronic chips at the highest levels of hierarchy (Russele 2015). At the same time, the legend was shared by radical Orthodox groups in Ukraine, Byelorussia, and Kazakhstan, as well as some Pentecostal and Baptist congregations. Here, the fears of computers, barcodes, and individual numbers were largely supported by anti-Western sentiments and ideologies. The Beast of Brussels now was considered to be a part or even the center of apocalyptic conspiracy targeted at Russia (identified here as the former Soviet Union rather than present-day Russian Federation) and the Orthodox belief. Unlike American evangelicals, the post-Soviet supporters of the legend sometimes interpreted it with respect to anti-Semitic beliefs, i.e., as a part of the global Jewish conspiracy.

\section{CONCLUSION}

What conclusions can be drawn from this story? Obviously, it is not unique or absolutely novel in a broad historical context. Themes of count, manipulation of individuals, and total control upon mankind by evil and hostile forces before the end of the world penetrate the history of Christian eschatology. The image of bodily marks inspired by Revelation 13 can be observed in many religious and cultural contexts. American evangelicals and present-day Russian Orthodox 
believers feared laser tattoos inscribed on the body by the Beast of Brussels; Russian nineteenth-century peasants refused vaccination considering it to be 'marks of the Antichrist'.

At the same time, some aspects of the history of the legend about the Beast of Brussels and its intercultural migrations seem to be relatively novel and deserve special attention. Firstly, it brings us back to the memetic approach in the study of contemporary legend. Its international transmission as well as de- or re-contextualization gives one more example of the 'virus' spread of 'cultural replicators' (Oring 2014a, 2014b). This means that we can talk of moral panics inspired by particular conspiratorial narratives as 'cultural epidemics' or "emotional snowballing - runaway selection for emotional content rather than for information" (Heath \& Bell \& Sternberg 2001: 1040). Secondly, this particular text seems to be a part of a broader conspiratorial (meta)narrative, which appeared to be equally valid for quite different religious ideologies and cultures. The same package of eschatology of control and manipulation contains, for example, religious homophobia, the unexpected and at the same time extremely rapid spread of which in present-day Russia could be related to the same American evangelical tradition. Another prophecy writer of the early 1970s, a Pentecostal pastor David Wilkerson (1931-2011), for example, combined in his major work, The Vision (1973), predictions about 'new global economic order' and laser tattoos with the image of future 'moral landslide':

The most gripping images of America as Sodom appeared in the muchreprinted prophecy books of the Assemblies of God evangelist David Wilkerson. In contrast to most prophecy interpreters, Wilkerson in The Vision reported verbatim communications from God foretelling a coming "moral landslide" of "nudity, perversion, and a flood of filth." Television networks will show bare-breasted women; churches will feature nude dancing; "wild, roving mobs of homosexual men" will attack unsuspecting victims openly on the streets. (Boyer 1992: 234)

Nearly the same combinations of eschatological, conspiratorial, and moral expectations can be found in apocalyptic narratives supported and transmitted by various religious groups (whether they were Orthodox, Protestant, or New Age) in post-Soviet states. What factors, however, do shape those narratives as well as their reception or target groups?

It seems to me that the studies of present-day conspiratorial cultures and narratives could take into account the concept of emotional communities formulated recently by American historian Barbara Rosenwein. This constructionist idea that, in turn, proceeds from the theory of textual communities by another American historian, Brian Stock, implies that we should pay more attention to 
emotions that are expected by a particular community and thus are especially valued by its members. "Emotional communities," wrote Rosenwein, "are largely the same as social communities - families, neighborhoods, syndicates, academic institutions, monasteries, factories, platoons, princely courts. But the researcher looking at them seeks above all to uncover systems of feeling, to establish what these communities (and the individuals within them) define and assess as valuable or harmful to them (for it is about such things that people express emotions); the emotions that they value, devalue, or ignore; the nature of the affective bonds between people that they recognize; and the modes of emotional expression that they expect, encourage, tolerate, and deplore" (Rosenwein 2010: 11). I would not argue that the conspiratorial communities that we are dealing with in the present-day world should be recognized as purely emotional. By and large, conspiracy theories try to make problematic not only socially shared values, but also the status of conventional or official knowledge. I think, however, that conspiracy theories and practices of conspiratorial hermeneutics are inspired by particular combinations of emotional, moral, and epistemological expectations. These shared expectations provide the conspiratorial communities with particular narratives and practices and, on the other hand, allow for combining traditional religious ideas with newly invented conspiratorial ones.

In this context, the legend about the Beast of Brussels as well as similar conspiratorial narratives and themes appear to have enough potential to inspire and even form religious communities that expect to share fears of modern technology and surveillance society, tend to distrust science and social institutions, and feel a need of knowledge that can be easily interpreted in moral terms of good and evil. Although some present-day anthropologists would argue that, epistemologically, "there are no inherent differences" between conspiracy theories and other theories (Pelkmans \& Machold 2011), it seems that in terms of social effect and adaptability conspiratorial narratives that constitute a vast part of contemporary legends should still be set apart. In my opinion, their specific fitness potential is related to unique combinations of emotional, moral, and epistemological expectations, which constitute the very idea of conspiracy and secret power in many present-day societies.

\section{ACKNOWLEDGEMENTS}

The research was supported by a grant from the Russian Science Foundation, project No. 14-18-02952 ("Conspiratorial Narratives in Russian Culture"). 


\section{NOTES}

1 For discussion, criticism, and further reading about the meme theory in general see Aunger 2000. See also recent discussion of the memetic approach in folkloristics by Elliot Oring (2014a, 2014b).

2 I would prefer to use 'Last Times' rather than 'Doomsday' to emphasize that premillenial prophetic imagination deals not only with the Last Judgement as a particular event but with sort of 'histories of the future' as a more complicated set of events.

${ }^{3}$ On philo-Semitic and pro-Zionistic aspects of Evangelical millennialism see Ariel 2011.

${ }^{4}$ I would also mention that there is, so to speak, a false trail here - the skeptical narrative about a Christian author, Joe Musser, who is supposed to have invented the story about the 'Beast' computer for his apocalyptic anti-utopian novel. This version, which has received a wide diffusion on the Internet, has been believed by certain researchers (see, e.g., Lewis 2001: 24; Akhmetova 2010: 147), but I have not been able to find any factual evidence to support it.

5 See https://www.truthorfiction.com/beastofbelgium/, last accessed on July 3, 2017.

6 See her name listed among the former staff members on the website of the newspaper: http://www.nashidni.com/index.php/aboutus-en/our-staff/former-and-current-staffmembers. See also her autobiographical article in another newspaper published by Russian Baptists in Germany (Tayson 1980).

7 See http://www.odigitria.by/2012/06/28/znameniya-vremen-666-starec-paisij-svyatogorec/, last accessed on July 3, 2017.

\section{REFERENCES}

Ageeva, Elena 1997. Staroobriadcheskaia polemika ob antikhriste na iskhode XX v. [Disputes about the Antichrist among Old Believers in the Late 20th Century.] Ural'skii sbornik. [The Ural Collection.] Ekaterinburg: n.p., pp. 9-16. Available at http://elar.urfu.ru/bitstream/10995/21345/1/us1997-02.pdf, last accessed on May 12, 2017.

Akhmetova, Maria 2010. Konets sveta v odnoi otdel'no vziatoi strane: religioznye soobshchestva postsovetskoi Rossii $i$ ikh eskhatologicheskii mif. [The Apocalypses in One Particular Country: Religious Communities of Post-Soviet Russia and Their Eschatological Myth.] Moscow: RGGU.

Aleksandrov, Evgeniy 2005. Russkie v Severnoi Amerike: Biograficheskii slovar'. [Russians in North America: A Biographical Dictionary.] St. Petersburg: SPb State University Press.

Ariel, Yaakov 2011. "It's All in the Bible": Evangelical Christians, Biblical Literalism, and Philosemitism in Our Times. In: J. Karp \& A. Sutcliffe (eds.) Philosemitism in History. Cambridge: Cambridge University Press, pp. 257-285.

Aunger, Robert (ed.) 2000. Darwinizing Culture: The Status of Memetics as a Science. Oxford: Oxford University Press. 
Bainbridge, William Sims 1993. New Religions, Science, and Secularization. In: D. G. Bromley \& J. K. Hadden (eds.) Religion and the Social Order: The Handbook on Cults and Sects in America, Vol. 3, Part A. Greenwich, CT \& London: JAI Press Inc., pp. 277-292.

Barkun, Michael 2003. A Culture of Conspiracy: Apocalyptic Visions in Contemporary America. Berkeley \& Los Angeles \& London: University of California Press.

Beglov, Aleksei 2014. Eschatological Expectations in Post-Soviet Russia: Historical Context and Modes of Interpretation. In: K. Tolstaya (ed.) Orthodox Paradoxes: Heterogeneities and Complexities in Contemporary Russian Orthodoxy. Leiden: Brill, pp. 106-133.

Berger, Peter L. (ed.) 1999. The Desecularization of the World: Resurgent Religion and World Politics. Grand Rapids, MI: William B. Eerdmans.

Birchall, Clare 2006. Knowledge Goes Pop: From Conspiracy Theory to Gossip. Oxford \& New York: Berg.

Boyer, Pascal 2001. Religion Explained. The Human Instincts That Fashion Gods, Spirits and Ancestors. New York: Basic Books.

Boyer, Paul 1992. When Time Shall Be No More: Prophecy Belief in Modern American Culture. Cambridge, Mass.: Belknap Press.

Cantelon, Willard 1973. The Day the Dollar Dies. Plainfield, NJ: Logos International.

Cohn, Norman 2005 [1973]. Europe's Inner Demons: The Demonization of Christians in Medieval Christendom. London: Pimlico.

Evans-Pritchard, Edward 1976. Witchcraft, Oracles, and Magic among the Azande. Oxford: Oxford University Press.

Fenster, Mark 2008 [1999]. Conspiracy Theories: Secrecy and Power in American Culture. Revised and Updated Edition. Minneapolis \& London: University of Minnesota Press.

Foster, George M. 1965. Peasant Society and the Image of Limited Good. American Anthropologist, Vol. 67, No. 2, pp. 293-315. http://dx.doi.org/10.1525/ aa.1965.67.2.02a00010.

Fomin, Sergey 1991. "Chitaiushchii da razumeet..." (Prorochestva o sud'bakh Rossii). Prorochestva o sud'bakh Rossii) [“Let the Reader Understand...”: Prophecies about the Destiny of Russia.] Nash sovremennik, No. 9, pp. 120-129.

Frankfurter, David 2006. Evil Incarnate: Rumors of Demonic Conspiracy and Satanic Abuse in History. Princeton: Princeton University Press.

Fuller, Robert C. 1995. Naming the Antichrist: The History of an American Obsession. New York \& Oxford: Oxford University Press.

Gorski, Philip S. \& Kim, David Kyuman \& Torpey, John \& VanAntwerpen, Jonathan (eds.) 2012. The Post-Secular in Question: Religion in Contemporary Society. New York \& London: New York University Press.

Habermas, Jurgen 2006. Religion in the Public Sphere. European Journal of Philosophy, Vol. 14, No. 1, pp. 1-25. http://dx.doi.org/10.1111/j.1468-0378.2006.00241.x.

Heath, Chip \& Bell, Chris \& Sternberg, Emily 2001. Emotional Selection in Memes: The Case of Urban Legends. Journal of Personality and Social Psychology, Vol. 81, No. 6, pp. 1028-1041. http://dx.doi.org/10.1037/0022-3514.81.6.1028.

Hofstadter, Richard 1965 [1952]. The Paranoid Style in American Politics and Other Essays. New York: Knopf. 
Karpov, Vyacheslav 2010. Desecularization: A Conceptual Framework. Journal of Church and State, Vol. 52, No. 2, pp. 232-270. http://dx.doi.org/10.1093/jcs/csq058.

Knight, Peter 2000. Conspiracy Culture: From the Kennedy Assassination to The X-Files. New York \& London: Routledge.

Lewis, James R. 2001. Satanism Today: An Encyclopedia of Religion, Folklore, and Popular Culture. Santa Barbara \& Denver \& Oxford: ABC-CLIO.

Lyon, David 1994. The Electronic Eye: The Rise of Surveillance Society. Minneapolis: University of Minnesota Press.

Marcus, George E. (ed.) 1999. Paranoia within Reason: A Casebook on Conspiracy as Explanation. Chicago \& London: The University of Chicago Press.

Meletiy 2001 = Meletii, Mitropolit Nikopol'skii. Pechat' antikhrista v pravoslavnom predanii. [The Imprint of the Antichrist in the Orthodox Tradition.] Transl. from Modern Greek. Moscow: Izdatel'stvo sestrichestvo vo imia prepodobnomuchenitsy velikoi kniagini Elizavety. Available at http://www.wco.ru/biblio/books/meletn2/ main.htm, last accessed on May 12, 2017.

Molokotos-Liederman, Lina 2003. Identity Crisis: Greece, Orthodoxy, and the European Union. Journal of Contemporary Religion, Vol. 18, No. 3, pp. 291-314. http:// dx.doi.org/10.1080/13537900310001601677.

Moore, Robert I. 2007 [1987]. The Formation of a Persecuting Society: Authority and Deviance in Western Europe 950-1250. Oxford: Blackwell.

Oring, Elliott 2014a. Memetics and Folkloristics: The Theory. Western Folklore, Vol. 73, No. 4, pp. 432-454. Available at https://www.questia.com/library/ journal/1P3-3636001441/memetics-and-folkloristics-the-theory, last accessed on May 12, 2017.

Oring, Elliott 2014b. Memetics and Folkloristics: The Applications. Western Folklore, Vol. 73, No. 4, pp. 455-492. Available at https://www.questia.com/library/ journal/1P3-3636001451/memetics-and-folkloristics-the-applications, last accessed on May 12, 2017.

Pelkmans, Mathijs \& Machold, Rhys 2011. Conspiracy Theories and Their Truth Trajectories. Focaal: Journal of Global and Historical Anthropology, Vol. 59, pp. 66-80. http://dx.doi.org/10.3167/fcl.2011.590105.

Pipes, Daniel 1997. Conspiracy: How the Paranoid Style Flourishes and Where It Comes From. New York: Free Press.

Pokrovskiy \& Zolnikova 2002 = Pokrovskii, Nikolai \& Zol'nikova, Natalia. Staroverychasovennye na Vostoke Rossii XVIII-XX vv.: Problemy tvorchestva i obshchestvennogo soznaniia. [The Chasovennye Old Believers in the East of Russia from the 18th to the 20th Centuries: Aspects of Cultural Heritage and Social Imagination.] Moscow: Pamiatniki istoricheskoi mysli.

Popper, Karl Raimund 1962. Conjectures and Refutations: The Growth of Scientific Knowledge. New York \& London: Basic Books.

Popper, Karl Raimund 1966 [1962]. The Open Society and Its Enemies. Vol. 2. The High Tide of Prophecy: Hegel, Marx and the Aftermath. 5th rev. London \& Henley: Routledge.

Relfe, Mary Stewart 1981. When Your Money Fails: The 666 System Is Here. Montgomery, AL: Ministries, Inc. 
Relfe, Mary Stewart 1982. The New Money System 666. Montgomery, AL: Ministries, Inc. Rosenwein, Barbara H. 2010. Problems and Methods in the History of Emotions. Passions in Context, Vol. 1, No. 1, pp. 1-32. Available at http://www.passionsincontext.de/ uploads/media/01_Rosenwein.pdf, last accessed on May 12, 2017.

Rothstein, Mikael 2004. Science and Religion in the New Religions. In: James R. Lewis (ed.) The Oxford Handbook of New Religious Movements. Oxford: Oxford University Press, pp. 99-118.

Russele, Kati 2015. Religiia i sovremennye tekhnologii, ili Protivorechivoe mirovozzrenie pravoslavnykh khristian. [Religion and Modern Technologies, or the Contradictions of the Orthodox Worldview.] In: Zhanna Kormina \& Aleksander Panchenko \& Sergei Shtyrkov (eds.) Izobretenie religii: desekuliarizatsiia v postsovetskom kontekste. [Invention of Religion: Desecularization in Post-Soviet Context.] St. Petersburg: Izdatel'stvo Evropeiskogo universiteta v Sankt-Peterburge, pp. 46-62.

Serzhantov, Pavel 2007-2008. Pravoslavie i kharizmatizm. [Orthodoxy and Charismatic Christianity.] Al'fa i Omega, No. 49, pp. 148-168; No. 50, pp. 116-152; No. 51, pp. 113-144. Available at http://www.pravmir.ru/alfa-i-omega/, last accessed on May 12, 2017.

Shuck, Glen W. 2005. Marks of the Beast: The Left Behind Novels and the Struggle for Evangelical Identity. New York \& London: New York University Press.

Soboleva, Larisa 1997. Amerikanskoe sochinenie ob Antikhriste - komp’iutere v interpretatsii ural'skogo starovera. [An American Essay on the Computer-Antichrist Interpreted by an Old Believer from the Urals.] In: T. Volklova et al. (eds.) Issledovaniia po istorii knizhnoi i traditsionnoi narodnoi kul'tury Severa. [Studies in the History of Literary and Popular Culture of the North.] Syktyvkar: Izd-vo Syktyvkar. un-ta, pp. 118-130.

Stanton, Don E. 1977. Mystery 666. Secunderabad, India: Maranatha Revival Crusade. Tayson 1980 = Taison, Vera. Prezhde i teper'. [Then and Now.] Vera $i$ Zhizn', No. 29, pp. 25-26. Available at http://www.lio.ru/files/images/magazines/vera/ attachments/vera-1980-2.pdf, last accessed on July 3, 2017.

[Tayson V.] 1989. Vsemirnyi zagovor: Chislo 666. [A Global Conspiracy: The Number 666.] Put'spaseniia. Nezavisimyi dukhovno-prosvetitel'nyi al'manakh drevlepravoslavnykh russkikh khristian $v$ rasseianii sushchikh, No. 3, pp. 13-16.

Tayson 1993 = Taison, V. Taina sataninskogo chisla "666". [The Secret of the Satanic Number 666.] Sochi: Khristianin i Vremia.

[Vaulin, Pavel R.] 1981. Nastuplenie zveria. [The Attack of the Beast.] Niva: Illustrirovannyi zhurnal literatury $i$ sovremennoi zhizni, Vol. 9, No. 45, pp. 3-6.

Verkhovskiy 2003 = Verkhovskii, Aleksandr. Politicheskoe pravoslavie: Russkie pravoslavnye natsionalisty $i$ fundamentalisty, 1995-2001 gg. [Political Orthodoxy: Russian Orthodox Nationalists and Fundamentalists in 1995-2001.] Moscow: Tsentr "Sova".

Webber, David F. \& Hutchings, Noah 1978. The Computers Are Coming. Oklahoma City: Southwest Radio Church.

Weber, Max 1989. Science as a Vocation. In: Peter Lassman \& Irving Velody \& Herminio Martins (eds.) Max Weber's 'Science as a Vocation'. London: Unwin Hyman Inc., pp. 3-32. 
West, Harry G. \& Sanders, Todd (eds.) 2003. Transparency and Conspiracy: Ethnographies of Suspicion on the New World Order. Durham \& London: Duke University Press.

Wood, Gordon S. 1982. Conspiracy and the Paranoid Style: Causality and Deceit in the Eighteenth Century. The William and Mary Quarterly, Vol. 39, No. 3, pp. 401-441. http://dx.doi.org/10.2307/1919580. 


\title{
RUMOUR AND HUMOUR IN \#WHEREIsPUTIN AND \#PUTINUMER: GLOBAL MEDIA AND THE CULT OF PUTIN
}

\author{
Liisi Laineste \\ Department of Folkloristics \\ Estonian Literary Museum, Estonia \\ e-mail: liisi@folklore.ee \\ Eda Kalmre \\ Department of Folkloristics \\ Estonian Literary Museum, Estonia \\ e-mail:eda@folklore.ee
}

\begin{abstract}
The article analyses rumours about Putin's disappearance from the public eye during the ten-day period in March 2015. Parallels with earlier rumours about Russian leaders before Putin are thus revealed and differences between English and Russian sources of information are pointed at.

The data presented here comes from both traditional and social media: the global official news coverage of Putin's disappearance, and the unofficial information spread in social media via Twitter hashtags \#WhereIsPutin and \#PutinUmer. Using this data, the authors describe the differences between English- and Russian-language social media sources and indicate the recurring and more influential belief motifs in the stories told about the political leaders in Russia in the junction of various genres (above all rumour, humour, and news). The analysis sheds light on the inner workings of rumour and humour in social media. The comparison shows that even if the world is a 'global village' and news, travelling fast, quickly become known around the world, there is a fissure between the content and the ways particular events or cases get represented in the official media outlets and social media. The differences arise from the cultural and historical context of the producers and consumers of the news: collective memory, folklore, vernacular belief, etc.
\end{abstract}

Keywords: conspiracy theories, contemporary legend, humour, infotainment, newslore, Putin, rumour, Russia 
Twenty-first-century Ostankino mixes show business and propaganda, ratings with authoritarianism. And at the centre of the great show is the President himself, created from a no one, a gray fuzz via the power of television, so that he morphs as rapidly

as a performance artist among his roles of soldier, lover, barechested hunter, businessman, spy, tsar, superman. 'The news is the incense by which we bless Putin's actions, make him the President,' $T V$ producers and political technologists liked to say. Peter Pomerantsev (2014) ${ }^{1}$

\section{INTRODUCTION}

On the evening of January 26,2015 , Russian social media started to buzz with stories about Vladimir Putin (b. 1952), President of Russia, having allegedly had a heart attack. The rumour started from the news about Moscow Red Square being closed off by the federal security forces on that day. Rumours about Vladimir Putin's health problems stopped after the head of the state was seen again in public, chairing a meeting of the Security Council of the Russian Federation. Although these stories lasted for a very short time, they caused considerable reverberation in the unofficial media channels dominated by grassroots journalism. ${ }^{2}$ However, it is worth noting that this was neither the first nor the last time that similar speculations about Vladimir Putin stirred up a storm in both online and offline media channels in Russia; furthermore, these stories had also been circulating about other Russian leaders.

In March 2015, Putin disappeared from the view of the media for more than a week, which is a long time considering that since his ascent to authoritarian power Putin has been a star figure in the media, "reigning on the screen unchallenged" (Sperling 2016; Abdullaev 2010). Immediately, numerous speculations and rumours arose concerning the reasons of his disappearance. Analysing this gives an insight into the workings of the contemporary information society and its need for infotainment, but even more so into the long-running beliefs held by the people who are discussing the topic. Next to the more traditional media, alternative information channels - e.g. social media outlets - are available nowadays. Participatory media in the form of citizen journalism are booming and ideas about the truth-value of news are changing as well. ${ }^{3}$ However, online and offline media are followed by different audiences (Oates \& Lokot 2013): the choice of media channels is more a matter of intent and preferences than opportunity (the same can be said about the media in other authoritarian systems; see, e.g., Astapova 2015: 23). 
This article addresses the media behaviour and rumours concerning Putin's disappearance from the public eye during the ten-day period in March 2015, and discusses them in the light of classical negatory rumours and legend $\mathrm{s}^{4}$ from history. The theoretical backdrop for the discussion is set by folkloristic theories of rumour and conspiracy, but also those of online communication and humour. The data analysed here consists of two equally important sources: global news coverage of Putin's disappearance, and the information spread in social media via English- and Russian-language Twitter hashtags \#WhereIsPutin and \#PutinUmer. Based on our results, we describe how news spread on the global arena, compare the English- and Russian-language social media sources dealing with the topic, and, last but not least, show what the reoccurring (and most influential) motives are in the stories told about the political leaders in Russia, and how they reappear in present-day internet folklore concerning Putin. The analysis sheds light on the inner workings of rumour and humour in social media, taking the incident of Putin gone missing as a case in point.

\section{RUMOURS ABOUT THE (ETERNAL) LIFE OF THE HERO}

"Life would be boring without rumours," stated Putin to reporters in his first public event since March 15, referring to rumours about his 10-day absence earlier that month (Birnbaum \& Murphy 2015). Earlier observations confirm that the more prominent an event or person is, the more folklore it generates: "a story that is strong on prominence and novelty but weak on impact is likelier to generate a folkloric response... [it] is likelier to generate newslore that targets the news media" (Frank 2011: 168). Shekshnia, Puffer, and McCarthy (2009: 325) have described how the leaders of the society as well as minorities use mythology in the broad sense (stories, jokes, tales, songs, supernatural events, and characters) to influence and educate people. This mythology reflects culture and is accepted in the eyes of most of the people. The observation can be easily applied to present-day Russia as well.

But prominence in the present-day media scene also means visual presence and power. All the news almost exclusively requires providing a visual - better yet, audio-visual - account of the event. The importance of the visual is deeply rooted in evolutionary processes, but online media has brought it into the limelight. Mieke Bal (2003: 11) has noted that a "vision is always implicated in a knot of power and knowledge". Seeing is believing, as the saying goes, and our reality depends on what we are shown in the media, whereas the accessibility to information is in turn controlled by power. Sanja Bjelica (2015) connects the furore following Putin's media absence in March 2015 to 
the centralised power established in Putin's figure - his actual, everyday physiological presence in photographs and film. In politics appearance is everything, and it is even truer in the image-centred culture of the present times. ${ }^{5}$ Putin has been turned into a spectacle (Simons 2014): what we know about Putin is dependent on how he appears in the media. In the official media channels, such images are presented in an overly positive context. We are to believe the attractiveness, virility, masculinity, and firmness of the autocrat, as they all are integral parts of the image of the man (see Figs. 11-13). This illustrates the point that visual representation and what it conveys - intentionally or unintentionally - is one of the prime mechanisms of meaning-making (Demski \& Laineste \& Baraniecka-Olszewska 2015).

In order to understand and analyse the diversity of today's highly visual and humorous culture (e.g. memes on the Internet), we need to know its folkloric foundation and building blocks.

Rumours have always abounded in Russia from the Tsarist era to the postSoviet times (Ortmann \& Heathershaw 2012: 551). Rumours were especially predominant in the Soviet Union, particularly in the period up to Stalin's death, where they were indeed the main substitute for news. This situation lasted until the collapse of the Soviet regime (Kalmre 2013a: 17). Even though spreading anti-regime rumours (as well as telling jokes) has always been a risky endeavour under totalitarian circumstances (Oring 2016: 110, 128, and elsewhere; Kalmre 2013a: 18-19), this has never stopped people from sharing them. Regardless of their abundance, there is only little research done on the issue (Ortmann \& Heathershaw 2012; Kalmre 2013a: 18-19), and this study seeks to fill this gap.

Today's lore is based on stories and beliefs that were known already long ago in more or less recognisable form. Typical examples of negatory rumours known from history refer to beliefs about the death or secret life of a leader or celebrity. The beliefs rely on a simple psychological mechanism: we both deny and fear the death of known persons, and also toy with the idea of hated leaders' undercover, secret life. ${ }^{6}$ The characteristic feature of negatory rumours is the hypercritical pattern of thinking - this is evident in the suspicions about both real and imagined events that are described in the stories. Negatory rumours open up or expose another reality, truer than the present one. It means that every negatory rumour is coupled with an assertive rumour, replacing the denied reality with a new one. It is indeed difficult to provide evidence for this other reality, as Renard (2005: 225) asserts, not because this other reality is an illusion, but because proofs are systematically being suppressed or hidden. As a result, speculations concerning the whereabouts and identity of the targets of rumour arise: the dead are actually not dead or the living are in fact dead, being replaced by their lookalikes, etc. (ibid.: 224-226). 
Negatory rumours and legends about political figures are very similar to stories about pop idols. The rumours include their death, lookalikes, resurrection, etc. Folk theories and rumours about Elvis Presley being still alive present a case in point. They convey beliefs about a second reality within the society obsessed with entertainment; a reality where no wish remains unfulfilled. Such rumours are based on the deification of the hero (usually after their death, but in some cases also before it) and their composition can in many ways be traced back to the stories about the figure of Jesus Christ (Dundes 2007). The pop hero lives as if in two worlds - in the one we live in and in another one created by the media and popular culture through photographs, movies, and advertisements. In that beautiful desired world heroes live on after their death as idols and objects of consumption (Stromberg 1996: 290-295). This is the ground that has given rise to mythology about Putin (see Arkhipova 2015). It carries characteristics similar to stories about the Belarusian president Lukashenka and other authoritarian leaders (Astapova 2016).

We need to keep in mind, though, that deification of pop idols that are created by people themselves primarily for entertainment and pleasure purposes differs from the cult of political leaders, whose image is more serious, as is their profession and role in society. Let us compare, for example, rumours about Putin to those about the death of Stalin and/or his replacement with a lookalike. Stalin's person had been mythologised in several different ways: he was an omnipotent god, but also a monster and trickster. Attitudes towards him showed a mixture of devoted admiration and mockery, envy and anger (Kalmre 2013a: 48; see also Krikmann 2003: 94-95). His death was both hoped and feared for. Arvo Krikmann has described the phenomenon of Orwellian "doublethinking" based on the stories about Stalin's noble descent. This notion involves both fanatical worship and paralysing fear of the leader (Krikmann 2003: 195; see also Kalmre 2013a: 50). People remember the cult of Stalin as something all-embracing and powerful:

We were taught...above all, we were taught to love Comrade Stalin. The first letter we ever wrote was addressed to him in the Kremlin. Here is how it happened... Once we had learned the alphabet, they handed out white sheets of paper and dictated a letter to our most benevolent, most beloved leader. We loved him so much, we really believed that he would answer our letters and sends us presents. Lots of presents! We would stare at his portrait and think he was so handsome. The most handsome man in the world! We even argued over who would give up more years of their life for a day of Comrade Stalin's. (Alexievich 2016: 231)

We can notice that some elements are the same (depicting Putin as an omnipotent god, a cult figure as well as a joke character), but Putin's cult also 
bears features similar to the worship of pop idols or that of Western politicians (e.g. Reagan; see Street 2004 on celebrity politicians). During his 16 years in office, he has become an idol, a sex symbol, and a superhero due to his public relations team and their clever and skilful media strategies. Songs are created about him, he flies with the cranes, dives into the depths of water as an archaeologist, plays with a tiger, rides horses bare-chested in scenic locations. At the same time, he has become the central figure in Russian political humour and now embodies numerous stereotypes known from previous leaders in the state's history (Mallinen \& Hytönen 2015: 8-9). This is quite expected in the atmosphere of suppressed self-expression and censorship and a limited right to participate in political life. Thus, next to the officially circulated, flattering images of Putin, there are the ironical and humorous ones that compete with the former (although the audiences may not completely converge). Grassroots journalism is prone to use an ironic stance that Frank (2011: 166-188) captures in his notion of folk media criticism. Newslore as a form of folk media criticism contains a mixture of entertainment, explanations, and hypotheses. This easily breeds humour, mixing together different genres, which in turn are motivated by the sandwiching of serious news between commercials, serials, comedies, and other essentially incompatible genres (see Davies 1999; Ellis 2005; Kuipers 2011; Oring 2003). These different genres (including jokes, rumours, and legends) are forms of collective behaviour and ways of relieving social, political, and economic tensions and, as such, tell a great deal about the society. Gary Alan Fine (2007: 5) posits that researching rumours "reaches the heart of what it means to have a public sphere, a space of common discourse in which a community collectively judges whether truth claims are to be accepted and responded to". The genres also get along well: they provide the necessary living conditions for each other, address the same topics with a different degree of belief, they spread information and knowledge, and they help negotiating the hardships of everyday life (Ellis 2005: 126 and elsewhere; see also Best 2005). The plots of beliefs and rumours solidified in the collective memory find a suitable outlet in the visual humour on the Internet.

Laughter performs two major functions in this simultaneous struggle for both the truth and entertainment - it challenges power hierarchies and draws new audiences, expanding the circle of those protesting against the way the media present the news (Makarychev 2013: 654). The images of the ridiculous Other (caricatures, photoshopped images or mashups, etc.) contest the established power hierarchies. As a reaction, power might strike back: there have been cases of punishing acts of humorous diversion in Russia, the punk group "Pussy Riot" being the most notorious example of anti-Putin and -government actions being sanctioned (Gabowitsch 2013). Humour as a way to subvert power 
is acknowledged as a potential risk by joke-tellers as well (for a Belarusian example, see Astapova 2015: 38).

Aleksandra Arkhipova (2015) claims that people create political mythological narratives of their leaders if they believe their life and health depends on the autocrat. During late years of socialism, gerontocracy sparked stories about the ailing, dying leaders of Russia. When Leonid I. Brezhnev, Yuri V. Andropov and Konstantin U. Chernenko died in quick succession, the public was among the last to be informed. While usually the health of heads of state in other countries is public knowledge, and citizens have the right to know when and why their leader is in hospital and who runs the state in their place, then in the case of Russia these questions are subject to mystification.

It is interesting that the belief in the lookalikes of politicians can be interpreted differently. This collective belief is tied to the phenomenon of death and partly also deification, but whereas the popular heroes are suspected of still being alive (though undercover), then the politicians' lookalikes bring forth another side of the issue: it might not be the politicians themselves who are to be blamed for the mismanagement of the country but instead it is the fault of their doubles or subordinates (Mallinen \& Hytönen 2015: 12). This motif of lookalikes has been very productive. It has given inspiration for fictional texts, for example, movies (there is a film about Lenin's doubles, built on the theory that Lenin had been long dead before the revolution started (Kalmre 2013b: 37; see also My Lenins, Estinfilm 1997). There were also rumours about Yeltsin's death; for example, that he had been dead since August 1999 (when Putin succeeded him as President) and his doppelgänger acted as him until 2007. ${ }^{7}$ All in all, we can say that the reputed death, disappearance, doubles, and secret life of heroes have been and still are the most productive and prominent topics in belief narratives and culture in general. It is an endless source of inspiration for the entertainment business and social media today.

\section{REVERBERATIONS OF PUTIN'S DISAPPEARANCE IN OFFICIAL NEWS SOURCES AND TWITTER}

The time period covered in this study ranges from March 5 until March 25, 2015. The aim was to get an overview of reactions from all the phases of the media event (the beginning, peak, and end). Overall posting frequency shows that there were not many rumours, stories or other kind of reactions until March 11; they peaked in the following five days and lasted well after Putin's appearance on March 15 (or even peaked the second time, in the case of Russianlanguage tweets; see Fig. 3), gradually disappearing later on. This follows the 
usual popularity curve of internet memes (Bauckhage 2011). To contextualise the stories that arose about Putin's disappearance, let us first look at the official global media coverage and then turn to the alternative information and entertainment channel, namely Twitter.

\section{Analysis of news with the GDELT}

The GDELT (Global Database of Events, Language and Tone, founded by Kalev Leetaru in 2013) ${ }^{8}$ comprises news texts covering more than 30 years, and collecting news from 64 languages from all around the world. It offers a variety of tools and services that allow to visualise, explore, and export the data. The GDELT analysis shows that intensive news coverage of the incident started on March 10, first in the Russian-language press. North American press soon followed, peaking on March 12, but the number of news texts published in Russian press remained higher (see Fig. 1). A visualisation of the data in Gephi revealed two main, sparsely interconnected sets of news texts: largely the Russian-language / neighbouring Eastern European countries versus Englishlanguage / the rest of the world. This shows that the media of these two regions refer mainly to sources within the regions and do not refer to each other across the imaginary borders.

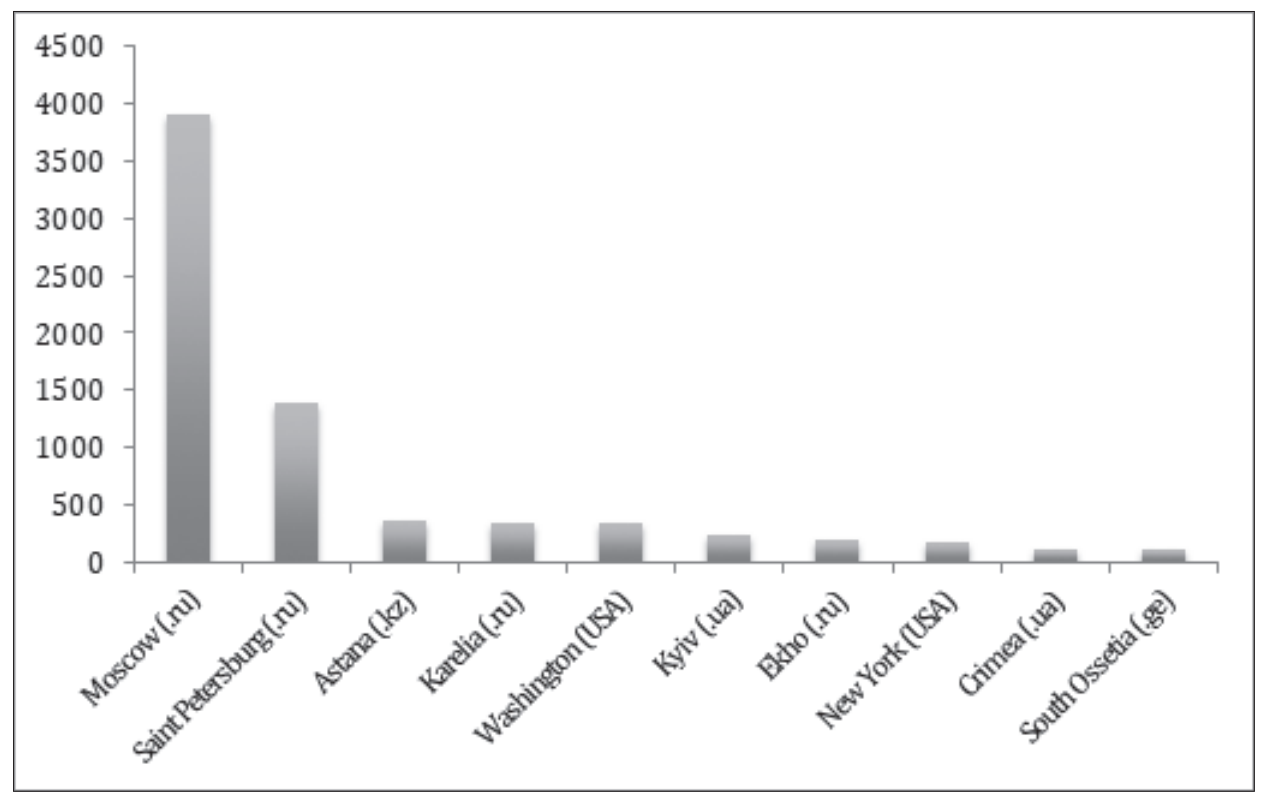

Figure 1. Keywords 'Putin' / 'info: rumour' / 'Russia'; combined search on the GDELT. Most of the sites are from Russian-language media (accessible for audiences who speak Russian). 


\section{Analysis of social media: Twitter threads \#PutinUmer and \#WhereIsPutin}

The aim of analysing the Twitter feed during Putin's ten-day disappearance was to compare English- and Russian-language channels, looking at the rumours that evolved, their intensity and content, and the visual format they took. This gives an insight into the global character of the rumours and humour around the disappearance of Putin, and helps to indicate the local features that accompanied their representation. Through the use of the two hashtags, \#PutinUmer and \#WhereIsPutin, tweets spread quickly.

There are some characteristic features to the Russian media that shaped the public reception in that area, especially the gap between the state-controlled media and a relatively free online sphere, but also a distinct audience divide of not only online/offline but also younger/older generation, with television and its viewers being supporters of the regime, and the internet audience the opponents (for an in-depth discussion, see Oates \& Lokot 2013). Thus the Twitter reactions studied here are mostly representative of the ideas and beliefs of the younger, technologically savvy media generation. These contrasts and social cleavages do not apply to the English-language coverage of Putin's disappearance.

The overall tendencies of dissemination of \#PutinUmer and \#WhereIsPutin are visualised in Figure 2, which depicts the different durations and intensities of tweeting about the event in the English or Russian language. There was a considerable overlap of themes and images in the two channels, which shows that cross-referencing between Twitter hashtags of various origin and in different languages might be more frequent than in the case of traditional media (e.g. as compared to the GDELT results, which suggest there was not much overlap between Russian and all other media).

The analysis of the Twitter threads shows that the hashtags in question discuss similar topics, although the sharing starts earlier and lasts longer in \#PutinUmer, whereas it starts later and is more intensive in \#WhereIsPutin. The most usual first reaction is to question the truth value of the news. Twitter users ask one another: "Is he really dead?" Being unsure about the answer, but already critical about the media that spread the news, they reply: "Who knows, but Twitter has definitely already buried him." State symbols were brought to bear: it was rumoured that the flag was missing from Kremlin tower - a sign that something had happened in the government. Additional tweets hinted that the flag was being washed because it had been stained with blood (after the alleged coup). Alternative theories posited that Putin was either ill, very seriously ill, had had a heart attack (possibly from the excessive use of Viagra - another example 


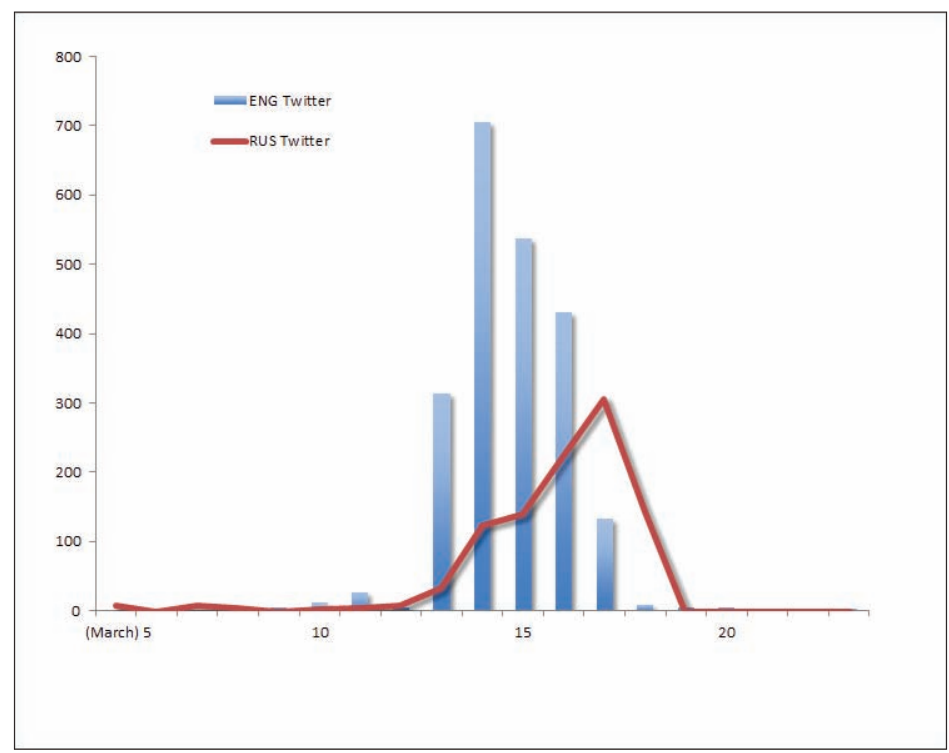

Figure 2. Russian- and English-language Twitter hashtags \#PutinUmer and \#WhereIsPutin, posts per day, from March 5 to March 25 (both text and images). ENG Twitter = \#WhereIsPutin, represented in the figure with a line; RUS Twitter $=$ \#PutinUmer, represented in the figure with columns.

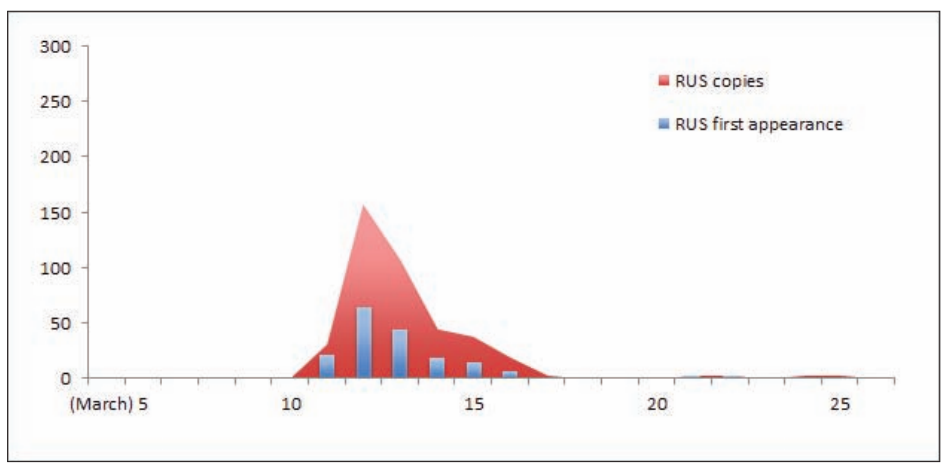

Figure 3. \#PutinUmer: total of memes (area) and first occurrences (columns).

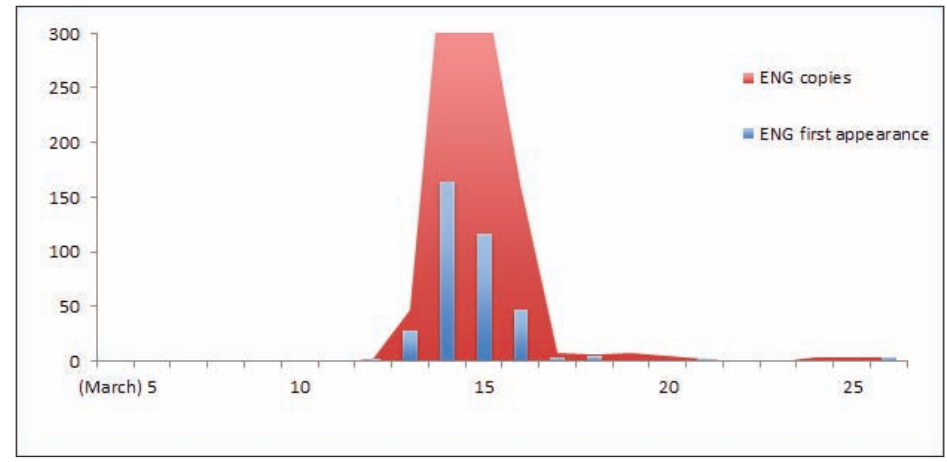

Figure 4. \#WhereIsPutin: total of memes (area) and first occurrences (columns). 
of the foregrounded (although dubious) masculinity of Putin), was dead, had been deposed by a former advisor, was planning an international military attack, was present at the birth of his love child (with Alina Kabaeva), was having (another) plastic surgery, etc. References to popular belief were present; for example, hearsay about astrologists having foreseen that Russia will lose its leader in 2015, or allusions to Friday 13 as a significant date, which was also the most intensive day of news coverage about Putin both in the official media and Twitter.

Serious discussions were replaced by humorous ones after a few days. Here, the English-language hashtag for sending memes was used with greater intensity than the Russian one (see Figs. 3-4).

It is the death of the omnipresent and -potent leader that worried the people most. He was portrayed on his deathbed, in the coffin, at a funeral, in a mausoleum, while the visual elements used were borrowed from various genres (comics, documentary photography, or even medical realm, e.g. radiology). As the crisis in Ukraine was still in full swing at the time, numerous tweets connected Putin's disappearance to this political conflict, some of them addressing it through humour (Figs. 5-6).

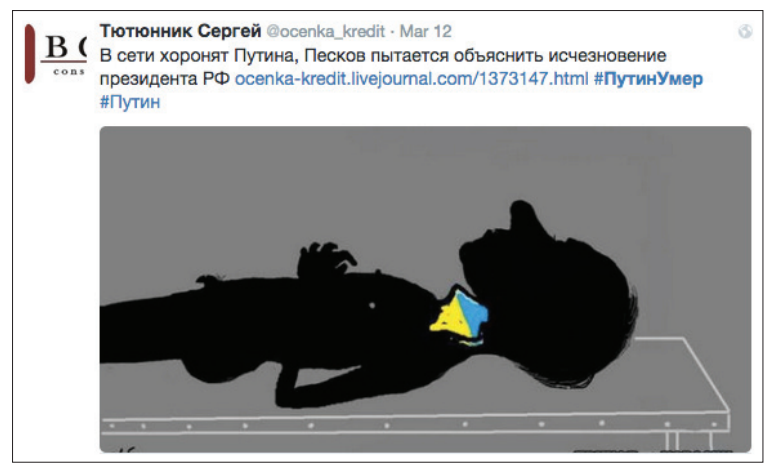

Figure 5. Putin has choked swallowing Ukraine - represented by the colours of the Ukrainian flag (blue and yellow) in his throat (Twitter, March 12, 2015).

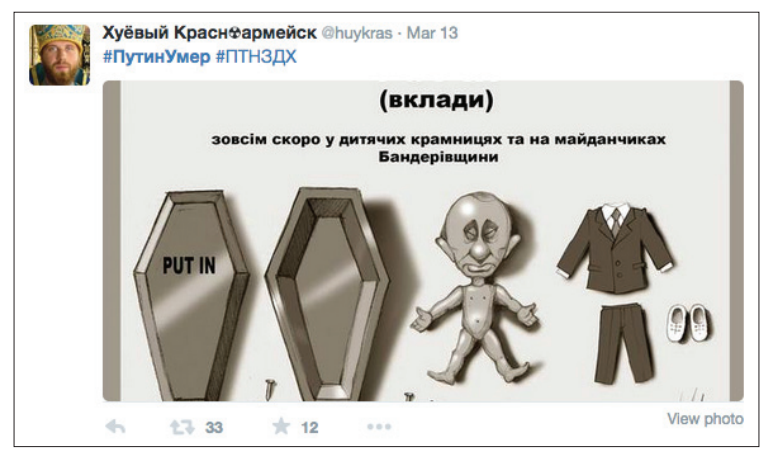

Figure 6. Put in: Very soon in children's stores all across Ukraine (Twitter, March 13, 2015). 
Others are less openly humorous, presented as clever and skilful collages and mashups, peppered with references to previous Russian leaders. A closer look at these images reveals that the background for the two "bodies" is the same (Figs. 7-8).
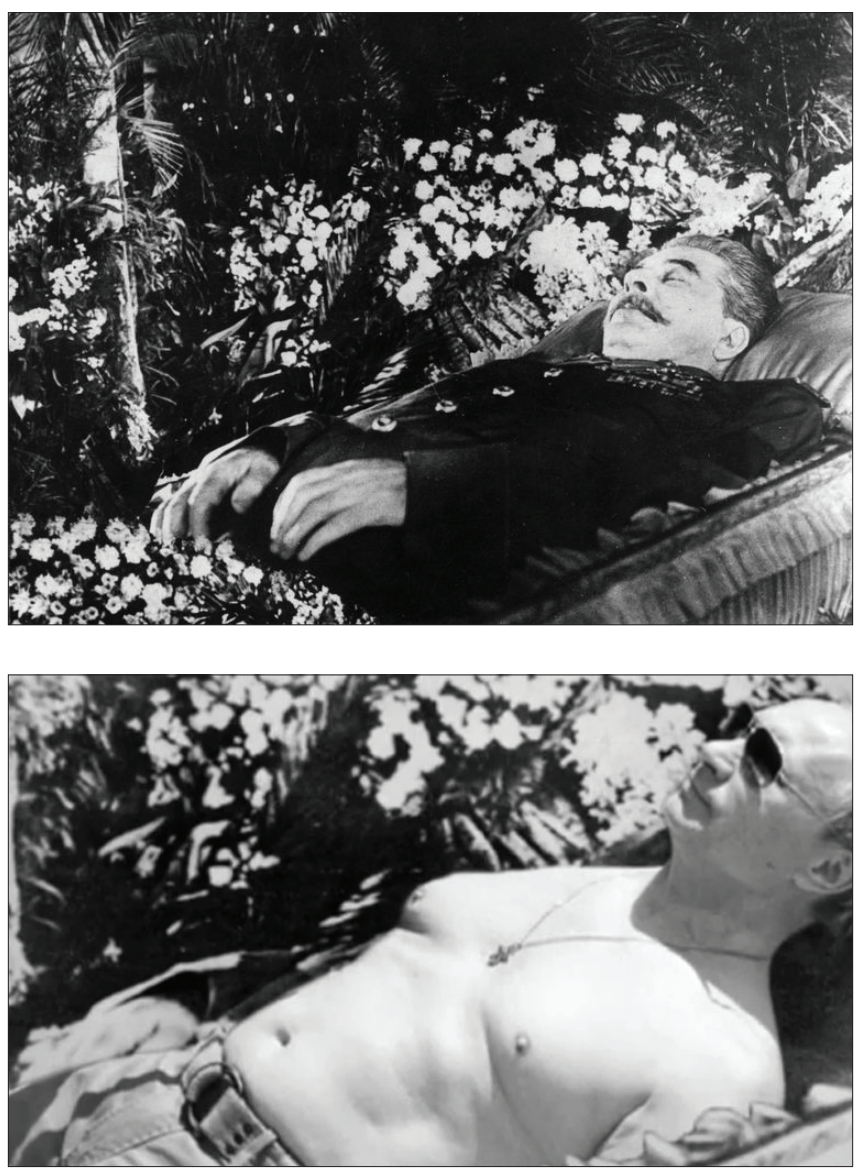

Figures 7 and 8. Stalin (original; http://mrelliottscoldwar.weebly.com/stalin.html) and Putin (collage; https://pbs.twimg.com/media/B_2PV1TVEAAoYls.jpg).

Yet others offer new images, which do not rely on prior acquaintance with the Russian culture or the funeral traditions of local leaders, but present a universally understandable visual answer to solve the mystery of Putin's disappearance (Fig. 9). 


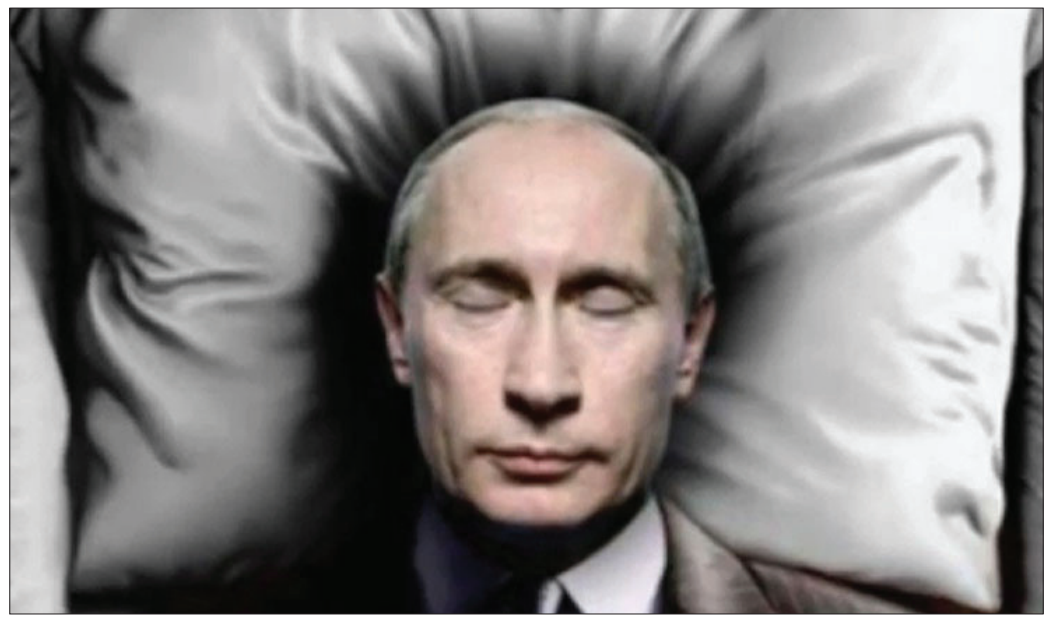

Figure 9. Putin in a coffin (https://inmoscowsshadows.files.wordpress. com/2015/03/putindead.jpeg).

An alternative stream of messages acknowledges the fact that Putin is missing, but suggests that reasons for it are unclear. As long as there is undeniable evidence that he is dead, him being missing may mean various, sometimes highly creative or totally absurd options, serious or funny. It is significant that some of the first tweets (images) point at his inactivity in social media: "Putin missing? Putin's Twitter not updated since March 6th" ${ }^{9}$ Others list a number of available hypotheses: "Five theories on \#WhereIsPutin: 1) stroke; 2) coup; 3) more Botox; 4) new kid; 5) (Ukrainian version) he has been anally probed by space aliens" (Twitter, John Sweeney, March 14). Universal references abound: "Where's Waldo?"-style pictures with a hidden Putin among the characters, or "Missing Putin" written on cartons of milk in the vein of "face on a milk carton" trope often used in American culture. There are plenty of photoshopped memes expressing suspicion about the conspiracy that he has been replaced (by other people or by a cardboard effigy). People claim that identical photographs of Putin in meetings were used in the press to calm people down. For example, almost identical photographs from 2014 and 2015 circulated as memes (see Fig. 10).

People actively present their versions of who the best lookalike for Putin is (actors, animals, portraits by known artists, characters from popular culture e.g. Dobby from the novel/movie Harry Potter). All these suggestions play on the reader's cultural knowledge and provide a humorous effect by merging together seemingly incompatible spheres of meaning. 


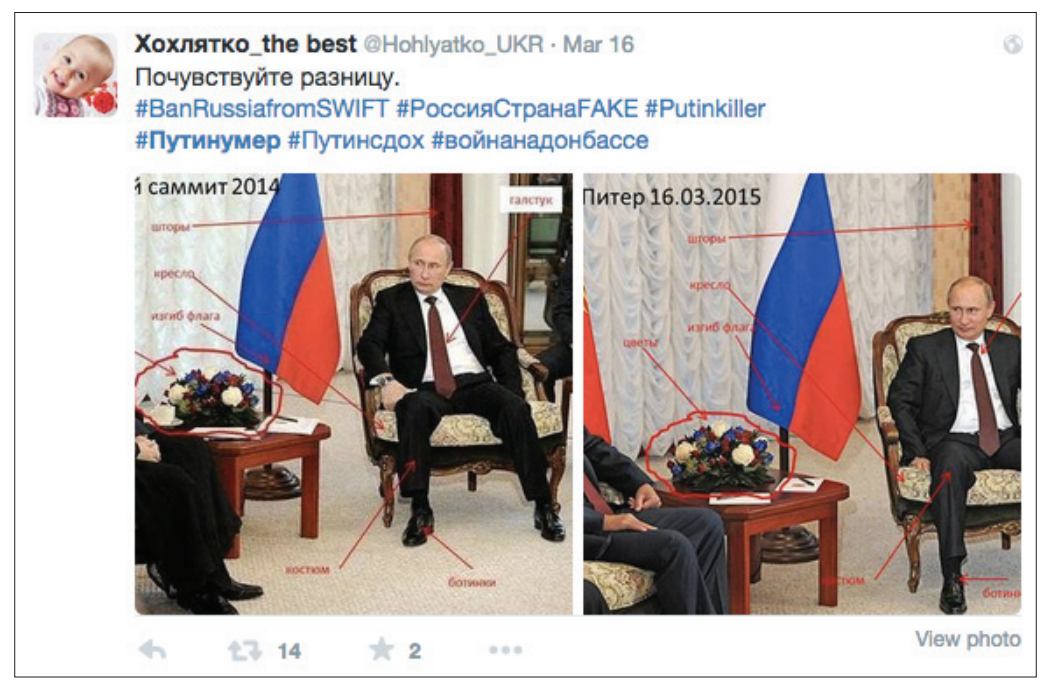

Figure 10. Identical photographs of Putin's press conferences from 2014 and 2015 (Twitter, March 16).

The second equally important and quantitatively even larger category of memes triggered by the news of Putin gone missing is that of a postmodern hypermasculine superhero taken to the extreme. This motif is inspired by Putin's character in the media discussed earlier - he is a father of the nation, wages wars and bombs the enemies, flies with the storks and rides in the outback, features in songs, artworks, calendars, etc. References to riding several objects (cookies, horses, bears, eagles, the Moon) offer an absurd visualisation of this (Fig. 11).

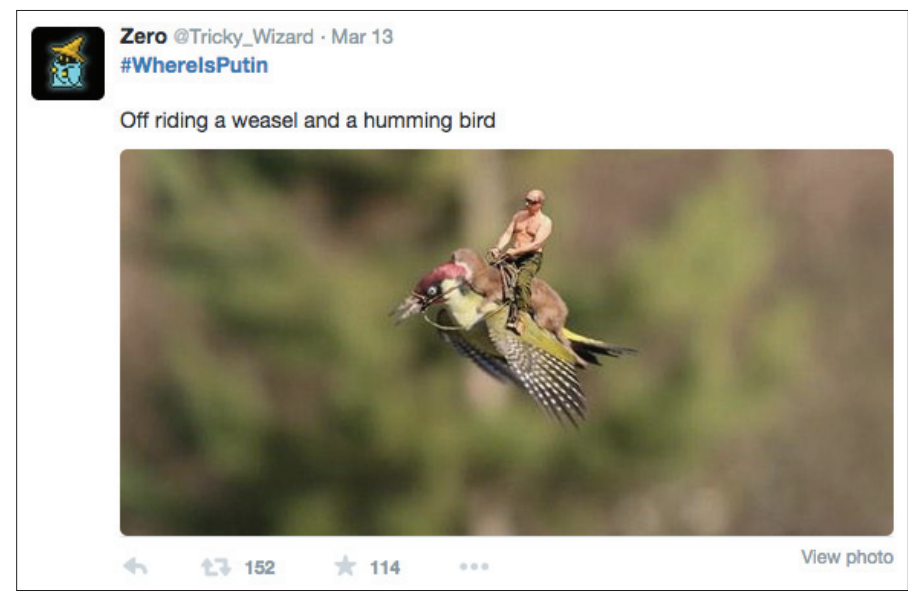

Figure 11. Off riding a weasel and a humming bird meme (Twitter, March 13). 
The meme better known under the name of WeaselPecker dates back to March 2, only a few days before Putin's disappearance, which is why it is not surprising that these two blend into imaginative remixes. Discussions abounded whether the weasel riding on a woodpecker is a fake or not (see, e.g., Bittel 2015). Harmonising pleasantly with Putin's fascination for riding and nature, the image and its numerous derivatives were some of the more popular Putin memes at the time.

References to symbols of virility were present in those images: Putin was depicted as a giant penis (see Fig. 12); yet, his masculinity was also questioned, for example in the theories that he was missing it because of the side effects of excessive Viagra. The feminisation of Putin on photoshopped images produced popular memes of Putin in a ballet skirt, with heavy make-up, or sporting huge breasts (Fig. 13). This refers to the varied hypotheses of Putin's nip and tuck surgery or Botox treatments.

Feminisation, together with state-sanctioned homophobia and traditional macho ideology, is a powerful strategy that Putin's supporters have used against the opposition, for instance, in the war with Ukraine (Romanets 2017), while his own image is that of the masculine, unbreakable man. There is a tension between the official homophobic policy advocated by the Russian government and the 'folk' depiction humorously accusing Putin of being gay. The multiple folk imagery of Putin as a woman and a gay simultaneously ridicules the official image of him as the powerful leader and a masculine man. Alan Dundes has

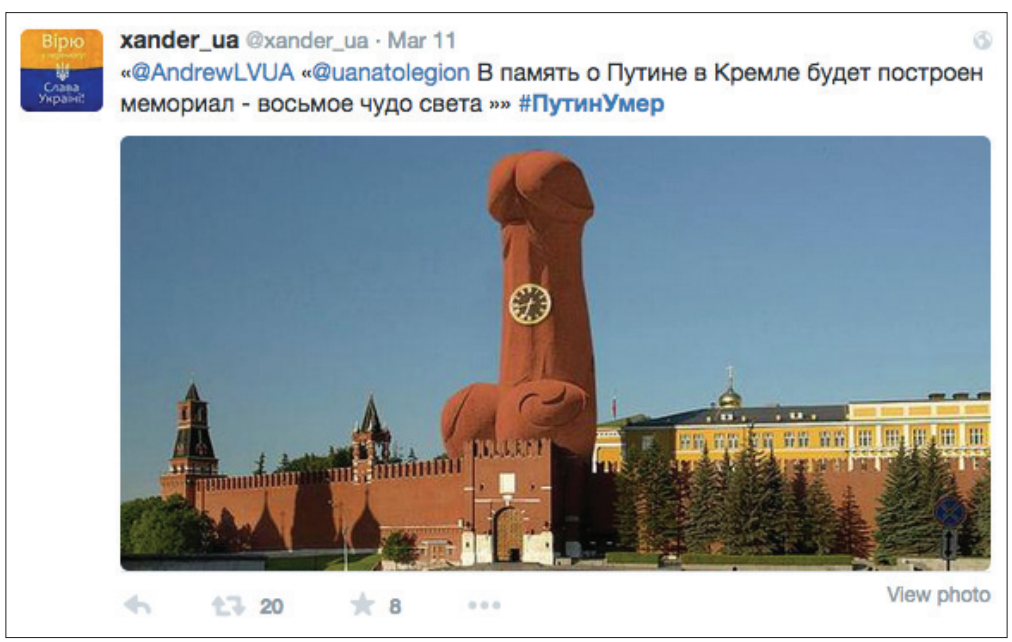

Figure 12. To commemorate Putin, a memorial will be built in Kremlin - the eighth wonder of the world (Twitter, March 11). 


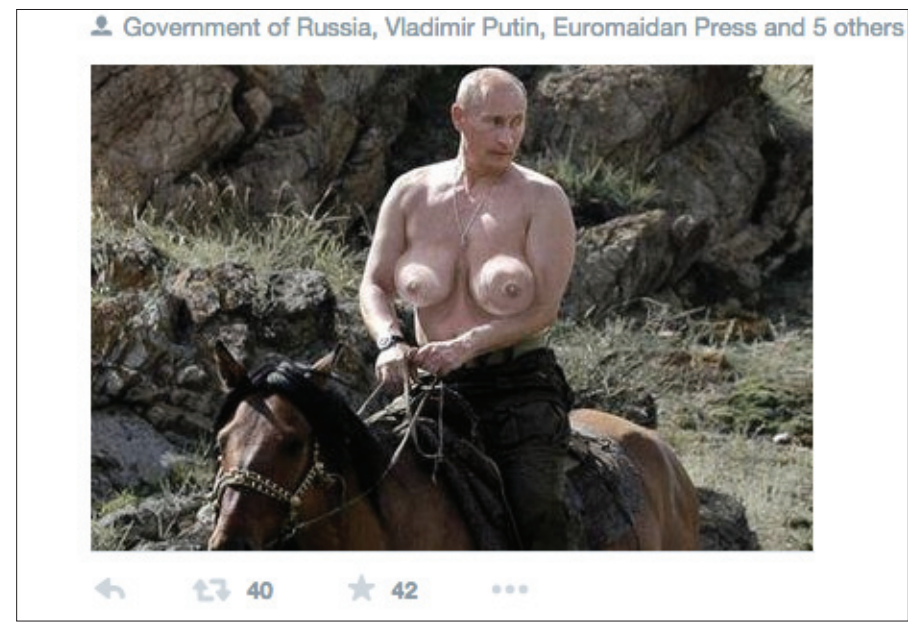

Figure 13. Putin riding a horse after aesthetic surgery (Twitter, March 13).

described similar processes in American football, where the feminisation and stigmatisation of the competitor is a strategy to gain the upper hand (Dundes 1978: 79, 85, and elsewhere). A clear use of the hypermasculinity motif was present when Putin's spokesman Mr. Peskov commented on the disappearance to the journalists and used an old 'joke' from Yeltsin's time. Namely, when Boris Yeltsin had gone missing once again, he was said to still have a firm handshake and be busy working on documents. Peskov tuned this up a little and added, "Mr. Putin's handshake could break hands" (MacFarquhar 2015).

\section{CONCLUSION}

The comparison between the content of the two hashtags, \#PutinUmer (Russian-language) and \#WhereIsPutin (English-language) highlights a number of features specific to either Russian- or English-language tweets. Firstly, the Russian-language Twitter thread was more constrained and cautious. There were questions (particularly in the beginning) about whether it was really happening or whether it was true, but no one was ready to give answers. Secondly, it dwelled longer on the possible theories of why Putin was missing, discussing their truth value, referring back to different symbols (the missing flag on Kremlin tower, Stalin's death date - March 5 - coinciding with the date of Putin going missing, etc.) to find support to these hypothetical scenarios. Thirdly, there were numerous references to earlier motifs from folk belief, rumour, 
and other elements of popular culture that are known strictly within Russian cultural space (e.g. Tchaikovsky's ballet "Swan Lake" being on TV - according to common knowledge in Russia this is usually shown when the government wants to hide something, a statement bordering between a rumour and a joke).

On the other hand, even though the English-language tweets about Putin borrowed from the Russian ones in the beginning (because the rumours started earlier in \#PutinUmer, and only later infiltrated into \#WhereIsPutin), they carried also some characteristic features, firstly greater variability of topics covered. The nationalities of the people using the \#WhereIsPutin thread were more varied, hence also the greater number and variety in the forwarded memes. Retweets reached a higher number, at times even over 300 (compared to some dozens in \#PutinUmer). Secondly, the focus was above all on conspiracy stories - the more unreal and absurd the better (clones, doppelgängers, lookalikes, beauty surgery, etc.). The exaggeration of the issue added a strong humorous overtone (contrary to the initially rather constrained style in Russian-language tweets). Thirdly, the variety of specific folk rumour references was not that big in \#WhereIsPutin. This is understandable, given that the Russians are much more intimately acquainted with the Russian leader-related myths and theories (e.g. the Swan Lake reference which is very specific to Soviet times). Last but not least, there were numerous references to Western pop culture symbols, icons, texts, and popular memes of the time.

Sharing images was common to both Russian- and English-language channels (e.g. Fig. 10, Putin in a press conference). There were cross-references to theories and jokes, and an active communication went on between the users of the two hashtags.

The comparison shows clearly that even if the world is a 'global village' and news, travelling fast, quickly become known around the world, there is a fissure between the content and the ways that particular events or cases get represented in the official media outlets and social media. The differences arise from the cultural and historical context of the producers and consumers of the news: collective memory, folklore, vernacular belief, etc. The elements visible in the top layer of daily interactions - sometimes disseminated through humour - are actually informative of the deep, entrenched layers of culture.

The question that interests us is why rumours about Putin take off so easily. The reasons are at least fourfold. Putin is an autocratic leader who holds and executes power in Russia, thus the change in leadership would cause great changes. Even if that was to please some people from the opposition, such changes would still make the society nervous. In addition to this, Putin is omnipresent in Russian mediascape and his lengthy and unexplained absence is always significant for the (local) public. Furthermore, official explanations do 
not always satisfy people because Putin's politics concerning the press gives prevalence to government-minded channels, and many people do not trust the news. The depiction of Putin in various media differs across sources: Simons (2014) has described how conservatives in the United States consider the current president of Russia an honest, courageous man with high ideals about his state and nation. For the majority of Russians, he is portrayed as the Father of the Nation (Mikhailova 2013), with only an occasional tinge of irony (Goscilo 2013). In the international media, however, Putin is represented as a negative character (Simons 2015: 205; for a discussion of exceptions, see Simons 2014).

As Russia did not develop into a democratic and open society after the Soviet Union's demise (and its mainstream media as well as the majority of alternative media channels ${ }^{10}$ are under state control), rumours about the political leaders and the economic and political circumstances still disseminate covertly. Addressing or researching them freely is problematic. It is important, however, for the society to study collective beliefs expressed through rumour because through these stories a great deal can be found out about that society (Kalmre 2013a: 23). As collective talk, rumour is tied to ideas of how society should be properly organised. Rumours like jokes give an opportunity to talk about things that would otherwise be quieted; they convey messages that would be difficult or impossible to express directly (Neubauer 1999: 169; Oring 2016: 117). Rumours that help to verbalise fear and uncertainty are especially important for people living in undemocratic and authoritarian societies. In some circumstances, we incorporate rumours into our belief system, act upon them, and recall them through collective memory (Fine 2007: 5-6) more than in others. The official media and rumours can mutually reinforce each other in a symbiotic relationship (Emde 2005). Social media comprises a huge community with a multitude of smaller sub-divisions, connected as a giant network pulsing with information. It makes all information increasingly accessible to people worldwide, doing it usually quicker than the traditional media. Consequently, news reporting becomes more emotional, faster, and personal. The Arab Spring, the Occupy Wall Street movement, Tahrir Square, the Euromaidan events in Ukraine, and many others are but some examples where grassroots journalism played a huge and influential role.

In order to explain the rumours about President Putin, his historical predecessors and folkloric belief concerning Russian rulers have to be examined. The same factors are at stake that gave rise to legends about Stalin, Brezhnev, Yeltsin or the tsars prior to them. Putin's shaping into a full-blown folk hero started hand in hand with his sudden coming to power in the year 1999, and since then the process has taken almost ridiculous dimensions. The mass media 
makes sure that the wider public is constantly being informed about the details of his life. This gives an illusion that everything is known about him - or that actually nothing is known, as we dig deeper into the information. There are many theories about his origins or private life, but no marker of their truth value. The elements of his early life and later relationships are being constantly reinterpreted (a tendency similar to a number of known figures). These so-called vernacular biographies are by no means clear-cut stories of a hero; rather, they are a medley of official representations, altered narratives, literary productions, and quotes ascribed to that person (Astapova 2016). The stories are propped up by real, strong emotions - love, fear, and hate. ${ }^{11}$

In Putin's case there are always sources to refer back to: the collective history, belief narratives, and memories about the previous leaders in Russia function as a vast pool of stories. Arkhipova, in her essay about the connections between earlier rumours about Russian leaders, writes that all the versions of Putin's disappearance are rooted in folk stories from before - for example with Putin, as with Stalin's disappearance in 1937, people suspected him of having gotten secretly married (besides being dead or having been replaced by a lookalike; see Arkhipova 2015).

Rumours about Putin are further fuelled by motives of previous stories in the collective memory (e.g. stories about doubles or early death), gaining selective importance within the contemporary Russian media that leaves much untold. Lack of relevant information is water to the mills of people's imagination. Particularly in the countries with centralised authoritarian power structure, where one leader decides everything and where there is a general shortage of information, people sincerely believe that the health and whims of the leader decide their fate. This fact forces them to construct their reality by using known mythological models, negatory ideas, and rumours. Alongside this, people become extremely suspicious and make attempts at revealing the 'truth'. Generally, when speaking about online media, serious belief (or disbelief) tends to be marginalised there and a humorous mode prevails (e.g. Danet 1995; Danet \& Ruedenberg-Wright \& Rosenbaum-Tamari 1997). Drawing from the present study, the entertainment/infotainment value is definitely foregrounded on the Internet, especially in the non-Russian material. 


\section{ACKNOWLEDGEMENTS}

This research is related to the research project "Narrative and belief aspects of folklore studies" (IUT 22-5) (Estonian Ministry of Education and Research, Estonian Research Council) and was supported by the European Union through the European Regional Development Fund (Centre of Excellence in Estonian Studies).

\section{NOTES}

1 See http://www.e-reading.club/bookreader.php/1037451/Pomerantsev_-_Nothing_Is_ True_and_Everything_Is_Possible_The_Surreal_Heart_of_the_New_Russia.html, last accessed on September 19, 2017.

${ }^{2}$ Grassroots journalism (also termed citizen journalism) is the practice of newsgathering and reporting by public citizens. It plays an active role in the process of collecting, analysing, and disseminating news and information (Gillmor 2004).

3 See discussions about the post-truth society, e.g. Bennett 2016 [1983].

4 "Rumours are called negative when they state facts associated with fear or hostility. We speak of negatory ideas and rumours when commonly accepted events are denied" (Renard 2005: 223).

5 "Through the power of photography, Putin is singlehandedly shaping the image of contemporary Russia. In politics, appearance is everything; words are secondary. This has never been truer than in the image-driven culture of the 21st century, when, in true nihilistic spirit, we don't believe in what we cannot see" (Bjelica 2015).

6 According to the international type index, the two main motives are A570 ("Culture hero still lives") and A580 ("Culture hero's expected return") (Thompson 1955-1958; see also https://en.wikisource.org/wiki/Page:Thompson_Motif-Index_2nd_1.djvu/130, last accessed on September 19, 2017).

7 Yeltsin might have died last year, a Russian internet media site reports (see http:// epl.delfi.ee/news/valismaa/Yeltsin-vois-surra-moodunud-aastal-kirjutab-veneveebileht?id=50822378, last accessed on September 19, 2017). This fake news also spread as a chain letter (Eda Kalmre's comment).

8 See http://gdeltproject.org/, last accessed on September 19, 2017.

9 YouTube, Elite NOW agenda, posted March 15, 2015 (see https://www.youtube.com/ watch?v=9S1Df8iQtoM, last accessed on September 19, 2017).

${ }^{10}$ During recent years, Russia has exerted control over the Internet and social networks (see Gerden 2015; Benyumov 2016).

11 This is reflected also in jokes about Stalin (see Krikmann 2004: 43), in which the totalitarian leader is shown as a lover of macabre humour at the expense of others. 


\section{REFERENCES}

Abdullaev, Nabi 2010. Medvedev Digs into United Russia. The Moscow Times, November 25. Available at http://www.themoscowtimes.com/news/article/ medvedev-digs-into-unitedrussia/424588.html\#no, last accessed on September 20, 2017.

Alexievich, Svetlana 2016. Secondhand Time: The Last of the Soviets. New York: Random House.

Arkhipova, Aleksandra 2015. Slukh o nem proshel po vsei Rusi velikoi. [Rumour about Him Spread All Over Great Russia.] Gazeta.ru, March 15. Available at https://www.gazeta.ru/politics/2015/03/15_a_6599953.shtml, last accessed on September 19, 2017.

Astapova, Anastasiya 2015. Negotiating Belarusianness: Political Folklore Betwixt and Between. Dissertationes Folkloristicae Universitatis Tartuensis 22. Tartu: University of Tartu Press. Available at http://dspace.ut.ee/handle/10062/49509?localeattribute=en, last accessed on September 19, 2017.

Astapova, Anastasiya 2016. Political Biography: Incoherence, Contestation, and the Hero Pattern Elements in the Belarusian Case. Journal of Folklore Research, Vol. 53, No. 2, pp. 31-62. http://dx.doi.org/10.2979/jfolkrese.53.2.02.

Bal, Mieke 2003. Visual Essentialism and the Object of Visual Culture. Journal of Visual Culture, Vol. 2, No. 1, pp. 5-32. http://dx.doi.org/10.1177/147041290300200101.

Bauckhage, Christian 2011. Insights into Internet Memes. Proceedings of the Fifth International AAAI Conference on Weblogs and Social Media, pp. 42-49. Available at http://www.aaai.org/ocs/index.php/icwsm/icwsm11/paper/download/2757/3304, last accessed on September 19, 2017.

Bennett, Lance W. 2016 [1983]. News: The Politics of Illusion. Tenth edition. Chicago: University of Chicago Press.

Benyumov, Konstantin 2016. How Russia's Independent Media Was Dismantled Piece by Piece. The Guardian, May 25. Available at https://www.theguardian.com/ world/2016/may/25/how-russia-independent-media-was-dismantled-piece-bypiece, last accessed on September 20, 2017.

Best, Joel 2005. Fashion, Topical Jokes, and Rumor as Short-Term Enthusiasms. In: G. A. Fine \& V. Campion-Vincent \& C. Heath (eds.) Rumor Mills: The Social Impact of Rumor and Legend. New Brunswick, New Jersey: Aldine Transaction, pp. 173-187.

Birnbaum, Michael \& Murphy, Brian 2015. Putin Surfaces after Mysterious 10-Day Absence. Washington Post, March 16. Available at https://www. washingtonpost.com/world/europe/putin-makes-first-public-appearance-sincemarch-5/2015/03/16/6088ab20-cbcb-11e4-8c54-ffb5ba6f2f69_story.html?utm _ term $=.86 \mathrm{a} 6930315 \mathrm{c} 1$, last accessed on September 20, 2017.

Bittel, Jason 2015. Weasel Rides Woodpecker in Viral Photo - But Is It Real? National Geographic, March 4. Available at http://news.nationalgeographic.com/ news/2015/03/150303-weasels-woodpeckers-animals-science-weaselpeckerphotos/, last accessed on September 19, 2017. 
Bjelica, Sanja 2015. Putin's Muscular Politics and the Power of Photography. Balkanist, May 23. Available at http://balkanist.net/putin-photography/, last accessed on September 19, 2017.

Danet, Brenda 1995. General Introduction: Playful Expressivity and Artfulness in Computer-Mediated Communication. Journal of Computer-Mediated Communication, Vol. 1, No. 2. http://dx.doi.org/10.1111/j.1083-6101.1995.tb00323.x.

Danet, Brenda \& Ruedenberg-Wright, Lucia \& Rosenbaum-Tamari, Yehudit 1997. "Hmmm...where' that smoke coming from?" Writing, Play and Performance on Internet Relay Chat. Journal of Computer-Mediated Communication, Vol. 2, No. 4. DOI: 10.1111/j.1083-6101.1997.tb00195.x.

Davies, Christie 1999. Jokes on the Death of Diana, Princess of Wales. In: Tony Walter (ed.) The Mourning for Diana. Oxford \& New York: Berg Publishers, pp. 253-271.

Demski, Dagnosław \& Laineste, Liisi \& Baraniecka-Olszewska, Kamila (eds.) 2015. War Matters: Constructing Images of the Other (1930s to 1950s). Budapest: L'Harmattan.

Dundes, Alan 1978. Into the Endzone for a Touchdown: A Psychoanalytic Consideration of American Football. Western Folklore, Vol. 37, No. 2, pp. 75-88. http://dx.doi. org/10.2307/1499315.

Dundes, Alan 2007. The Meaning of Folklore: The Analytical Essays of Alan Dundes. Edited by Simon J. Bronner. Logan, Utah: Utah State University Press.

Ellis, Bill 2005. Legend/Antilegend. Humor as an Integral Part of the Contemporary Legend Process. In: G. A. Fine \& V. Campion-Vincent \& C. Heath (eds.) Rumor Mills: The Social Impact of Rumor and Legend. New Brunswick, New Jersey: Aldine Transaction, pp. 123-140.

Emde, Sina 2005. Feared Rumours and Rumours of Fear: The Politicisation of Ethnicity During the Fiji Coup in May 2000. Oceania, Vol. 75, No. 4, pp. 387-402. http:// dx.doi.org/10.1002/j.1834-4461.2005.tb02898.x.

Fine, Gary Alan 2007. Rumour, Trust and Civil Society: Collective Memory and Cultures of Judgment. Diogenes, Vol. 54, No. 1, pp. 5-18. http://dx.doi. org/10.1177/0392192107073432.

Frank, Russell 2011. Newslore: Contemporary Folklore on the Internet. Jackson: University Press of Mississippi.

Gabowitsch, Mischa 2013. Putin kaputt!? Russlands neue Protestkultur. Berlin: Suhrkamp Verlag.

Gerden, Eugene 2015. Russia to Strengthen State Control over the Internet. SC Media UK, April 20. Available at https://www.scmagazineuk.com/russia-to-strengthenstate-control-over-the-internet/article/537529/, last accessed on September 20, 2017.

Gillmor, Dan 2004. We the Media: Grassroots Journalism by the People, for the People. Sebastopol, CA: O'Reilly Media.

Goscilo, Helena 2013. Putin's Performance of Masculinity: The Action Hero and Macho Sex-Object. In: Helena Goscilo (ed.) Putin as Celebrity and Cultural Icon. Abington: Routledge, pp. 180-207.

Kalmre, Eda 2013a. The Human Sausage Factory: A Study of Post-War Rumour in Tartu. Amsterdam \& New York: Rodopi. 
Kalmre, Eda 2013b. Rumours and Contemporary Legends as Part of Identity Creation Process. In: Liisi Laineste \& Dorota Brzozowska \& Władysław Chłopicki (eds.) Estonia and Poland: Creativity and Tradition in Cultural Communication. Volume 2: Perspectives on National and Regional Identity. Tartu: ELM Scholarly Press, pp. 25-42.

Krikmann, Arvo 2003. Luuseri pihtimus. [Loser's Confession.] In: Arvo Krikmann \& Sirje Olesk (comps.) Võim \& Kultuur. Tartu: EKM Teaduskirjastus.

Krikmann, Arvo 2004. Netinalju Stalinist / Internet-anekdoty o Staline / Internet Humour about Stalin. Tartu: EKM Teaduskirjastus. Available at http://www.folklore. ee/ kriku/HUUMOR/STALIN_FIN.pdf, last accessed on September 20, 2017.

Kuipers, Giselinde 2011. Where Was King Kong When We Needed Him? Public Discourse, Digital Disaster Jokes, and the Functions of Laughter After 9/11. In: Ted Gournelos \& Viveca Greene (eds.) A Decade of Dark Humor: How Comedy, Irony and Satire Shaped Post-9/11 America. Jackson: University Press of Mississippi, pp. 20-46.

MacFarquhar, Neil 2015. Putin Has Vanished, but Rumors Are Popping Up Everywhere. New York Times, March 13. Available at https://www.nytimes.com/2015/03/14/ world/europe/russia-putin-seen-in-public.html, last accessed on September 19, 2017.

Makarychev, Andrey 2013. The Culture of Protest: Counter-Hegemonic Performances in Putin's Russia. The Russian Review, Vol. 72, No. 4, pp. 653-657. DOI: 10.1111/ russ.10712.

Mallinen, Jukka \& Hytönen, Ville 2015. Putin tuli külla: Vene poliitika metsikuimad naljad. [Putin Came to Visit: Wildest Political Jokes in Russia.] Tallinn: Tänapäev.

Mikhailova, Tatiana 2013. Putin as the Father of the Nation: His Family and Other Animals. In: Helena Goscilo (ed.) Putin as Celebrity and Cultural Icon. Abington: Routledge, pp. 65-81.

Neubauer, Hans-Joachim 1999. The Rumour: A Cultural History. London \& New York: Free Association Books.

Oates, Sarah \& Lokot, Tetyana 2013. Twilight of the Gods?: How the Internet Challenged Russian Television News Frames in the Winter Protests of 2011-12. Paper prepared for the Post-Socialist and Post-Authoritarian Communication Working Group International Association for Media and Communication Research Annual Conference, Dublin, Ireland, June 2013. http://dx.doi.org/10.2139/ssrn.2286727.

Oring, Elliott 2003. Engaging Humor. Urbana \& Chicago: University of Illinois Press.

Oring, Elliott 2016. Risky Business: Political Jokes under Repressive Regimes. In: Joking Asides: The Theory, Analysis, and Aesthetics of Humor. Boulder, CO: Utah State University Press, pp. 109-128.

Ortmann, Stefanie \& Heathershaw, John 2012. Conspiracy Theories in the Post-Soviet Space. The Russian Review, Vol. 71, No. 4, pp. 551-564. http://dx.doi.org/10.1111/ j.1467-9434.2012.00668.x.

Pomerantsev, Peter 2014. Nothing Is True and Everything Is Possible: The Surreal Heart of the New Russia. New York: PublicAffairs. Available at http://www.e-reading. club/bookreader.php/1037451/Pomerantsev_-_Nothing_Is_True_and_Everything_Is_Possible__The_Surreal_Heart_of_the_New_Russia.html, last accessed on September 19, 2017. 
Renard, Jean-Bruno 2005. Negatory Rumors: From the Denial of Reality to Conspiracy Theory. In: G. A. Fine \& V. Campion-Vincent \& C. Heath (eds.) Rumor Mills: The Social Impact of Rumor and Legend. New Brunswick, New Jersey: Aldine Transaction, pp. 223-240.

Romanets, Maryna 2017. Virtual Warfare: Masculinity, Sexuality, and Propaganda in the Russo-Ukrainian War. East/West: Journal of Ukrainian Studies, Vol. 4, No. 1, pp. 159-177. DOI: http://dx.doi.org/10.21226/T26880.

Shekshnia, Stanislav V. \& Puffer, Sheila M. \& McCarthy, Daniel J. 2009. Cultural Mythology and Global Leadership in Russia. In: Eric H. Kessler \& Diana J. WongMingJi (eds.) Cultural Mythology and Global Leadership. Cheltenham, UK \& Northampton, MA: Edward Elgar, pp. 325-342.

Simons, Greg 2014. Putin's International Supporters. Ul brief No 3. Swedish Institute of International Affairs. Available at https://www.ui.se/globalassets/butiken/uibrief/2014/putins-international-supporters.pdf, last accessed on September 19, 2017.

Simons, Greg 2015. Aspects of Putin's Appeal to International Publics. Global Affairs, Vol. 1, No. 2, pp. 205-208. http://dx.doi.org/10.1080/23340460.2015.1020727.

Sperling, Valerie 2016. Putin's Macho Personality Cult. Communist and PostCommunist Studies, Vol. 49, No. 1, pp. 13-23. http://dx.doi.org/10.1016/j. postcomstud.2015.12.001.

Street, John 2004. Celebrity Politicians: Popular Culture and Political Representation. The British Journal of Politics and International Relations, Vol. 6, No. 4, pp. 435-452. http://dx.doi.org/10.1111/j.1467-856X.2004.00149.x.

Stromberg, Peter 1996. Elvis Alive? The Ideology of American Consumerism. In: Gillian Bennett \& Paul Smith (eds.) Contemporary Legend: A Reader. New York \& London: Garland Publishing, Inc., pp. 289-298.

Thompson, Stith 1955-1958. Motive-Index of Folk-Literature: A Classification of Narrative Elements in Folktales, Ballads, Myths, Fables, Medieval Romances, Exempla, Fabliaux, Jest-Books, and Local Legends. Vols. 1-6. Bloomington: Indiana University Press. 


\title{
WOMEN-SNIPERS FROM CHECHNYA TO UKRAINE: A POST-SOVIET WAR LEGEND
}

\author{
Amandine Regamey \\ University Paris I, France \\ CERCEC (EHESS / CNRS) \\ e-mail: amandine.regamey@gmail.com
}

\begin{abstract}
Among the rumours that circulated in the Russian army in Chechnya in the first decade of the twenty-first century, one of the most widespread involved women-snipers, former biathlon champions from the Baltic states, who allegedly fought alongside Chechen militants. More than ten years later, the rumour surfaced once again in Ukraine. This article explores the different aspects of a war legend that was born among soldiers, was embodied in fiction and popular culture, and used in official propaganda. It shows that the focus on Baltic mercenaries allows to present Russia simultaneously as the successor of the Soviet Union fighting against fascism, and as a state besieged by Islamic terrorism and American expansionism. The fact that women served as snipers in the Soviet army in the Second World War may give to the legend its particular post-Soviet characteristics, but the strength of the legend comes also from its embodying the fear of threatened masculinities. The conclusion reflects on the possible impact of the legend for civilians in areas torn by war, and on the ethical issue it raises for the researcher.
\end{abstract}

Keywords: Baltic states, Chechnya, masculinity, propaganda, Russia, snipers, Ukraine, war legend, women

Among the rumours that circulated in the Russian army in Chechnya, one of the most widespread involved women-snipers, former biathlon champions from the Baltic states, who allegedly fought alongside Chechen militants. Beginning in 1994, the so-called "White Tights" featured in media reports, in official political or military declarations, but also in films, books, and songs.

Twenty years after, Ukrainian Deputy Minister of Youth and Sports, a former Olympic champion in the Ukrainian women's biathlon team, was accused on Russian television of working as a sniper and killing civilians and children in the eastern Ukrainian town of Slavyansk. ${ }^{1}$ While she refuted these allegations as "part of Russian propaganda", she suggested that "perhaps these 'journalists' decided to recall this old story with the Baltic biathletes who allegedly fought in Chechnya". ${ }^{2}$ 
References to these so-called women-snipers have surfaced in all the conflicts of the post-Soviet space: Nagorno-Karabakh, Tajikistan, Transnistria, Abkhazia (Voronov 2004; Ianchenkov 2000). After the rumours of women snipers had surfaced in southern Ossetia in 2008, Russian journalist Oleg Panfilov declared that "these tales, these myths about White Stockings, about Negroes with guns - these are myths that date from the beginning of the 1990s. They were in Abkhazia, and Tajikistan, and in the Fergana Valley, and always, for some reason, these same sharpshooters from the Baltics in white tights, and Negroes, if I may say so". ${ }^{3}$

The impact of these legends on the ground is twofold. First, when a woman is arrested in or near the battlefield, regardless of the circumstances and of her real role in the army (cook, secretary, nurse, fighter), she is said to be a sniper. "If you are detained - that's it, you're a sniper," writes Russian journalist and former serviceman Arkady Babchenko, "even if you were just going to the market for potatoes. The fact that you are detained is already evidence" (Babchenko 2016). In 2001, General Gennady Troshev, head of the North Caucasus military district, explained in an interview that he had met women fighters during his military career and that "most of them were snipers". ${ }^{4}$ In Ukraine, when Ukrainian military pilot Nadezhda Savchenko was captured in June 2014 by pro-Russian separatists, she was accused on Russian television of being a "well-trained" sniper. ${ }^{5}$ After Ukrainian forces had arrested three women among separatist forces near Slavyansk, the anti-terrorist press centre claimed that "three female snipers surrendered". ${ }^{6}$ Particular media coverage is generally given to the capture of alleged women snipers. When more than a hundred fighters entrenched in the Chechen village of Komsomolskoe capitulated after heavy shelling in March 2000, Lenta.ru's main headline was: "In Komsomolskoe a woman-sniper surrendered". ${ }^{7}$

But there is also another consequence of these rumours: when soldiers are under enemy's sniper fire, they accuse these snipers of being specifically women. According to Russian general Gennady Troshev, at the beginning of the Second Chechen War, ${ }^{8}$ Chechen snipers were particularly active and dangerous and "in those sniper teams there were often women" (Troshev 2001). In a TSN newsreel on March 9, 2015, the Ukrainian journalist reporting about the everyday life of the Donbass battalion explains:

The men admit that here, on the frontline, they are less afraid of tanks or heavy artillery than of the enemy snipers. For this function, on the terrorist side, is carried out by girls. ${ }^{9}$

Stories about women-snipers did not only circulate in the context of post-Soviet local wars. The "Flintenweib", a cruel and sexually depraved woman with a gun, 
was a crucial figure among German Freikorps, who fought in the East after the First World War (Theweleit 1987). It was also central in the representations of German soldiers about the Soviet Army. Soon after the Normandy landings in 1944, allied corps also talked about French female sharpshooters, former mistresses of German soldiers: the rumour was so widespread that the military authorities had to issue an official denial (Beevor 2009: 179; Bourke 1999: 327-328). In Vietnam, where women fought among the Vietminh, American soldiers talked about the mythic "Apache", a sadistic woman-sniper, and the figure of the woman-sniper also features in fiction, such as Stanley Kubrick's Full Metal Jacket (1987). More recently, Turkish officials reported that Serbian mercenaries-snipers, including women, fought alongside Kurdish insurgents. ${ }^{10}$

So what is the specificity of this legend in the post-Soviet space? I will try to answer this question by exploring different aspects of the legend, after having defined what is meant here by "legend" (1). Born among soldiers, the womansniper legend was used in official propaganda (2): it was spread by fiction and popular culture, but echoed soldiers' experience in the field (3). The focus on-Baltic mercenaries allows to depict Russia as simultaneously waging war against fascism, Islamism, and America (4). The historical figures of Soviet female fighters may have given an additional impulse to the legend (5), but its strength comes also from the fact that it embodies the fears of threatened masculinities (6).

\section{LEGENDS AND THE QUESTION OF TRUTH}

Different sources have been used in this research: media articles, internet resources, videos, official declarations, but also fiction, books, and films. Some of them only mention the existence of female snipers, others report elaborated stories, some are clearly fiction while others are news reports. Why, then, use the term legend to unite such different stories?

While there is a growing body of literature on contemporary legends (Oring 1990, 2008; Dégh 1991, 1996; Bennett \& Smith 1996; Campion-Vincent \& Renard 2002; Bennett 2005; Fine \& Campion-Vincent \& Heath 2005; Bonhomme 2009; Fine \& Ellis 2010; etc.), there is still no consensus among researchers either on the term to be used (contemporary, modern or urban legends, myths, rumours, foaf tales, legendry, etc.) or on the exact definition of these legends. Nevertheless, researchers agree on some key aspects that can all be found in the stories about women-snipers mentioned in this paper.

First of all, a "legend is, or approximates, a narrative" (Oring 2008: 128). This criterion is usually used to differentiate legends from rumours: while 
"a rumour is merely a sort of plotless unverified report" (Baky 1994), legends can be defined as a kind of "solidified" rumour (Allport \& Postman 1947: 162), based on a much more constructed and structured narrative. Legends are "not something vague, diffuse and formless like a rumor [...] they are texts rather than shapeless bits of discourse", writes Gillian Bennett (2005: xii).

This difference is exemplified by Gary Fine and Bill Ellis when they explain that "a rumour often is a generalization, stating (for instance) that immigrants 'do' something, while a legend is a specific example, alleging that at a particular time and place immigrants 'did' or 'are about to do' something" (Fine \& Ellis 2010: 4). Indeed, stories about female snipers can be either rumours (which mention the presence of women-snipers among enemy soldiers in Abkhazia, Chechnya, Ukraine, etc.) or legends (which provide the name, details, and deeds of a particular woman). But Fine and Ellis also point out that "the boundaries between the two are hazy, however, and even folklorists and social scientists who study both find themselves hard put to draw a sharp boundary" (Fine \& Ellis 2010: 4). Rumours will thus be included in this case study together with legends, all the more because they often circulate and are transmitted in the same way.

While a rumour is often used as a synonym of "word of mouth", and a legend is said to have "at least part of its origins in oral transmission" (Baky 1994), Dégh and Vázsonyi are of the opinion that "telling, even in folklore, need not always be identical with talking. There are other forms of communication suitable for folklore materials" (Dégh \& Vázsonyi 1983: 5). They mention the increasing influence of mass media, telephone, car and plane travel, to which of course we should now add the Internet and social networks as crucial transmitters of rumours and legends.

The second crucial aspect of legends is their multiplicity. There is a general agreement that, to be called a legend, a story "must exist in more than two variations" (Baky 1994), that "contemporary legend is a type of discourse which (i) may be presented in a multiplicity of forms and media; (ii) exists in multiple versions over time and space" (Bennett \& Smith 1996: xxii) The fact that a story repeats over time, that it can be heard in different historical contexts, is precisely the first indication that it is a legend, but can explain also why legends often "accommodate traditional themes" (Baky 1994). Legends are "those stories that have been around long enough to be instantly recognizable, to have acquired a history, to echo folkloric themes and motifs" (Bennett 2005: xiii). As we will see further on (in the chapter about threatened masculinities), stories of female snipers do indeed incorporate traditional motifs and echo Russian folktales.

These folkloric themes and motifs may involve ghosts or mysterious phenomena, but contemporary legends are not always linked with the supernatural or the uncanny. More generally, "contemporary legend themes are broadly 
thematically related in that they project a dissonant world (iv) which may be bizarre or preternatural... (v) and/or which may involve either explicitly or by implication behaviour that has cultural restraints placed on it" (Bennett \& Smith 1996: xxii).

This third criterion, the notion of the "dissonant world", may be more difficult to identify in war legends because, by definition, these stories happen in a world of war which is already dissonant with the normal world. But all war legends involve, indeed, a behaviour that infringes not only cultural or social norms but also simply the "laws of war": government abandoning its soldiers on a desert island (Gulzow \& Mitchel 1980), soldiers trafficking in organs (Regamey $2012 \mathrm{~b}$ ) or women using arms and spilling blood in spite of an anthropological taboo (Héritier 1996).

Bennett and Smith note also that "the dissonance of the legend world, and the mismatch between it and the life circumstances of tellers and audiences, creates a possibility of (and maybe demand for) some form of active engagement with the legend" (Bennett \& Smith 1996: xxii). Indeed, a legend is not "just a story", and its fourth characteristic is that it engages, in one way or another, both the narrator and the listener. Legends can be told and passed on for a multiplicity of reasons: to illustrate a point, to demonstrate, to test the credibility, to boast of knowledge, to avoid openly expressing an opinion, etc. Whatever the reasons, "consensus has emerged among experts that the proper study of the so-called 'legend' or 'rumour' was not the infinitely varying narrative texts collected by observers, but rather the social process that generated them" (Fine \& Ellis 2010: 4).

Among the reasons why people transmit a rumour or a legend, the notion of belief has gradually been abandoned by researchers (Dégh 1996). Legends can be told, repeated, discussed, and transmitted even without any belief in their content.

We may not find a given story credible; that is, we may find the source of information dubious (and the use of the 'friend of a friend' as the authority has been noted for decades). However, many people will nevertheless discuss and pass on rumours because they contain a plausible claim. (Fine \& Ellis 2010: 5)

This question of credibility and plausibility leads us to the most discussed and controversial issue - the question of truth.

Legends are situated somewhere on a continuum between myth and folktale at one pole, and news and history at the other, moving along this continuum depending on the individual story and the whims or objectives of the individual storyteller who relates it. (Bennett 2005: xi) 
In each of these cases, their relation to the question of truth is different: newsreels or official declarations supposedly report about objective facts, while books and films can openly be fictional. But what unites them is the fact that "the scene is always set in the world as we know it, and the stories seem to be giving information about that world" (ibid.). War films, for example, even if they are based on a completely fictional scenario, pretend to represent the war as it is, to reflect it as faithfully as possible, and several films that feature womensnipers (see the chapter about the legend between popular culture and military experience) are based on historical events and feature historical characters (Chechen and Russian leaders, etc.).

So, on the one hand, legends circulate - if not as true stories - at least as plausible and credible stories. On the other hand, "the assumption that legends (and their cousins, rumours) are false is often implicit, merely an undercurrent to the researcher's work" (Bennett 2005: 304). There seem to be two ways for researchers to deal with this contradiction.

The first approach would be to consider that legends are true in some symbolic kind of way, like myths (ibid.: xi), that these "stories are repeated and circulated because they are true at that indeterminate level between fact and metaphor" (Scheper-Hughes 1996: 5). People may tell stories that are not an "accurate description of what they saw", because these stories nevertheless "carry the values and meanings that most forcibly get their point across" (White 2000: 30). Stories about organ trafficking that circulated in Chechnya in the 2000s conveyed, for example, the sense of horror, inhumanity, and physical destruction experience by Chechens during the war (Regamey 2012b). Rumours about women-snipers and mercenaries may be "true" for soldiers as far as they suggest that Russia is under treacherous attacks from the outside (see the chapter about Baltic mercenaries as enemies) and because they allow for an expression of fear for their virility (see the chapter about threatened masculinities).

Another approach to the question of truth is to consider that legends may be true or false, but that they are legends (or rumours) since they "lack any systematic means of authentication" (Baky 1994) or they "lack secure standards of evidence" (Fine \& Ellis 2010: 4). But this approach is challenged by the fact that legends do not only "make a claim about the truth of an event" (Oring 2008: 128) - they also use a specific rhetoric and different tropes to support these claims, and mobilise a "rhetoric of truth" (Oring 2008).

Indeed, different means are employed by those who report legends to suggest that these stories could be validated by "secured standards of evidence": reference to experts' opinion (physicians, the military), presentation of physical clues and logical proofs, etc. But even a perfunctory scrutiny allows us to see the 
faults in this rhetoric: hasty or over-generalisations, confusion between effects and causes, faulty syllogisms, inversed logical connections, etc.

By way of example, we can quote an interview with the separatist fighter who claims to have captured the Ukrainian military pilot Nadezhda Savchenko in June 2014. More than one year after her capture, he tries to convince the journalist that she was a sniper, by using different "means of authentication":

- But is Savchenko really a sniper?

- Of course. Do you think a helicopter aviator would get the call-sign 'Bullet'? No! Impossible. She could be.... whatever, but not 'Bullet'. Believe my combat experience, this call sign is chosen by sharpshooters or by snipers... - Are you sure? Did you question her, or what?

- I am not sure, I know. Why do I insist on that? Because when I went away with her, I took her personal belongings. A grey backpack with pink flowers, which contained a red civilian dress, black $V$-string panties and white sandals. Why should a helicopter pilot with the call-sign 'Bullet' be on the front line with civilian clothes? So as to be able, at the right time, to change clothes and go away. (Azar 2016)

As we will see further on, war legends may circulate among soldiers or be picked up by official propaganda - but in both cases they can still be "defined as a narrative performance that invokes a rhetoric of truth" (Oring 2008: 159).

\section{SOLDIERS' RUMOURS AND OFFICIAL PROPAGANDA}

In August 1914, rumours about Belgian "Francs-tireurs", armed civilians who treacherously attacked German soldiers, prompted German soldiers to commit violence against the civilian population in retaliation (Horne \& Kramer 2001). Fernand van Langenhove, who first investigated this rumour, suggested that it was born on the frontline and then spread to the rear: "Those legends that were told in letters from the front, were reprinted and multiplied by the press under control, they passed then in books, in the chronicles of war, in short stories, in popular literature and theatre" (Langenhove 1916: 235). They finally gained an official consecration in political statements. Relying on his experience on the front during the First World War, French historian Marc Bloch suggested also that rumours were mainly born among soldiers, and that they circulated via word-of-mouth between the front and the rear (Bloch 1999 [1921]).

The fact that these rumours come "from below" suggest that war legends are not just a synonym for propaganda or disinformation "from above". Indeed, 
"falsehood" can take "several different sorts of disguises", from the "deliberate official lie" and the "deliberate forgery" to "the general obsession, started by rumour and magnified by repetition and elaborated by hysteria, which at last gains general acceptance" (Ponsonby 1928). But whatever their origins, rumours are used by officials and state media to stigmatise the enemy and thus can be first investigated as a part of official propaganda.

The legend of women-snipers in Chechnya seems to have circulated following a logic quite similar to that described by Van Langehove. Rumours about the presence of "White Stockings", women mercenaries from the Baltic countries, circulated among Russian troops in Chechnya during the first war (1994-1996). By accrediting these rumours, military and political authorities spread them further and gave them an echo in the whole Russian society. Relying on official statements, the Russian media helped to spread these rumours, either by providing deliberately false information or by twisting the reality, using the slightest sign as "proof", publishing headlines disconnected with the article content, etc.

On January 18, 1995, during the battle for Grozny, an article in the daily Kommersant quoted a document from the "sources close to the border guard" to assert that several foreign mercenaries were fighting in Chechnya. According to this document, "the presence of mercenaries from the Baltic countries is substantiated by precise facts. In Grozny central districts, women-snipers, members of the organisation 'White Stocking' have been spotted" (Romashov 1995). On January 24, 1995, Russian army newspaper Krasnaya Zvezda as well as several TV channels reported that a platoon of "women-snipers from Estonia and other Baltic countries" was based in a flat at 4 Malgobek Street in Grozny. According to Russian journalist V. Voronov, it was a deliberate forgery: the media picked out a flat that was in fact the apartment of three women journalists. ${ }^{11}$

When the Second Chechen War began in August 1999, the same phenomenon could be observed. Chechen warlord Shamil Bassaev conducted a military raid in the neighbouring Dagestan Republic to support Islamic villages. On October 2, 1999, Russian newspaper Nezavisimaya Gazeta reported in an article titled "The White Tights fought in Dagestan" that three foreign sniper women fought alongside the Wahhabis and that according to the Ministry of Interior one was "a mercenary from the Baltic States" (Dargo 1999). On February 17, 2000, Russian spokesman Sergey Yastrzhembsky declared that "federal forces possess irrefutable evidence that women-snipers are fighting on the side of the militants". ${ }^{12}$ Yet, none of the information he gave on the three women showed that they were women fighters, let alone sharpshooters.

On February 14, 2000, Pervyi Kanal (First Channel) informed its audience about the arrest of two women who had been identified by the special services 
as snipers. One of the women was shown on TV: she was blindfolded, and the journalist zoomed in on her hands and on her face, while someone (supposedly a member of military intelligence) explained why she undoubtedly was a sniper:

The fact that the finger is bent and callous is the first sign. The second one: the light facial hair on the left side of the face can be quite clearly seen - while on the right side of the face the hair is rubbed out. ${ }^{13}$

This is not the only case where such flimsy proofs have been used. Another article about a woman arrested while leaving Grozny in 2000 specified that "investigators believe that wearing only one earring is an indirect indication that the woman is a sniper. It is more convenient to shoot. The second distinguishing feature is a bruise on the shoulder, made by the rifle butt". ${ }^{14}$ The parallel with the Amazons, who were said to cut one breast to bend their bows more easily, is obvious here.

There was a similar construction of the figure of the enemy sniper, with minor signs transformed into "evidence", in the case of the Ukrainian Deputy Minister of Youth and Sports, Olena Pidrushna (Elena Pidgrushnaia in Russian). On June 1, 2014, Konstantin Dolgov, one of the leaders of the Novorossiya Popular Front, accused her on the Russia-1 TV channel of killing civilians in the eastern Ukrainian town of Slavyansk. His main argument was that "her husband is a member of the ultranationalist fascist party in the Ukraine" and these kinds of pseudo-logical links (she is married to a nationalist so she is a nationalist; nationalists are fascists so she is a killer) - were also the main arguments used by such newspapers as the official Rossiyskaya Gazeta, when they wrote:

In view of her biography, Pidgrushnaia, native from Ternopol, could well have been found to be on the Karachun with a rifle in his hands. The thing is that Elena married a year ago a very active leader of the Ukrainian Nazis, Aleksey Kaida. [...] Besides, Pidgrushnaia herself has repeatedly demonstrated her support for Ukrainian 'national idea' (emphasis added). (Likhomanov 2014)

The circulation of this kind of so-called "information" is certainly accelerated and aggravated by some faults of the media themselves: systematic publication of official information, no cross-checking, sensational headlines that have very little to do with the content of the article, etc. In the case of the current "information war" in Ukraine, these kinds of practices can be found on both sides of the conflict. ${ }^{15}$

On the Ukrainian side, in January 2015, newspaper Ukrainska Pravda reported that "special forces of the SBU [Security Service of Ukraine] arrested 
a young woman who operated as a sniper and killed at least ten Ukrainian soldiers". ${ }^{16}$ Nevertheless, the only "proofs" provided both by the SBU and Ukrainska Pravda were in fact photographs of the young girl posing with weapons, and snapshots from her personal page on Vkontakte and in other social media. According to the Euromaidan Press release, "By her own admission, Anastasia stated that she has used several weapons, the automatic rifle RPK74 (Kalashnikov) and the anti-tank weapon, RPG-7"17 (emphasis added). This "avowal" is in fact an answer to an anonymous question on Sprashivai.ru (http://sprashivai.ru), an internet website dedicated to anonymous contacts and discussions online, the largest one in Russia and the Commonwealth of Independent States (CIS).

Articles from one online edition are usually copy-pasted from one website to another without further verification, and social media permit a faster circulation of rumours and legends through numerous reposting and sharing, and constitute virtual communities where state borders are blurred.

\section{LEGEND BETWEEN POPULAR CULTURE AND MILITARY EXPERIENCE}

However, if this kind of information circulates so easily, it is also because it is considered as a plausible piece of news that resonates with existing representations. We must indeed, at this stage, mention the role of culture in spreading the legend of women-snipers.

They are mentioned first of all in soldiers' songs, such as "Snaipersha" (Female Sniper) by Serhzant Agapov, ${ }^{18}$ about a 16-year-old sniper in the ruins of Grozny, or "Devushka-sniper" (Girl-sniper)19 by Igor Zhdamirov, a Russian Afghan veteran who came to eastern Ukraine to support the separatists. These songs are sung or listened to among soldiers, but they also find a larger audience through the Internet.

Some veterans also took to writing, and there are numerous novels on womensnipers on Artofwar.ru (http://artofwar.ru) or other websites. ${ }^{20}$ The figure of the Baltic sniper is also at the core of some popular war novels: Viper: The White Tights by Ivan Streltsov ${ }^{21}$ or The End of the Last Hour by successful detective writer Friedrich Neznansky, which features an ultranationalist and paramilitary association in Estonia, where women learn to shoot and fight. ${ }^{22}$ Thousands of copies of these novels were published, but the largest diffusion of the legendary figure of the Baltic mercenaries is certainly due to films, which are shown on Russian TV, broadcasted all over the former Soviet Union, distributed through DVD copies, and once again shared on social media (especially Vkontakte). 
Chistilishche (Purgatory, 1997) by Alexander Nevzorov reached $34 \%$ of the Moscow audience when it was shown on TV on March 23, 1998. ${ }^{23}$ It shows sadistic Baltic female sharpshooters fighting along with barbarous Afghan and African mercenaries against courageous but helpless young Russian soldiers. In Muzhskaia rabota (Men's work, 2001) by Tigran Keosaian, two Baltic women mercenaries are hired to fire upon an OSCE convoy. Proryv (Breakthrough, 2006) by Vitaly Lukin shows a blond sharpshooter fighting against Russians under the command of an Islamic mercenary.

In Blokpost (Checkpoint, 1999), A. Rogozhkin, a film director best known in Russia for his comedy films, depicts the life of soldiers based somewhere in the North Caucasus. In spite of the danger (they are threatened by a sniper) they try to enjoy life; they also use the sexual services of a simple-minded woman who her younger sister sells to the soldiers. In the end the viewer discovers that this younger sister is precisely the sniper, and understands why she always insisted on being paid in cartridges. The film combines two different story lines, on which the legend of women-snipers is usually built: 1 - soldiers are threatened by a sniper, they finally discover that this sniper is a woman (and take revenge); 2 - soldiers develop a relationship with a woman from a nearby village before they find out that she is a sniper.

In their studies on Belgian legends about "Francs-tireurs" during the First World War, Horne and Kramer (2001) show the crucial role of the cultural background in shaping the legend (memories of the previous war with France, literature, media). But they also insist on reconstructing soldiers' subjective experience, and show that the grip of the legend is stronger when the cultural background combines with a specific situation in the field. The "Franc-tireur" legend was also convincing for German soldiers in 1914 because they were confronted with new weapons, and could not determine where the shooting came from.

In post-Soviet conflicts, the woman-sniper seems also to crystallize the main fears of the soldiers on the ground. Post-Soviet conflicts are often mountain or urban guerrilla war, where soldiers hold checkpoints and are afraid of being targeted by a sniper; the problem of friendly fire, common to all armies in the word, certainly reinforces the fear of an enemy who seems to shoot out of nowhere.

In the cases when soldiers occupy part of their enemies' territory, the womansniper also embodies the hostile part of the civilian population, which the soldiers should distrust: the part that secretly supports the enemy and may, at any time, turn against the occupying army. The legend appears here as a form of popular military knowledge, of "military lore" (Barden \& Provo 1995): by repeating the legend, soldiers also exchange pieces of advice on how to behave in the field, what to be wary of. It contributes also to creating a figure of the enemy among the local population, the treacherous pacific/civilian (mirnaia) girl. 
It is indeed significant that the legend evolves with the changes in military warfare and adapts to specific situations. In Donbass, for example, soldiers are frequently under heavy artillery fire, and there is a widespread suspicion against navodchiki (spotters), civilians who are accused of helping the enemy by correcting their artillery fire. This fear leads to the creation of a new mythic figure, the sniper-spotter. Nadezhda Savchenko was thus presented on the Russian NTV channel as a "woman-sniper who adjusted fire during the combats". ${ }^{24}$ And the soldiers of the Ukrainian Donbass Battalion also mix the two notions:

These girls, they look like pacific civilians but in reality they select a point, and half of them adjust fire, and after that they work with sniper complex against our soldiers. ${ }^{25}$

Even if the meaning of a "sniper complex" is not very clear, the last quote reminds us of the way a legend can evolve: based on a long-existing storyline, the rumour takes new forms depending on the realities on the ground, and these new forms, in turn, may find some representations in popular culture.

\section{BALTIC MERCENARIES AS ENEMIES: ANTIFASCISM, ANTITERRORISM, ANTI-AMERICANISM}

As we have seen, legendary women-snipers in the post-Soviet space are often embodied in the figure of "White Tights" or "White Stockings", the Baltic mercenaries who fight against Russian or pro-Russian forces. These former biathlonists appear in films and popular novels, but are also regularly mentioned in the media and/or by politicians. For example, the official newspaper of the Russian army, Krasnaya Zvezda, is adamant that "during the first Chechen campaign, [Bassaev] created a special platoon, 'the White Tights', comprising mainly women-snipers from the Baltic states. Every day they were paid 1,000 US dollars, and 1,500 dollars for each Russian soldier they killed" (Astashkin 2003).

The figure of these Baltic snipers appeared regularly in Russia in the first decade of the twenty-first century. After the hostage-taking in a school in Beslan (North Ossetia) in September 2004, the website Lenta.ru stated that "the terrorists in Beslan were covered by Baltic snipers". Lenta.ru relied on the declaration of a witness who saw "a very tall man with a sniper rifle" who talked with a "Baltic accent", and a "young blond woman who held a rifle with a telescopic sight". ${ }^{26}$ 
Baltic mercenaries were also allegedly seen in South Ossetia in August 2008. The nationalist leader Vladimir Zhirinovsky, well known for his provocative declarations, thus stated in a radio interview:

Ukrainian nationalists went there, without having any right to do it. Baltic snipers went there. Perhaps we should also talk kindly with the Balts?! How many Russian soldiers did they kill in Chechnya! [...] The same with Ukraine: we have to take tough measures. ${ }^{27}$

This link between Baltic snipers and Ukrainian nationalists is not new. In My War, published in 2001, Russian general Gennady Troshev wrote about Ukrainian mercenaries from the nationalist group UNA-UNSO (Ukrainian National Assembly - Ukrainian People's Self-Defence) and noted that there were also "girl snipers from Poltava and Nikolaev" (Troshev 2001) together with Chechen fighters.

This figure of the female Baltic mercenary allows to embody the enemy and, in turn, to characterize the struggle of Russian and pro-Russian forces around two key narratives: the continuation of the struggle led by the USSR against fascism during the Second World War, and the fight against a powerful and globalized external enemy, Islamic terrorism and/or American expansionism.

The name "White Tights" first reminds of the white camouflage suits worn by Finnish soldiers, called "Belofiny" (White Finns) by the Soviets during the 1939-1940 Winter War. The memory of Finnish kukushki (cuckoos), snipers who moved on skis, hid in the forests, and inflicted heavy losses on Soviet soldiers, is still so present that the term is used to describe any enemy sniper. The nickname "White Tights" or "White Stockings" probably derives from the snipers' winter camouflage uniform. Indeed, protection suits are called " $z a$ shitnye chulki" (protective stockings), and a "belyi chulok" (white stocking) is also a white knitted tube used by snipers to hide the dark parts of their rifle in winter (Rasskazov 2001). The expression "belyi chulok" is used together with "belye kolgotki" as a nickname for women sniper mercenaries. ${ }^{28}$ But while the term "chulok" has several meanings, including the stockings worn by women, its synonym, kolgotki, is used only for women underwear. Thus, the more frequent use of "belye kolgotki" insists on the feminine dimension and suggest that those who wear them are women.

Secondly, Baltic mercenaries are also presented as the descendants of the "Forest Brothers" who fought against Soviet soldiers, as the granddaughters of Baltic fascists of the Second World War. In dominant representations in Russia, the Baltic countries and Ukraine are linked by a common hatred towards Russia, a common fascist past, and common historical collaboration with the Nazis. The 
memory of the Second World War is indeed crucial in Russian official discourse related to these countries: the scandal around the removal of a monument to the Soviet soldier in Estonia (2007), and the official denunciation of the parades of the former Latvian SS in Riga. In 2014 Moscow described the new Ukrainian government as fascist, while pro-Russian separatist fighters rallied around the St. George's ribbon, which in the recent years has become the symbol of the Russian victory in the Second World War.

Finally, the fact that there are mercenaries suggests that substantial sums of money are at stake, and that the enemies benefit from the support of an international-scale power, the Islamic terrorists or the United States.

During the second war in Chechnya, the alleged presence of mercenaries was supposed to prove that Russia was fighting against international Islamic terrorism. Sergei Filatov, head of the presidential administration under Yeltsin in the $1990 \mathrm{~s}$, explained that "there were, at one time, Ukrainian nationalists and female snipers from the Baltic states. Then the link was made with the Afghan factions and bin Laden". ${ }^{29}$

More recently, in Ukraine, the Americans and NATO have been pointed out. While NATO conducts joint exercises with the Ukrainian army, and the Americans and the British send military advisers, Moscow denounces the presence of US mercenaries fighting directly in eastern Ukraine.$^{30}$ From speculations about the presence of "private security companies", such as Blackwater, discussions shift to the presence of black Afro-American mercenaries. ${ }^{31}$ "And also, they say, Niggers have been seen," confessed a separatist militant to a Russian volunteer in the Donetsk People's Republic (DPR): “They are mercenaries fighting here... from the United States, and up there they would sell their own mother for money" (Maksakov 2014).

And, once again, when black mercenaries are discussed, women-snipers are not far away. According to the Secretary of the Security Council of the DPR, Aleksandr Khodakovsky, no mercenary has been captured yet because they usually serve in the rear and fire from a long distance. "But they did kill, yes! Including the Baltic women-snipers. They have been active on that side from the beginning of the conflict." 32

These accusations against the Americans and NATO date back to the Maidan manifestation in Kiev. Snipers were said to be responsible for the killings of February 2014, and since the beginning of the demonstrations rumours circulated among President Yanukovych's supporters about the presence of NATO or American snipers on the protesters' side. ${ }^{33}$ Moreover, there were suppositions that the "snipers who allegedly shot at 'people in the street' during the February 19-20 bloodshed in Kiev had also shot at the police" (Denber 2014) - to provoke the bloodshed and make the two parties in conflict act against each other. 
This kind of rumour is not new: in October 1993, when President Yeltsin had soldiers fire on the Russian Parliament, entrenched in the "White House", some White House defenders said to have seen snipers on the roof of the American Embassy. A witness also talked about a woman carrying a rifle with a telescopic sight on the upper floors of a building near the White House - which led the journalists to conclude that the rumours about the presence of the "White Tights", who already fought in Abkhazia and Transnistria, were not unfounded. ${ }^{34}$

Dmitry Rogozin, former representative of Russia to NATO and Deputy Prime Minister since 2011, suggests in his memoirs that a firing post could not have been placed on the roof of the American embassy without the US ambassador's knowing about it. Thus, he suggests that Americans are the "third force" who "covertly prompted the massacres, and caused an escalation between the two parties" (Rogozin 2010).

The same idea is voiced by a fighter from the pro-Russian separatist Vostok brigade, when he talks about the Ukrainian Special Forces with whom they were fighting:

Those were good guys there. It was the Kirovograd Special Forces. They are great soldiers [...] honour to them. But then mercenaries intervened. They fired against the guys of the Kirovograd Special Forces and they fired at us, Vostok. It was a repetition of the Kiev scenario, you see. That is, they shot at the Special Forces and shot at us, so that we would shoot at each other. ${ }^{35}$

\section{WOMEN IN THE ARMED FORCES: AN ADDITIONAL TRIGGER TO THE LEGEND}

To what extent may the legend of women-snipers be related to the presence of women in the military, and to the fact that some women have really served as snipers in the Soviet army?

As for contemporary Ukraine, there are a growing number of women in the armed forces and women are becoming more vocal about their right to serve together with men. ${ }^{36}$ No wonder then that Ukrainian media report about women-snipers in the army; yet, there seems to be a growing confusion, at least in media discourse, between the "shooter" and "sniper". A sniper is indeed a highly specialized military professional, a long-trained sharpshooter with specific camouflage skills, whose rifle is usually fitted with a telescopic sight, while the women who are presented as snipers have in fact a very short military training. 
We could mention in this context, for example, a TSN News report about a girl-sniper from the Donbass battalion, a 23-year-old hairdresser-visagiste who became a sniper.$^{37}$ However, we learn from the same TSN report that before the war she had never touched a weapon - which makes it very unlikely that she became a sniper in a few weeks. Similarly, even if we lack sociological studies on women in the armed groups of the Donetsk and Lugansk Popular Republics (DNR/LNR), we can assume that very few of them have actually been trained to use weapons - not to mention being elite shooters. Tatiana Demchenko, the leader of the DNR women battalion, admitted, for example, that "the vast majority of women had never had a weapon in their hands before joining the militia" (Melnikov 2014).

The word "sniper" thus seems to be increasingly used as a synonym for "shooter", or even for "rifleman". This confusion may come from the double meaning of the Russian world strelok. Strelok can indeed be translated simply as "a soldier with a rifle", strelkovaia chast' being an infantry unit. At the same time, in the 1930 s, the best shooters trained by the Soviet paramilitary organisation OSOAVIAKhIM (Union of Societies of Assistance to Defence and Aviation-Chemical Construction of the USSR) were decorated with the medal of Voroshilovskii strelok (named after the People's Commissar for Defence, Klim Voroshilov) - in this case, strelok was indeed a synonym for "sharpshooter".

There were men and also women among the snipers trained in the Soviet Union in the 1930s, some of whom fought during the Second World War. The most famous is undoubtedly Lyudmila Pavlichenko, who took part in the battles of Odessa and Sebastopol in 1941-1942 and was credited with 309 kills, the highest score for a woman-sniper. She is still a well-known figure nowadays, especially after the release of a Russian-Ukrainian film Nezlamna (Indestructible), based on her biography, in March 2015. In Ukraine, references to Pavlichenko are made by both sides of the conflict; she is compared to the Ukrainian pilot Nadia Savchenko, ${ }^{38}$ while her photograph circulates in pro-separatist social networks with the caption: "Rambo? No, never heard. Lyudmila Pavlichenko, 309 dead fascists". ${ }^{39}$

While 800,000 women served in the Red Army in different capacities (nurses, auxiliaries, etc.), in 1943 a Central Women Snipers School was established in Moscow to train women for the front. These circumstances, as well as Soviet propaganda around women snipers, probably fuelled the rumours inside the German army at that time. There is, in fact, a huge gap between the real number of women-snipers and the pervasiveness of this representation among Wehrmacht soldiers: no more than 2000 women were trained at the Central Women Sniper School during the war. But the rumour also relied on other factors: the imagery of cruel and depraved Red women with guns, the "Flintenweib" (Freytag 2002), 
the fact that even nurses and orderlies carried guns, etc. Here, the legend was certainly fuelled by the vision of Red Army female soldiers, but this representation, distorted and magnified, found a fertile ground in an imagery already formed by pre-existing rumours and fiction (Theweleit 1987).

But what about the post-Soviet imagery of women-snipers? To what extent can it be influenced by the historical experience of Soviet women-snipers? My hypothesis is that the legend is based on an inversion: the features and characteristics that are specific to one's own army are attributed to that of the enemy. This inversion is possible in the post-Soviet space, because the enemy is perceived as very close and very similar.

Indeed, in most of the wars of the post-Soviet space, the enemy was once "one of us": it was very often a former neighbour, who grew up during the Soviet period. In "Devushka-sniper", Igor Zhdamirov sings about a soldier who leaves "to fight against a former brother / he's got the same automatic rifle / and swears in Russian just like us". This similarity allows for transposing the figure of the woman-sniper from one's own past and practices to that of the enemy. This transfer can be done only if the opposing society is perceived as sufficiently similar: there are, to my knowledge, no rumours about Afghan women-snipers, Afghan society being perceived as ultra-traditional. ${ }^{40}$

Thus, it is possible to imagine women-snipers in the opposing army because there were female snipers in one's own historical experience. The knowledge of this historical experience relies mainly on Soviet official memories and Soviet/ Russian films. So the imagery of women-snipers is in fact built on a process of permanent swinging to and from historical reality to fiction.

The vocabulary used by fictional contemporary women-snipers imitates the expressions of the Second World War, such as "going on a hunt" - meaning lying in wait. ${ }^{41}$ More generally, the practices of the fictional "White Stockings" reflect, as in a distorted mirror, the exploits of Soviet snipers: some practices of Soviet sniper women are distorted and ascribed to their fictitious homologues, and, in turn, these fictional practices are imputed to the Soviet women-snipers.

The White Tights are, for example, accused of marking their number of kills on their rifle butts, like the woman "with an SVD sniper rifle, produced in Russia, the butt of which had about a dozen notches. This sniper, who had an Estonian passport, admitted that this was her way of counting the number of soldiers she had killed" (Ianchenkov 2004). This alleged practice can be traced back to the Second World War. The number of enemies a sniper had eliminated was indeed precisely calculated, and the most successful snipers did receive a personal rifle. The account was officially kept in the military booklet of the "sniper, exterminator of fascists", but it could be also kept by snipers themselves. Thus, the Soviet documentary film Chernomortsy (1942), dedicated to 
Sebastopol defenders, shows a sniper "keeping his own account" by making marks with a knife on the root of a tree, in his trench. ${ }^{42}$

Lyudmila Pavlichenko also features in this film, and the operator insisted on filming her among the blossoms of a tree in flower, as a tribute to her femininity (Begunova 2014: 108-109). In another context, namely during a trip to the United States in 1942, to appeal to the American people, the representation of her femininity focused on her make-up and especially on the nail polish that decorated her "trigger finger" ${ }^{43}$ In turn, this focus on nails as a symbol of femininity is used and reverted in the representations of contemporary womensnipers:

On June 24, in Bendery a sniper was arrested, a mercenary from Lithuania, on whose account there were 33 victims. She used to make the notches on the butt of her rifle... with a nail file. (Medvedev n.d.)

Keeping count of their victims with cruel pleasure, women-snipers are also said to take fun in killing their victims slowly, like in Nevzorov's Chistilishche, where they gradually wound and mutilate soldiers before killing them. In Fatima, Russian writer Scherbakov pictures a sniper who gets sexually aroused when killing:

She made fun of her victims, playing with them. She drove alternately a bullet into each limb of the soldiers, and when they could no longer move or crawl, the fifth shot put an end to their life. (Shcherbakov n.d.)

A virtually identical scene can be found in S. Mokritskiy's recent film on L. Pavlichenko, in which, to impress her new partner, she plays with a German soldier and wounds him twice before finally killing him. ${ }^{44}$ So we can see how the legend finally influences the current representations of the Soviet women-snipers.

\section{THREATENED MASCULINITIES}

In a 2001 article about snipers in Chechnya, a Russian journalist quoted the alleged threats of a woman-sniper Masha to her future victims:

I'm going to kill you slowly, because I love it. I will first shoot you in the leg, I promise to aim at the kneecap. Then the hand. Then your balls. (Maetnaia 2001)

As an additional form of "refinement", the White Tights are said to take specific pleasure in shooting soldiers in their reproductive organs. On March 31, 2001, a Russian information website indicated that a Tajik woman-sniper was 
captured and killed after she advised soldiers by radio to "protect their private parts". ${ }^{45}$ This rumour is still alive, and thirteen years later, an eastern Ukrainian separatist fighter declares after the combats around Grozny Airport:

Snipers were chicks. We liquidated two of them, one by sniper fire, the other with a RPO, a flame-thrower. By the way, one of our fighters, he's a 300th [injured], he was shot in the inner part of the thigh, she aimed at his groin. ${ }^{46}$

More often than not, there is a second part to this legend: in Chechnya, it was said among Russian servicemen that women-snipers who castrated soldiers must be raped in retaliation and "exploded" by putting a gun or a grenade in their vagina. There were numerous stories about a Baltic biathlonist Milita Trankautene, who "cynically castrated young Russian officers with her precise shots", and who was "dropped from a helicopter by wounded paratroopers with a grenade in the vagina" (Maetnaia 2001). Aleksandr Krylov, who fought as a volunteer in Transnistria, admits that he had heard this story several times:

Well, the story of how the 'bitch-sniper' with a grenade shoved between the legs is thrown out of the windows of a multi-storey building - I have heard it from almost all participants in the so-called 'local conflicts', which took place during the past ten years on the territory of Russia, the former Soviet Union, and Eastern Europe. Well, of course with variations - concerning mainly the countries and the cities where, supposedly, these events took place, as well as the number of floors of the building where the execution was carried out. (Krylov 1999)

There seem to be several layers of interpretations to this aspect of the legend. First, we should remember the specific erotic connotations of a woman with a gun. In army folklore, the gun is very often compared with the soldier's girlfriend, like in this army proverb: "A rifle loves to be cuddled, cleaned, and lubricated" (Vintovka liubit lasku, chistku i smazku). The slang term "dvustvolka" refers not only to a double barrel rifle, but also to a woman who has sexual relations with two men at a time, a prostitute or simply a woman. ${ }^{47}$ But even more than sexual desire, the legend seems to refer to the castration complex, which Marie Bonaparte mentions in her analysis of war myths (Bonaparte 1946: 106-107). In this regard, two research directions seem particularly fruitful to explain the legend and its post-Soviet specificities: the accommodation of traditional themes and the fear of losing one's virility.

The theme of the dangerous woman who deprives the man of his virility can be traced back to the traditional vagina dentata folktales - a recurring motif in the mythologies of the world. The vagina that imprisons a man, severs his 
penis, and swallows it, is also the symbol of annihilation, of nothingness, as suggested by this Russian riddle: "What is not and will never be, and if it did exist nothing would exist? - A pussy with teeth". The same motive can be found in the Vietnam War stories about Vietnamese prostitutes who put Coke bottles in their vagina to emasculate American GIs (Barden \& Provo 1995). It appeared then as an expression of the fear of venereal diseases, and we can also mention here the American Army posters of the 1940s, which warned soldiers against the "juke joint sniper: syphilis and gonorrhoea" (Keneally 2011).

Traditional themes can also be seen in the punishment of the woman-sniper. The stories in which the women-snipers are pulverized and scattered in the wind evoke Russian traditional tales where the witch is torn to pieces, like in the White Duck:

The birds came flying up, and they pecked the flesh; the winds swept up, and they bore off the bones. And nothing was left of the wicked witch, neither trace nor word nor memory. ${ }^{48}$

When a Russian soldier says that he saw "how a woman-sniper was attached to an armoured vehicle and hauled on the road till all her flesh was torn", ${ }^{49}$ his story resembles very closely the end of the folktale "Sister Alyonushka and Brother Ivanushka", when "the wicked witch was tied to a horse's tail and the horse turned loose in an open field". The parallel between witches and womensnipers is even explicit in the story of a veteran of the 1994-1996 Chechen War, who recalls the execution of a Latvian sniper: "First, like a witch, she was nailed to the ground with stakes. Then she was crushed by an armoured car" (Belibentsev 2006).

The second theme in the story of the castrating woman-sniper and her punishment is the fear of losing one's manliness. This virility angst is not unique to post-Soviet fighters: everywhere "soldiers traumatised by war suffer from erection problems or premature ejaculation" (Le Naour 2007: 74). In addition, soldiers in the field are afraid of adultery, lest the women they leave for long periods may deceive them. Women-snipers also embody this fear of women's treason, which explains why in certain articles ${ }^{50}$ or songs they are Russian: for instance, in Igor Zhdamirov's song "Devushka-sniper" a young man dies from a bullet of his former girlfriend.

This fear of "not being a man any more" after the war is further aggravated by the post-Soviet context. Indeed, in many post-Soviet countries, the economic crisis of the 1990s did hit hard on men, who could no longer play their role of a "breadwinner" (Hohman 2015). The army, in representations still associated with manhood and courage, was not in a better condition: antiquated weaponry, dilapidated housing, low wages, and belated pay (Sieca-Kozlowski 2008). 


\section{CONCLUSION}

What can ultimately be the effects of this legend on the war field in various post-Soviet war contexts? The question deserves to be asked, since we have seen that the mythic figure of the "woman-sniper" sheds suspicion on female civilians in the conflict zone; it puts also servicewomen at a specific risk of being subjected to retaliation when captured.

There is undoubtedly a link between representation and violence (Horne \& Kramer 2001; Semelin 2002), even if other factors may be more central in explaining extreme violence (sudden de-socialisation and resocialisation in a violent group, incentives from the state or the media, sense of impunity, "moral holiday" or "forward panic" (Collins 2009; etc.). Moreover, the issue of sexual violence is particularly acute, since, as we have seen above, one of the punishments administered on the woman-sniper is rape.

In Chechnya, the legend was used as a justification for violence in the socalled Budanov case. Colonel Budanov, who abducted, raped, and killed a young woman in March 2000, built his entire defence in court on the allegation that she was a sniper, that she had killed his men, and that he had lost control of himself while questioning her (Regamey 2008, 2012a). But while the legend is used as a justification a posteriori, can we assume that it also plays a role a priori, in sparking or triggering violence?

In Chechnya, women were arrested on suspicion of being snipers, and became the inmates of a detention system where cases of rape and ill-treatment were widespread. In Ukraine, a former fighter of the Ukrainian Aidar battalion mentioned in an interview, among other cases of violence he witnessed at the front, the rape of women prisoners:

I once heard myself how one of the prisoners was raped. [...] Afterwards, I asked who this woman was. 'Oh, it's a separatist sniper.' - 'And how do we know? Did we take her with a weapon in hand?' - 'No, we found a balaclava among her things.' And so this woman, just because she had a balaclava, was taken to prison, where she was raped.(Chapai 2015)

On the separatist side, in the Donetsk People's Republic, the legend seems to have the same tragic consequences:

A volunteer from Kyiv, whose name cannot be made public, was working for an association distributing humanitarian aid in conflict affected areas. She was kidnapped on 12 June 2015 [...] by the DPR's MGB (Ministry of State Security) and accused of being a sniper belonging to the Pravyi Sektor (Extreme right pro-Ukrainian group). She was beaten and tortured even 
after MGB found that she is pregnant. She spent approximately 2 months in captivity and was released in August 2015. (FIDH/CCL 2015: 27)

Faced with these facts, the question of the responsibility of the researcher arises. To my opinion, the consequences of the legend of women-snipers require not only studying the multiple narratives and their "rhetoric of truth", but also showing its fallacy and "deconstructing" it whenever and wherever possible.

\section{NOTES}

1 Feik: ukrainskaia biatlonistka Elena Pidgrushnaia ubivaet detei v Slavianske (Fake: Ukrainian biathlonist Elena Pidgrushnaia is killing children in Slaviansk). Stopfake. org, June 2, 2014. Available at http://www.stopfake.org/fejk-ukrainskaya-biatlonistkaelena-pidgrushnaya-ubivaet-detej-v-slavyanske/, last accessed on May 31, 2017.

2 Ukrainskuiu olimpiiskuiu chempionku v Rossii schitaiut snaiperom ATO (In Russia, Ukrainian Olympic champion thought to be a sniper in the anti-terrorist operation). Obozrevatel', June 1, 2014. Available at http://sport.obozrevatel.com/sport/71963ukrainskuyu-olimpijskuyu-chempionku-v-rossii-schitayut-snajperom-ato.htm, last accessed on May 31, 2017.

3 Interview with Oleg Panfilov on Radio Svoboda, April 29, 2009. Transcript available at http://www.svobodanews.ru/content/transcript/1618827.html, last accessed on May 31, 2017.

4 Interview with General Troshev in Rossiiskaia Gazeta, March 28, 2001 (http://www. rg.ru/interview/543.shtm, no longer available).

5 Zhenshchina-snaiper rasskazala o napadenii na rossiiskikh zhurnalistov (Womansniper told about the attack on Russian journalists). NTV.ru, June 17, 2014. Available at http://www.ntv.ru/video/870600/, last accessed on May 31, 2017.

6 Na gore Karachun sily ATO plenili trekh zhenshchin-snaiperov (On Karachun Hill anti-terrorist troops captured three women-snipers). July 5, 2014. Available at http:// www.0629.com.ua/news/569786. Vo vremia boia na Karachune tri zhenshchinysnaipera sdalis'v plen silam ATO (During the battle on Karachun, three women-snipers surrendered to anti-terrorist forces). July 5, 2014. Available at http://obozrevatel.com/ politics/62140-vo-vremya-boya-na-karachune-tri-zhenschinyi-snajpera-sdalis-v-plensilam-ato.htm, both last accessed on May 31, 2017.

7 V Komsomol'skom sdalas' v plen zhenshchina-snaiper. Lenta.ru, March 24, 2000. Available at http://lenta.ru/vojna/2000/03/24/komsomolskoe/, last accessed on May $31,2017$.

8 The war during the period of 1999-2009. The campaign ended the de facto independence of the Chechen Republic of Ichkeria and restored Russian federal control over the territory (see https://en.wikipedia.org/wiki/Second_Chechen_War, last accessed on July 13, 2017). 
9 Shturmom namagalisia vziati boioviki s'ogodni selishche Shirokine (Today insurgents tried to seize Shirokine village). TSN News, March 9, 2015. Available at http://tsn.ua/ video/video-novini/shturmom-namagalisya-vzyati-boyoviki-sogodni-selische-shirokine. html, last accessed on May 31, 2017.

${ }^{10}$ One Serbian PKK sniper killed, another captured in Turkey's southeast. Hurriyet Daily News, February 2, 2016. Available at http://www.hurriyetdailynews.com/oneserbian-pkk-sniper-killed-another-captured-in-turkeys-southeast.aspx?PageID=238\& NID=94639\&NewsCatID=509, last accessed on May 31, 2017.

${ }^{11}$ See http://www.evartist.narod.ru/text1/81.htm\#\%D0\%B7_17, last accessed on July 10, 2017.

${ }^{12} \mathrm{~V}$ Chechne arestovany tri zhenshchiny-snaipera (Three female snipers arrested in Chechenia). Lenta.ru, February 17, 2000. Available at http://lenta.ru/vojna/2000/02/17/ sniper/, last accessed on June 1, 2017.

${ }^{13}$ Dlia zhitelei Groznogo zakryt svobodnyi prokhod v gorod. Na vykhode iz goroda zaderzhana zhenshchina-snaiper (Free access to Grozny is closed to its inhabitants. On the town's edge a woman-sniper was arrested). Pervyi Kanal, February 14, 2000. Available at http://www.1tv.ru/news/2000-02-14/, last accessed on June 1, 2017.

${ }^{14}$ Snaipersha Anna: Moloduiu moskvichku obuchali ubivat' rossiiskikh soldat v lagere Khattaba (Sniper Anna: How a young Moscow girl learnt to kill Russian soldiers in Khattab camps). Komsomolskaia Pravda, August 9, 2001. Available at http://www. kp.ru/daily/22608/9606/, last accessed on June 1, 2017.

${ }^{15}$ A recent hoax set up by journalism students (about the revival of a mythical TV series) has shown serious flaws in the work of some Ukrainian media outlets. Not only was the dubious information based on a single Facebook page, but it was also broadcasted without any verifications of the facts (see Anna Shamanska's "Old Dog, New Trick: 'Inspector Rex' Hoax Shows Ukrainian Journos' Gullibility”, RFE / RL, February 15, 2016. Available at http://www.rferl.org/content/ukraine-student-hoaz-shows-mediagullibility/27553928.html, last accessed on June 1, 2017).

${ }^{16} \mathrm{Na}$ Donbasi spetspriznachentsi zatrimali 19-richnu snaiperku (In Donbas, special forces arrested a 19-year-old sniper). January 12, 2015. Available at http://www. pravda.com.ua/news/2015/01/12/7054778/, last accessed on June 1, 2017.

${ }^{17}$ Ukraine's Security Service captured a 19-year-old terrorist sniper. Euromaidan Press, January 15, 2015. Available at http://euromaidanpress.com/2015/01/15/ukrainessecurity-service-captured-a-19-year-old-terrorist-sniper/, last accessed on June 1, 2017.

18 Text available at http://pesen.ru/publ/206-1-0-295; audio version available at http:// mp3-pesni.net, both last accessed on June 1, 2017.

${ }^{19}$ Text available at http://pesenok.ru/9/Igor-Jdamirov/tekst-pesni-Devochka-snayper; audio version available at https://www.youtube.com/watch?v=4T-xVZQgTpk, both last accessed on June 1, 2017. See also "Pesnia pro snaipershu" (Song about a female sniper), available at https://my.mail.ru/mail/baldin.anatolii/video/369/2087.html, last accessed on June 1, 2017. 
${ }^{20}$ See Solnechnyi udar (Sunstroke) by D. Linchevsky (http://artofwar.ru///inchewskij_d_i/ text_0070.shtml) or Fatima by S. Scherbakov (http://artofwar.ru/s/sherbakow_s_a/ fatimadoc.shtml). See also Kontrol'nyi vystrel (Test shot) by Afghan and Chechen veteran Nikolai Ivanov (http://rospisatel.ru/ivanov-kontrolny\%20vistrel.htm), all last accessed on June 1, 2017.

${ }^{21}$ Giurza: 'Belye kolgotki'. Eksmo-press 2003 (7,000 copies); republished in 2005 under the title Istrebitel' snaiperov (Sniper exterminator) in 15,000 copies.

${ }^{22} \mathrm{Na}$ iskhode poslednego chasa. Moscow: AST, 2002, published in thousands of copies, several reprints. Available at http://webreading.ru/det_/detective/fridrih-neznanskiyna-ishode-poslednego-chasa.html\#, last accessed on June 1, 2017.

${ }^{23}$ Moskovskaia auditoriia fil'ma Aleksandra Nevzorova "Chistilishche" (Moscow cinema audience of Chistilishche (Purgatory) by Alexander Nevzorov). FOM, April 9, 1998. Available at http://bd.fom.ru/report/cat/smi_tv/tvfilm/of19981406, last accessed on June 2, 2017.

${ }^{24}$ Zhenshchina-snaiper rasskazal o napadenii na rossiiskikh zhurnalistov (Woman-sniper told about the attack on Russian journalists). NTV.ru, June 17, 2014. Available at http://www.ntv.ru/video/870600/, last accessed on June 2, 2017.

${ }^{25}$ Shturmom namagalisia vziati boioviki s'ogodni selishche Shirokine (Insurgents tried today to seize Shirokine village). TSN.ua, March 9, 2015. Available at http://tsn.ua/ video/video-novini/shturmom-namagalisya-vzyati-boyoviki-sogodni-selische-shirokine. html, last accessed on June 2, 2017.

${ }^{26}$ Beslanskikh terroristov prikryvali pribaltiiskie snaipery (Beslan terrorist were covered by Baltic snipers). Lenta.ru, June 7, 2006. Available at http://www.lenta.ru/ news/2006/06/07/beslan/, last accessed on June 2, 2017.

${ }^{27}$ Interview with Vladimir Zhirinovsky on radio channel Ekho Moskvy (Echo of Moscow), August 11, 2008. Available at http://www.echo.msk.ru/programs/razvorotmorning/533185-echo.phtml, last accessed on June 2, 2017.

${ }^{28}$ See Neraskrytye tainy: Sushchestvoval li otriad snaipersh "Belyi chulok"? (Undisclosed secrets: Was there a White Tights sniper squad?) Documentary published on YouTube on March 15, 2014, produced by Moscow channel Doverie (Trust). Available at https:// www.youtube.com/watch?v=E-Ap7SqPFzo, last accessed on June 2, 2017; see also Russian Wikipedia page "Belye kolgotki".

${ }^{29}$ Sergei Filatov: Dudaeva podobrala Moskva (Sergei Filatov: Dudaev was chosen by Moscow). BBC interview, December 8, 2004. Available at http://news.bbc.co.uk/go/pr/ fr/-/hi/russian/russia/newsid_4079000/4079537.stm, last accessed on June 2, 2017.

${ }^{30}$ See, for example, Damien Gayle, "Has Blackwater been deployed to Ukraine?". Daily Mail, March 8, 2014. Available at http://www.dailymail.co.uk/news/article-2576490/ Are-Blackwater-active-Ukraine-Videos-spark-talk-U-S-mercenary-outfit-deployedDonetsk.html, last accessed on June 2, 2017. 
${ }^{31}$ Nigerian Mechanics Were Turned into "American Mercenaries and Chastisers" Who Had Come to Ukraine in Order to Fight Here. Stopfake, November 23, 2014. Available at http://www.stopfake.org/en/nigerian-mechanics-were-turned-into-americanmercenaries-and-chastisers-who-had-come-to-ukraine-in-order-to-fight-here/, last accessed on June 2, 2017.

${ }^{32}$ Nam nuzhna vsia Ukraina! (We need the whole of Ukraine!) Interview with the DPR Secretary of the Security Council of the DPR, Aleksandr Khodakovsky. Lenta.ru, March 30, 2015. Available at http://m.lenta.ru/articles/2015/03/30/khodakovskiy/, last accessed on June 12, 2017.

${ }^{33}$ NATOvskii snaiper-naemnik mog zastrelit' odnogo iz demonstrantov v Kieve (NATO sniper-mercenary could have shot a demonstrator in Kiev). January 23, 2014 (http://msk.mr7.ru/society/news/natovskiy-snayper-naemnik-mog-zastrelit-odnogoiz--1059552, last accessed on January 23, 2014; no longer available).

${ }^{34}$ Belye piatna chernogo oktiabria 93-go (The blind spots of black October). Moskovskii Komsomolets, October 3, 2003. Available at http://www.compromat.ru/page_13683. htm, last accessed on June 12, 2017. See also Amandine Regamey's "Le sniper sur le toit: Une rumeur d'octobre 1993", November 11, 2013. Available at http://russie. hypotheses.org/1342, last accessed on July 12, 2017.

${ }^{35}$ Opolchenets: Zhenshchiny-snaipery u aeroporta v Donetske streliali nashim v pakh (Militiaman: Women-snipers around Donetsk airport aimed at our groins). Life.ru, May 31, 2014. Available at http://lifenews.ru/news/134208, last accessed on June 12, 2017.

${ }^{36}$ See, for example, T. Martsenyuk \& G. Grytsenko \& A. Kvit (2016) "Invisible Battalion": Women's Participation in ATO Military Operations (Sociological Research). Available at http://www2.unwomen.org/-/media/field\%20office\%20eca/attachments/publications/ country/ukraine/invisible\%20batallion\%20study_eng_full.pdf?vs=2734, last accessed on June 12, 2017.

${ }^{37}$ Devushka-snaiper iz batal'ona 'Donbass': Poniala, chto ia na voine, kogda pogib nash boets (Girl-sniper from the 'Donbass' Battalion: I understood that I am at war when one of our soldiers fell). TSN News, September 21, 2014. Available at http://ru.tsn. ua/ukrayina/devushka-snayper-iz-batalona-donbass-ponyala-chto-ya-na-voyne-kogdapogib-nash-boec-387745.html, last accessed on June 13, 2017.

${ }^{38}$ Porazitel'naia skhozhest' Savchenko s legendarnoi ukrainkoi Pavlichenko shokirovala internet (The incredible similarity between Savchenko and legendary Ukrainian Pavlichenko shocked the Internet). Obozrevatel, April 22, 2015. Available at http:// obozrevatel.com/chronics/72916-porazitelnaya-shozhest-savchenko-s-legendarnojukrainkoj-pavlichenko-shokirovala-internet.htm, last accessed on June 13, 2017.

${ }^{39}$ Posted on September 10, 2015, on the Vkontakte account http://vk.com/love_separa.

${ }^{40}$ As a Muslim society, Chechen society is indeed also perceived as traditional, which can give an additional explanation to the focus on Baltic women-snipers, because Baltic societies are perceived as European ones. 
${ }^{41}$ See, for example, the testimonies on http://iremember.ru/memoirs/snayperi/, last accessed on June 13, 2017.

${ }^{42}$ Documentary film Chernomortsy (Black Sea fleet) by V. Beliaev (1942), available at http://www.net-film.ru/film-20435/, last accessed on June 13, 2017.

43 "The trigger finger of the Red Army girl sniper, credited by the Soviet military authorities with the death of 309 Germans, today was decorated with 'bright silk' nail polish", wrote the Philadelphia Inquirer on September 3, 1942. See also her description in The Baltimore News Post (September 10, 1942), "Wearing lipstick and bright pink nail polish", in Chicago News on September 26, 1942 ("On her nails, for the first time, she wore red polish"), and the headline of The Fresno Bee, on October 8 , 1942: "Tinted nails belie grim courage of Red girl sniper". All press clippings from the file about her trip in the USA can be found in the RGASPI (Rossiiskii gosudarstvennyi arkhiv sotsial'no-politicheskoi istorii (Russian State Archive of Socio-Political History)) in Moscow (fond 7M opis 2 ed khr 952).

${ }^{44}$ Bitva za Sevastopol' (Battle for Sevastopol), 2015.

${ }^{45}$ Zhenshchina-snaiper sovetovala federalam "berech organy" (Woman-snipers advised Russian Federation soldiers to "protect their parts"). RBK News, March 31, 2001. Available at http://top.rbc.ru/incidents/31/03/2001/42987.shtml, last accessed on June 13, 2017.

${ }^{46}$ Opolchenets: Zhenshchiny-snaipery u aeroporta v Donetske streliali nashim v pakh (Militiaman: Women-snipers around Donetsk airport aimed at our groins). Life.ru, May 31, 2014. Available at http://lifenews.ru/news/134208, last accessed on June 12, 2017.

${ }^{47}$ See the online dictionary at http://www.russki-mat.net/page.php?l=RuFr\&a=\%D0\%94, last accessed on June 13, 2017.

${ }^{48}$ English translation of the tales from https://russian-crafts.com/tales.html, last accessed on June 13, 2017.

${ }^{49}$ Human Rights violations in the Chechen conflict between autumn 1999 and February 2000. Report by the Organisation of Soldiers' Mothers of St. Petersburg to the April 2000 session of the Parliamentary Assembly of the Council of Europe (personal archives).

${ }^{50}$ See, for example, the story about the Russian sniper Anna (Snaipersha Anna: Moloduiu moskvichku obuchali ubivat' rossiiskikh soldat v lagere Khattaba (Sniper Anna: How a young Moscow girl learnt to kill Russian soldiers in Khattab camps). Komsomolskaia Pravda, August 9, 2001 (available at http://www.kp.ru/daily/22608/9606/) or about a Leningrad biathlonist (Olga Dobromyslova: Missiia nevypolnima (Mission Impossible). Rossiiskaia Gazeta, December 16, 2005 (available at http://www.rg.ru/2005/12/16/ chechnya.html), both last accessed on June 14, 2017. 


\section{REFERENCES}

Allport, Gordon W. \& Postman, Leo J. 1947. The Psychology of Rumor. New York: H. Holt and Co.

Astashkin, Nikolai 2003. I snova vzryvy, snova zhertvy... [Again Explosions, Again Victims...] Krasnaia Zvezda, May 21. Available at http://old.redstar. ru/2003/05/21_05/1_03.html, last accessed on June 2, 2017.

Azar 2016 = Azar, Il'ia. "Ia ee vzial i lichno peredal Plotnitskomu": Boets LNR rasskazal 'Meduze', kak zaderzhivali Nadezhdu Savchenko. [Fighter of the LNR told Medusa how Nadezhda Savchenko Was Arrested.] Meduza, March 21. Available at https://meduza.io/feature/2016/03/21/ya-ee-vzyal-i-lichno-peredal-plotnitskomu, last accessed on June 1, 2017.

Babchenko, Arkady 2016. Pokhishchennaia: Konets sudebnogo predstavleniia i nachalo torgovli. [Abducted: End of Court Performance and Beginning of a Business Transaction.] Spektr, March 22. Available at http://spektr.press/pohischennayakonec-sudebnogo-predstavleniya-i-nachalo-torgovli/, last accessed on May 31, 2017.

Baky, John S. 1994. White Cong and Black Clap: The Ambient Truth of Vietnam War Legendry. Viet Nam Generation: A Journal of Recent History and Contemporary Issues, Vol. 5, Nos. 1-4. Available at http://www2.iath.virginia.edu/sixties/HTML_ docs/Texts/Scholarly/Baky_White_Cong_01.html, last accessed on June 14, 2017.

Barden, Thomas E. \& Provo, John 1995. Legends of the American Soldiers in the Vietnam War. Fabula, Vol. 36, No. 3-4, pp. 217-229. http://dx.doi.org/10.1515/ fabl.1995.36.3-4.217.

Beevor, Antony 2009. D-Day et la bataille de Normandie. Transl. by J.-F. Sené \& R. Clarinard \& I. Taudière. Paris: Calmann-Lévy.

Begunova, Alla 2014. Angely Smerti: Zhenshchiny-snaipery, 1941-1945. [Angels of Death: Women-Snipers, 1941-1945.] Moscow: Veche.

Belibentsev, Dmitri 2006. Skorpiony protiv Belykh kolgotok. [Scorpions against White Tights.] Sovetskaia Chuvashia, June 27. Available at http://www.memo.ru/hr/ hotpoints/caucas1/msg/2006/06/m70558.htm, last accessed on June 13, 2017.

Bennett, Gillian 2005. Bodies: Sex, Violence, Disease, and Death in Contemporary Legend. Jackson: University Press of Mississippi.

Bennett, Gillian \& Smith, Paul (eds.) 1996. Contemporary Legend: A Reader. New York \& London: Garland Publishing.

Bloch, Marc 1999 [1921]. Réflexions d'un historien sur les fausses nouvelles de la guerre. Paris: Allia.

Bonaparte, Marie 1946. Mythes de guerre. Paris: PUF.

Bonhomme, Julien 2009. Les Voleurs de sexe: Anthropologie d'une rumeur africaine. Paris: Seuil.

Bourke, Joanna 1999. An Intimate History of Killing: Face-to-Face Killing in Twentieth Century Warfare. New York: Basic Books.

Campion-Vincent, Véronique \& Renard, Jean-Bruno 2002. De Source sûre: Nouvelles rumeurs d'aujourd'hui. Paris: Payot. 
Chapai, Artem 2015. Sluzhili dva “aidarovtsa”: O chem priniato molchat' na voine. [Two Aidar Members Served: What Is Not Talked About in the War.] The Insider, January 5. Available at http://www.theinsider.ua/politics/54a9af9fa9f76/, last accessed on June 14, 2017.

Collins, Randall 2009. Violence: A Micro-Sociological Theory. Princeton \& Oxford: Princeton University Press.

Dargo, Abdulla 1999. "Belye kolgotki” voevali v Dagestane. ["White Tights" Fought in Dagestan.] Nezavisimaia Gazeta, October 2. Available at http://www.ng.ru/ events/1999-10-02/stocking.html, last accessed on June 1, 2017.

Dégh, Linda 1991. What Is the Legend After All? Contemporary Legend, Vol. 1, pp. 11-38.

Dégh Linda 1996. What is a Belief Legend? Folklore, Vol. 107, pp. 33-46. Available at https://www.jstor.org/stable/1260912?seq=1\#page_scan_tab_contents, last accessed on June 14, 2017.

Dégh, Linda \& Vázsonyi, Andrew 1983. Does the Word "Dog” Bite? Ostensive Action: A Means of Legend-Telling. Journal of Folklore Research, Vol. 20, No. 1, pp. 5-34. Available at https://www.jstor.org/stable/3814298?seq=1\#page_scan_tab_ contents, last accessed on June 14, 2017.

Denber, Rachel 2014. Dispatches: Leaked Call, But Where's the Truth in Ukraine? Human Rights Watch, March 6. Available at http://www.hrw.org/news/2014/03/05/ dispatches-leaked-call-where-s-truth-ukraine, last accessed on June 12, 2017.

FIDH/CCL 2015 = Eastern Ukraine: Civilians Caught in the Crossfire. FIDH Center of Civil Liberties, No. 667a. Available at https://www.fidh.org/IMG/pdf/eastern ukraine-ld.pdf, last accessed on June 14, 2017.

Fine, Gary Alan \& Campion-Vincent, Véronique \& Heath, Chip (eds.) 2005. Rumor Mills: The Social Impact of Rumor and Legend. New Brunswick \& London: Aldine Transaction.

Fine, Gary Alan \& Ellis, Bill 2010. The Global Grapevine: Why Rumors of Terrorism, Immigration, and Trade Matter. New York: Oxford University Press.

Freytag, Claudia 2002. Kriegsbeute 'Flintenweib' Rotarmistinnen in deutscher Gefangenschaft. In: Swetlana Alexejewitsch (ed.) Mascha, Nina, Katjuscha: Frauen in der Roten Armee 1941-1945. Berlin: Links Verlag, pp. 32-36.

Gulzow, Monte \& Mitchel, Carol 1980. 'Vagina Dentata' and 'Incurable Venereal Disease': Legends from the Vietnam War. Western Folklore, Vol. 39, No. 4, pp. 306-316.

Héritier, Françoise 1996. Masculin / Féminin: La pensée de la difference. Paris: Odile Jacob.

Hohmann, Sophie 2015. Violence domestique dans le Caucase du Sud: Les exemples de l'Arménie et de l'Azerbaidjan. Revue d'études comparatives Est-Ouest, Vol. 46, No. 2, pp. 105-142. Available at https://receo.revues.org/1941, last accessed on June 15, 2017.

Horne, John \& Kramer, Alan 2001. German Atrocities, 1914: A History of Denial. New Haven, Conn.: Yale University Press.

Ianchenkov, Vladimir 2000. Dikie gusyni v belykh kolgotkakh. [Wild Geese in White Tights.] Trud, April 1. Available at http://www.trud.ru/article/01-04-2000/4238_ dikie_gusyni_v_belyx_kolgotkax.html, last accessed on May 31, 2017. 
Keneally, Meghan 2011. Taking on the Taboos: Vintage STD Posters Show How Patriotism and Prostitutes Played a Role in Postwartime Ad Campaign. Daily Mail, November 22. Available on http://www.dailymail.co.uk/news/ article-2064941/Vintage-STD-posters-Patriotism-prostitutes-played-role-postWWII-ad-campaign.html, last accessed on June 13, 2017.

Krylov, Aleksandr 1999. Suchka. [Bitch.] Available at http://alexanderterski.narod.ru/ songsres.files/suchka.htm, last accessed on June 13, 2017.

Langenhove, Fernand van 1916. Comment naît un cycle de legends: Francs-tireurs et atrocités en Belgique. Lausanne \& Paris: Payot. Available at http://www.archive. org/stream/commentnatuncy00languoft, last accessed on June 15, 2017.

Le Naour, Jean-Yves 2007. 'Mon flingot c'est cupidon', la sexualité du soldat. In: François Rouquet \& Fabrice Virgili \& Danièle Voldman (eds.) Amours, guerres et sexualité: 1914-1945. Paris: Gallimard / BDIC / Musée de l'armée.

Likhomanov, Petr 2014. Sport nizkikh dostizhenii. [Sport with Low Achievements.] Rossiiskaia Gazeta, June 3. Available at http://www.rg.ru/2014/06/02/ukrainkasite.html, last accessed on June 1, 2017.

Maetnaia, Elizaveta 2001. Volchitsy v belykh kolgotkah. [She-Wolves in White Tights.] Moskovskii Komsomolets, April 6. Available on http://www.memo.ru/hr/ hotpoints/N-Caucas/ch99/010406/mk0406a.htm, last accessed on June 13, 2017.

Maksakov, Vladimir 2014. 22 dnia v DNR. [22 Days in the DNR.] Colta.ru, November 11. Available at http://www.colta.ru/articles/society/5329, last accessed on June 2, 2017.

Medvedev, Evgeni n.d. Krovavoe leto v Benderakh. [Bloody Summer in Bendery.] Available at http://artofwar.ru/k/kazakow_a_m/text_0290.shtml, last accessed on June 13, 2017.

Melnikov, Ruslan 2014. Pimpochki dlia avtomata. [This Thingummy for a Machine Gun.] Rossiiskaia Gazeta, June 2, No. 6394. Available at http://www.rg.ru/2014/06/01/ batalyon-site.html, last accessed on June 13, 2017.

Oring, Elliott 1990. Legend, Truth, and News. Southern Folklore, Vol. 47, No. 2, pp. 163 177.

Oring, Elliott 2008. Legendry and the Rhetoric of Truth. Journal of American Folklore, Vol. 121, No. 480, pp. 127-166. Available at http://www.jstor.org/stable/20487594, last accessed on June 15, 2017.

Ponsonby, Arthur 1928. Falsehood in War-time: Propaganda Lies of the First World War. N.p.: George Allen and Unwin. Available at http://www.vlib.us/wwi/resources/ archives/texts/t050824i/ponsonby.html, last accessed on July 10, 2017.

Rasskazov 2001 = Rasskazov, Evgenii. Zima: maskirovat'sia, chtoby vyzhit'. [Winter: Camouflage to Stay Alive.] Sinopa, No. 1. Available at http://www.sinopa.ee/ kalashnikov/k2001/k0101/k010152/k010152.htm, last accessed on June 2, 2017.

Regamey, Amandine 2008. L'opinion publique russe et l'affaire Boudanov. The Journal of Power Institutions in Post-Soviet Societies, Vol. 8. Available at http://www. pipss.org/document1493.html, last accessed on June 15, 2017.

Regamey, Amandine 2011. Les femmes snipers de Tchétchénie: Interprétations d'une légende de guerre. Questions de Recherche / Research in Question, No. 35. Available at http://www.sciencespo.fr/ceri/sites/sciencespo.fr.ceri/files/qdr35.pdf, last accessed on June 15, 2017. 
Regamey, Amandine 2012a. The Weight of Imagination: Rapes and the Legend of Women Snipers in Chechnya. In: R. Branche \& F. Virgili (eds.) Rape in Wartime. London: Palgrave MacMillan, pp. 128-139. DOI: 10.1057/9781137283399.

Regamey, Amandine 2012b. Comparing Violence: Organ Theft Rumors in Chechnya and South America. Laboratorium, Vol. 3, pp. 42-66. Available at http://soclabo.org/ index.php/laboratorium/article/view/49, last accessed on June 15, 2017.

Rogozin, Dmitri 2010. Iastreby mira: Dneunik russkogo posla. [Hawks of the World: Diary of a Russian Ambassador.] Moscow: ANF. Available at http://lib.rus.ec/b/246440/ read, last accessed on June 12, 2017.

Romashov, Georgy 1995. Naemniki v Chechne: On khatu pokinul, poshel voevat'.... [Mercenaries in Chechnya.] Kommersant, No. 7, January 18. Available at http:// www.kommersant.ru/doc.aspx?DocsID=99614, last accessed on June 1, 2017.

Shcherbakov, Sergei n.d. Fatima. Available at http://artofwar.ru/s/sherbakow_s_a/ fatimadoc.shtml, last accessed on June 1, 2017.

Scheper-Hughes, Nancy 1996. Theft of Life: The Globalization of Organ Stealing Rumours. Anthropology Today, Vol. 12, No. 3, pp. 3-11. DOI: 10.2307/2783143.

Semelin, Jacques 2002. Analyser le massacre: Réflexions comparatives. Questions de Recherche / Research in Question, No. 7. Available at http://www.sciencespo.fr/ ceri/sites/sciencespo.fr.ceri/files/qdr7.pdf, last accessed on June 15, 2017.

Sieca-Kozlowski, Elisabeth 2008. Les liens indéfectibles entre la société et l'armée en Russie post-soviétique. In: Anne Le Huérou \& Elisabeth Sieca-Kozlowski (eds.) Culture militaire et patriotisme dans la Russie d'aujourd'hui. Paris: Karthala, pp. $147-170$.

Theweleit, Klaus 1987. Male Fantasies, Volume 1: Women, Floods, Bodies, History. Minneapolis: University of Minnesota Press.

Troshev, Gennadi 2001. Moia Voina: Chechenskii dnevnik okopnogo generala. [My War: Diary of a General in the Trenches.] Moscow: Vagrius. Available at http://www. soldat.ru/memories/troshev, last accessed on July 11, 2017.

Voronov, Vladimir 2004. Lubianskii Pul. [The Journalist Pool on Lubianka Square.] Index, Vol. 20. Available at http://www.index.org.ru/journal/20/voronov20.html, last accessed on May 31, 2017.

White, Luise 2000. Speaking with Vampires: Rumor and History in Colonial Africa. Berkeley \& Los Angeles \& London: University of California Press. Available at http://publishing.cdlib.org/ucpressebooks/view?docId=ft8r29p2ss\&brand=ucpre ss, last accessed on June 15, 2017. 


\title{
REPRESENTATION OF THE SNOWDEN SCANDAL IN THE ESTONIAN MEDIA: THE CONSTRUCTION OF THREATS AND FEAR
}

\author{
Mari-Liis Madisson \\ Institute of Philosophy and Semiotics \\ Institute of Social Studies \\ University of Tartu, Estonia \\ e-mail:ml.madisson@gmail.com
}

\begin{abstract}
The aim of this paper is to explicate how the leakages concerning details of the top-secret mass surveillance program PRISM launched by the United States government were contextualized in the Estonian public information space. The Snowden scandal received strong public feedback because this topic addressed even people who had normally kept their distance from politics. It touched the cornerstone of contemporary identities - the right for free Internet. The Internet is frequently associated with the freedom of expression, horizontal relations between citizens and state authorities, transparent governing, etc., and those characteristics are often interpreted as signs of the progressive and democratic nature of the medium. This study tries to explain how such positive connotations start to resonate with cultural fears of unregulated surveillance and non-transparent control.
\end{abstract}

Keywords: conspiracy theory, e-Estonia, identity creation, PRISM, semiotics of fear, technological determinism

\section{INTRODUCTION}

This article maps how different explanations of the Snowden scandal ${ }^{1}$ were constructed in the Estonian media. I explain what kind of key signifiers and strategies of association were relied on in the case of interpreting the socio-cultural impacts of PRISM ${ }^{2}$. For theoretical purposes, I have mainly relied on cultural semiotics, which defines culture as the sphere of organization of information) in human society as opposed to disorganization (entropy) (Ivanov et al. 1998: 33). The goal is to explain how different sign-systems model reality and how they co-function. It is important to note that cultural semiotics is not interested in reality in its entire diversity but rather in its sign-based models, and in most cases those models tend to be simplifying (Lotman 2001: 16-17). Therefore, 
my study concentrates on how the meanings of PRISM were articulated in the Estonian online media rather than the specific aspects concerning the mass surveillance program itself. Despite the fact that the analyzed representations were usually addressed to the so-called ordinary readers who do not have any special knowledge about contemporary information politics and Information and Communication Technologies (ICT) (and actually a vast majority of the authors also do not have that kind of expertise), it is relevant to study this material, because the sphere of meanings constructed around Snowden's leakages allows for exploring the common understandings and values that are connected with contemporary technologies and with the visions of information society in general.

A contemporary analysis of culture should not treat the Internet as a merely technological layer that affects our lives or as a place where social interaction occurs; it needs to explain how collective understandings, local and global identities are attached to it (Kelty 2010: 13). In order to explain why PRISM received such vast public feedback in Estonia, I have to place the Snowden scandal in a wider context of meanings of the new ICT. Many studies have outlined that a commonsense way of thinking about the developments of contemporary ICT is technological determinism (Ballinger 2011; Bell 2001; Hirst 2012; Morozov 2011; Mosco 1996, 2004; Sandywell 2006). To put it very briefly, technological determinism is a tendency to understand the relation between machines (technology) and people in a predominantly linear way: it is implied that technological developments directly influence social processes, and in some interpretations technology is even seen as the main cause thereof (Bell 2001: 65). According to Barry Sandywell (2006: 41), there is a bipolarized field of understandings behind contemporary ICT: "on the one side we have supportive responses by those who viewed the new technologies as instruments of liberation and progress (technologies of freedom) that 'change life'; on the other side we find discourses predicated upon fear and distrust (the new technologies undermine traditional institutions, reinforce existing inequalities, and so on)". Several authors state that the frameworks of technological determinism are deeply rooted in the Western cultural memory and the Internet, as social networking sites and smartphones are addressed in strikingly similar rhetorical frames that were used, for instance, for telegraph, electricity, radio, television, etc. (Hirst 2012; Mosco 2004). One common feature that characterizes the discourses of the impacts of technological innovation is the idea that new technology is leading to novel or even unprecedented social situations. New technologies have often been paired with hyperbolic phrases, such as 'the Information Age', 'the Electronic Era', and 'the Telecommunication Revolution', which indicate the constitution of a new era (Sandywell 2006: 41). A similar interpretational scheme is also prevalent in the context of the vision of new technological generations (e.g. 
generation $\mathrm{C}$, smartphone generation, etc.) that are believed to be dominated by new values and habits.

In the following, I will be focusing on the main values and both optimistic and pessimistic future scenarios that are associated with the contemporary ICT in Estonia. Firstly, the techno-utopian identity discourse, i.e., e-patriotism, will be introduced. E-patriotism highlights national IT-infrastructures and general IT-savviness of Estonians as important characteristics, which make us a progressive role model of active citizenship and participatory democracy for the rest of the world.

\section{TECHNO-UTOPIANISM: THE DISCOURSE OF CYBER DEMOCRACY AND E-ESTONIA}

Several authors have studied techno-utopian visions of the digital era and they have also critically explained the development of those ideas in different socio-cultural contexts (see Holmes 2005; Jordan 1999; Morozov 2011; Mosco 2004; Turner 2006; Söderberg 2013; etc.). The utopian visions of the Internet, and especially of social media, are usually built on an idea that new communicational resources are paving the way for the emancipation of passive media consumers. It is also believed that the online environment promotes inherently anti-authoritarian participatory communication (Kreiss \& Finn \& Turner 2011: 247; Morozov 2011: xiii-xiv; Mosco 2004: 113). The main distributers of the vision that the Internet is supporting democracy are IT enthusiasts, civic activists, and technology journalists. ${ }^{3}$ Some academics have also contributed to the elaboration of those techno-utopian understandings (see Gilder 1994; Negroponte 1995; Tapscott 1998). There are certainly also vernacular versions of the discourse of cyber democracy that relate it with local events, communal memory, and personal experiences.

After regaining independence, the cyber-optimistic discourse became an important dominant of the Estonian future-oriented identity. Public self-descriptions started to emphasize the importance of national IT solutions that facilitate the development of deliberative democracy and the emancipation of citizens. The rapid development of the e-state was understood as a key to success: as something that makes Estonia to stand out against the background of other post-Soviet countries and brings us closer to the Western values. Aro Velmet (2015) has pointed out that the articulation of the success story of e-Estonia started at the beginning of the 1990s and it was predominantly related to the actuation of the Internet-based system of the state institutions. One important milestone of the progressive and innovative e-state was achieved in 2000 , when 
the meetings of the Estonian Parliament became paper-free. The other center of e-Estonia was an idea that contemporary ICT can help to reduce social and regional inequalities and increase participation in the discussions on public topics. This kind of rhetoric arose with the popularization of the Tiger's Leap project, which started in 1996. The Tiger's Leap was a state-run project, the main goal of which was to develop Estonian digital infrastructure and which put a special emphasis on providing computers for educational institutions. In the first decade of the twenty-first century, the success narrative of e-Estonia was supplemented with the topics of civic education and participatory democracy (Velmet 2015: 140).

The example of e-Estonia has been highlighted as one of the most outstanding projects of national branding. The meaning package of e-Estonia is anchored to the idea that clever IT-solutions, used on many levels of the state, make Estonia a modern, innovative, and easily approachable target for tourists and foreign investors (see Jansen 2012: 85-88; Kulcsár \& Yum 2012: 198; Mosco 2004: 172). The cyber-attacks on Estonia $(2007)^{4}$ enriched the success story of e-Estonia with a heroic nuance; they demonstrated that the Estonian paperless governing system cannot be fatally destroyed, and, what is more - after this violation, the NATO Cooperative Cyber Defence Centre of Excellence was established in Tallinn (Jansen 2012: 88). As indicated above, those cyber-utopian visions also have an important role in Estonian inwardly oriented identity discourse (at the official but also vernacular level). It is even possible to observe a certain Estonian e-patriotism. ${ }^{5}$ One of the central tropes of that kind of self-description is pointedly summarized by Aro Velmet (2015: 139), who claims that Estonian e-patriotism is built on Jakob-Hurt's ${ }^{6}$ famous national-romantic idea that Estonians cannot be a great nation in population but they can be a great nation in spirit. A contemporary version of this formulation is articulated around the topic of e-residency: in 2025, small Estonia will have 10 million e-residents ${ }^{7}$ (ibid.). A similar frame of self-description also applies to the idea of spreading Estonian successful public IT solutions (ID-card system; e-elections, e-school, system of digital prescriptions, etc.) around the world. Other important signifiers of the discourse of Estonian e-success ${ }^{8}$ are: Skype, paperless bureaucracy, e-healthcare system, wide Wi-Fi coverage, generation of the Tiger's Leap (and general IT-savviness of Estonians); Toomas Hendrik Ilves as the President of Twitter, ${ }^{9}$ the world record in start-ups per person. ${ }^{10}$ This listing could be continued with a number of aspects but I believe that it already demonstrates that basically everything connected with the Internet and innovative digital solutions carries strong positive connotations in Estonia - it is understood as something progressive and liberating. 
It is important to note that techno-utopian explanations often follow cybernetic-informational epistemology, i.e., people tend to identify themselves and the new IT-driven society by relying on the features that are used for describing hypermedia; for example, a nonhierarchical or decentralized nature, interactivity, etc. (Boyer 2010: 79-80; see Madisson \& Ventsel 2015: 9). Those characteristics are rounded with a strong axiological charge; they are seen as a guarantee of civil liberties and progress. It is assumed that the interaction opportunities, provided by the Internet, revolutionarily grow the potentiality of deliberative democracy and facilitate two-way or bottom-up communication between active citizens and state authorities (Holmes 2005: 9, 84). Also, it is believed that thanks to the experience in online-participation and content creation, a new generation of citizens is developing who will end the era of social hierarchies that are characteristic of rigid military systems and bureaucracy, and replace them with horizontal power relations based on shared interests and voluntariness (Mosco 2004: 89; Turner 2006: 38). Utopian visions see the Internet as an alternative public sphere or forum, which is relatively unspoiled by censoring authorities or commercial interests; thus different interest groups can spread their voices there, and individuals navigating the Internet can be part of enriching dialogues between various viewpoints (that are sometimes even contrary to their own worldview) (Atton \& Hamilton 2008: 81; McQuail 2003: 111; Ballinger 2011: 175-177). Great expectations have been placed on e-governance that should make legislative processes more transparent, allow cooperation with different grassroots organizations, and widen the possibilities of communication between citizens and representatives in the political system (Mosco 2004: 113; Söderberg 2013: 1282).

In Estonia, the discourse of e-democracy, especially the topic of inclusive or horizontal politics, reached one of its peaks just a few months before Snowden's leakages. At the beginning of 2012, there took place a huge social resentment and resistance to the Estonian government's plan to ratify the Anti-Counterfeiting Trade Agreement (ACTA) ${ }^{11}$, which was compromising the popular idea of the free Internet. The wave of public protests - which were extraordinarily active and crowded for Estonia - showed that the topic really resonated with contemporary Estonian identity. In the second half of 2012, the public debates about the transparency and inclusiveness of Estonian governance intensified. As a result of this discussion, 17 citizens-activists and academicians made a public statement, called Harta 12 (Charter 12), which demanded that serious steps be made in order to have a healthy democracy and civil society in Estonia. As a result of this public statement, President Ilves assembled a meeting of the activists of civil society, political parties, opinion leaders, and political scientists; the meeting was organized in the Ice Cellar building in Kadriorg on November 21, 
2012. ${ }^{12}$ In that meeting, it was decided that proposals for improving Estonian democracy and governing system would be developed through the combined efforts of the general public and then submitted to the Riigikogu (the Parliament of Estonia). The submitting process was organized via a crowd-sourcing platform Rahvakogu (People's Assembly) ${ }^{13}$ and everybody who had an Estonian ID was welcomed to attend.

E-democracy and other components of the success story of the e-state have a significant role in contemporary identity discourse of Estonia but it would be unbalanced to say that there only exist optimistic understandings about the social outcomes of the contemporary ICT. The following sub-chapter introduces the dystopian visions of the computer era and demonstrates that the worries that arose in the reception of PRISM were not created from scratch.

\section{DYSTOPIAN VISIONS OF THE COMPUTER ERA}

It seems that dystopian understandings of an ICT-driven society are rather peripheral in public discussions. Those visions are often mentioned in the context of subcultures that share left-wing, in some cases extreme left, views (e.g. radical environmentalists, anti-globalization movement, anarcho-primitivism, etc.). This may also be the reason why there is not much academic research concentrating on that topic (see Fisher \& Wright 2001; Fuchs 2013; Sandywell 2006). Usually, the dystopian visions of society seem to re-articulate the gloomy scenarios presented in William Gibson's novel Neuromancer (1984). Namely, they describe a future world where the triumph of computers has increased the inequality between big corporations / IT-experts and ordinary people, where private information has become an oxymoron, and where people have been alienated from basic human values and from face-to-face communication (Bell 2001: 22; Dodge \& Kitchin 2001: 230; Fisher \& Wright 2001; Sandywell 2006: 42). The techno-dystopian discourse also relies on tropes of surveillance society; for example, the idea of global authoritarian control $\left(\mathrm{NWO}^{14}\right)$, Big Brother (see Sandywell 2006: 48), and of masses of brainwashed citizens.

From time to time, we can observe in the Estonian media the articulation that sees the Internet and all kinds of smart technology as the main cause of social problems. For example, there is an understanding that heavy social media usage is turning adolescents uneasy and uncommunicative in offline interactions; or that the generation that is used to liking, sharing, and other phatic activities is no longer able to think analytically and see the big picture. ${ }^{15}$ Also, it is believed that the elderly people are more marginalized and discarded from social life because of the overall massive usage of computers. ${ }^{16}$ Sometimes the system of e-elections is questioned, especially the aspect of reliability and 
security. ${ }^{17}$ Also, the projects of e-participation (e.g. Rahvakogu) are discredited for their relatively opaque and populist agendas. ${ }^{18}$ But in comparison to e-success stories or cyber-democracy, the dystopian discourse is much narrower in Estonia. It is related to concrete age-groups, or specific issues, while the techno-utopian visions are articulating proportionally more essential and comprehensive social changes.

The analysis of the reception of PRISM allows for shedding some light on the expansion of dystopian explanations (that usually originate in the sociocultural periphery) into the dominant explanations of PRISM. The Estonian example offers rich and concentrated material for analyzing how cultural fears resonate with techno-utopian visions, because e-discourse has a focal role in the future-oriented Estonian identity.

\section{THE RECEPTION OF PRISM IN THE ESTONIAN MEDIA}

To grasp representations from professional and alternative media, ${ }^{19} \mathrm{I}$ analyzed opinion articles of the main newspapers and popular blog postings as well as the comments that followed both. I studied 35 opinion articles and 140 comments that were explicitly discussing leakages by Edward Snowden, from the mass electronic surveillance data mining program PRISM or the NSA. From the mainstream media, I analyzed articles and comments from Postimees (The Courier, as the biggest Estonian daily newspaper), Eesti Ekspress (Estonian Express, as the biggest Estonian weekly newspaper), and Delfi (as the biggest Estonian Internet-based news portal, which has the most popular forum for reader comments). I also analyzed postings of two blogs - Memokraat and Persona in fieri - as representative examples of the alternative media. I decided to focus on those particular blogs because they concentrated on the topic of PRISM most explicitly, and also because they are popular among the readers who are interested in contemporary information politics. The major focuses of analysis were: the dominant topic of the representation and key-signifiers; the attribution of agency; and the usage of tropes. In order to explain the general socio-cultural mechanisms that were framing the reception of PRISM, I synthesized the semiotics of fear, media sociology, and cultural studies.

\section{ARTICULATION OF THREATS AND FEAR}

PRISM-like surveillance technologies are rounded with a feeling of opacity and absence of control, and that kind of feeling of disorganization is organically connected with the articulation of collective threats and fears. It seems that 
already at first sight, the text corpus that surrounds PRISM is dominated by the explicit indication of the feelings of anxiety and fear. Hereby, I would like to outline just a couple of opening sentences of an opinion article:

Snowden's revelations documentarily confirmed to us what we have always been afraid of. Namely, that large countries are very comprehensively watching the so-called free Internet and by doing that, they do not hesitate to violate the most basic human rights. (Põder 2013)

Yesterday Glenn Greenwald published another article in The Guardian about the leakages of 29-year-old Edward Snowden. This time the story was terrifying. Very terrifying, and it transcended the former leakage many times. (Turk 2013)

Yuri Lotman (2007: 108-110) has claimed that ambiguous or poorly explained social situations are normally accompanied by a rapid increase in the mythology of threats. Almost all texts present PRISM and its social impacts as something alarming and at least potentially dangerous. Different authors articulate various fears connected with mass surveillance technologies. The general rule that I detected is that authors publishing in the mainstream media talk about possible threats and their future scenarios are sketched in quite an abstract manner. The alternative media reflects threats of surveillance much more explicitly; dangers are often seen as something that is already significantly affecting the current developments and sometimes they are also connected with (unpleasant) social events from the past. Fears take much more drastic and clearer shape in the representations of the alternative media; they find their reference in the sense of specific enemies, settings, and victims. In the following, I will outline the most prevalent ways in which different articles and comments articulate fears connected with PRISM.

\section{Phobophobia: The Fear of Fear}

In some interpretations, Snowden's leakages and their socio-cultural impacts are rounded with a certain meta-fear, i.e. phobophobia - a concern about the devastating impacts of the collective feeling of fear and vulnerability. Phobophobia is built upon an understanding that society lacks the competence to solve an acute problem and the present situation can only deteriorate because it is assumed that the general atmosphere of anxiety and disorder will make people behave irrationally and there is a danger that they become easily manipulated. Several authors are convinced that there is a lack of experts who are able and/or willing to adequately explain the social implications that contemporary surveillance 
technologies have for ordinary people. Neeme Korv has noted that, in order to maintain and protect democratic values, it is highly essential to orientate in the informational chaos that is surrounding the topic of PRISM. He also mentions that there are not many people who explain this topic in a clear manner: "We have no other choice than to rely on those who are skilled and capable of explaining the ongoing events as simply as possible" (Korv 2013). Urve Eslas (2013) points out that even the world's leading technical journalists are incompetent at explaining the social impacts of PRISM. People also express concern that the general lack of knowledge about the topic can lead to superficial and destructive discussions which may facilitate the way to biased spokesmen and populist rhetoric. Some authors point out that an uncontrollable creation of black and white interpretations and conspiracy theories is taking place and producing ironic and distrustful attitudes towards the establishment and free information society in general (see Tuisk 2013). Authors are worried that the emerged 'headlessness' may paralyze the perception of more important topics; for example, as people are panicking about Big Data, they may not notice the threats posed by Meta Data, which may have more serious consequences (see Filippov 2013).

Generally, the discourse of phobophobia places the possibilities of overcoming this informational chaos in the hands of hypothetical experts. Those experts have to be IT-geniuses who also possess knowledge about international relations, military systems, and lobby organizations. And, what is more, they should not be motivated by self-profit and they should be extremely skilled in communicating those intricate aspects in a way that is understandable to the so-called ordinary people. At the same time, there is a tendency to stress a certain responsibility that Estonians (as an IT-savvy nation) have in the context of refuting the destructive attitudes towards the ICT. It is pointed out that our IT-experts should contribute to creating more transparent IT-solutions and also to profound analyses of the ongoing situation. For instance, Silver Meikar (2013) notes: "As a leading country in the Freedom House's annual index of Internet freedom, Estonia has to take the role of an example and show that transparent and honest governing is possible".

Some interpreters see that the atmosphere that connects contemporary ICT with the atmosphere of anxiety and clutter is created by a spiteful secret cabal. It is claimed that the panic that followed Snowden's leakages was consciously cultivated by media institutions and the main goal thereof was to incite the fear of terrorism, which would make it possible to legalize even more exhaustive surveillance actions. For example, one blogger writes:

The media is producing objects of popular hatred used as building stones for the Republic of Hatred, which is based on the fear of an individual to fit into the category of the hate object. It forces citizens to be infinitely loyal to 
the existing regime and to embrace the banal truths that the mainstream media offers. (Persona in fieri 2013) ${ }^{20}$

That kind of understanding about the connections of the media and the malicious elite will be more thoroughly explained in a sub-chapter that talks about the NWO conspiracies.

\section{The fear of jeopardizing global democracy and/or human rights of individual citizens}

The idea that the opaque surveillance politics is making some countries drastically more privileged in the world arena is massively articulated. Authors are also worried that the power of some interest groups and/or countries has grown exponentially and is undermining the trust in democracy and international law. In most cases it is understood that the USA (CIA, NSA, Pentagon), some lobby organizations, and IT corporations are now strongly dominating the world's information politics. For example, Siim Tuisk (2013) has noted:

One must have permission to intercept the citizens of the allied states, and there must be some control over the issuance of those permits; but the present system relies on secret court and secret decisions and on senators who should exercise surveillance. We are not given a full picture of who and when is allowed to intercept.

It is believed that the surveillance departments have become uncontrollable in the sense of collecting and archiving information and the international law is unable to regulate their actions because they are moving in juridical no man's land. The question posed by one author promptly concludes one of the general directions in the public discussions in the Estonian media: "If we have to choose between the benevolence of the almighty judge and the power of the law then we must choose the latter, mustn't we?" (Lobjakas 2013) In many cases, the agency behind PRISM is referred to, based on the metaphor of Big Brother. Also, many other keywords from the popular discourse of dystopia have become activated, for example, thought police, mind control, panopticon-shaped society, secret eye, etc. One important layer of this discourse is drawing parallels with the memories of Soviet intelligence and propaganda services; for instance, people talk about gumshoe $\mathrm{men}^{21}$, spies $^{22}$, and the KGB archives of the new era. One of the authors sketches vivid associations with deportation:

On the level of information technology, the compilation of the list of deportation may be reduced to keyword search, separation of the suspicious 
group, and to the logistical question of how many containers are needed. (Irve 2013)

Similar threats are also reflected when different authors try to map the influence that surveillance technologies have on ordinary citizens. As one may expect, on this level, the authors are identifying with possible victims and they outline their fears more expressively. The most common issue is that the privacy of the individual (as one key value of democracy) is seen as undermined. Lobjakas (2013), for example, mentions: "PRISM guided us to the era of post-privacy". Another author worries that all procedures that were previously protected with confidentiality, for instance, personal files and letters, financial transactions, communication between doctor and patient or between lawyer and client, are now disclosed (Turk 2013). In the most pessimistic views, surveillance technologies are understood as something potentially life-threatening. One internet commenter cynically writes:

If we accept that drones may use data from our computers for deciding upon the execution of random people whose guilt has not been proven in court, then we are accepting a world where men in black masks organize raids and people disappear forever only because they said something bad about the establishment. ${ }^{23}$

The linkage between drones and the surveillance program turned out to be quite popular; namely, associations were drawn with the counter-terrorist operations in the Middle East and North Africa, where drone attacks were used. In the context of PRISM, drones are associated with the gathering of secret information but also with the execution of dangerous individuals and with the intimidation of people. Drones may fulfill a function similar to that of mystical black helicopters in conspiracy beliefs, which were especially popular in the 1990s. Alasdair Spark has pointed out that the image of a black helicopter represented the agents of malignant state power, acting covertly. Black helicopter theories made it possible to express the fears about the capabilities of powerful military technologies (Spark 2003a: 125-126). Drones resonate with similar anxieties but as they are consumer goods that are potentially available for a vast segment of people, the relations between drones and evil state authorities are articulated more vaguely.

In both cases authors share an opinion that the essence of the surveillance problem is located outside us as Estonians, as people of a small country, as Europeans. It is understood that we are the ones who are harmed and manipulated by the external forces. As already implied, central agency is ascribed to the USA (the state and big corporations) and to IT-geniuses who comprehend the surveillance technology. Only a few interpreters see a slight chance that Estonia or the so-called ordinary people can improve the present situation. 


\section{The fear that PRISM is a sign of New World Order's conspiracy}

An important center for the reception of PRISM, especially in the alternative media but also in some newspaper articles, is a fear of conspiracy. In the broadest sense, conspiracy can be defined as malicious actions of a covert group, which influence the development of an important social event or series of events. ${ }^{24}$ The topic of PRISM almost 'naturally' generates interpretations that refer to conspiracy, because after Snowden's leakages, it became widely known that a covert surveillance system exists that affects a large number of people. But in order to call an interpretation a conspiracy theory, one more feature must be present: it is an understanding that a secretly acting group has consciously evil intentions (Madisson 2014: 287). Usually conspirators are presented as morally corrupt, motivated by the wish of establishing absolute power; the desire for limitless self-profit is also highlighted as one of the main motivators of the secret cabal (see Ballinger 2011: 268; Fenster 2008: 101; Knight 2008: 176).

In the reception that connects PRISM with conspiracy, I detected two tendencies: 1 ) some authors refer to a possible conspiracy; 2) others are convinced that a vast and long-term conspiracy exists and is already determining important social events. Authors publishing in the mainstream media are afraid that the USA has created a mass surveillance system which is used for lucrative interests and for gaining disproportionately large power. This kind of interpretation sees malicious intentions of the USA in a quite narrow network of connections, and it is usually associated only with a secret self-profitable surveillance system, which has been achieved via making covert deals with big IT-companies. We can also observe that kind of indication to a possible conspiracy in some of the representations analyzed in the previous sub-chapter. The harmful effect of conspiracy is usually (as a threat to democracy or to human rights) seen on the level of possibility and it is projected into an indefinite future. Normally those interpretations do not explicate that the USA has already significantly harmed other countries. It is important that sometimes the indication of conspiracy is done in a knowingly humorous or exaggerative manner; for instance, one author points out: "Today we do not have a clear answer for which purpose Yankees are gathering and storing data. Conspiracy theorists are having days full of inspiration" (Luts 2013). Another author notes:

In the world struggle for power is intensifying; on one side of the front line are those who write the code, on the other side are those who write the laws, i.e., global web-giants versus countries. But what if this struggle is illusory and the opponents are making agreements with one another? We will hear about the secret protocol later or our children will. I hope it is all a conspiracy theory. (Korv 2013) 
Some other interpretations see PRISM as a direct result of an extensive conspiracy, and those interpretations prevail in the alternative media but also in some newspaper articles. PRISM is understood as part of a malignant New World Order (NWO) conspiracy that has intentionally catalyzed public problems and catastrophes. ${ }^{25}$ In short, the NWO conspiracy implies that a malignant grouping has systematically acted for a long time and it has been absorbed into a global economic and political elite and also into the mainstream media, education, and military systems. The goal of this conspiracy is to create a global centralized regime - a totalitarian One World Government - and to gain an absolute control over the movements and even over the thoughts of ordinary citizens (Ballinger 2011: 64; Madisson \& Ventsel 2015: 18; Spark 2003b: 537). Some sources of the alternative media interpret PRISM as part of a secret plot, started centuries ago; they connect it, for example, with the systemic actions of the Illuminati. ${ }^{26}$ Also, it is quite a widespread tendency to connect the surveillance system with the Bilderberg Group. ${ }^{27}$ PRISM is quite often referred to as having direct relations with the September 11 attacks and/or Boston Marathon bombing. It is believed that the terrorist attacks were an inside job of Western conspirators and it was needed for legitimating some further actions, namely, the Iraq War and the legalization of PRISM. This tendency of interpretation is illustrated by the following posting:

They want to keep power in their safe hands and that is why PRISM is needed: it makes it easier to maintain the power. Terrorism is a good excuse for developing the system and justifying the expenses. As the Boston bombing shows, some capital injection for developing PRISM is still needed. ${ }^{28}$

Another commenter writes that " $9 / 11$ was not the thing that they present to us, it was $100 \%$ fake-terror, an inside job". ${ }^{29}$ Sometimes it is indicated that the cyber-attacks that took place in 2007 were a similar inside job as well. It is believed that the covert aim of organizing the attacks was to create NATO's Cyber Defence Centre which allows for a more sophisticated surveillance over the Estonian population. As one of the commenters has put it:

After the cyber "attacks" of 2007, Estonia has had a chance to enjoy the status of a star of cyber defense, and also NATO's Cyber Defence Centre was brought here. In the Western information security circles rumors have been encircling for a long time that NATO's Cyber Defence Centre has had a big role in creating the Stuxnet. What can we actually be proud of ?30

A tendency to use quotation marks while talking about terrorist assaults, the danger of terrorism or cyber-attacks is very common in the discourse of the NWO, as it is used for ridiculing the official explanations. 
It is important to note that the mainstream media is seen as the key-supporter of establishing a dystopian surveillance society. Among other things, the media is accused of covering up the actual facts about 9/11; of causing the general atmosphere of fear and anxiety (see the chapter on phobophobia) that allowed for justifying the creation of PRISM; of inadequate and misleading media coverage of the activities of the NSA; and of demonizing Snowden. ${ }^{31}$ Although in the reception that sees PRISM as part of the NWO, the main agency is ascribed to the decadent elite, the authors perceive themselves in a remarkably higher position than the ignorant masses of so-called ordinary citizens. They feel that they have not been influenced by the systemic brainwash and have a privilege to think independently, and see, at least partly, through the manipulations of conspirators. Conspiracy theorists hope that soon the secret manipulations can be revealed because the present situation abounds in the signs of a significant breakthrough. Namely, some authors stress that thanks to Snowden's leakages and various channels of the alternative media (which introduce the idea of the NWO), people are becoming aware of the secret manipulations of mainstream structures and getting more skeptical. For example, one of the comments reads: "People are becoming more and more awake and today you cannot pass with the mainstream-shit as you did at the time of 9/11 and in the past, and I am only glad about it". ${ }^{32}$ Similarly, another commenter points out: "Luckily people are increasingly awakening, reading the news of the alternative media and making up their own minds about what to believe and what not". ${ }^{33}$

\section{PRISM AND THE SEMIOTIC MECHANISMS OF FEAR GENERATION}

As demonstrated in the previous chapter, the reflection of Snowden's leakages is dominated by the discourse of fear, which connects PRISM to instant threats but also to some abstract dangers. In the following section, I will try to explain what the main types of meaning-making are that those interpretations relied on and what kind of socio-cultural causes led to the creation of that kind of discourse of fear. According to Yuri Lotman, the things that are new and placed outside tradition have increased symbolism. The semiotization of things creates the mythology of things (Lotman 2007: 87). People start to see more in the ICT than just technology: technology is contextualized as a sign of prosperity or disaster. Vincent Mosco (2004: 32) has pointed out that contemporary ICT embodies a sense of liminality, as people tend to perceive that they are living in an era of changing paradigms or ruptures. They feel that the innovation has not actually achieved its complete effect but the present situation is full of all 
kinds of signs of that new era. The constant articulation of technology-driven social changes or even ruptures does not allow for concentrating on the other aspects of social reality, which would add some historical and socio-cultural dimensions to those visions (ibid.: 49). Mosco's observation has been developed further by Martin Hirst in the context of the discourse of Twitter/Facebook revolution or Revolution 2.0. ${ }^{34}$ He claims that the perception of the very strong social significance of ICT-innovations allows people to get stuck in their bias of convenience and leads to ignoring the complexities, controversies, and contingent aspects of the issue (Hirst 2012: 7). Albrecht Hofheinz (2011: 1423) has conceptualized that kind of continuous search for political utopia through the next generation of technology as a NEXTOPIA. People's interpretational horizon gets limited by a preoccupation with the new, and we tend to hail the progressive nature of the ICT without placing it in the context of historical developments and human agency.

The discourse of e-Estonia was also characterized by the NEXTOPIA-tendency: the ICT was understood as a revolutionary means for facilitating democracy, civil society, transparent governing, etc. In many cases, PRISM's reception demonstrated the reversal of those utopian visions and the replacement with dystopian understandings. It is important to note that the perception of the significance of the social impacts of technologies remained relatively constant in both cases; the positive charge of meaning was just replaced with a negative one. For example, the important keywords of the e-success story (e.g. the NATO Cooperative Cyber Defence Centre, e-healthcare system, paperless bureaucracy) started to signify a hidden danger - a wolf in sheep's clothing. The constituent topics of the discourse of e-democracy, such as horizontal power-relations, freedom of expression, and transparent governing were, in many cases, replaced with the images that are familiar from the description of totalitarian societies. People started spreading the vision that the ICT was rather undermining democratic freedoms (e.g. the privacy of the citizen) and contemporary information politics (on a national and also international level) is anything but clear and unbiased.

It is noteworthy that the socio-cultural meanings of PRISM were often created by expressing modern versions of the fear discourse about the Soviet state surveillance. Eda Kalmre has pointed out that the image of the KGB, which is skillfully and malignantly using the newest achievements of technology, has not lost its topicality in contemporary Estonia. The old fears are often interwoven with the documentary material about the Soviet security agencies and emotional memories of the more or less personal contacts with the KGB (Kalmre 2013: 50). One important center of the vernacular discourse about the Soviet panopticon is the understanding that via the surveillance technology the state is omnipres- 
ent in the private activities of the citizens (Astapova 2015: 55). These kinds of associations about blurring the private and public spheres were frequently activated in the reception of PRISM. Many interpreters were drawing parallels between contemporary ICT and interception technologies (especially phone tapping) and violent practices of the KGB. Some authors also relied on the fictional dystopias, for example, Huxley's Brave New World or Orwell's 1984. These kinds of interpretations often assumed that the contemporary surveillance regime is reaching so far that it can actually control and even direct the thoughts of the individuals, and expressed the idea of an emerging post-private age. In addition, it is important to stress that often the explanations that extensively articulate various worries and fears are occasionally interlaced with ironic and jocose stories that ridicule the surveillance anxieties (Astapova 2015: 55). Also, in the (public) PRISM reception some authors were articulating a connection with dystopian regimes in a hypothetical and exaggerating manner, but some others seriously recognized the alarming signs of the creation of a totalitarian surveillance society.

Lotman has pointed out that one reason why substantial technological innovations are causing distress and skepticism is that they increase the unpredictability of social developments. Another significant factor is the unprincipled nature of new technologies, i.e., they can serve anyone's interests (Lotman 2007: 76). In the context of mapping the social impacts of PRISM, one important tendency was the expression of the lack of knowledge. Sometimes it took the shape of phobophobia - people expressed worries about the atmosphere of fear itself. It was believed that contemporary ICT and its covert unpleasant 'extras' were not entirely understandable for so-called ordinary citizens, and also for the IT-experts and technology journalists. In addition, it was indicated that this topic is also out of the reach and control of international law. Leonidas Donskis has elaborated a concept of technocratic demonology to describe such tendencies of interpretation. The understandings dominated by technocratic demonology tend to see intricate technological/biological manipulations (that are principally unintelligible for normal people) behind unpleasant social phenomena. It is felt that the people who are affected by those manipulations do not have any possibility to resist them (Donskis 2002: 115). As PRISM's reception has demonstrated, the contemporary surveillance technologies were often mapped by using the image of Big Brother or a faceless Power which embodies the imperceptible power and control. As this power does not have an easily localizable center of reference, the image of Big Brother is causing feelings of incapacity, weakness, and fear of a totalitarian future among its interpreters (see Sandywell 2006: 47-48). 
Donskis (2002: 115) has outlined that it is believed that the evil technocratic forces can be beaten only by relying on the guidance of experts who are aware of the supreme forms of technological knowledge. The indication of such hypothetical experts was also present in the context of the reception of PRISM. People sensed that they could not be sure of the benevolent intentions of the IT-geniuses and they identified with the position of a helpless victim (ibid.: 116). However, not all the authors were taking a passive position - some of them stated that they (and IT-savvy Estonians in general) were responsible for a detailed ascertainment of the social impacts of PRISM; for example, in the context of performing and mediating expert analyses, contributing to an international discussion about legal aspects, etc. On the other hand, there was a considerable proportion of authors who decided not to devote their attention to the aforementioned nuances (as evil code-writers have designed it in a way that is not graspable to ordinary people). They rather focused on opening up various aspects of a malicious secret society that was seen as responsible for creating the mass surveillance system.

Conspiracy theory is quite a universal framework that makes it possible to explain the main causes of an unpleasant social event, to map how it is connected with more distant and closer historical developments, and who the leading charters behind it are (see Madisson 2014). The hallmark of the conspiracy theory is that everything is perceived to be connected, meaningful, and motivated by the evil intentions of the conspirators (Melley 2002: 69). One of the essential cultural functions of the conspiracy theories is to extenuate the frustration that is caused by sensing the complex, uncontrollable, and unpredictable nature of the ongoing social processes. In the context of PRISM, I observed the creation of the NWO conspiracy theories that talked about the creation of the global totalitarian regime. Those interpretations placed the surveillance program in a causal chain with the September 11 attacks, the Boston Marathon bombing, and the systemic spreading of fear and anxiety in the mainstream media.

\section{CONCLUSION}

This article showed that the articulation of the social impacts of the surveillance program was significantly affected by technologically determinist selfdescriptions prevailing in Estonian culture. E-discourse was (and actually still is) one of the most important cornerstones of Estonian identity. A belief that new technologies had mainly positive and innovative impacts (e.g. e-democracy, free movement of information, freedom of speech) was highly questioned in the light of Snowden's leakages. PRISM's reception demonstrated that in many 
aspects the techno-utopian sphere of meaning was inverted and replaced with a dystopian one. The contemporary surveillance technology was interpreted by drawing parallels with keywords from the descriptions of totalitarian societies. People started generating associations with Soviet memories (e.g. activities of the KGB and censoring), fictional dystopias, and contemporary NWO conspiracy theories.

At the time of writing the article, two and a half years had passed since Snowden's leakages, and now it is possible to see that the aforementioned dystopian visions have fallen back into the periphery of public discussions. The articulation of the e-success story still has a significant role in Estonian national branding and in self-descriptions of various groups and enterprises, but it is not dominated by the topics of e-democracy and the emancipation of active citizens. It rather talks about e-Estonia as an economic Nirvana and the key components of that discourse are e-consumption, quick bureaucratic processes, and cost-effectiveness (Velmet 2015: 141).

\section{ACKNOWLEDGEMENTS}

This study was supported by the projects "Semiotic analysis of discourses of e-Estonia" (PHVFI 16937), "Semiotic modelling of self-description mechanisms: Theory and applications" (IUT 2-44), and "Conceptualizations and experiences with public and private in technologically saturated society” (PUT 44).

\section{NOTES}

1 Edward Joseph Snowden is an American computer professional, who worked for the United States National Security Agency (NSA). He became world-famous in May 2013, when he leaked information about the top-secret mass surveillance system PRISM to journalists of The Washington Post and The Guardian. His revelations caused an international scandal and led to heated public discussions about covert mass surveillance, government secrecy, and information privacy (see https://en.wikipedia.org/wiki/ Edward_Snowden, last accessed on May 15, 2017).

${ }^{2}$ PRISM is a clandestine surveillance program, under which the NSA collects internet communications from the major US internet companies (e.g. Microsoft, Yahoo!, Google, Facebook, YouTube, Skype, Apple). PRISM was launched in 2007 under Bush administration and it was connected with the Protect America Act (see https://en.wikipedia. org/wiki/PRISM_(surveillance_program, last accessed on May 15, 2017).

3 Several studies have outlined that technology journalists (e.g. from the Wired magazine) are eminently the most prevalent creators of techno-utopian interpretation (see Boyer 2010; Hirst 2012; Hofheinz 2011). 
4 The cyber-attacks that began on April 27, 2007, in the context of the disagreement between Estonia and Russia about the relocation of the Bronze Soldier (Soviet World War II war memorial) and paralyzed many important websites of public institutions and private companies, including the Estonian Parliament, ministries, newspapers, broadcasters, and banks.

5 See Velmet 2015; Hinsberg 2015.

6 Jakob Hurt (1839-1907) was a prominent Estonian folklorist, theologian, and linguist, who played a significant role in Estonian national awakening.

7 E-residency of Estonia is a status by which non-residents can gain a secure digital identity issued by Estonia, (see https://en.wikipedia.org/wiki/E-residency_of_Estonia, last accessed on May 15, 2017). The main authors of that vision (Taavi Kotka, Ruth Annus, and Siim Sikkut) hope that in ten years Estonia, a small country with 1.3 million population, will have ten million e-residents (see http://uudised.err.ee/v/ eesti/4455dc8a-824c-434a-92c3-27af94202806, last accessed on May 15, 2017).

8 The following articles offer quite concentrated examples of the success story of e-Estonia (see http://www.bbc.com/news/business-22317297; http://www.economist.com/blogs/ schumpeter/2013/07/estonias-technology-cluster, both last accessed on May 15, 2017).

9 In 2013, American media-edition BuzzFeed nominated Estonian President Ilves the President of Twitter (see https://www.buzzfeed.com/maxseddon/the-president-oftwitter?utm_term=.gdpJnbBYpX\#.hgJYEaBAGW, last accessed on May 15, 2017); this event received quite lively feedback in Estonian media and it fortified the image of Ilves as a leading figure of e-Estonia. Ilves has played a significant part in articulating the success story of e-Estonia from its very beginning. He was one of the main initiators of the Tiger's Leap program when he was Estonian ambassador in the USA in the 1990s. As president (Ilves was Estonian president in 2006-2016), he actively participated in discussing various cyber-issues and thus was called the spokesman of cyber-security.

${ }^{10}$ See http://www.economist.com/blogs/schumpeter/2013/07/estonias-technology-cluster, last accessed on May 15, 2017.

11 The Anti-Counterfeiting Trade Agreement (ACTA) is a multinational treaty for the purpose of establishing international standards for the enforcement of intellectual property rights. ACTA aims to establish an international legal framework for targeting counterfeit goods, generic medicines, and copyright infringement on the Internet, and would create a new governing body outside existing forums, such as the World Trade Organization, the World Intellectual Property Organization, and the United Nations (see https://en.wikipedia.org/wiki/Anti-Counterfeiting_Trade_Agreement, last accessed on May 1, 2017). ACTA's ratification discussions were accompanied by heated debates in Estonia and they led to crowded public demonstrations in the winter of 2012 (see more about ACTA's reception in Estonia in Madisson \& Ventsel 2015).

${ }^{12}$ See https://www.president.ee/en/president/institutions/147-estonian-cooperationassembly/8313-ice-cellar-initiative/layout-institution.html, last accessed on July 3, 2017.

${ }^{13}$ See https://www.rahvakogu.ee/, last accessed on May 15, 2017.

${ }^{14}$ NWO is an abbreviation of New World Order. It is used for referring to a systemic global conspiracy that aims to create a global centralized regime: Totalitarian One World Government. 
${ }^{15}$ See, e.g., http://www.diplomaatia.ee/artikkel/kuidas-internet-meid-rumalaks-muudab/, last accessed on May 15, 2017.

${ }^{16}$ See, e.g., http://tarbija24.postimees.ee/548092/kihnu-kummekond-eakat-tegid-arvutigalahemat-tutvust, last accessed on May 15, 2017.

${ }^{17}$ See, e.g., http://www.delfi.ee/news/paevauudised/eesti/savisaar-paremparteid-voitsidvalimised-e-valimiste-tulemusi-voltsides?id=66073466, last accessed on May 15, 2017.

${ }^{18}$ See, e.g., http://arvamus.postimees.ee/1180468/andrei-korobeinik-rahvakogu-2-0, last accessed on May 15, 2017.

19 This article relies on the definition of the alternative media that is elaborated by Chris Atton and James Hamilton, who stress that the alternative media proceeds "from dissatisfaction not only with the mainstream coverage of certain issues and topics, but also [...] emphasizes alternatives to, inter alia, conventions of news sources and representations; the inverted pyramid of news texts; the hierarchical and capitalized economy of commercial journalism; the professional, elite basis of journalism as a practice; the professional norm of objectivity; and the subordinate role of audience as receiver. Alternative media, at least its ideal form, is produced outside mainstream media institutions and networks" (Atton \& Hamilton 2008).

${ }^{20}$ See also http://ekspress.delfi.ee/arvamus/hans-h-luik-juba-selgus-et-usa-vilepuhujasnowden-on-nohik-ja-friik?id=66279302, last accessed on May 16, 2017.

${ }^{21}$ An equivalent to the Estonian word $n u h k$. Gumshoe man is "an old slang term for a detective or investigator (police-affiliated or private). Shoes in the late 1800s were made of gum rubber - the soft-soled precursors of the modern sneaker. The phrase 'to gumshoe' meant to sneak around quietly as if wearing gumshoes" (see http://www. urbandictionary.com/define.php?term=gumshoe, last accessed on May 16, 2017).

${ }^{22}$ In Estonian in this context the term koputaja (knocker) is used. It refers to a citizen who is secretly gathering information about the people around him or her (e.g. at work or at school) and passing it on to the KGB.

${ }^{23}$ See http://ekspress.delfi.ee/news/paevauudised/andrei-hvostov-vilepuhujad-ja-tapjad roonid.d?id=66587085\&com $=1 \& n o=0 \& s=1$, last accessed on May 16, 2017.

${ }^{24}$ I agree with the scholars of conspiracy theories who claim that sometimes conspiracies happen and thus it is possible that some conspiracy theories prove correct (see, e.g., Birchall 2006: 34). But I also underline that the aim of my research is not to decide upon the truth-value of conspiracy theories but rather to analyze how those explanations are constructed.

${ }^{25}$ I have to emphasize here that the reception that mapped PRISM as a part of conspiracy is not coherent, authors stress different and sometimes even controversial aspects, and views also differ in their degree of radicalism.

${ }^{26}$ See, e.g., a comment from July 5, 2013 (15:29) to the article at http://ekspress.delfi.ee/kuum/ hans-h-luik-usa-luure-voimsam-presidendist-voimsam-kohtust?id=66389498\&reg=0, last accessed on May 16, 2017. 
${ }^{27}$ The Bilderberg Group, established in 1954, involves European and North American political elite, experts from industry, finance, academia, and the media. See, e.g., http:// personainfieri.wordpress.com/2013/06/22/liberalismi-hauakaevajad/, last accessed on May 16, 2017.

${ }^{28}$ See a comment from June 13, 2013 (12:36) to the article at http://ekspress.delfi.ee/ arvamus/janek-luts-george-orwell-ma-ju-hoiatasin?id=66280568, last accessed on May 16, 2017.

${ }^{29}$ A comment from August 15, 2013 (11:52) to the article at http://ekspress.delfi.ee/kuum/ andrei-hvostov-vilepuhujad-ja-tapjadroonid?id=66587085, last accessed on May 16, 2017.

${ }^{30}$ A comment from August 23, 2013 (15:12) to the article at http://ekspress.delfi.ee/kuum/ andrei-hvostov-vilepuhujad-ja-tapjadroonid?id=66587085, last accessed on May 16, 2017. Stuxnet is a malicious worm-type computer virus, identified in 2010 . It is believed that Stuxnet was designed to attack the computer systems of Iran.

${ }^{31}$ See, e.g., http://ekspress.delfi.ee/arvamus/hans-h-luik-juba-selgus-et-usa-vilepuhuja-snowden-onnohik-ja-friik?id=66279302; http://personainfieri.wordpress.com/2013/06/22/liberalismihauakaevajad/, both last accessed on May 16, 2017.

${ }^{32}$ Comment on June 12, 2013 (20:00) to the article at http://ekspress.delfi.ee/arvamus/ hans-h-luik-juba-selgus-et-usa-vilepuhuja-snowden-on-nohik-ja-friik?id=66279302, last accessed on May 16, 2017.

${ }^{33}$ Comment on June 12, 2013 (19:54) to the article at http://ekspress.delfi.ee/arvamus/ hans-h-luik-juba-selgus-et-usa-vilepuhuja-snowden-on-nohik-ja-friik?id=66279302, last accessed on May 16, 2017.

${ }^{34}$ The term Twitter/Facebook revolution or Revolution 2.0 is used to refer to uprisings in Iran, Tunisia, and Egypt in 2009-2011. It is often believed that the driving force of those events was social networking sites.

\section{REFERENCES}

Astapova, Anastasiya 2015. Negotiating Belarusianness: Political Folklore Betwixt and Between. Tartu: University of Tartu Press. Available at http://dspace.ut.ee/ handle/10062/49509?locale-attribute=en, last accessed on May 17, 2017.

Atton, Chris \& Hamilton, James F. 2008. Alternative Journalism. London \& Thousand Oaks \& New Delhi \& Singapore: SAGE.

Ballinger, Dean Ross 2011. Conspiratoria: The Internet and the Logic of Conspiracy Theory. Diss. (PhD Thesis). The University of Waikato. Available at http:// researchcommons.waikato.ac.nz/handle/10289/5786, last accessed on May 17, 2017.

Bell, David 2001. An Introduction to Cybercultures. London \& New York: Routledge.

Birchall, Clare 2006. Knowledge Goes Pop: From Conspiracy Theory to Gossip. Oxford \& New York: Berg.

Boyer, Dominic 2010. Digital Expertise in Online Journalism (and Anthropology). Anthropological Quarterly, Vol. 83, No. 1, pp. 73-95. https://doi.org/10.1353/anq.0.0114. 
Dodge, Martin \& Kitchin, Rob 2001. Atlas of Cyberspace. Harlow \& London: Pearson Education Ltd. Available at http://www.kitchin.org/atlas/contents.html, last accessed on May 17, 2017.

Donskis, Leonidas 2002. Vandenõuteooria kui "teise" demoniseerimine: Karl Popperi vandenõuteooria kontseptsioon. [Conspiracy Theory as Demonizing of the "Other": Concept of Karl Popper's Conspiracy Theory.] Vikerkaar, Nos. 8-9, pp. 103-116. Available at http://www.digar.ee/arhiiv/et/perioodika/34529, last accessed on May 17, 2017.

Eslas, Urve 2013. Suur vend ja väike tüütu õde. [Big Brother and Small Annoying Sister.] Postimees, June 20. Available at http://arvamus.postimees.ee/1276146/ urve-eslas-suur-vend-ja-vaike-tuutu-ode, last accessed on May 16, 2017.

Fenster, Mark 2008. Conspiracy Theories: Secrecy and Power in American Culture. Minneapolis \& London: University of Minnesota Press.

Filippov, Madis 2013. Ilves: Suure Venna kõrval tuleks tähelepanu pöörata Väikesele Õele. [In Addition to the Big Brother, Attention Should Be Paid to the Little Sister.] Postimees, July 5. Available at http://www.postimees.ee/1290800/ilves-suure-vennakorval-tuleks-tahelepanu-poorata-vaiksele-oele, last accessed on May 16, 2017.

Fisher, Dana R. \& Wright, Larry Michael 2001. On Utopias and Dystopias: Toward an Understanding of the Discourse Surrounding the Internet. Journal of Computer-Mediated Communication, Vol. 6, No. 2. http://dx.doi.org/10.1111/j.1083-6101.2001.tb00115.x.

Fuchs, Christian 2013. Societal and Ideological Impacts of Deep Packet Inspection Internet Surveillance. Information, Communication and Society, Vol. 16, No. 8, pp. 1328-1359. http://dx.doi.org/10.1080/1369118X.2013.770544.

Gibson, William 1984. Neuromancer. London: Grafton Books.

Gilder, George 1994. Life After Television: The Coming Transformation of Media and American Life. New York \& London: W.W. Norton \& Company.

Hirst, Martin 2012. One Tweet Does Not a Revolution Make: Technological Determinism, Media and Social Change. Global Media Journal: Australian Edition, Vol. 6, No. 2, pp. 1-12. Available at http://www.hca.westernsydney.edu.au/gmjau/archive/ v6_2012_2/martin_hirst_RA.html, last accessed on May 17, 2017.

Hinsberg, Hille 2015. E-riik kui uus normaalsus ja selle piirid. [E-State as a New Normality and Its Borders.] Sirp, May 8. Available at http://www.sirp.ee/s1artiklid/c21-teadus/e-riik-kui-uus-normaalsus-ja-selle-piirid/, last accessed on May 17, 2017.

Hofheinz, Albrecht 2011. Nextopia? Beyond Revolution 2.0. International Journal of Communication, Vol. 5, pp. 1417-1434. Available at http://ijoc.org/index.php/ ijoc/article/view/1186, last accessed on May 17, 2017.

Holmes, David 2005. Communication Theory: Media, Technology and Society. London: SAGE.

Irve, Jaagup 2013. NSA ja Eesti: küsimata küsimused. [NSA and Estonia: Unasked Questions.] Postimees, June 26. Available at http://arvamus.postimees.ee/1281460/ jaagup-irve-nsa-ja-eesti-kusimata-kusimused, last accessed on May 16, 2017.

Ivanov, V. \& Lotman, J. \& Pjatigorski, A. \& Toporov, V. \& Uspenskij, B. 1998. Tezisy k semioticheskomu izucheniiu kul'tur / Theses on the Semiotic Study of Cultures / Kultuurisemiootika teesid. Tartu: Tartu University Press. Available at http://dspace.ut.ee/bitstream/handle/10062/54550/theses_on_the_semiotic_ocr. pdf? sequence=1\&isAllowed=y, last accessed on May 17, 2017. 
Jansen, Sue Curry 2012. Redesigning a Nation: Welcome to E-stonia, 2001-2018. In: Nadia Kaneva (ed.) Branding Post-Communist Nations: Marketizing National Identities in the "New" Europe. New York \& Abington: Routledge, pp. 79-98.

Jordan, Tim 1999. Cyberpower: The Culture and Politics of Cyberspace and the Internet. London \& New York: Routledge.

Kalmre, Eda 2013. The Human Sausage Factory: A Study of Post-War Rumour in Tartu. Amsterdam \& New York: Rodopi.

Kelty, Christopher 2010. Introduction: Culture In, Culture Out. Anthropological Quarterly, Vol. 83, No. 1, pp. 7-16. Available at https://muse.jhu.edu/issue/19733, last accessed on July 3, 2017.

Knight, Peter 2008. Outrageous Conspiracy Theories: Popular and Official Responses to 9/11 in Germany and the United States. New German Critique, Vol. 35, No. 1_103, pp. 165-193. http://dx.doi.org/10.1215/0094033X-2007-024.

Korv, Neeme 2013. Avatud maailma ohud. [Dangers of the Open World.] Postimees, June 17. Available at http://arvamus.postimees.ee/1272192/neeme-korv-avatudmaailma-ohud, last accessed on May 16, 2017.

Kreiss, Daniel \& Finn, Megan \& Turner, Fred 2011. The Limits of Peer Production: Some Reminders from Max Weber for the Network Society. New Media \& Society, Vol. 13, No. 2, pp. 243-259. http://dx.doi.org/10.1177/1461444810370951.

Kulcsár, László \& Yum, Young-ok 2012. One Nation, One Brand? Nation Branding and Identity Reconstruction in Post-Communist Hungary. In: Nadia Kaneva (ed.) Branding Post-Communist Nations: Marketizing National Identities in the "New" Europe. New York \& Abington: Routledge, pp. 193-212.

Lobjakas, Ahto 2013. Ameerika salasilm. [American Secret Eye.] Postimees, July 2. Available at http://arvamus.postimees.ee/1287584/ahto-lobjakas-ameerika-salasilm, last accessed on May 16, 2017.

Lotman, Juri 2007. Tehnikaprogress kui kulturoloogiline probleem. [Technology Progress as a Culturological Problem.] In: M. Lotman (comp.) Hirm ja segadus: Esseid kultuurisemiootikast. Tallinn: Varrak, pp. 69-90.

Lotman, Mihhail 2001. Paradoksaalne semiosfäär. [Paradoxes of Semiosphere.] In: Kajar Pruul (ed.) Kultuur ja plahvatus. Tallinn: Varrak, pp. 215-226.

Luts, Janek 2013. George Orwell: Ma ju hoiatasin! [George Orwell: I Did Warn You!] Eesti Ekspress, June 13. Available at http://ekspress.delfi.ee/arvamus/janek-lutsgeorge-orwell-ma-ju-hoiatasin?id=66280568, last accessed on May 1, 2017.

Madisson, Mari-Liis 2014. The Semiotic Logic of Signification of Conspiracy Theories. Semiotica, Vol. 202, pp. 273-300. http://dx.doi.org/10.1515/sem-2014-0059.

Madisson, Mari-Liis \& Ventsel, Andreas 2015. Grupuskulaarne identiteediloome paremäärmuslaste võrgusuhtluses. [The Formation of Groupuscular Identity in the Web Communication of the Estonian Extreme Right.] Methis: Studia humaniora Estonica, Vol. 15, pp. 8-27. Available at http://www.methis.ee/arhiiv/ methis-nr-15-kevad-2015, last accessed on May 17, 2017.

McQuail, Denis 2003. McQuaili massikommunikatsiooni teooria. [McQuail's Mass Communication Theory.] Tartu: Tartu Ülikooli Kirjastus.

Meikar, Silver 2013. Avatus ja läbipaistvus taastaks usalduse. [Openness and Transparency Would Restore Trust.] Postimees, June 17. Available at http://arvamus. postimees.ee/1272534/silver-meikar-avatus-ja-labipaistvus-taastaks-usalduse, last accessed on May 16, 2017. 
Melley, Timothy 2002. Agency Panic and the Culture of Conspiracy. In: Peter Knight (ed.) Conspiracy Nation: The Politics of Paranoia in Postwar America? New York: New York University Press, pp. 57-81.

Mosco, Vincent 1996. The Political Economy of Communication: Rethinking and Renewal. London: SAGE.

Mosco, Vincent 2004. The Digital Sublime: Myth, Power, and Cyberspace. Cambridge, Mass.: MIT Press.

Morozov, Evgeny 2011. The Net Delusion: The Dark Side of Internet Freedom. New York: PublicAffairs.

Negroponte, Nicholas 1995. Being Digital. New York: Vintage Books.

Persona in fieri 2013 = Liberalismi hauakaevajad. [Gravediggers of Liberalism.] June 22. Available at https://personainfieri.wordpress.com/2013/06/22/liberalismi-hauakaevajad/, last accessed on May 16, 2017.

Põder, Märt 2013. Mis teeb vilepuhujaks? [What Makes You a Whistleblower?] Postimees, July 11. Available at http://arvamus.postimees.ee/1297560/mart-poder-mis-teebvilepuhujaks, last accessed on May 16, 2017.

Sandywell, Barry 2006. Monsters in Cyberspace Cyberphobia and Cultural Panic in the Information Age. Information, Communication \& Society, Vol. 9, No. 1, pp. 39-61. http://dx.doi.org/10.1080/13691180500519407.

Söderberg, Johan 2013. Determining Social Change: The Role of Technological Determinism in the Collective Action Framing of Hackers. New Media and Society, Vol. 15, No. 8, pp. 1277-1293. http://dx.doi.org/10.1177/1461444812470093.

Spark, Alasdair 2003a. Black helicopters. In: Peter Knight (ed.) Conspiracy Theories in American History: An Encyclopedia. Santa Barbara \& Denver \& Oxford: ABCCLIO, pp. 124-126.

Spark, Alasdair 2003b. New World Order. In: Peter Knight (ed.) Conspiracy Theories in American History: An Encyclopedia. Santa Barbara \& Denver \& Oxford: ABCCLIO, pp. 536-539.

Tapscott, Don 1998. Growing Up Digital: The Rise of the Net Generation. New York: McGraw-Hill.

Tuisk, Siim 2013. Kas Eestil jätkub julgust? [Will Estonia Have Enough Courage?] Postimees, June 12. Available at http://arvamus.postimees.ee/1267174/siim-tuiskkas-eestil-jatkub-julgust, last accessed on May 16, 2017.

Turk, Karmen 2013. Karmen Turk: Minu kirjade ja dokumentidega tutvutakse julgeoleku huvides? [My Letters and Documents Are Perused for the Sake of Security?] Postimees, August 1. Available at http://arvamus.postimees.ee/1318758/ karmen-turk-minu-kirjade-ja-dokumentidega-tutvutakse-julgeoleku-huvides, last accessed on May 16, 2017.

Turner, Fred 2006. From Counterculture to Cyberculture: Stewart Brand, the Whole Earth Network and the Rise of Digital Utopianism. Chicago \& London: The University of Chicago Press.

Velmet, Aro 2015. E-kodanikud ja e-tarbijad: Kaks lugu 21. sajandi eestlusest. [E-Citizens and E-Consumers: Two Stories about the 21st-Century Estonianess.] Vikerkaar, Nos. 10-11, pp. 139-147. Available at http://www.digar.ee/arhiiv/et/ perioodika/42024, last accessed on May 17, 2017. 


\title{
FROM THE EDITORIAL BOARD
}

\section{ZEROING IN ON PERFORMANCE 2.0: FROM SERIALIZATION TO PERFORMATIVE ENACTMENTS}

\author{
Antti Lindfors \\ University of Turku, Finland \\ e-mail:anmili@utu.fi
}

\begin{abstract}
This article explores the notions of performativity and performance in digital environments from the combined perspective of linguistic anthropology and folkloristics. In order to bring these diverging conceptual, methodological, and disciplinary traditions into mutual contact, an intermediary heuristic term of "performative enactments" is introduced. Performative enactments are elaborated as events of communicative sign behavior that foreground and make use of the principle of performativity, although not performances proper in the sense of manifesting a specific "mode of communication" (Bauman 1984). Two different cases of digital communication are analyzed, the first manifesting an instance of everyday SMS messaging between two friends, the second concerning the so-called Per-Looks media event that took place in Finland in October 2012. Both cases are approached as materially durable performative enactments with methodological attention laid on poetic patterning understood as a textually diffuse form of performativity.
\end{abstract}

Keywords: diagraph, enactment, iconicity, irony, linguistic anthropology, parallelism, parody, performance, performativity, poetics, text messaging

One of the mainstays of folkloristic investigations since the $1960 \mathrm{~s}$, not least in the American context, has been a focus on performances, primarily verbal in nature, but increasingly also nonverbal, choreographic, material, visual, technologically mediated, or otherwise. Folklore, verbal art, and other patterned expressive forms and practices are understood as being typically performed for others' emotional and cognitive uptake, evaluation, participation, and possible enjoyment in interactional events specifically "keyed" to highlight responsibility for communicative competence (most notably after Bauman 1984 [1975]). Quite early on, the viewpoint of performance was translated onto what has been termed studies on computer-mediated communication or CMC (e.g. Kirschenblatt-Gimblett 1996), also succinctly rephrased as digital discourse (Thurlow \& Mroczek 2011). However, the specific epistemology of digital performances, 
it seems to me, has been somewhat lacking. First of all, are performances necessarily keyed in digital or text-based environments, and do they constitute a recognizable mode of communication? If they are (not) keyed, how do we signal, recognize, and apprehend them? As importantly, what are the implications of approaching expressive practices in digital environments from the perspectives of performativity and performance as variously understood in linguistics and linguistic anthropology, cultural theory, and folkloristics?

Performativity and performance are by now established keywords and conceptual hubs in various disciplinary fields, and the paradigm of performance studies is somewhat famous for its eclecticism. They are both, however, used in a confusing variety of ways. A disclaimer regarding what we here mean by speaking of performativity and performance, then, is in order at the outset. There are two discursive and disciplinary traditions related to performativity and performances that I would like to explicate here in order to position myself appropriately. Crudely put: firstly, in linguistics and linguistic anthropology, performativity typically refers to a principle of functional efficacy, to the actional aspect of discourse and communicative sign behavior. This tradition has evolved from John Austin's (1962) original meditations on the "illocutionary force" of certain utterances (tokens of the type of speech acts he first labeled as "performatives") onto the current situation, in which performativity is understood as pervasive of all discourse although variating along several intersecting dimensions, such as metapragmatic explicitness, discursive localizability, relative "defeasibility", etc. (Lempert \& Fleming 2014; Duranti 2004). Relatedly, in cultural theory broadly understood, performativity is generally conceptualized as reproduction and reiteration of social and cultural norms: identity and subjectivity as repetitive practices within historical, social, cultural, political, and other constraints (see Barad 2007: 57-66).

Secondly, folklore scholars have typically oriented towards performativity in the context of specifically marked events and a "mode of communication" (Bauman 1984 [1975]: 9), which is further associated with responsibility for communicative competence, as already pointed out. Summarizing the main tenets of the perspective of folkloristics on such performances proper, Simon J. Bronner (2012: 30) notes that "while variations exist in the use of performance, for most American folklorists applying the concept, the important principles are that: folklore is identified as aesthetically marked events (rather than textual items) situated in an observable, specific frame or stage conducive to artistic communication (usually small groups and settings set apart from ordinary life); performers take responsibility for presentation of this artistic material to an audience; performers strategically shape expressions in response to the immediate context and personal motivations, public purposes, and collateral effects; 
and perceptions of the meaning of the performance may vary with different segments of the audience and performers, and in different times and settings, and those perceptions are valid and discoverable in ethnographic observation".

I would like to also add or rather clarify that these performances proper to folkloristic interest - often enacted and analyzed as multimodal configurations - are typically conceptualized as accomplishments of intentional subjects, whereas the relations between intentionality and the principle of performativity remain relatively contested (Bauman 2012; Duranti 2015, esp. chapter 2; cf. also Lloyd 1999; Zwagerman 2010). ${ }^{1}$

The point worth restating here is that whereas performativity refers to a principle (of reiterative efficacy), performance refers to an event or perceivable action (see also Fischer-Lichte (2008), who emphasizes the distinction). That is, the two notions belong to conceptually and logically distinct domains, so that the larger principle of performativity is possibly seen as encompassing singular instances of performance (which, in turn, gather much of their force from performativity). In order to bring these diverging traditions into mutual contact, I will align myself primarily with the aforementioned linguistic anthropological tradition, in order to shed light on certain events or situations of communicative behavior in digital environments that are also interesting for folklore scholars and other analysts of culture and communication - I prefer to call them performative enactments. The significance of generating an intermediary, heuristic term of performative enactments is to leave open the resilient and culturally loaded questions regarding the level of intentionality, agency, responsibility, situational emergence and markedness, as well as aesthetic value associated with various deployments of performativity, which seem to function as primary qualifications of performances proper in the folkloristic tradition. ${ }^{2}$ Performative enactments are thus heuristically understood as events of communicative sign behavior that foreground and make use of the principle of performativity, although not performances proper in the sense of manifesting a specific mode of communication. ${ }^{3}$

Enactment provides a useful and relatively unburdened term for interrogating and problematizing certain contact points as well as differences between the two broad methodological traditions related to performativity and performance. Like performance, enactment refers to events and action, but in the sense of typically foregrounding decentralized, networked, or diffuse agency as well as indeterminate or extended temporality. As such, the notion of enactment can be particularly useful in approaching communicative events in digital environments that inscribe (verbal) communication as durable, visual trace to be apprehended by interlocutors. Insofar as digital communication foregrounds durable materiality and thus potentially calibrates or extends the temporality 
of communicative events (Buccitelli 2012: 75-78), digital environments seem to provide specific grounds for the scaffolding of performative enactments. What is more, enactment orients us toward performative assemblages between human and non-human actors, such as technological, material, and discursive objects. For Maria Schwertl (2016: 169), who draws from post-actor-network theorist Annemarie Mol, "enactment is a way to look at practices while looking at humans and objects" insofar as enactment forms "the conjuncture of diverse human and non-human actors who interact to create the situation and its entities or objects".

My argument is twofold. Firstly, I suggest that when studying performative enactments in digital environments, folklorists have to apprehend and engage with the principle of performativity theorized in linguistic anthropology. In short, this is the type of performativity that renders speech behavior and communication into effective action and can be hypothesized as also constituting the "micro-level" of performances proper. Accordingly, this route makes it hypothetically possible to detect and problematize specific folkloric performance practices that might be characteristic for digital environments.

Secondly, I will underscore that an important key to approach performative enactments in digital environments is constituted by poetics, and poetic parallelism in particular. Poetics is here designated as a function of communicative sign behavior, in which the performative efficacy of an instance of semiosis is amplified by reflexive juxtaposition of co-textual units of utterance. Poetics is thus one form of performativity, characterized as highly distributed and textually diffuse in its formal organization (Lempert \& Fleming 2014), and presumably a very productive one in digital environments for reasons explicated below. As known, Roman Jakobson (1960) originally characterized the poetic function of language very broadly as sequential juxtaposition of corresponding units of utterance within a compositional whole, i.e., as phonetical, grammatical, or syntactic units, words, symbolic articulations, or even structural or narrative sequences that are understood as indexing each other co-textually (Pressman 1994: 471; Glick 2012; cf. Tannen 2007 [1989]: 9). ${ }^{4}$ The significance of adopting the concept here is, however, to use it as a specific and folkloristically sensible gateway into the discussions of performativity, which in analysis is usefully complemented by related terms such as dialogic resonance, parallelism, and metapragmatic iconicity. These complementary terms will be introduced and explicated at appropriate places during the analysis. 


\section{DIGITAL AFFORDANCES FOR POETICS AND PERFORMATIVITY}

In an article on digital performances as seen from the perspective of folkloristics - performance 2.0 in the author's coinage - Anthony Buccitelli (2012: 78) lists "serialization" as one of the characteristic principles of digital discursive interaction. By serialization he refers to the fact that in digital environments, including traditional discussion forums, instant messaging, social networking sites such as Facebook, Instagram, and Youtube, singular messages are by necessity discrete and sequentially positioned one after another. Buccitelli writes:

In contrast to a face-to-face context, where there is often room for overlapping or intersecting forms of speech, action, or expression by different participants, the structure of the technological environment in which many digital performances occur requires that such expressions take place sequentially rather than in direct juxtaposition. Text, audio, or video posts, however close together they are published, are inherently serialized on the web in the order that they were submitted to the server. (ibid., emphasis mine)

Serialization as described by Buccitelli can be understood as a contribution to the discussion underlining the analytical import of communicative affordances with respect to technological media. Derived from an interaction between individual's subjective perception of utility and objective qualities of a technology - be that a paint brush or a cell phone - affordances refer to the fact that these technologies "afford certain communicative possibilities and not others" (Thurlow \& Mroczek 2011: xxiv; Schrock 2015; cf. Hutchby 2001). In other words, the communicative medium and its affordances are seen as having a reality of its own for interlocutors, irrespective of whether they consciously apprehend its effect or explicitly describe it. ${ }^{5}$

I would like to use Buccitelli's insight, which I think is valid and worth expanding on, as a jumping off point, elaborating on, and offering a few contributions to it. The aim is to demonstrate how an important portion of performative enactments in digital environments rely on emergent co-textual patterning that can be approached under the heading of poetics. When addressing poetics in aesthetically unmarked discourse, however, it is methodologically essential to realize that various poetic juxtapositions and affinities arise in digital and face-to-face environments all the time. There is always a veritable "surfeit of poetic patterns", an excess of possibly efficacious affinities and contrasts in communication, which have to be apprehended, restrained, and circumscribed in interaction for them to become socially meaningful (Lempert \& Fleming 2014). 
As folklorists, when speaking of performativity and performing, then, it becomes crucial to look into how these poetic patterns and the sort of small-scale reflexivity apparent in all interactions are calibrated and taken over socially by interactional agents. For whom do these poetic patterns actually decode as meaningful, performative effects, to what degree, and why? The last interrogative moreover points to how we simultaneously need to account for notions such as context and situation, participative agency, and efficacy, all crucial aspects of what is understood by performativity and performance (see also Pratt 1977 [1975]).

Ideally, one should also consider and compare the notions of performativity, performative enactments, and performances proper across all kinds of channels, modalities, textures, and means of communication available in digital environments (see also Buccitelli 2012: 79-80; Harper 2010: 6). For instance, it has been argued that identities in interactive social media, the so-called Web 2.0, are inexorably managed and thus performed. The same problematic is also brought forward by Buccitelli's (2012) anecdote opening his article, by which he recounts an incident in which his friend had deleted his Facebook account, as he felt the latter "forced" him to become a (narcissistic) performer of sorts. By my reckoning, the anecdote implicates that insofar as digital environments seem to omit explicit cues of keying and framing, it becomes essential to question how certain communicative platforms - for example, playfully oriented forums or, indeed, Facebook - might themselves foreground or coerce frames of performance, or otherwise elicit concerns of heightened performativity. They might achieve this by staging discrete texts as public expressions of seemingly authentic selves, which further take part in social practices of interpersonal evaluation and attention management: think of Facebook with its built-in devices for various affective reactions (see Paasonen 2016). Or, we might inquire into the potentials of more complex websites to perform in various ways: websites have several tactics at their disposal to perform in socially consequential manner, such as creative layout design, framing, etc. (see, e.g., Foley 2012; also Bogost 2010 on "visual rhetoric").

While such a full-scale comparative study is naturally beyond the scope of this text, I will supplement my initial focus on text-based digital interaction (SMS texting, instant messaging, etc.) with a second case that deals with what could be called visual poetics. What is more, I believe my general thesis regarding performative enactments is applicable for various other forms of digital communication, such as the use of emoticons, image memes, and hyperlinks, insofar as they are similarly functional in creating emergent effects in relation to their co(n)textual environments. Sequentially juxtaposed emoticons and image memes are, however, often even more ambiguous than verbalized messages, which means that their specific performative and pragmatic effects in various contexts might be more difficult to pin down (see also Milner 2013: 65). 


\section{TEXT-BASED DIGITAL ENVIRONMENTS}

Whereas the orientation of performance heralded an approach in folkloristics that laid the stress on entextualization, paralinguistics, and gestural dimensions of communicative enactments, a recurring topic in digital studies relates to how the significance of these dimensions of discursive interaction seems to have become diminished if not effaced in text-based environments. To say the least, the (somewhat limiting) affordance of communicating through the single channel of the visible writing system calls for a reconsideration of our epistemologies of performing. ${ }^{6}$ As mentioned, folkloristic studies on performing have been driven by the Baumanian spirit that regards performances as explicitly keyed as somehow distinct from other, unmarked communicative forms (see Bauman 1984 [1975]: 15-24, for conventional methods of keying in oral discourse). Needless to say, explicit keyings also occur in text-based digital environments. For instance, Tuija Virtanen (2013) has coined the term of "discourse transformers", by which she refers to discourse markers that signal shifts to different frames in digital discourse. Her specific focus is on "mock performatives" signaled by the formal marker hereby in text-based digital communication ("You are hereby banished from this kingdom!"), which she observes as typically initiating joint play sequences between interlocutors. However, whereas hereby as studied by Virtanen constitutes an explicit keying of playfulness, such explicit signals are often lacking in (digital) interaction.

To address the question of how we recognize performative enactments lacking explicit keying in text-based digital environments, I propose to turn to the potentials of implicit keying provided by poetic patterning. Poetic patterning is predicated as a highly productive constituent of performative enactments in digital environments insofar as the latter intrinsically self-organize around serialized, discrete units of utterance. In this regard, we should pay closer attention to the mutual match between poetics and text-based digital communication, because by necessity, for us to recognize the reflexively juxtaposed units responsible for poetic effects, we need certain formal instructions. What is needed, in particular, is some form of sequentiality of textual organization. And I suggest it is the cutting up of the otherwise linear discursive signal as a tendency of digital communication - serialization as per Buccitelli (2012) - that should be seen as functional in orienting us toward the poetic comparability of co-occurring, but not immediately contiguous, units in relation to each other and the whole textual event (Agha 1997: 469). 


\section{Poetics at Play in SMS Communication}

The first example that I would like to look at brings forward an instance of SMS text messaging in which the performativity of poetic patterning is implemented in everyday interaction by both interlocutors. Deborah Tannen (2013) provides this thought-provoking example of dyadic SMS texting event in her article on metamessages inherent to various communicative media, and analyses the case herself primarily from the perspective of formal stylization: the use of intensity markers and taciturnity. Tannen recounts an event provided to her by one of her students, in which Jackie and her friends gathered together in order to go somewhere. "As everyone in the group piled into taxis, only Jackie was left awaiting a last member of the group, who had been delayed." Left stranded by her friends, Jackie sent one of her departed friends in the taxis the text message represented in her first turn of dialogue (line 1). The following interactional sequence ensued (Tannen 2013: 108-109):

(1) 1

Jackie: Thanks for waiting for Melissa with me that's cool

2 Friend: JACKIE I AM SO SO SO SORRY! I thought you were behind us in the cab and then I saw you weren't!!!!!

I feel soooooooo bad! Catch another cab and ill pay for it for youuuuu

$3 \quad$ Jackie: no its fine we are walking

$4 \quad$ Friend: seriously Jackie please, get a cab, I feel so bad!!!

$5 \quad$ Jackie: we are walking there its fine

To summarize, Tannen (ibid.) describes how Jackie uses taciturnity to send a negative metamessage, that is, how her terse messages conspicuously lack any expressive markers, indicating how less than "fine" she really felt about the situation. On the other hand, Jackie's friend adopts various formal devices - expressive spelling, capitalization, repetition, reduplicated punctuation - to send a metamessage of affective intensity along with her explicit message of apology. ${ }^{7}$

To add to Tannen's analysis from the perspective that we have been elaborating on, we might note how SMS texting serializes singular messages and renders visible the sequentiality of textual organization for interlocutors on their mobile phones. ${ }^{8}$ To begin with, then, of importance is how Jackie initiates the interactional sequence by recourse to the expressive form of irony (line 1). Presumably provoked by disappointment, her mock-performative of thanking her friend for a (non-existent) act and predicating this course of action as "cool" is taken to implicate a negative comment on her friend's (lack of) considerateness. Her friend apprehends the ironic intention by apologizing intensely, explicating her (sincere or not) personal viewpoint on the preceding situation, 
denoting a negative affective state, which implicates a stance of regret, and by suggesting a correction to the dire situation.

Cues for poetic resonance appear in line 3. Propositionally speaking, Jackie's terse "no its fine we are walking" predicates an affective stance of neutrality, and a description of an (ongoing) course of action - it remains undecided whether her "fine" refers to the state of events or to her own affective stance. The stance of neutrality is corroborated by her laconic form of expression, as also noted by Tannen. On a superficial interpersonal level, Jackie thus notionally aligns herself with her interlocutor-friend. From a broader interactional perspective, however, things look different. Juxtaposed with the first, prominently ironic line, this third line is seen as resonating with it, and hence connoting, updating, and adding to the ironic effect: the overtone of neutrality is subordinated by an undertone of disappointment or displeasure with the chain of events.

Resonance is a concept used by sociolinguist John W. Du Bois, which he defines as "activated affinities across utterances or representations"; it is thus a property of relations between elements of discourse, not an isolatable attribute. Du Bois uses resonance as a complementary term for studying co-produced conversational discourse from the perspective of reproduction of utterance elements in general and poetic parallelisms in particular. Parallelism, for its part, can be designated as a type of recurrence or repetition with difference "in which parallel units are perceived as parallel members of groups" (Frog forthcoming; also Lindfors forthcoming). Thus, resonance creates relations between utterance elements, while parallelism is a product of producing such relations and thus a manifestation of the broader category of resonance (Du Bois 2014: 372-375). In order to map such reproduced elements, structures, and emergent resonances across utterances, Du Bois $(2007,2014)$ has developed a highly flexible "diagraph model" which allows one to organize dialogically juxtaposed utterance elements on a grid for visual rendering. In the present case, the diagraph (modeled after Du Bois 2014) can be deployed for bringing out the parallelism between Jackie's first two turns of dialogue (corresponding units of utterance are visually indicated by shading of the boxes):

(2)

\begin{tabular}{|c|c|c|c|}
\hline 1 Jackie: & Thanks for waiting for Melissa with me th & t 's cool & \\
\hline 3 Jackie: & no & 's fine & we are walking \\
\hline
\end{tabular}

Even though not salient between whole turns of dialogue, activated resonance and parallelism are here salient on the level of individual sentences. That is, in line 3, Jackie repeats her previous sentence "that's cool" with variation on the lexical surface (“it's fine"), producing the ironic effect identified earlier. Her second turn is dependent on the intermediate contrasting stance of her 
interlocutor, and thus simultaneously both responsive to her friend's apology and paralleling her own previous sentence. ${ }^{9}$

Revealingly, her friend is seen to recognize and apprehend this poetically produced and textually diffuse ironic effect in responding with an even more earnest plea ("seriously Jackie please"), which indicates that she has not bought Jackie's initial riposte represented in line 3 , but sensed more to be at play. The performativity of Jackie's poetic patterning is thus signaled, apprehended, and felt - there also seems to be a heightened engagement of participants in the situation (see Ling 2008, chapter 6).

What is more, the friend's two turns of dialogue in themselves manifest a form of resonance, rhetorical chiasmus to be specific, in which two units of utterance are repeated in an inverse sequence:

(3)

\begin{tabular}{|c|c|c|c|c|}
\hline 2 Friend: & $\cdots$ & I feel soooooooo bad! & Catch another cab & $\begin{array}{l}\text { and ill pay for } \\
\text { it for youuuuu }\end{array}$ \\
\hline 4 Friend: & $\begin{array}{l}\text { Seriously } \\
\text { Jackie please }\end{array}$ & get a cab & I feel so bad!!! & \\
\hline
\end{tabular}

Importantly in the sense that both interlocutors can be now observed as patterning their discourse poetically, not much new propositional information is produced: the conversation seems to have become somewhat stagnated in a standstill through repetitions and parallelisms on both sides. Performative and social tension, however, is still intact and very much felt. On top of this, Jackie's final response (line 5) constitutes yet another instance of salient resonance. By basically reproducing the exact same phrases as in line 3 - although in an inverse syntactical sequence, thus also exhibiting a rhetorical chiasmus Jackie further corroborates her stance of apparent neutrality and superficial alignment with her interlocutor. This chiasmus in turn resonates with, and may even be prompted by (see Sakita 2006 on emergent parallelism in syntax), her friend's chiasmus noted earlier, throwing into relief the pervasive intertwining of poetic resonance through the interactional sequence. The recurring ironic effect is again felt to be at play, the final turn of dialogue bringing home and settling the resolute nature of Jackie's disalignment with her friend in an even more conspicuously foregrounded fashion. By the end of the interactional sequence, Jackie is attributed a resolution of stance - perhaps a stance of firm disappointment. It could even be argued that, had she intended to convey sincere neutrality in line 5 , this intention is belied by the emergent, coercive pull of the actualized parallelism (cf. Glick 2012).

I would like to finally draw attention to how a bridge from poetic patterning in discourse to performative enactments can be built through the notion 
of metapragmatic effects. As Lempert \& Fleming (2014: 490) explain, poetic patterning "may come to guide an interpretation of what is being done in the text, of what acts people are doing, what roles people are inhabiting, what definition of the situation is in progress", and further note how such guidelines are typically the performative effect of metapragmatic iconicity (see also Silverstein 2004). To clarify, iconic resemblance between utterance elements in sequentially metricalized text - which is a semiotic way of framing parallelism - is understood as producing metapragmatic effects with regard to the communicative action at hand. In this case, the iconicity between units of utterance across three turns of dialogue produces the emergent metapragmatic effect of communicating the speaker's unyielding and resolute stance with regard to the preceding events. Jackie does not merely repeat with minor variations; her action is not merely a function of likeness or unlikeness between separate turns of dialogue. Rather, what is enacted through poetic iconicity is a cumulative effect or inference: the resolution of stance vis-à-vis her friend's apologies and appeals, or a "reluctance to let her friend off the hook", as Tannen (2013: 109) so aptly puts it. ${ }^{10}$ Iconic resemblance and repetition here have an all-encompassing effect on interpretations regarding action, participation roles, and definition of the situation. The point is, however, that the significance of this iconic pattern cannot be conflated with the significance of the utterances through which the iconic pattern is produced and achieved. Rather, poetic iconicity provides the grounds for comparison of utterance units, while comparison "in respect of what speakers say then serves as a principle for interpreting what speakers do" (Lempert \& Fleming 2014: 489).

I suggest it is preferable to term such communicative instances, in which the inherent performativity of poetic patterning is emphasized and deployed in (digital) discursive interaction, performative enactments. These enactments do not manifest a specific mode of communication, which would qualify them as performances proper in the sense that has been the tradition in folkloristics this tradition is, of course, somewhat expected because the focus in the latter has been primarily on specialized uses of language, such as verbal art, ritual speech, etc. That is, Jackie does not adopt a marked mode of performance, nor is she seen as claiming responsibility for specific communicative competence. Such enactments are, rather, events of communicative sign behavior that foreground and make use of the principle of performativity, for instance in the form of dialogic resonance, parallelisms, and metapragmatic iconicity, to enact and pursue distinct interactional outcomes. Performative enactments are, moreover, typically achieved cumulatively, for instance, over several turns-of-talk, which means that researchers should accordingly pay closer attention to the provisional and cumulative nature of such enactments in interaction (Lempert 
\& Fleming 2014: 492). Insofar as these enactments are apprehended and thus only efficient in acts of interpretative construal, it is always possible for the interactional agents responsible for interpretative acts to "get" them only partially, or, to get them in completely different ways. This is something that has to be kept in mind when theorizing poetically produced performativity online, which re-emerges with our second case in an illustrative manner.

\section{VISUAL WEB DESIGN AS PERFORMATIVE ENACTMENT: THE PER-LOOKS MEDIA EVENT IN FINLAND}

The second example that I would like to present concerns a case in which a visually oriented website - albeit a simple one - is understood as implementing performative effects. I am referring to the so-called Per-Looks media event that took place in the Finnish media over a few days of October 2012 and quickly generated a surge of heated online debate. Per-Looks is a website, still available online for the reader to see (that is, in November 2016), which is simply comprised of its eponymous logo in the top corner, rows and columns of photographic portraits of the Finns Party municipal election candidates, and pretty much nothing else (formerly known as the True Finns - "Perussuomalaiset" in Finnish; the title Per-Looks is thus derived, to be clear, from the first three letters of the party's Finnish name). This photographic gallery was uploaded and introduced on the social photograph-sharing media Tumblr on the 7th of October 2012, and maintained its status as a hot topic in the Finnish media spotlights for a few days before vanishing into oblivion. The site gave rise to columns, news articles, blog texts, Facebook debates, and forum discussions across party lines, a lion's share of which focused on the site's putative meanings, functions, implications, tastefulness, etc. Heated debate took place due to the fact that even though the website itself presented itself as conspicuously and seemingly neutral, a strong line of interpretation took it as maliciously intentioned mockery targeting the habitus of the Finns Party candidates, which was further associated with the lower class.

As background information regarding the debate around Per-Looks, it should be pointed out that one salient divide in the Finnish social and political climate - even more so after the general elections of 2015 - is situated between the ("Green-Left") liberal urban and the conservative provincial social fraction, the latter of which is prominently represented by the Finns Party. The efficacy of the Per-Looks website was related to the fact that it struck the Finnish social and political imagination by juxtaposing and conflating these two opposing (very coarsely speaking, of course) social and political fractions, identities, 
and habitus. It also bears mentioning that similar galleries of the candidates of other Finnish political parties quickly emerged after the Per-Looks event. However, none of these derivations garnered as much (negative) attention from the public as the original.

I want to clarify at the outset that my intention here is not to (moralistically) address the issue of whether the website was distasteful or not, nor whether it manifested a stable "message" that could be potentially peeled out by supposedly authoritative analytics: these were the issues interlocutors themselves in various online forums contested vigorously. Rather, by treading the path laid out in previous chapters, I aim to outline an analytic perspective to the website as (an ambiguous) performative enactment dependent on poetic patterning. After all, the Per-Looks website was interpreted by commentators and interlocutors as first and foremost performing socially, most prominently as enacting insult. It was not regarded as visually representing the candidates as if representation could ever be neutral or stable in a semiotic sense: this much is proven, by my reckoning, by the empirical fact that people were offended by the website. By commencing from this basic observation, I intend to show how the performative aspects of the website were a function of its poetic design - again, understood as formal patterning that reflexively draws attention to co-present similarities and differences by juxtaposition.

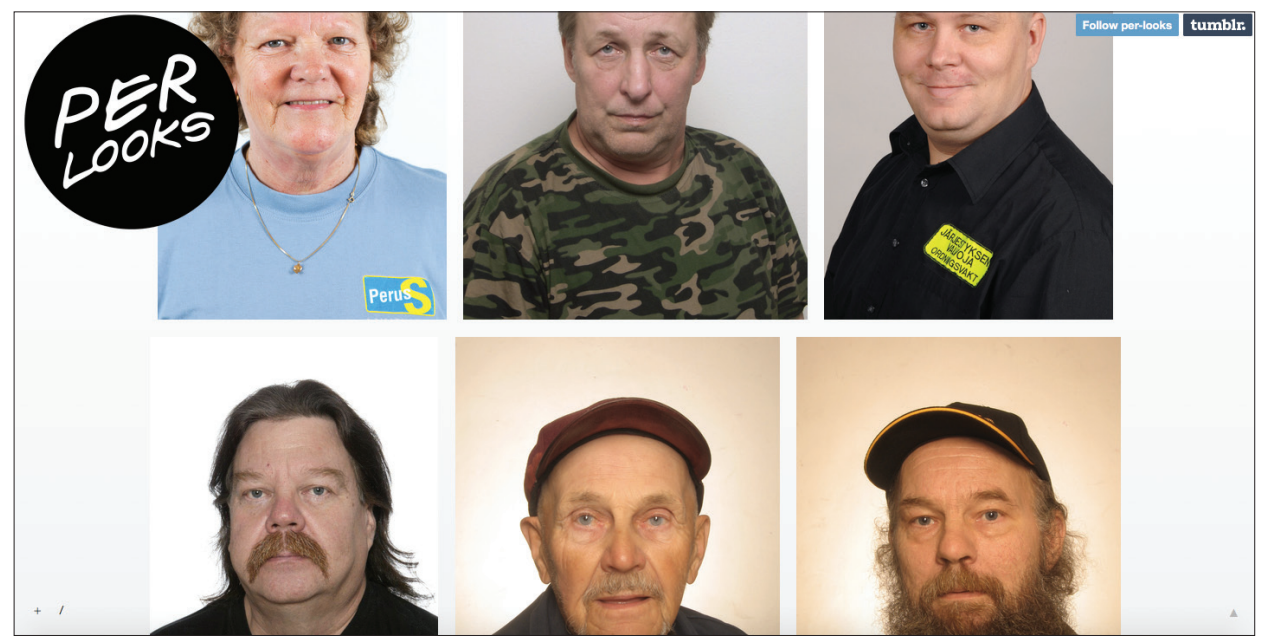

Figure 1. Screenshot of the Per-Looks website (http://per-looks.tumblr.com/). 
As said, the website is a simple gallery comprised of a selection of photographic portraits of the populist Finns Party candidates for the 2012 municipal elections (see Fig. 1). While the images themselves are official promotional photographs of the said political party, echoing similar galleries usually seen on sidewalks before elections, they are collated side-by-side, row after row, without captions or any verbal commentary whatsoever. That is, the webpage is deliberately designed so as to abstain from prescriptive metacommentary, from commenting on the intentions and aims motivating the website or the actual display of the photographs. However, such "conceit of neutrality" (Walton \& Jaffe 2011) is belied by the singular and most prominent contextualization cue of the site: the title of the gallery. The title Per-Looks is phrased after the popular website Hel-Looks, a style and fashion site documenting the latest street fashion of Helsinki (http://www.hel-looks.com/). In addition to the verbal pun itself, this imitative intention is brought home by the visual design of the logo, likewise reminiscent and modelled after the Hel-Looks logo. The gallery thus exhibits explicit "recipient design" (Sacks \& Schegloff \& Jefferson 1974), a purposive steering of attention to the differential between the source (Hel-Looks) and the target (Per-Looks) (see Lempert 2014).

Further implications emerge out of these objective features of the website. As an imitation or parody of Hel-Looks, outer appearance, style, fashion, and taste ("-Looks") are foregrounded in the portraits of the candidates as dominant orienting frames. Indeed, the political candidates are individualized according to the tradition of portraiture, a genre of visual discourse that in itself can be seen as reflecting an indelible interest in the articulation of human variety. For instance, Mieke Bal notes how portraiture foregrounds individuality in an inherently contrastive framework, because "it also provides tools with which to speak of the sameness in difference and the difference in sameness, both at once" (Bal 2002: 229). Further still, insofar as the photographs are collated on the website after what must have been a process of deliberate selection perhaps hand-picked out of hundreds of potential choices - the representation of the candidates does not seem random but more reasonably construed as following certain logic. Rather than trying to evaluate here the motivations of this logic, I find it preferable to turn to the public interpretations that the website gave rise to.

The imitative nature of Per-Looks was widely recognized in the ensuing reactive commentary in the (social) media. It also seemed as though an ironic or mocking intent was attributed to the website by most commentators - however, the explicit terms of humor, parody, irony, and sarcasm were, not unexpectedly, used rather loosely and impressionistically. In a representative news article, the motivating purpose of the gallery was regarded as "most probably to joke 
around to the detriment of the candidates of the Finns Party", even though the parodying intent that supposedly also targeted the Hel-Looks brand was simultaneously recognized (see Uusi Suomi 2012). ${ }^{11}$ In other words, the target and the implications of this ironic mocking emerged as a focal bone of contestation from which other deductions followed. One line of interpretation suggested how the outer appearance of the Finns Party candidates as portrayed by Per-Looks was a positive one, notwithstanding the (possibly malicious) motivations of its author. This viewpoint was crystallized, for example, in the following comment:

Whatever the mischievous author of the Tumblr had intentioned when compiling his collection, he has unintentionally created a catalogue that is productive in arousing sympathies towards the Finns Party. Through these various faces the party gives off just the kinds of mental images that they presumably want to give: ordinariness and unaffectedness. [...] the authenticity and humanity of these common candidates shines through the photographs spontaneously. ${ }^{12}$

Of course, parody and other forms of deliberately ambiguous expression are distinct in that they are structured so as to obscure precisely these aspects of communication. They can appear as manifesting a seemingly "neutral" stance, or, better yet, juxtaposing, superimposing, and playing with several stances, simultaneously indexing multiplicities of both stances and audiences. And by indexing multiple stances, all of those stances are rendered potentially available to be claimed after the fact by the stance-taker (Jaffe 2009: 18).

For the purposes of the present article, I want to draw attention to how the website was understood and claimed as issuing a generalization of social types. To borrow from recent studies on semiotic registers, the gallery was construed as enregistering a specific "Finns Party register", in the sense of a certain model of personhood, which in this case articulated a political fraction with (negative) associations of style, fashion, taste, and habitus. ${ }^{13}$ Even though I will sidestep any attempt at a detailed analysis of the specific diacritics of appearance, taste, or habitus of Per-Looks in the following, it is obvious that these visual diacritics were ultimately also perceived as emblematic of lower social class (see Helsingin Sanomat 2012).

Enregisterment here refers to the process by which semiotic registers are metasemiotically formed, while registers' repertoires have to be understood as comprising a full range of semiotic modalities, "signs in any phenomenal channel of perceivable conduct" (Agha 2011: 26; Agha 2007; Agha \& Frog 2015). As Frog explains, "rather than being restricted to resources and conventions appropriate to certain situations of linguistic behavior, a register can be viewed more comprehensively as resources constitutive of cultural 'models of action", 
including resources such as outer appearance, habitus, taste, behavior, etc. (Frog 2014: 199, citing Agha 2007: 81). What was more, the Per-Looks website was construed as indexing this register in both senses of the word, entailing and presupposing, the latter of which was presumably more socially efficacious (e.g. offensive). In other words, it gave rise to and entailed the object as well as insinuated about the factual existence of this supposedly known social type.

Enregisterment can be analyzed as a general process that precipitates over a longer sequence of time (Agha 2007, chapter 4), but also as an enactment of briefer temporal span (e.g. Johnstone 2011). In this case, it is fruitful to approach it through the notion of enactment that can be analyzed from the perspectives of both the website and of secondary interpretative construal. In the following, I will concentrate on the former. I suggest the website accomplishes the enregisterment of a social type by framing itself as a fashion gallery, but also by its formally poetic features that foreground co-present similarities and differences through parallelism.

Perhaps most important of these features is how the website lays the individual photographs in serialized rows, the number of photographs in which varies, though, in relation to the size of the browser window as well as in relation to the width of the photographs (not all of them are of the exact same size). The photographs are formally and thematically comparable: they depict persons in frontal portraits and headshots. Given the basic presumption that the website is approached as an entextualized whole, constituted of distinguishable units of meaningful expression (photographic images), this patterning has the effect of formatting the presentation so that the parallelism between individual photographs becomes highly salient. To borrow from Jakobson's (1960) seminal formulation of poetics, we can say that the website accomplishes a shift of focus onto the level of sequential positioning within a compositional whole, or alternatively that the text exhibits a high level of diagrammatic motivation (see Lempert 2008: 573). Parallelism articulates a mapping between dialogically juxtaposed units of expression with the consequence that the photographs are interpreted as iconically similar and indexing each other: they become comparable vis-à-vis their mutual (proposed) likeness and unlikeness. In this case, the dominant reference frame of Hel-Looks is of primary significance with regard to which features of the photographs come into focus in considerations of likeness and unlikeness. This frame structures the reception of Per-Looks by correlating the series of photographs of political candidates with representations of style, taste, or fashion.

In sum, the efficacy of Per-Looks as performative enactment derives from the saturated parallelism of formally and thematically comparable visual units subsumed under the dominant reference frame of "looks". The website manifests 
indexical iconicity between serialized images, which reflexively draws attention to its own form and content and gives rise to a higher-level (interpretative) process that I have here captured with the semiotic notion of enregisterment. Enregisterment thus refers to how the diacritics of appearance, style, and taste are made to appear as indexically congruent, as indexing a stable model of personhood and an emblem of social class, while congruence here is a function of poetic parallelism. However, while the correlation of titles of Per-Looks (as the target) and Hel-Looks (as the source and reference frame) provides the recipients with the most obvious instructions to approach the photographs as representations of style or fashion, the precise communicative action accomplished by the website is never explicitly described or referred to. Rather, the reflexive function associated with parallelism serves as a principle for the construal of meaningful communication, and can be, again, conceptualized through metapragmatic iconicity (Lempert 2008: 573). This ambiguous enactment was then interpreted through a diverse scale as pejorative "mockery", "parody", etc., by acts of attribution from the interpreters' part.

As a final point regarding the ambiguous nature of poetically accomplished performative enactments, it is worth noting how the reception of these enactments can be revealing with regard to the recipients (interpreters) themselves. Accordingly, Per-Looks was also understood as functioning in the way of a Rorschach test for the society to reveal its ideological assumptions in the nexus of different political parties, classes, and appearances. In the words of an online commenter: "In addition to that (probably by accident) it [Per-Looks website] is quite an ingenious mirror; You can say quite a lot about a person by looking at how he or she reacts to it - especially if you can compare it with some precedent." 14 The commenter here recognizes and explicates one of the characteristic features of poetically accomplished performative enactments: the nature of their effects as emergent and ephemeral projections that can be perfectly functional and justifiable in determinate contexts but that remain fundamentally contestable.

\section{FROM SERIALIZATION TO PERFORMATIVE ENACTMENTS}

In this article, I have laid out an approach to performative enactments in digital environments useful for both linguistic anthropologists and folklorists alike. Just as poetics has been deemed ubiquitous if fleeting in discursive interaction, I suggest folklorists interested in performances and performative enactments in digital environments have to orient themselves to the more general performativity that is emergent and empirically retraceable in everyday digital 
interaction (see also Buccitelli 2012: 68). The larger argument of my paper, then, relates to the fact that poetically accomplished performative enactments may be much more frequent and commonplace than we perhaps might have at first thought (this point is also stated through parallelism in Glick 2012). This might be increasingly relevant, given the one-dimensional monomodality and the foregrounded materiality of technologically mediated (textual) communication. After all, performing does not have to be multimodally intricate, instantly and unequivocally recognizable, or explicitly keyed.

First, I analyzed a sequence of SMS text messaging between two friends (provided by Tannen 2013) and showed how the dialogically resonant patterning of both interlocutors comes to convey metapragmatic effects through iconicity. In this way, performative enactments might be said to deploy poetic patterning to do something more, to give rise to various inferences and effects by constructing metapragmatic icons (Lempert \& Fleming 2014: 490). While listing a full inventory of such metapragmatic icons could prove futile or impossible in the abstract, it remains an important task for folklorists and linguistic anthropologists to analyze the functions of these moves in concrete ethnographic settings and contexts. Another point of the analysis was to demonstrate that the strictly propositional level of the text - the referring and the predicating played out in each separate utterance - constitutes only a fraction, albeit in a sense the backbone, of interaction. This level is most conspicuous to overt inspection, especially in text-based digital environments, which render the propositional text overtly visible as durable, material trace. However, it gets us only so far with regard to the complete interactive dynamics in general, as well as to performativity in particular.

Secondly, I presented the case of the Per-Looks media event that took place in Finland some years ago. My intention with this case was to show how poetics and performativity as communicative principles can be operationalized as valuable tools to also approach visual discourse and web design. I argued how the formal and thematic parallelism articulated between individual portraits on the website, along with its conspicuous title, implemented a semiotic process called enregisterment, in which a specific cultural model of personhood emerged. In short, the website reframed the original election photographs into a textual configuration that came to foreground the visual diacritics of appearance, fashion, taste, and habitus as social indexicals of a supposed type. Again, the performative enactment was seen as an outcome of the reflexive patterning of units of meaningful expression within an entextualized whole, i.e., the website. The uptake of this implicit enactment was then vigorously contested in diverse, and highly revealing, interpretations by various commenters. Performative 
enactments have the power to elicit participative engagement of their recipients, to draw them in (cf. Collins 2004 on what he calls "entrainment"). The recipient, in recognizing an enactment, typically signals apprehension of the said enactment by reacting to it, which was also seen in both of the examples. Such reactions often constitute the most visible or perceivable semiotic proof of the effect of performative enactments.

The so-called mobile society of the twenty-first century has been seen as implementing fundamental changes in the way we keep in touch with each other, express ourselves, as well as form and sustain communities across places and times. According to certain commenters, there has been a veritable shift "from fixed geographies of sociality to dynamic spatial flows of human interaction" (Harper 2010: 113). Be that as it may, Danet (2005), amongst others (e.g. Couldry 2003), has shown how with some provisos and adaption, tried and tested ethnographic methods are still appropriate for studying mediated, performative, and ritualized interaction online. This sanguine hypothesis has also served as the guiding star for the present article, and I believe it will continue to provide digital scholars with an ethnographic bent with plenty of work in the future.

\section{ACKNOWLEDGEMENTS}

The first draft of this paper was prepared for the Folklore Fellows' Summer School held in Seili, Nauvo, in June 2015. Besides the participants of the Summer School and anonymous reviewers provided by the journal Folklore: Electronic Journal of Folklore, I would like to thank Mr. Frog from the University of Helsinki for crucial help with a later draft of this paper.

\section{NOTES}

1 Bearing these distinctions in mind, it is curious how normatively Don Kulick (2003), linguistic anthropologist himself, wants to deny performativity the status of a linguistic concept on the fact that it originally emerged in philosophy. By his estimate, linguistic anthropology has mostly studied various performances, not performativity. For Kulick (2003: 140), "performance is something a subject does. Performativity, on the other hand, is the process through which the subject emerges (Butler 1993: 2, 7, 95)." In aligning himself with what I have termed the perspective of cultural theory, Kulick's exclusive formulation that focuses on the emergence of subjectivity tends to dismiss crucial work in linguistic anthropology, where the significance of performativity has to be understood as something like "causal efficacy of signs in society" (Lempert \& Fleming 2014: 495). 
2 Interestingly, Maria Schwertl (2016) has recently proposed "enactment" as an intermediary term between the notions of performance and practice, the former of which is primarily associated with American folkloristics, and the latter with European ethnology. For Schwertl (2016: 173), enactment offers sensitivity towards both "the usual activity" (habitual practice) and "the something that will perhaps matter" (emergent performance). For a classic discussion of enactments in folklore studies, see Abrahams 1977.

3 Granted, Judith Butler (1990: 44, 89; also Butler 1997: 21, 44) already approached performativity through the notion of enactment, for instance, by defining sex as "a performatively enacted signification" and gender "as an enactment that performatively constitutes the appearance of its own interior fixity" (see also Schwertl 2016: 174, footnote 3). My approach differs from hers in conceptualizing the performative aspect of language use through its specific implementation through poetics, to be elaborated below.

${ }^{4}$ Although emphasized in emic genres specifically designated as "poetic", the poetic function has generally been regarded as, if not too frequently demonstrated to be, a pervasive feature of all discourse (Banti \& Giannattasio 2004; for a detailed case of conversational poetics, see Glick 2012). By my reckoning, the abstract principle of poetics is thus to specific genres of poetries as performativity is to specific performances. That is to say, poetics and performativity are the necessary principles of poetries and performances, while the latter implement and make use of the former in specific, socioculturally and historically contingent ways (see also Lempert \& Fleming 2014: 505 , footnote 3 ).

5 The notion of affordances could be productively interrogated with the idea of metamessages inherent to different media platforms (Tannen 2013). For instance, on some occasions the fact that you will phone your friend instead of texting him or her carries significant implicit meaning in itself, just as writing a letter vs. typing it carried similar connotations some decades ago. The values attached to different technological media have to be further understood as inter-generational and -cultural phenomena (see also Höflich \& Gebhardt 2006).

6 On the other hand, monomodality of text-based environments can be argued as turning the participants' attention specifically to the verbal means of their interaction by reducing the transparency of their communicative means (e.g. Georgakopoulou 2003). Interestingly, such metalinguistic foregrounding has also been suggested as highlighting the import of explicit metadiscourse and as encouraging verbal play such as figurative language use and various voicing phenomena. Georgakopoulou (2003) further interprets it as encouraging the putting on of various personae (see also Danet 2001; Kramer 2011: 140-141).

7 It might be illuminating to note here that insofar as texting is relatively cumbersome and time-consuming, tendencies and strategies to save time, effort, and space are frequently observed in SMS messaging, as are immediacy and informality of style. Furthermore, SMS "messages are addressed to specific individuals with a high degree of personal disclosure", which means that SMS messengers typically have a high degree of insight into each other's lives and personas (Hård af Segerstad 2006: 35). 
8 It was of course Tannen herself (2007 [1989]; see also Lempert 2008: 572), who originally took issue with identifying and demonstrating the poetic qualities of conversational discourse, and my intention is not to contest or disqualify Tannen's own analysis regarding this sequence of SMS interaction by any means.

9 The stance of apparent neutrality that she maintains vis-à-vis the unfortunate event of abandonment and her friend by the parallelism - and against which her friend also positions herself, although contrastively - could be also described through the notion of deixis (see Frog forthcoming for a discussion of deixis in relation to parallelism).

10 To borrow Tannen some more from her seminal work on repetition in conversational discourse, repetition foregrounds and intensifies the part repeated, while also paradoxically foregrounding and intensifying the part that is different (2007 [1989]: 60-61). To repeat is rarely just a repetition of the same; rather, the audience "reinterprets the meaning of the word or phrase in light of the accretion, juxtaposition, or expansion" (ibid.: 62). Here, what is different is a function of the cumulative effect itself.

${ }^{11}$ In a one-of-a-kind interview, the author of the gallery, graphic artist Juha Leinonen, was referenced as saying how the intention behind the website was precisely to mock the original website Hel-Looks and the "cultures of posing and showing off" it is alleged as representing. According to him, the page did not further any political agenda (see Helsingin Sanomat 2012). The case illustrates particularly poignantly how speakers in general have "contextually variable access to and authority over the illocutionary force of their own utterances" (Duranti 2015: 4).

12 Original in Finnish: "Mitä sitten lieneekään pilkkamielinen tumblrintekijä ajatellut kokoelmaansa laatiessaan, hän on tahtomattaan tullut luoneeksi kuvaston joka on omiaan herättämään sympatiaa perussuomalaisia kohtaan. Näiden kaikenlaisten kasvojen kautta puolue antaa itsestään juuri sellaisia mielikuvia joita todennäköisesti haluaisikin antaa: kansanomaisuutta ja teeskentelemättömyyttä. [...] näiden riviehdokkaiden aitous ja ihmisyys paistavat kuvista välittöminä” (see Harran 2012).

${ }^{13}$ Put differently, the Per-Looks website rendered the election photographs into commodity formulations. Commodity formulations foreground certain products or objects clothing, outer appearance, etc. - as social indexicals, "as objects whose use indexes attributes of users that differentiates them from others within frameworks of social classification" (Agha 2011: 24).

${ }^{14}$ Original in Finnish: "Sen lisäksi se (todennäköisesti vahingossa) on varsin näppärä peili; Voit kertoa ihmisestä aika paljon sen perusteella, miten hän reagoi siihen etenkin jos voit verrata sitä johonkin aikaisempaan" (see comment \#3 in Harran 2012). 


\section{REFERENCES}

Abrahams, Roger D. 1977. Toward an Enactment-Centered Theory of Folklore. In: William R. Bascom (ed.) Frontiers of Folklore. Boulder, CO: published by Westview Press for the American Association for the Advancement of Science, pp. 79-120.

Agha, Asif 1997. Tropic Aggression in the Clinton-Dole Presidential Debate. Pragmatics, Vol. 7, No. 4, pp. 461-497. Available at http://journals.linguisticsociety.org/ elanguage/pragmatics/article/download/252/252-537-1-PB.pdf, last accessed on June 30, 2017.

Agha, Asif 2007. Language and Social Relations. Cambridge: Cambridge University Press.

Agha, Asif 2011. Commodity Registers. Journal of Linguistic Anthropology, Vol. 21, No. 1, pp. 22-53. http://dx.doi.org/10.1111/j.1548-1395.2011.01081.x.

Agha, Asif \& Frog (eds.) 2015. Registers of Communication. Helsinki: Finnish Literature Society.

Austin, John L. 1962. How to Do Things with Words. Edited by J. O. Urmson. London: Clarendon Press.

Bal, Mieke 2002. Travelling Concepts in the Humanities: A Rough Guide. Toronto: University of Toronto Press.

Banti, Georgio \& Giannattasio, Francesco 2004. Poetry. In: Alessandro Duranti (ed.) A Companion to Linguistic Anthropology. Malden, MA: Blackwell, pp. 290-320.

Barad, Karen 2007. Meeting the Universe Halfway: Quantum Physics and the Entanglement of Matter and Meaning. Durham \& London: Duke University Press.

Bauman, Richard 1984 [1975]. Verbal Art as Performance. With supplementary essays by Barbara A. Babcock [and others]. Prospect Heights, Ill.: Waveland Press.

Bauman, Richard 2012. Performance. In: Regina F. Bendix \& Galit Hasan-Rokem (eds.) A Companion to Folklore. Malden: Wiley-Blackwell, pp. 94-118.

Bogost, Ian 2010. Persuasive Games: The Expressive Power of Videogames. Cambridge: MIT Press.

Bronner, Simon J. 2012. Practice Theory in Folklore and Folklife Studies. Folklore, Vol. 123, No. 1, pp. 23-47. http://dx.doi.org/10.1080/0015587X.2012.642985.

Buccitelli, Anthony Bak 2012. Performance 2.0: Observations Toward a Theory of the Digital Performance of Folklore. In: Trevor J. Black (ed.) Folk Culture in the Digital Age: The Emergent Dynamics of Human Interaction. Boulder, CO: Utah State University Press, pp. 60-84.

Butler, Judith 1990. Gender Trouble: Feminism and the Subversion of Identity. New York: Routledge.

Butler, Judith 1993. Bodies That Matter: On the Discursive Limits of "Sex". New York \& London: Routledge.

Butler, Judith 1997. Excitable Speech: A Politics of the Performative. New York \& London: Routledge.

Collins, Randall 2004. Interaction Ritual Chains. Princeton, NJ: Princeton University Press.

Couldry, Nick 2003. Media Rituals: A Critical Approach. London \& New York: Routledge. 
Danet, Brenda 2001. Cyberpl@y: Communicating Online. Oxford: Berg.

Danet, Brenda 2005. Ritualized Play, Art, and Communication on Internet Relay Chat. In: Eric W. Rothenbuhler \& Mihai Coman (eds.) Media Anthropology. Thousand Oaks, CA: SAGE, pp. 229-246.

Du Bois, John W. 2007. The Stance Triangle. In: Robert Englebretson (ed.) Stancetaking in Discourse: Subjectivity, Evaluation, Interaction. Philadelphia: John Benjamins, pp. 139-182.

Du Bois, John W. 2014. Towards a Dialogic Syntax. Cognitive Linguistics, Vol. 25, No. 3, pp. 359-410. http://dx.doi.org/10.1515/cog-2014-0024.

Duranti, Alessandro 2004. Agency in Language. In: Alessandro Duranti (ed.) A Companion to Linguistic Anthropology. Malden, MA: Blackwell, pp. 451-473.

Duranti, Alessandro 2015. The Anthropology of Intentions: Language in a World of Others. Cambridge: Cambridge University Press.

Fischer-Lichte, Erika 2008. The Transformative Power of Performance: A New Aesthetics. Transl. by Saskya Iris Jain. London: Routledge.

Foley, John Miles 2012. Oral Tradition and the Internet: Pathways of the Mind. Urbana: University of Illinois Press.

Frog 2014. Parallelism, Mode, Medium, and Orders of Representation. In: Frog (ed.) Parallelism in Verbal Art and Performance. Pre-Print Papers of the SeminarWorkshop, 26th-27th May 2014, Helsinki, Finland. Helsinki: Folklore Studies, University of Helsinki, pp. 185-207.

Frog (forthcoming). Parallelism and Orders of Signification (Parallelism Dynamics I). Oral Tradition.

Georgakopoulou, Alexandra 2003. Computer-Mediated Communication. In: Jef Verschueren \& Jan-Ola Östman \& Jan Blommaert \& Chris Bulcaen (eds.) Handbook of Pragmatics. Amsterdam \& Philadelphia: John Benjamins.

Glick, Douglas J. 2012. Language Contextualization in a Hebrew Language Television Interview: Lessons from a Semiotic Return to Context. Semiotica, Vol. 192, pp. 341-380. http://dx.doi.org/10.1515/sem-2012-0070.

Hård af Segerstad, Ylva 2006. Language in SMS - A Socio-Linguistic View. In: R. Harper \& L. Palen \& A. Taylor (eds.) The Inside Text: Social, Cultural, and Design Perspectives on SMS. Dordrecht: Springer, pp. 33-51. Available at http://www.springer. com/gp/book/9781402030598, last accessed on June 30, 2017.

Harper, Richard H. R. 2010. Texture: Human Expression in the Age of Communications Overload. Cambridge, Massachusetts: The MIT Press.

Harran, Anis 2012. Perluukkikausti. Uusi Suomi, October 8. Available at http://harran. puheenvuoro.uusisuomi.fi/119854-perluukkikausti, last accessed on June 30, 2017.

Helsingin Sanomat 2012 = Professori: Per Looks -kohun taustalla kysymys luokkayhteiskunnasta. [Professor: The Question of Class Society Lies behind the Commotion on Per Looks.] Helsingin Sanomat, October 10. Available at http://www. hs.fi/kulttuuri/a1305605600646, last accessed on June 30, 2017. 
Höflich, Joachim R. \& Gebhardt, Julian 2006. Changing Cultures of Written Communication: Letter - E-mail - SMS. In: R. Harper \& L. Palen \& A. Taylor (eds.) The Inside Text: Social, Cultural, and Design Perspectives on SMS. Dordrecht: Springer, pp. 9-31. Available at http://www.springer.com/gp/book/9781402030598, last accessed on June 30, 2017.

Hutchby, Ian 2001. Technologies, Texts, and Affordances. Sociology, Vol. 35, No. 2, pp. 441-456. http://dx.doi.org/10.1177/S0038038501000219.

Jaffe, Alexandra 2009. Introduction: The Sociolinguistics of Stance. In: Alexandra Jaffe (ed.) Stance: Sociolinguistic Perspectives. Oxford \& New York: Oxford University Press, pp. 3-28.

Jakobson, Roman 1960. Closing Statement: Linguistics and Poetics. In: Thomas A. Sebeok (ed.) Style in Language. Cambridge, MA: MIT Press, pp. 350-377.

Johnstone, Barbara 2011. Dialect Enregisterment in Performance. Journal of Sociolinguistics, Vol. 15, No. 5, pp. 657-679. DOI: 10.1111/j.1467-9841.2011.00512.x.

Kirschenblatt-Gimblett, Barbara 1996. The Electronic Vernacular. In: George E. Marcus (ed.) Connected: Engagements with Media. Chicago \& London: University of Chicago Press, pp. 21-66.

Kramer, Elise 2011. The Playful Is Political: The Metapragmatics of Internet RapeJoke Arguments. Language in Society, Vol. 40, No. 2, pp. 137-168. http://dx.doi. org/10.1017/S0047404511000017.

Kulick, Don 2003. No. Language \& Communication, Vol. 23, No. 2, pp. 139-151. Available at http://www.sciencedirect.com/science/journal/02715309/23/2, last accessed on June 30, 2017.

Lempert, Michael 2008. The Poetics of Stance: Text-Metricality, Epistemicity, Interaction. Language in Society, Vol. 37, No. 4, pp. 569-592. http://dx.doi.org/10.1017/ S0047404508080779.

Lempert, Michael 2014. Imitation. Annual Review of Anthropology, Vol. 43, No. 1, pp. 379-395. http://dx.doi.org/10.1146/annurev-anthro-102313-030008.

Lempert, Michael \& Fleming, Luke 2014. Poetics and Performativity. In: N. J. Enfield \& Paul Kockelman \& Jack Sidnell (eds.) The Cambridge Handbook of Linguistic Anthropology. Cambridge: Cambridge University Press, pp. 485-515.

Lindfors, Antti (forthcoming). Twin Constellations: Parallelism and Stance in Stand-Up Comedy. Oral Tradition.

Ling, Richard 2008. New Tech, New Ties: How Mobile Communication is Reshaping Social Cohesion. Cambridge, MA: The MIT Press.

Lloyd, Moya 1999. Performativity, Parody, Politics. In: Vikki Bell (ed.) Performativity and Belonging. London: SAGE, pp. 195-213.

Milner, Ryan M. 2013. Hacking the Social: Internet Memes, Identity Antagonism, and the Logic of the Lulz. The Fibreculture Journal, Vol. 22. Available at http:// twentytwo.fibreculturejournal.org/fcj-156-hacking-the-social-internet-memesidentity-antagonism-and-the-logic-of-lulz/, last accessed on July 3, 2017.

Paasonen, Susanna 2016. Fickle Focus: Distraction, Affect, and the Production of Value in Social Media. First Monday, Vol. 21, No. 10. http://dx.doi.org/10.5210/ fm.v21i10.6949. 
Pratt, Mary Louise 1977 [1975]. Toward a Speech Act Theory of Literary Discourse. Bloomington: Indiana University Press.

Pressman, Jon F. 1994. Pragmatics in the Late Twentieth Century: Countering Recent Historiographic Neglect. Pragmatics, Vol. 4, No. 4, pp. 461-489. http://dx.doi. org/10.1075/prag.4.4.06pre.

Sacks, Harvey \& Schegloff, Emanuel A. \& Jefferson, Gail 1974. A Simplest Systematics for the Organization of Turn-Taking for Conversation. Language, Vol. 50, No. 4, pp. 696-735. http://dx.doi.org/10.1353/lan.1974.0010.

Sakita, Tomoko I. 2006. Parallelism in Conversation: Resonance, Schematization, and Extension from the Perspective of Dialogic Syntax and Cognitive Linguistics. Pragmatics and Cognition, Vol. 14, No. 3, pp. 467-500. http://dx.doi.org/10.1075/ pc.14.3.03sak.

Schrock, Andrew Richard 2015. Communicative Affordances of Mobile Media: Portability, Availability, Locatability, and Multimediality. International Journal of Communication, Vol. 9, pp. 1229-1246. Available at http://ijoc.org/index.php/ ijoc/article/view/3288, last accessed on July 3, 2017.

Schwertl, Maria 2016. Response: “We have a situation here!”: On Enactment as a Middle Ground Between Practice and Performance. Cultural Analysis, Vol. 15, No. 1, pp. 168-177. Available at http://socrates.berkeley.edu/ caforum/volume15/vol15_ schwertl.html, last accessed on July 3, 2017.

Silverstein, Michael 2004. "Cultural" Concepts and the Language-Culture Nexus. Current Anthropology, Vol. 45, No. 5, pp. 621-652. http://dx.doi.org/10.1086/423971.

Tannen, Deborah 2007 [1989]. Talking Voices: Repetition, Dialogue, and Imagery in Conversational Discourse. Second Edition. New York: Cambridge University Press.

Tannen, Deborah 2013. The Medium is the Metamessage: Conversational Style in New Media Interaction. In: Deborah Tannen \& Anna Marie Trester (eds.) Discourse 2.0: Language and New Media. Washington, DC: Georgetown University Press, pp. 99-118.

Thurlow, Crispin \& Mroczek, Kristine 2011. Introduction: Fresh Perspectives on New Media Sociolinguistics. In: Crispin Thurlow \& Kristine Mroczek (eds.) Digital Discourse: Language in the New Media. New York: Oxford University Press, pp. xix-xliv.

Uusi Soumi 2012 = Netti-ilmiö hassuttelee perussuomalaisilla: "Katso silmiin". [WebBased Phenomenon Making a Fuss in Finnish: "Look in Your Eyes".] Uusi Suomi, October 7. Available at http://www.uusisuomi.fi/kotimaa/54016-netti-ilmiohassuttelee-perussuomalaisilla-katso-silmiin, last accessed on June 30, 2017.

Virtanen, Tuija 2013. Mock Performatives in Online Discussion Boards. Towards a Discourse-Pragmatic Model of Computer-Mediated Communication. In: Deborah Tannen \& Anne Marie Trester (eds.) Discourse 2.0: Language and New Media. Washington, DC: Georgetown University Press, pp. 155-166.

Walton, Shana \& Jaffe, Alexandra 2011. "Stuff White People Like": Stance, Class, Race, and Internet Commentary. In: Crispin Thurlow \& Kristine Mroczek (eds.) Digital Discourse: Language in the New Media. New York: Oxford University Press, pp. 199-219. 
Wilson, Jason \& Fuller, Glen \& McCrea, Christian 2013. Editorial: Troll Theory? The Fibreculture Journal, Vol. 22, pp. 1-14. Available at http://twentytwo. fibreculturejournal.org/, last accessed on July 3, 2017.

Zwagerman, Sean 2010. Wit's End: Women's Humor as Rhetorical and Performative Strategy. Pittsburgh: University of Pittsburgh Press. 


\title{
RIDDLES AND HUMOUR
}

\author{
Annikki Kaivola-Bregenhøj \\ University of Turku, Finland \\ e-mail: annikki.bregenhoj@elisanet.fi
}

\begin{abstract}
Why do riddles amuse their users and listeners? A riddle exists in a performance context in which all the participants want to enjoy the game. The situation simultaneously involves both entertainment and humiliation, because riddles are intended to mislead the listener: "right" answers are often "wrong". In the Finnish folk tradition, the unsuccessful riddlee could be sent to Hymylä, which was a fictitious topsy-turvy world. It was frightening and humiliating for the riddlee to be sent there. Riddling demands that the riddlee learns to tolerate being laughed at.
\end{abstract}

Keywords: humour, Hymylä, joking question, laughter, performance, riddle, riddling, sexual riddle, situation, true riddle

In this article I examine riddles, old and new, and riddling material in the Folklore Archives of the Finnish Literature Society. In 1967 the archives wanted to expand their riddle collections and, accordingly, asked people to submit both riddles and information about riddling situations at which they had been present. This was the first enquiry dealing solely with riddles, and it was published in the Folklore Archives' periodical Kansantieto (Folk Knowledge). Some 30,000 riddle variants were submitted, along with 68 reports of contexts. Some of these were only brief, but there were also some detailed descriptions of social occasions on which riddles had been posed. The descriptions had one thing in common: the riddling had been fun and it had produced plenty of laughs. "Everyone had fun" or someone was "quick-witted and always game for some humour and little digs" (SKS KRA: Elsa Jaatinen Jyväskylä AK 6:139.1967). The enquiry was made just in time, because it was then still possible to find people with personal memories of riddling, a genre fast vanishing in the changing society. It jogged their memories by giving the opening words of riddles, which readers then completed and sent to the Folklore Archives. Writers did not, however, specify what made them laugh, but then again, they were not asked to do so.

In an attempt to find out why riddles amused people, I analyse them from different eras. I concentrate on verbal tradition and in this article omit, for 
example, droodles and other non-oral riddles in which a humorous situation "is not created, described and expressed by a text" (Raskin 1985: 46). Droodles, for example, which have been widely researched (Price 1953; Klintberg 1978; Preston 1982; Roemer 1982; Voolaid 2009), require an ability to read the image, but the riddlee may need to stop and consider for a moment the right answer to the expression represented by the image. By contrast, oral riddles require a rapid ability to interpret the image correctly. Why does word play in riddles make people laugh? Are riddles entertaining because success alternates with failure? Is the laughter the result of nervous tension: what if my "correct" answer does not satisfy the riddler? Who holds the upper hand? When reading dozens and even hundreds of riddle variants, the researcher begins to have some idea of the fun and humour inherent in riddles.

A riddle detached from its context does not necessarily make the researcher laugh. It acquires a life of its own in performance. When I read so-called "true riddles" and present-day so-called "joking questions", I search for hints and keys to the comic element and humour of riddles in the context information found in the descriptions. I reflect on the riddler's attitude, and the power he or she wields when posing the question. If humour is a combination of violating a norm, surprise, and hyperbole (Bregenhøj 1988: 181), then how are these characteristics manifested in riddles? When something amuses us, we enjoy what "clashes with our mental patterns and expectations" (Morreall 1989: 1).

Riddles are expressions comprising a question image and an answer. For example: (\#1) "It lives from the beginning of the world to the end of the world but is never five weeks old. Answer: The moon". The image here claims something that, viewed rationally, is impossible. The answer is hidden in the question, which simultaneously both misleads and provides a hint to the right answer. A person skilled in the riddling tradition has in his or her competence a vocabulary characteristic of the genre, a stock of metaphors, and the ability to construct contrasting, antithetical, and paradoxical images. They are also familiar with typical structures, and above all the art of combining these elements of the language of riddles according to the semantic codes peculiar to the genre (Kaivola-Bregenhøj 2001: 130).

Asking riddles - riddling - was mostly a winter leisure pursuit, when people of the house got together to do the handwork and repairs necessary in a selfsufficient household. At the same time, they could tell stories, sing songs, or ask riddles. These situations were important for the transmission of oral tradition in general, for monotonous work was made easier by entertainment in the form of oral folklore. Summer in the farming community was, on the contrary, a very busy time with plenty of work in the fields and less time to have fun. 
Riddling is an exchange of words in which people are deliberately misled because the "right" answer is sometimes completely unexpected. Riddling is not, however, a general knowledge quiz, because the "correct" answer may be "wrong", in other words, arbitrary. Riddling is a social occasion that values entertainment, quick-wittedness, getting the answer right, humiliation and its tolerance. As Akíntúnde Akínyẹmí points out, while speaking of riddles, "the performer and audience often derive equal pleasure and entertainment from participating" (Akínyẹmí 2015: 84). The audience is never passive. For the riddler and the audience the game would be boring if all riddles were easy to guess.

\section{TWO TYPES OF RIDDLES: TRUE RIDDLES AND JOKING QUESTIONS}

In this article I deal with only two types of riddles. One is the true riddle, in which the question contains not only a misleading element but also a hint at the answer, as in the riddle about the moon (\#1). The person who answers the riddlee - is familiar with the genre and knows that the image would not immediately reveal the answer. He or she either has to spot the link between what is misleading and what is true, or he or she already knows the answer. Spotting the semantic fit between the riddle image and the answer is a pleasurable experience.

True riddle images use many different formulas. Some of the formulas and metaphors are international, but each language and cultural area also has models of expression of its own. In Finland the language of riddles bears traces of the metre of archaic Finnish epic poetry. Alliteration is more frequent, whereas rhymes are less common. Only a few true riddles have been preserved. An example with one of the popular formulas is: (\#2) "Mindless, tongueless, tells the truth to all. Answer: A steelyard".

True riddles and joking questions are products of such different eras that they are not often posed on the same occasion. True, the children I met in a Helsinki school in 1973 knew both traditional riddles, such as (\#3) "A black man with a stub nose. Answer: A pot", and new joking questions such as (\#4) "It's blue and eats hay in a field. Answer: A cow wearing a tracksuit" (Kaivola-Bregenh øj 1974: 107-108). Joking questions are contemporary riddles that have nothing in common with the old riddles apart from a question and an unexpected answer.

Riddles abound in seemingly impossible things (Virtanen 1960: 160) that people either have to guess or know beforehand. Ambiguity and incongruity that would be avoided in normal speech are totally acceptable in riddles. As has been 
pointed out, everyone likes the unusual linking of subtle images (Barley 1974: 149). Giving the right answer has been regarded as indicating that the riddler realises that the language is ambiguous. He or she has learnt the cultural art of how to manipulate ambiguity (Haring 1985: 166).

Riddles both hide and reveal their object. They lead the listener astray and seek to provide a new perspective on something familiar to all (Pepicello 1989: 210). A good example of morphological ambiguity is a trick question: (\#5) "What's black and white and red all over? Answer: A newspaper", in which there is a play of homophony between a simple lexical item (the adjective red) and a verb plus its past participle morpheme (read). The possibility of being led astray is always present, and it both perplexes and amuses. The fact that the riddlee grasps the connection between the question and the answer and comes up with the correct answer may also be part of the fun. Riddling teaches people to take the right attitude to the comic element, and there is humour to be found in a form of interaction in which one party holds the upper hand.

Riddling is a promise of fun. It serves as a frame in which all have to be alert and to accept what is coming with a sense of humour. The rules are familiar to all, and people welcome a chance to have fun with others and make the everyday chores easier. Riddling means permission to have some funny exchange of words, even though excessive laughter might otherwise be frowned upon. When Victor Raskin (1985: 47) says, that "[i]deally, a linguistic theory of humour should determine and formulate the necessary and sufficient linguistic conditions for the text to be funny", riddles are an exception. The context - riddling - makes the text funny even though, out of context, it would not be.

\section{SEXUAL RIDDLES}

Sexual riddles may serve as an example of the strange humour of riddles. Sexual riddles are among the most outspoken expressions of folk eroticism. The use of sexual vocabulary is, however, rare in riddles, unlike in other forms of erotic folklore. Riddling in the home is often a family occasion, and in that case the language has to be fit for children's ears.

We do have some information on the contexts in which traditional sexual riddles were used. Among groups of young people this lore has always clearly served the function of raising the erotic temperature. In the farming community there were some jobs done by the young people of the village together, and these situations provided a setting for the transmission of oral tradition. The verbal pranks of a Finnish working community are described as follows: 
In the autumn the malt was sweetened in a malt sauna and spirits were brewed. Usually the work was done by the young girls from the farm. It was a laborious job, because it had to be watched over day and night. The time nevertheless passed quickly, because as soon as the boys caught a whiff of the malt, they sought out the girls and helped them pass the time by dreaming up all sorts of pranks. One popular entertainment was posing riddles for the girls to answer. And the boys were indeed sharp, for many riddles led one's thoughts to something that would make a girl blush and giggle, whereas the object to be guessed might well have been something as innocent as a tobacco pipe or a spoon, or such legitimate pursuits as weaving, spinning or father eating lingonberry porridge out of a bowl in mother's lap. Other riddles were less 'risky'. (Wessman 1949: VII)

Sexual riddles were particularly popular with men. Some of the reports describe riddling among groups of men working in the forests. "We spent the nights in the village sauna out in the forest. There the men would sometimes feel inspired to pose riddles, and then the riddles were ones to do with sexual things" (SKS KRA: Eino A. Hyytinen AK 4:292.1967).

On such occasions it was possible to be amused and laugh openly at the sexual humour, which was sometimes most explicit.

Some folklore collectors mention that women were in the habit of interrupting a game or changing the topic of conversation as soon as anyone began asking sexual riddles. Women's chastity is also underlined: "The farm hands and day labourers were bolder at asking obscener ones, whereas the mothers and serving girls were more respectable" (SKS KRA: Olga Hirvonen AK 3:369.1967).

This information on the use of riddles dates from the extensive collection of Finnish riddles compiled in 1967, and throws light on the situation in the early decades of the twentieth century. But are the details of women's attitudes necessarily as straightforward as this? What was the limit to the presentation of sexual lore? I could ask if women hid the fact that the humour amused them. I am sure they did, because some folklore collectors found that women were as bold as men in posing suggestive riddles. The following quotation, though brief, from an answer given to a Finnish riddle collector, is typical: "The riddles are from the Rajala shoe factory at Kankaanpää, where a [female] worker called Aili Kivelä put them to the young men working alongside her" (SKS KRA: Olavi Määttä AK 12:64.1967). The teasing between men and women is enhanced here by the fact that the riddler is older than her colleagues. But even young girls might ask sexual riddles, giggling and blushing or "turning their faces away as they hand a paper bearing a suggestive text" (Wessman 1949: VII). 
It has quite rightly been pointed out that bashful publishers are responsible for creating the highly proper, yet misleading, picture of folklore as something that is almost antiseptically devoid of sensuality (Launonen 1966: 374). One rare exception is Finnish clergyman Christfrid Ganander, who published the first collection of Finnish riddles, titled Aenigmata Fennica, as early as 1783. Ganander appreciated the value of living tradition and did not censor his publication. The sexual riddle is a living tradition, and one still in use: sexual riddles and jokes are not merely a past form of entertainment, since they are continuously favoured by both adults and children. Mixed groups of adults have from time immemorial cultivated open and risqué sexual humour, so why not sexual riddles too, which, being ambiguous, are exciting. We do, however, have very few descriptions and facts about what people talked about when they got together, and about the type of language permissible on a given occasion.

The riddles in today's Finnish children's tradition may be outspoken, and their humour is often founded on verbal word play. In the African Yorùbá community, sex and sexual organs are not directly mentioned, but they may be indicated euphemistically, and "riddles underscore the importance of sex and sexual organs and allow us to accept their inevitable presence" (Akínyẹmí 2015: 86). When delicate matters are dressed in humour, youngsters learn to speak of them in a way that is socially acceptable. The following examples (here just in English) are deemed suitable for children and young adults: (\#7) "The Olóféèrè bird on the road to Ìbàdàn. That laid two eggs, and placed its chin on them. Answer: Male genital organs - the penis and testicles", and (\#8) "Two bẹnbẹ drums, resting against a baobao tree. Answer: A woman's breasts" (ibid.: 86-87).

Erotic teasing and laughter are typical of the riddle tradition, but is this really humour? There could be several answers, because expressions interpreted as humour are culture-specific and always tied to the performance.

Erotic joking or the generation of an erotic charge is easy with the help of short joking questions. I quote two American sexual jokes analysed by Pertti J. Anttonen (2000): (\#9) "What's the difference between a beer and a woman? Answer: Beer is wet all the time"; and (\#10) "What's the difference between a Coke and a Man? Answer: Coke comes in a can, but a man comes in your mouth".

Anttonen (2000: 246-256) demonstrates by a close analysis of jokes and their performance contexts that these two sexual jokes were, in an interactive situation observed by him, the last straw that caused the disintegration of a relationship. The words "beer", "wet", "Coke", and "your mouth" became fully charged with totally unforeseen meanings to which the man and the woman gave different interpretations in keeping with their own frame of mind. In telling the jokes, the man intended to be amusing, to provide some light relief, and 
to demonstrate that he wanted the relationship to continue. By contrast, the woman found the key words offensive, and the man's feeble attempt at trying to make her laugh made her all the more determined to put an end to the affair.

The true meaning of joking is only revealed in context, which demonstrates how differently people may interpret the same sexual riddles. One may be offended by something that another regards as liberating humour.

\section{A CHANGING TRADITION}

The riddle tradition began to change in the 1960s. The imagery of the old riddles in Finland was drawn from the agrarian domain, and a uniform culture. Both the questions and the answers therefore concentrated on life on the farm, women's and men's jobs, domestic animals, and just occasionally the forest and vicinity beyond the farmyard. The agrarian way of life became alien with the development of industrialisation, urbanisation, and changes in working life.

Spinning, churning, seine fishing and ploughing became strange work; while things like a still, pothooks, a baker's peel, a spit, carding combs, a sieve, a quern, a quill pen, the runners of a sleigh, a knapsack, a scythe, and millstones became strange articles. Central heating and electric lighting took the place of the fire burning in the oven or the forked stick for holding fir torches, not to speak of innumerable other changes: it was no longer taken for granted that there were lice in people's hair, porridge was eaten from the same bowl, a pig no longer entered the living room, everyone learned to write. (Virtanen 1977: 77-78)

As country folk moved into towns in search of work, old riddles lost their natural context and people no longer understood them. The imagery ceased to amuse them. The complex language of true riddles was also removed from everyday speech.

"The riddle joke is one of the most common joking forms today," says Dorothy Noyes (1997: 731). These riddles are, in fact, a fast-renewing tradition among children and adults alike. The entertainment of riddle jokes may involve attitudes towards important and serious aspects of life, such as religion, politics, work or sex (Brunvand 1970: 128). Elephant jokes have been among the most popular jokes both in the USA and Finland. In the spring of 1964, my fellow student Ulla Lipponen noted down elephant jokes in the student café at Helsinki University, where we used to sit. These riddles described the colour of an elephant, the clothes it was wearing or its adventures in an urban milieu. For example: (\#11) "Why is the elephant wrinkly? Answer: Because no one strokes 
it". Although elephants later went out of fashion in the tradition of young adults, they were still a living part of children's lore in the mid-1980s. In Estonia this type of joking question is still the most popular one (Voolaid 2009: 144).

Another popular joking question is the dumb-blonde jokes, the sexist tone of which does not leave the reader of the joke columns cold. In the autumn of 1993, a boy in my daughter's class entertained 14-year-old girls during the domestic science class with dumb blonde jokes like these: (\#12) "Why did God create blondes? Answer: Because apes never learnt to fetch beer from the fridge"; (\#13) "Why did God create brunettes? Answer: Because the blondes didn't learn to fetch beer from the fridge either"; and (\#14) "How do you reduce a blonde's brains to the size of a pea? Answer: By blowing them up".

A certain theme may be wildly popular while this type of question is in fashion, but it is soon exhausted and the riddles no longer appeal. This rule does not, however, apply to dumb blonde jokes, the reason for whose popularity and viability can only be guessed. There are long strings of dumb blonde jokes circulating on the Internet (Kaivola-Bregenhøj 2001: 58-59). In 1997 Ulla Lipponen was given 50 pages containing some 2,000 joking questions on this theme, which a friend had printed from the Internet, at least some of them variations on the old models (discussion with Ulla Lipponen 2000). And whereas the blonde was still mainly just dumb in the schoolgirl tradition of the early 1990s, today there are also numerous jokes on the Internet telling of her promiscuity, such as (\#15) "Why did the blonde like the car with a sunroof? Answer: More leg-room" (see www.jokebuddha.com), or (\#16) "What's the difference between a blonde and a Porsche? Answer: You don't lend the Porsche out to your friend" (www. jokebuddha.com.Porsche). In any case, the dumb blonde is always a woman and there seems to be no limit to her stupidity. Blonde jokes are very popular also in Estonia, where some are viewed even from a female perspective, for example: (\#17) "Why are blonde jokes so short? Answer: So that men can understand them" (discussion with Piret Voolaid 25.6.2015).

On the one hand, the imagery of the joking question is international, yet, on the other, strictly local. Since we Finns are not familiar with the demography and stereotypes in the USA, the disparaging jokes of the 1960s about poor, dirty Poles do not address us. Some good examples of ethnic joking questions are: (\#18) "What do you get if you pour hot water on a Polack? Answer: Instant shit"; and (\#19) "Do you know why flies have wings? Answer: To beat the Polacks to the garbage" (Davies 1990: 85). The target for ethnic riddles was, in the USA, most often the Polish immigrants. These jokes were often crude, and either the Poles were depicted as simpletons who did everything wrong, or the point of the jest was aimed at their dirtiness or their lowly position in society. Sometimes dirt and stupidity are linked together in ethnic jokes. Of course, there is no 
proof that the Poles are any less hygienic than their fellow citizens in America. It should, on the other hand, be remembered that jokes are not realistic, and nor are these ethnic jokes (Raskin 1985: 205; Davies 1998: 50; 1990: 89, 308). It has subsequently been argued that the Poles acted as a channel for letting off the aggression that could not be openly aimed at the Afro-Americans (Dundes 1971: 186-203). But Christie Davies (1998: 167) thinks - however - that Alan Dundes suggested this erroneously. Many scholarly dissertations based on tradition in oral circulation show that jokes of blacks are both numerous and popular in the United States. A small number of them concern just published collections of jokes.

The humour of ethnic joking questions relies on the listeners' familiarity with the butt of the joke. Their strange humour remains an enigma unless the listener has sufficient context information. The leavening agent of joking questions is the "stupidity script" placing rational, non-stupid "us" side-by-side with stupid, irrational "them". The main function of these riddles is indeed to make fun of "them" and demonstrate "our" superiority (Voolaid 2011: 31-32). Many jokes that raise a laugh elsewhere in the world fall dead in Finland because the cultural context is alien to us. But we do make jokes at the expense of minorities so long as the object is familiar. The expressive models of riddle jokes are easy to reproduce as compared to the language and metaphors of old riddles. Jokes are easy to update so long as people remember that the answer must always be comic or infuriating.

The joking tradition is not, however, just innocent entertainment; both children and adults use it as a means of addressing various aspects of life, such as major disasters. The first wave of worldwide disaster jokes concerned the 1968 war and famine in Biafra. Some of these international jokes also found their way to Finland, for instance: (\#20) "What's the difference between a Biafran child and a ping-pong ball? Answer: Five grams". In the 1980s, I was told some Biafra jokes by some schoolchildren who had dropped in on one of my lectures. In Sweden, many schoolchildren regarded the jokes as sick, yet the jokes spread all the same. It has, however, been stressed that disaster and racist jokes are not always intended to make people laugh (conversation with Ulla Lipponen 2010). There is nothing new about even gross joking about topics that are painful, politically sensitive or have to do with religion. Alan Dundes and Thomas Hauschild (1983: 249) wrote about Auschwitz jokes jeering at the mass murder of the Jews and said, "Nothing is so sacred, so taboo, or so disgusting that it cannot be the subject of humour. Quite the contrary..." One of the strategies of joking is to topple people uppermost in the social hierarchy, such as priests, academics, experienced politicians or people such as doctors in prestigious professions (Brunvand 1970: 129). 
Humour has also been used as a means of addressing politically sensitive issues that could not have been written about in the media. Piret Voolaid (2010: 63, 73-76) has studied what are known as "abbreviation riddles", which are in most cases acronyms. They are both witty and humorous, and their hidden meaning is often either political or sexual. For example, the FBI (Federal Bureau of Investigation) can get the interpretation "Female Body Inspection". In Estonia the main bulk of "alternative abbreviation interpretations" has been collected by some unsanctioned collectors, who understood the importance of storing the material which under the totalitarian Soviet regime was totally ignored. These abbreviations have a strong political flavour; for example, the abbreviation SSSR (Soyuz Sovetskikh Sotsialisticheskikh Respublik - Union of Soviet Socialist Republics) has several different interpretations, the most famous of which in Estonian is "Siberi sead situvad reas", in English "Siberian swine shitting in rows". The top ten of these abbreviations are connected with the Soviet state names, but there are also many interpretations related to Joseph Stalin, like "Stalin sõitis seaga ratsa", in English "Stalin rode on a pig". Christie Davies (1998: 77) points out that "[t]he people portrayed as stupid in Eastern European jokes tended to be the leaders of the Communist Party", like (\#21) "Why do Czech militiamen go round in groups of three? Answer: One can read, one can write, and the third is keeping an eye on the two intellectuals"; or (\#22) "Why was Grechko made a Marshal of the Soviet Union? Answer: Because he was too stupid to be a General".

The majority of the abbreviation riddle jokes faded away after Estonia regained independence in 1991. It was now possible to criticise politicians and the authorities publicly in the media. Where people are free to discuss and criticise politicians, political jokes are less common in oral tradition (Davies 1998: 174-175). But in Estonia the corruption of politicians might still be criticised by means of abbreviation riddles. In school lore, such interpretations have continued; for example: USA (United States of America) as "Uskumatult suur armastus", in English "Unbelievably big love" (Voolaid 2010: 79-80).

Some joking questions have been attached to politics and politicians in Finland, but they are usually language-specific. Some decades ago the Finns made jokes at the expense of their then prime minister. Because Finnish is not, unlike English, an Indo-European language, the English spoken by the Finns is often clumsy. The prime minister in question had on one of his overseas tours visited a zoo and had seen the word "dangerous" on the cages. Hence it gradually dawned on him, or so the story goes, that the word "dangerous" must mean "animal", but he mispronounced it as "tankero". This sparked off a host of "tankero" jokes, all targeted at the mispronunciation of English. In the 1970s the prime minister is said to have asked room service to bring: "tuu tii to töötituu" (two teas to [room] thirty-two) (see https://en.wikipedia.org/wiki/Tankero). 
The popular riddle formula based on similarities and dissimilarities is easy to apply to politics, too: (\#23) "What's the difference between politics and a poker player? Answer: For the latter, deception is just a game" (see https://www.vitsit. biz/vitsit/politiikkavitsit). The Internet abounds in political jokes, and in my article I can only speak of jokes in question form as riddles.

\section{“HYMYLÄ": PUNISHING THE UNLUCKY RIDDLEE}

The riddle types I have been discussing have one thing in common. A riddle is conceived as a question to which an answer has to be found. The imagery of old riddles was drawn from the agrarian domain and its uniform culture. Because people all led similar lives, it could be assumed that the riddlers would all be familiar with the empirical world from which the tradition drew its images. People thought it comic and risible if someone could not answer a question made up of familiar elements. Yet, however familiar the imagery was, an unexpected angle as in a riddle could be a surprise. In Finland the unsuccessful riddlee - the person who could not answer the riddle - could be punished. $\mathrm{He}$ or she was sent to a place called Hymylä (variant names such as Himola and Hölmölä are found), which could translate as Smileland. It was a fictitious, topsy-turvy world. The oldest known account of the Hymylä game appeared in Christfrid Ganander's Aenigmata Fennica (1783), and many such Hymylä incidents were mentioned in Finnish folk poetry in the early decades of the nineteenth century. Other scattered accounts of this folk-like farce are found in the folklore archives, and at the time of the riddle collection in 1967 the Hymylä punishment was still recalled.

There were three main episodes in the drama:

1. The departure for Hymylä, consisting of a proper outfit for the traveller;

2. The visit to Hymylä, usually being sent outside for a while or to the next room. Then the traveller was taken back in;

3 . The account of the journey.

Before the game began, the participants had agreed on how many riddles could be answered incorrectly before a riddlee was sent off to Hymylä. Usually the number was three. As soon as someone had given three wrong answers, the Hymylä episode followed. There were two opposing protagonists in the drama: the incompetent riddlee and the group putting the sentence into practice. Symbolically the unlucky riddlee was excluded from the group. Departure for Hymylä might have taken place to the accompaniment of a jingle, as one informant writes: "If you didn't know [the answers], you got sent to Hymylä. They said, 'Hush, hush to Hymylä, for not knowing even that"' ("Hyys, hyys, Hymylään! 
kun et sitäkään tiedä”) (SKS KRA: Taimi Pitkämäki AK 14:1.1967). A prelude was sometimes added to the trip to Hymylä. Participants at the riddling session would find ridiculous garments for the traveller: "Thus the girl was soon ready for Hölmölä. Now she was dressed in the oddest, 'billygoat' fashion, and was sent out of the living room" (ibid.).

On the victim's return to the group it was often expected that an account of the visit should be presented, reporting on the reception and treatment afforded to the traveller at the destination. However, the opposite could take place, so that members of the group would pretend to be the people of Hymylä, who would talk about the luckless traveller and amuse the rest of the group. The record continues:

Then began the fantasising about how she would be received in Hölmölä. Someone tells that Hölmölä's dogs are barking, whereat the children go to see what they are barking at, and they bring back the news that a ragged old woman is coming who's drawn by a cat and the sleigh's upside-down. In addition, she has horns on her head. Hölmölä's housewife takes fright just as she is salting her butter, and in her fright she throws ashes instead of salt in her butter, then overturns the milk pail into the hearth and lights the fire with her church silk. The daughter of the house turns a slops bucket over the stranger's eyes. When the latter asks to be allowed to wash, she is given a tar bucket and ordered to dry herself with bedding straw. Then she is asked about news from the world. When she doesn't know what else to say apart from those unsolved riddles, the poor creature, the likes of her, is pitied and given chaff mixed with buttermilk, the heads of last year's herrings and the holes of ring bread for her food. (Virtanen 1977: 81)

The humour in the description springs from the fact that the familiar farm milieu is turned upside-down and the unlucky riddlee is showered with scorn and disgusting or fanciful things to eat or to wash with. One amusing detail is the question about the world news, and it speaks of a time when news was predominantly oral and local. Obviously Hymylä is a topsy-turvy world in which all the customs and practices of our world are reversed or wrongly executed.

The description of Hymylä was comic because it was so exaggerated and its purpose was to amuse those who had managed to give the right answers. Hymylä represented popular ridicule in its most typical form. The grotesque jesting gave rise to hilarity in the group of players. At the same time people might stress that "we did our best to remember, to make sure we didn't get sent to Himola, because that was a disgrace", or "people were loath to join in the riddling for fear of being disgraced" (Kaivola-Bregenhøj 2001). Although it was only a game, the trip to Hymylä could cause anxiety. "The trip to Hymylä was so frightening that it was liable, even later at night, to disturb sleep if one 
had received that rebuking in the evening" (SKS KRA: HAKS 769.1927). The reverse of humour and comedy was constantly present, because anyone could, at any moment, be made to look stupid.

The role-exchange as such is not a device of the Finnish Hymylä game alone, for it is known internationally as a form of popular jesting in, for example, Estonian and Scandinavian poetry (Kaivola-Bregenhøj 2001: 114-116). In Estonia there are - contrary to the tradition in Finland - real geographical places "where riddlees were sent after the answer - for example Rasina and Üikkala and Uikala" (Voolaid 2011: 28).

Hymylä was an extension of true riddles, now mostly forgotten. Today's joking questions do not require a performing situation. They are slipped into the general discourse and may be posed either as a series or individually. The aim of these kinds of riddle jokes is to surprise and trick the riddlee and force him or her to admit they cannot find the answer. No wonder, since it is impossible for a novice to guess the answer. Once the guesser has become more familiar with the genre, the semantic construction may open up to the riddlee. Riddle jokes may incorporate the idea put forward by Alan Dundes, who has said that one of folklore's "most important functions is permitting action that is usually not approved" (Dundes 1965: 277). In decent language there are words that should not be used, but if hidden in a joking question, their vulgarity has a comic element.

\section{RIDDLE HUMOUR}

Why were riddles posed, and what did they give to the community? Both true riddles and joking questions were a way of learning social mores: in addition to having fun and a good laugh together, people had to learn to tolerate being misled or bluffed without getting offended. There were several different functions simultaneously at work in a riddling situation, only some of which are perhaps immediately evident. Riddling provides a form of entertainment, but at the same time the communication fosters a sense of affinity among those taking part, brings cultural metaphors and terminology, and expresses the values and norms of the community. The laughter surrounding riddles was of many kinds, from questioning to relief and from amusement to jeering. Not only could laughter spring from humour but also from the gathering and the conviviality that it brought about. Taking turns has always been an important part of riddling, because it ensures that the game continues. People's sense of humour differed, but riddling gave it collective limits and demonstrated what was permissible and what was not. 
Riddles open a window on the ambiguity of language and tradition. The humour in riddles is a special mixture of creative or innovative word play, making the familiar seem unfamiliar, pulling the rug from under the riddlee's feet by violating the norm, wielding power, and discovering comic elements even in places where no one thought to look for them.

\section{NOTES}

1 Finnish is pronounced more or less as it is written. Some speakers have difficulty with voiced plosives, such as [d] and [g], because these do not occur in spoken Finnish.

\section{ARCHIVAL SOURCES}

$\mathrm{AK}=$ Arvoituskilpakeruu (Collecting riddles by the SKS through tradition competitions). The Folklore Archives, Finnish Literature Society, 1967.

HAKS = Hämeenlinnan alakouluseminaari (Collections of the Hämeenlinna Junior School Seminary).

SKS KRA = Suomalaisen Kirjallisuuden Seura, Kansanrunousarkisto (Collections of the Folklore Archives of the Finnish Literature Society).

Ulla Lipponen = Ulla Lipposen keräelmät 5811-5812. 1987 (archival materials collected by Ulla Lipponen).

\section{REFERENCES}

Akínyẹmí, Akíntúndé 2015. Orature and Yorùbá Riddles. New York: Palgrave Macmillan. DOI: $10.1057 / 9781137502636$.

Anttonen, Pertti J. 2000. Riddle Jokes in the Negotiation of a Love Relationship. In: Maria Vasenkari \& Pasi Enges \& Anna-Leena Siikala (eds.) Telling, Remembering, Interpreting, Guessing: A Festschrift for prof. Annikki Kaivola-Bregenhøj on her 60th birthday, 1st February 1999. Joensuu: Suomen Kansantietouden Tutkijain Seura, pp. 246-256.

Barley, Nigel F. 1974. Structural Aspects of the Anglo-Saxon Riddle. Semiotica, Vol. 10, No. 2, pp. 143-176. http://dx.doi.org/10.1515/semi.1974.10.2.143.

Bregenhøj, Carsten 1988. Skolbarns humor. [Schoolchildren's Humor.] In: Carsten Bregenhøj \& Marie Johnson (eds.) Blodet droppar, blodet droppar! Skolbarns humor. [Blood Is Dripping, Blood Is Dripping! Schoolchildren's Humor.] Helsingfors: Schildts, pp. 171-210.

Brunvand, Jan Harold 1970. Some Thoughts on the Ethnic-Regional Riddle Jokes. Indiana Folklore, Vol. 3, No. 1, pp. 128-142. Available at https://babel.hathitrust.org/cgi/ pt?id=mdp.39015032118294;view=1up;seq=413, last accessed on July 18, 2017. 
Davies, Christie 1990. Ethnic Humor Around the World: A Comparative Analysis. Bloomington: Indiana University Press.

Davies, Christie 1998. Jokes and Their Relation to Society. Berlin: Mouton de Gruyter. Dundes, Alan 1965. The Study of Folklore. London: Prentice Hall.

Dundes, Alan 1971. A Study of Ethnic Slurs: The Jew and the Polack in the United States. The Journal of American Folklore, Vol. 84, No. 332, pp. 186-203. http:// dx.doi.org/10.2307/538989.

Dundes Alan \& Hauschild, Thomas 1983. Auschwitz Jokes. Western Folklore, Vol. 42, No. 4, pp. 249-260. http://dx.doi.org/10.2307/1499500.

Ganander, Christfrid 1970 [1783]. Aenigmata Fennica: Suomalaiset arvotuxet, Wastausten kansa. [Finnish Riddles with Answers.] Helsinki: Suomalaisen Kirjallisuuden Seura.

Haring, Lee 1985. Malagasy Riddling. Journal of American Folklore, Vol. 98, No. 388, pp.163-190. DOI: 10.2307/540438.

Kaivola-Bregenhøj, Annikki 1974. Perinteellinen ja muuttuva arvoitus. [Traditional and Changing Riddles.] In: Hannu Launonen \& Kirsti Mäkinen (eds.) Folklore tänään. Helsinki: Suomalaisen Kirjallisuuden Seura, pp. 107-126.

Kaivola-Bregenhøj, Annikki 2001. Riddles: Perspectives on the Use, Function and Change in a Folklore Genre. Helsinki: Finnish Literature Society.

Klintberg, Bengt af 1978. Varför har elefanten röda ögön? Om absurda skämtgåtor bland skolbarn. [Why Does the Elephant Have Red Eyes? About Absurd Jokes among Schoolchildren.] In: Bengt af Klintberg. Harens klagan och andra uppsatser om folklig diktning. [The Wailing Rabbit and Other Essays on Folk Poetry.] Stockholm: PAN / Norstedt, pp. 73-95.

Launonen, Hannu 1966. Varas menee aittaan... [The Thief Goes to the Shed...] Suomalainen Suomi, Vol. 6, pp. 374-379.

Morreall, John 1989. Enjoying Incongruity. Humor: International Journal of Humor Research, Vol. 2, No. 1, pp. 1-18. http://dx.doi.org/10.1515/humr.1989.2.1.1.

Noyes, Dorothy 1997. Riddle Joke. In: Thomas A. Green (ed.) Folklore: An Encyclopedia of Beliefs, Customs, Tales, Music, and Art, Vol. 2. Santa Barbara, CA: ABC-CLIO, pp. 730-732.

Pepicello, W. J. 1989. Ambiguity in Verbal and Visual Riddles. Humor: International Journal of Humor Research, Vol. 2, No. 3, pp. 207-215. http://dx.doi.org/10.1515/ humr.1989.2.3.207.

Preston, Michael J. 1982. The English Literal Rebus and the Graphic Riddle Tradition. Western Folklore, Vol. 41, No. 2, pp. 104-138. http://dx.doi.org/10.2307/1499785.

Price, Roger 1953. Droodles. Los Angeles: Simon \& Schuster.

Raskin, Victor 1985. Semantic Mechanism of Humor. Dordrecht: D. Reidel.

Roemer, Danielle M. 1982. In the Eye of the Beholder: A Semiotic Analysis of the Visual Descriptive Riddle. The Journal of American Folklore, Vol. 95, No. 376, pp. 173-199. http://dx.doi.org/10.2307/540717.

Virtanen, Leea 1960. Arvoitus ja sen tehtävä. [Riddles and Their Functions.] In: Jouko Hautala (ed.) Jumin keko: tutkielmia kansanrunoustieteen alalta. [Studies in the Field of Folklore Research.] Helsinki: Suomalaisen Kirjallisuuden Seura, pp. 144-189. 
Virtanen, Leea 1977. On the Function of Riddles. In: Leea Virtanen \& Annikki KaivolaBregenhøj \& Aarre Nyman (eds.) Arvoitukset / Finnish Riddles. Helsinki: Suomalaisen Kirjallisuuden Seura, pp. 77-89.

Virtanen, Leea \& Kaivola-Bregenhøj, Annikki \& Nyman, Aarre (eds.) 1977. Arvoitukset I Finnish Riddles. Suomalaisen Kirjallisuuden Seuran Toimituksia 330. Helsinki: Finnish Literature Society.

Voolaid, Piret 2009. Narrative Droodles as Humorous Miniature Fairy Tales? Acta Ethnographica Hungarica, Vol. 54, No. 1, pp. 143-154. https://doi.org/10.1556/ AEthn.54.2009.1.13.

Voolaid, Piret 2010. Humorous Interpretations of Abbreviations as a Socio-Cultural Phenomenon. Folklore: Electronic Journal of Folklore, Vol. 46, pp. 61-82. http:// dx.doi.org/10.7592/FEJF2010.46.voolaid.

Voolaid, Piret 2011. Eesti mõistatused kui pärimusliik muutuvas kultuurikontekstis. [Estonian Riddles as a Folklore Genre in a Changing Cultural Context.] Dissertationes folklorsticae Universitatis Tartuensis 16. Tartu: Tartu Ülikooli Kirjastus. Available at http://dspace.ut.ee/handle/10062/17528?show=full\&loca le-attribute=en, last accessed on July 18, 2017.

Wessman, V[ilhelm] E[liel] V[iktorinus] (ed.) 1949. Finlands svenska folkdiktning IV: Gåtor. Skrifter utg. av Svenska Litteratursällskapet $i$ Finland 327. [Finnish Swedish Folklore IV: Riddles. Writings Published by the Swedish Literature Society in Finland.] Helsingfors: n.p. 


\section{NEWS IN BRIEF}

\section{SCIENTIFIC SYMPOSIUM ON FOLKLORE HEROES}

On February 24, 2017, the Scientific Research Centre of the Slovene Academy of Sciences and Arts (SRC SASA) in Ljubljana hosted a scientific symposium with a focus on folklore heroes, under the heading $O$ folklornih junakih. The symposium was organised within the project Heroes and Famous Persons in Slovenia and Central Europe (ARRS J6-558; 2013-2017), which involved researches on the theme of famous individuals in history and today - the ones that have had or still have a special status in the community and symbolic imagery. The main questions of the project focused on who, why, and when can become a hero, what heroic characteristics are, why society needs and creates heroes, what society tries to tell people with specific heroes, and for whom those messages are intended. This time these interdisciplinary themes focused on folklore and how folklore heroes are included in national and local history.

The scientific symposium was opened by Dr. Monika Kropej with a discussion on the developments in the perception of the traditions of King Matthew and Peter Klepec. This discussion was followed by the presentation of Dr. Marjetka Golež Kaučič about how folk stories about King Matthew and Lepa Vida (Beautiful Vida) were accepted into the literary canon. Parallels between King Matthew and Prince Marko were discussed by Dr. Božidar Jezernik.

The second section of the symposium included in the discussion also other Slovenian folklore heroes. Dr. Marija Klobčar introduced images of heroism in Pegam and Lambergar, Dr. Saša Babič focused on the manifestations of power in heroes; Dr. Anja Moric and Milan Trobič discussed Peter Klepec and Martin Krpan from the perspective of local and national history, intertwining the stories with (geographic) places and touristic use of those two characters.

The third section of the symposium expanded the concept of the folklore hero to juvenile (literary) heroes for youngsters, which were presented by Dr. Milena Mileva Blažič; Sara Špelec discussed the Slovenian folklorised (movie) hero Kekec; and Dr. Jernej Habjan concluded the conference with an expanded concept of the alpinist as an ideal folklore hero.

A common conclusion of the symposium was that most of the presentations focused on male folklore heroes, which generated the idea for a new scientific symposium dedicated only to female folklore heroes, which are most often neglected or are not even considered in the light of heroism.

The symposium was held in a pleasant environment and opened up new themes and discussions in the research into heroism as well as in folkloristics.

Saša Babič 


\section{FOLKLORE AND THE PUBLIC: ESTONIAN FOLKLORISTS' 12TH WINTER CONFERENCE}

On March 2 and 3, 2017, the 12th Estonian folklorists' winter conference took place in Voore Guest House in Jõgeva County, Estonia. The conference was dedicated to the jubilee of the Department of Folkloristics of the Estonian Literary Museum; its predecessor, the Folklore Sector of the Institute of Language and Literature of the Academy of Sciences of the Estonian SSR had been established in 1947. Conference presentations were given by folklore researchers from Argentina, Estonia, India, Finland, Hungary, Belorussia, and Russia. Two conference days included 19 papers in Estonian, English, and Russian, as well as a film presentation, a concert, and a guided walk in the environs of the conference venue.

The theme of this year's conference was Folklore and the Public, and the speakers co-interpreted these two concepts from rather different angles. One of the topics dealt with in several presentations was the status of folklorists in today's society and in what way they can influence social processes. So, Mari Sarv in her presentation about folklore collections at the service of the public contemplated the changes in the meaning of the collections of the Estonian Folklore Archives. Eda Kalmre's largely autoethnographic presentation asked, on the example of Võnnu Borough, who our history and place names belong to, explaining how little a folklorist can do to influence the ongoing processes. Anu Korb in her presentation about Siberian Estonians and their community pondered how folklorists' interest in Estonian communities in Siberia has influenced their coverage in the media, and to what extent the media has highlighted aspects exotic for homeland Estonians.

Several presentations were dedicated to the observation of beliefs and the public. Mare Kõiva analysed a concrete collection case of belief material, highlighting different strategies used by the collector to obtain information otherwise unavailable to strangers. Mihály Hoppál in his presentation "Some Aspects of Shamanism" focused on shamanistic movements in today's societies. Baburam Saikia's presentation "Belief and Politics in Institutionalized System of Neo-Vaishnava Religion: A Study on the Image of Sattra in Contemporary Assam" focused on the relations between religion and politics in Assam, India, on the example of a concrete new religion.

Several of the speakers expressed interest in modern figurative speech and language use. Anastasiya Astapova in her presentation "Self-Reflexive Metaphors among Refugees in Estonia" analysed figures of speech which help asylum seekers from Belorussia interpret their situation (and also in case their application is refused). Liisi Laineste and Anneli Baran's presentation analysed the role of phraseologisms in hate speech against refugees, based on online comments to a New Year's Eve programme on Estonian television. Liisa Granbom-Herranen in her paper "Proverbs as Part of Common Language" analysed the use of proverbs in the Finnish press. Antti Lindfords' presentation "Performance of Moral Accountability and the Ethics of Satire in Stand-Up Comedy" could also be considered as a part of this group.

Yet another group (although rather diffuse) focused around narrativity. Lyudmila Lobanova's more traditional narrative treatment was dedicated to a concrete narrative 
type - a reindeer legend in modern Komi tradition, and Anatoli Paniukov's theoretical presentation discussed the phenomenon of self-formation in folklore. Anastasiya Fiadotava in her paper "Sharing Humour within a Family in the Digital Age: A Case Study of Belarusian Dyadic Traditions" focused on narration in modern transmedial environment. Two presentations highlighted the therapeutic function of narration. Piret Paal discussed the influence of the media on the expectations of palliative treatment patients as related to their therapy. Bárbara Galarza's paper "The Crazy Man from War in the Context of Folk Therapy: A Case Study of a Storytelling Event from Argentina" discussed the therapeutic function of a concrete narrative type in historical context.

The papers included several fascinating retrospective analyses, which focused either on a moment of time or observed a certain event throughout a longer period of time. For instance, Merili Metsvahi's presentation about the motif of ius primae noctis asked why this particular theme was so widespread in Estonian media and literature of the 1910s-1920s. Mall Hiiemäe discussed the changing role of the folk calendar in the twentieth-century cultural communication in Estonia. Ulla Savolainen in her presentation "Understanding Silence: Interplay of Personal and Public Memories of the Internment in Finland" talked about the internment of German women and children after the Second World War, analysing how the materials published in the media are linked to the reminiscences of those involved. Pille Kippar's autobiographic paper was dedicated to the jubilee of the Department of Folkloristics and provided an overview of folklorists' international relations in the Soviet period.

As the conference was dedicated to the 70th anniversary of the Department of Folkloristics of the Estonian Literary Museum, the first day ended on a festive note. Mare Kõiva, head of the department, spoke about the department's past, present, and future, and handed over letters of appreciation to the former colleagues and permanent contributors.

Katre Kikas 


\section{CULTURAL SCHOLARS GATHERED IN TARTU}

On April 27-29, 2017, cultural scholars gathered at the Estonian Literary Museum and the Estonian National Museum in Tartu for a conference "Across Borders VII: Cultures in Dialogue", which invited scholars to discuss cognitive, social, and cultural aspects in language and literature.

It was the seventh event in the series "Across Borders" (the former ones took place mainly in Poland but also Hungary and Slovakia), which focused, above all, on communication, (ethno)linguistics, and folkloristics. Besides about twenty listeners, 109 scholars from twenty-one countries of Europe, America, and Asia participated in the conference with presentations. The first two days of the conference were hosted by the Estonian Literary Museum and the third one by the Estonian National Museum, where it was organised jointly with the annual conference of the museum.

Plenary presentations were given by prof. Gerard McCann (Great Britain), prof. Mariusz Misztal (Poland), and prof. Mikhail Lotman (Estonia). During three days general panel sessions on language, culture, and literature took place. In cooperation with the Embassy of the Republic of Poland in Tallinn, a photographic exhibition "Stanisław Ignacy Witkiewicz - Witkacy's (1885-1939) metaphysical portraits" was displayed in the big lecture hall at the Estonian Literary Museum.

"Across Borders VII" was organised by the Estonian Literary Museum in cooperation with the Jagiellonian and Krosno universities in Poland, the Centre of Excellence in Estonian Studies, and the Estonian National Museum. The conference was supported by the Estonian Cultural Endowment, the Embassy of the Republic of Poland in Tallinn, the Estonian Academy of Sciences, and the European Regional Development Fund (Centre of Excellence in Estonian Studies).

The programme and abstracts of presentations are available at http://www.folklore. ee/rl/fo/konve/AcrossBorders/2017/index.html.

Liisi Laineste

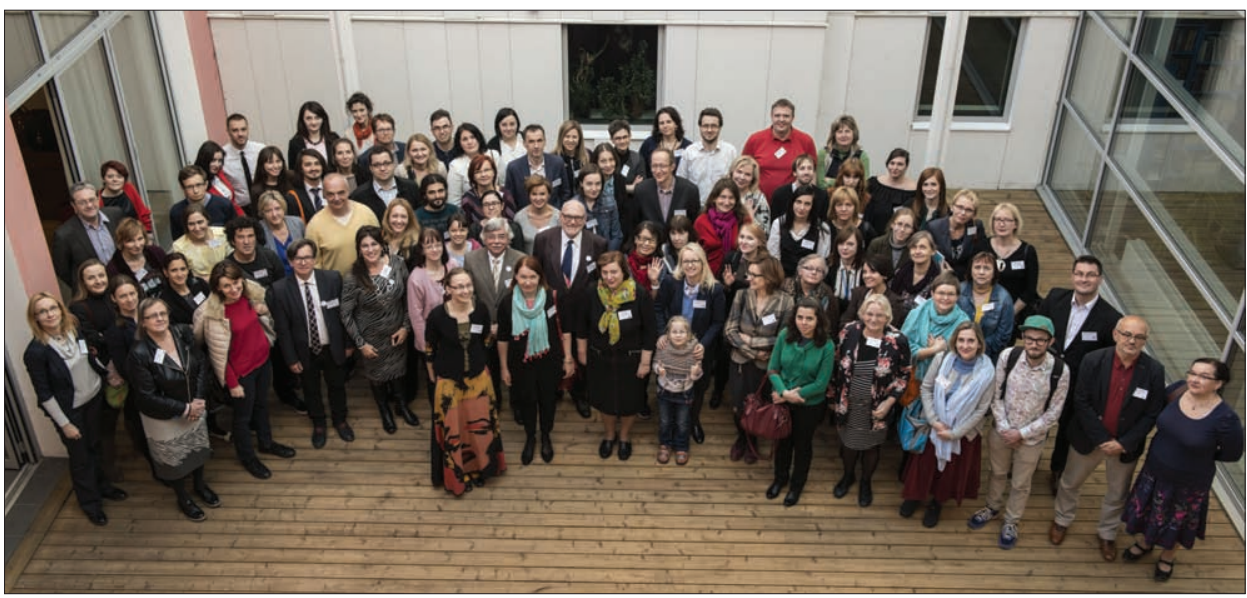

Participants of the conference "Across Borders VII" at the Estonian Literary Museum. In the centre in the foreground Liisi Laineste, main organiser of the conference. Photograph by Alar Madisson 2017. 


\title{
BOOK REVIEW
}

\section{MUTUAL INTERACTION OF TOURISM AND CULTURAL HERITAGE ON THE EXAMPLE OF DRACULA LORE}

\author{
Tuomas Hovi. Finding Heritage Through Fiction in \\ Dracula Tourism. FF Communications 311. Helsinki: \\ Suomalainen Tiedeakademia, 2016. 253 pp.
}

The book focuses on the mutual interaction of tourism and cultural heritage. The author is interested in to what extent we can talk about the positive and negative impacts in the expositions of lore oriented to mainly tourists. To what extent does tourism make the authentic tradition fade away and be replaced by a superficial, stereotyped lore presentation focusing on queer facts and meant merely to satisfy tourists' thirst for thrill? Or should the presentation of the tourist lore experience, on the contrary, value its role in the preservation and display of the characteristic features of local cultural

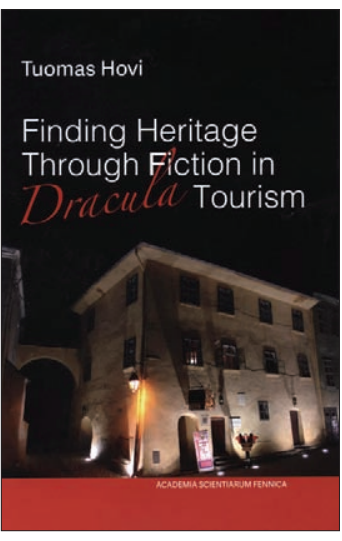
history and folklore? The author's analysis and conclusions are based on his fieldwork carried out in Romania in 2010 and 2011 (for instance, the stories and folklore motifs that guides tell tourism groups) as well as thematic websites of local tourism agencies.

I am afraid that quite a few readers might wonder what else could be said about Dracula in such length as everyone has already heard something about him. However, on second thoughts, even many scholars of culture have to admit that their knowledge is not thorough enough: although they have heard about the blood-thirsty Count Dracula and this character can be encountered in novels and films, it is the tourists that have visited places connected with him that might have a better overview of whether it is a historical or a fictional character, which motifs related to Dracula have been more widely known in folklore, and what has happened to the lore related to him in its place of origin today. As the research reveals, the information presented to tourists is not necessarily superficial; some theme packages offered by tourism agencies last even for a week and introduce, in addition to vampire lore, also the cultural history of the region on a wider scale.

Nevertheless, the author has dedicated plenty of pages in his book to the authenticity of the Dracula lore offered to tourists, involving the aspects of constructed tradition, intertextuality, and hybridisation. In conclusion the author emphasises that Dracularelated tourism should be viewed, above all, as a way of introducing Romanian local lore with the help of Western popular fiction. So it is a constructed tradition based not on local folklore, although it makes use of local folklore (for instance, folktales, folk dances). Here we should also emphasise the author's observation that even the word 'vampire' itself was unknown in older Serbian folklore and therefore most probably imported from elsewhere, although its counterparts in local belief existed already earlier. 
However, the author considers it essential to emphasise that the fact that even if it is constructed tradition, we should not disparage it as something inauthentic or valueless. These traditions are cultural phenomena, which can disclose their own developments and which can play an important role, for instance, in shaping the national or cultural identity. Therefore, as the author maintains, even the Dracula tourism packages organised in connection with Halloween tradition imported from Anglo-American cultural space can offer unique experience to visitors and these experiences can inspire people to tell genuine memorates, which later on are integrated into family lore. The author also holds that even if local people consider Dracula-related souvenirs as inauthentic, nonetheless, for tourists they are authentic tokens of visited places.

The author concludes that although Romanian tourism agencies make use of the Dracula topic to arouse touristic interest, their main aim is to present to the tourist, with the help of this topic, mainly the unique aspects of local culture and history, and highlight, above all, the specificity of the region and its lore.

Reet Hiiemäe 

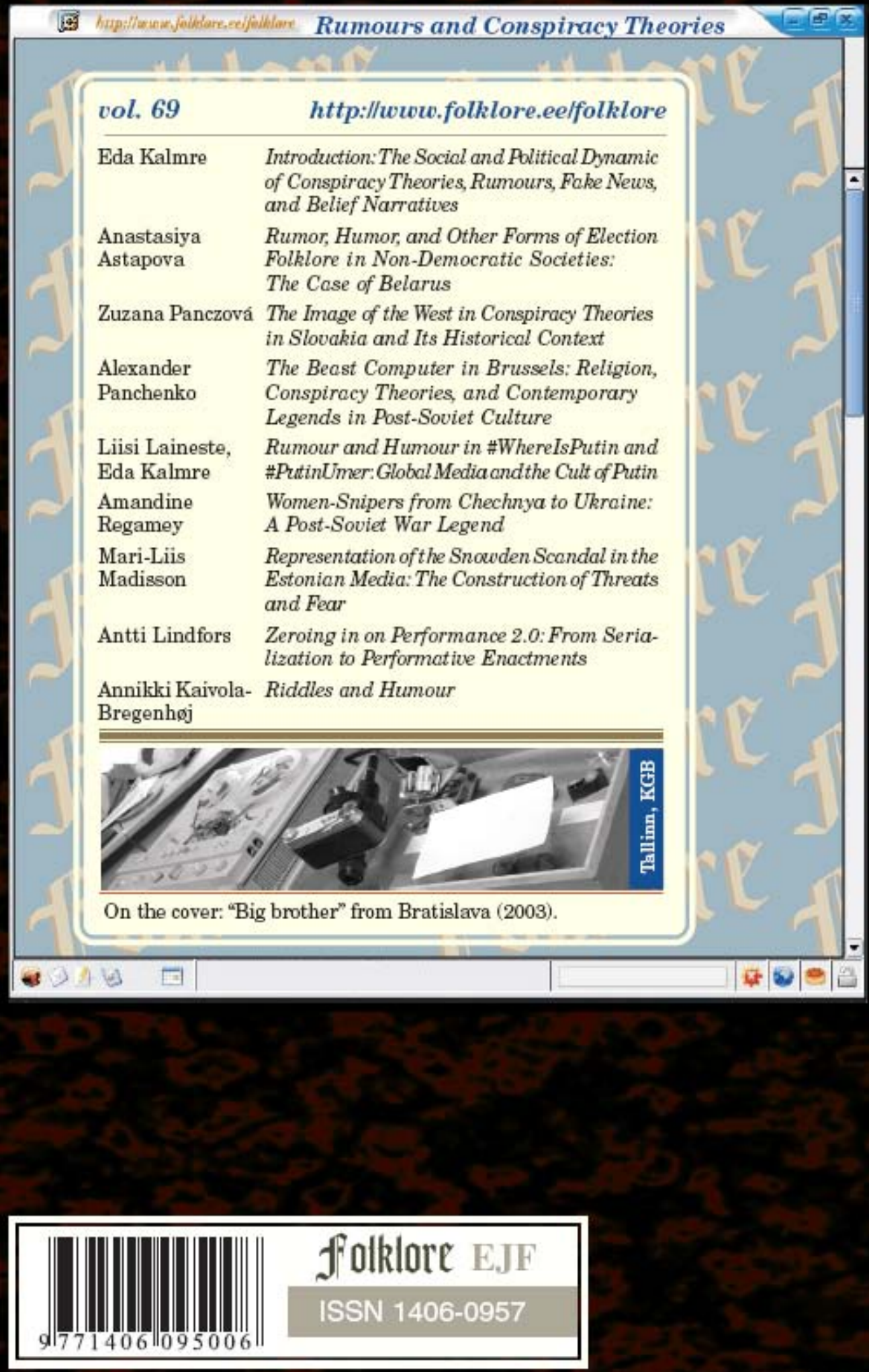